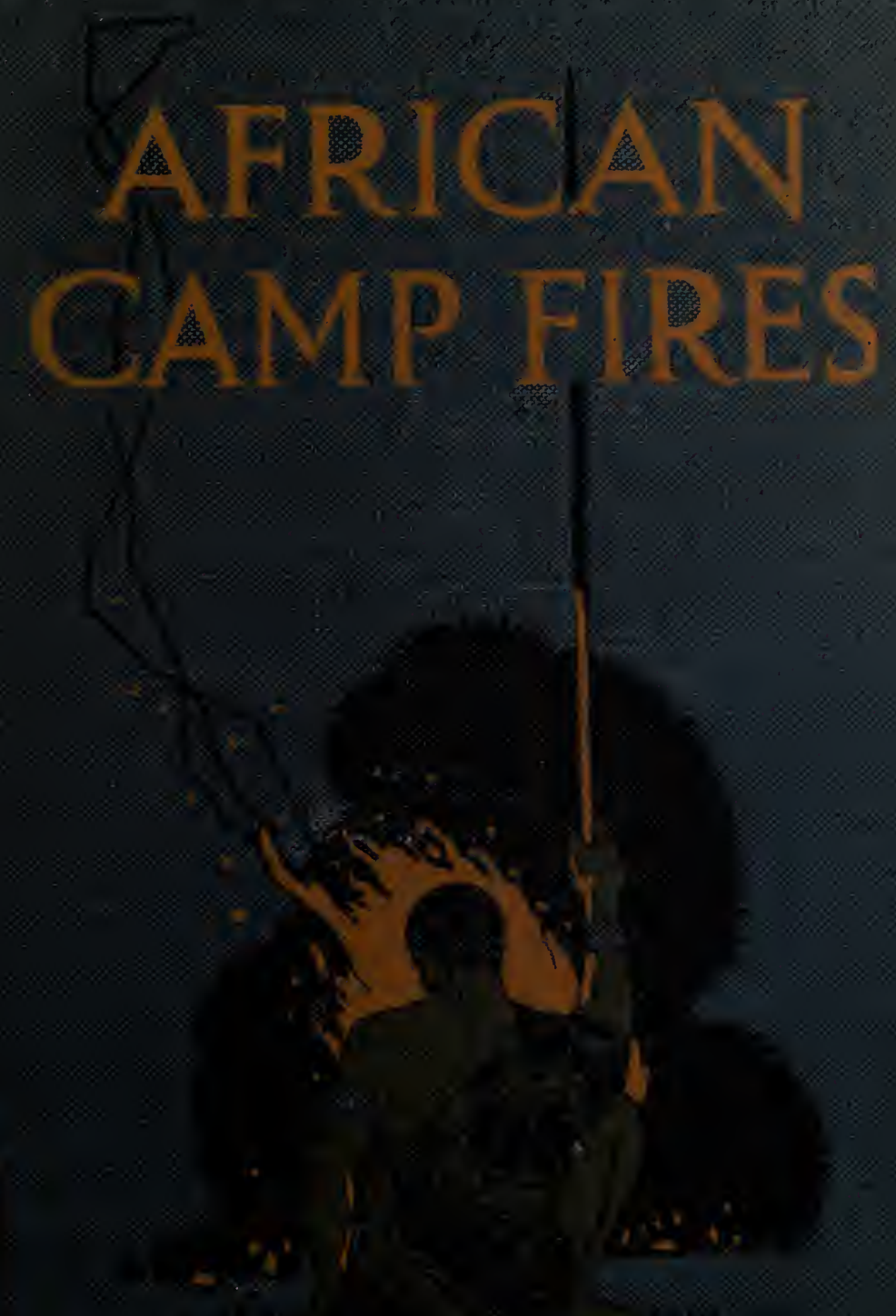

STEWART EDWABDWHITE 


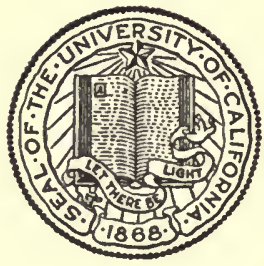

\section{THE LIBRARY} OF

\section{THE UNIVERSITY OF CALIFORNIA LOS ANGELES}


Digitized by the Internet Archive in 2007 with funding from Microsoft Corporation 
AFRICAN CAMP FIRES 


\section{OTHER BOOKS BY THE SAME AUTHOR \\ *}

The Claim Jumpers, The Westerners, The Blazed Trail, Blazed Trail Stories, The Magic Forest, Conjuror's House, The Silent Places, The Forest, The Mountains, Arizona Nights, The Pass, Camp and Trail, The Riverman, The Cabin, The Adventures of Bobby Orde, The Rules of the Game, The Sign at Six, The Land of Footprints (With Samuel Hopkins Adams)

The Mystery 



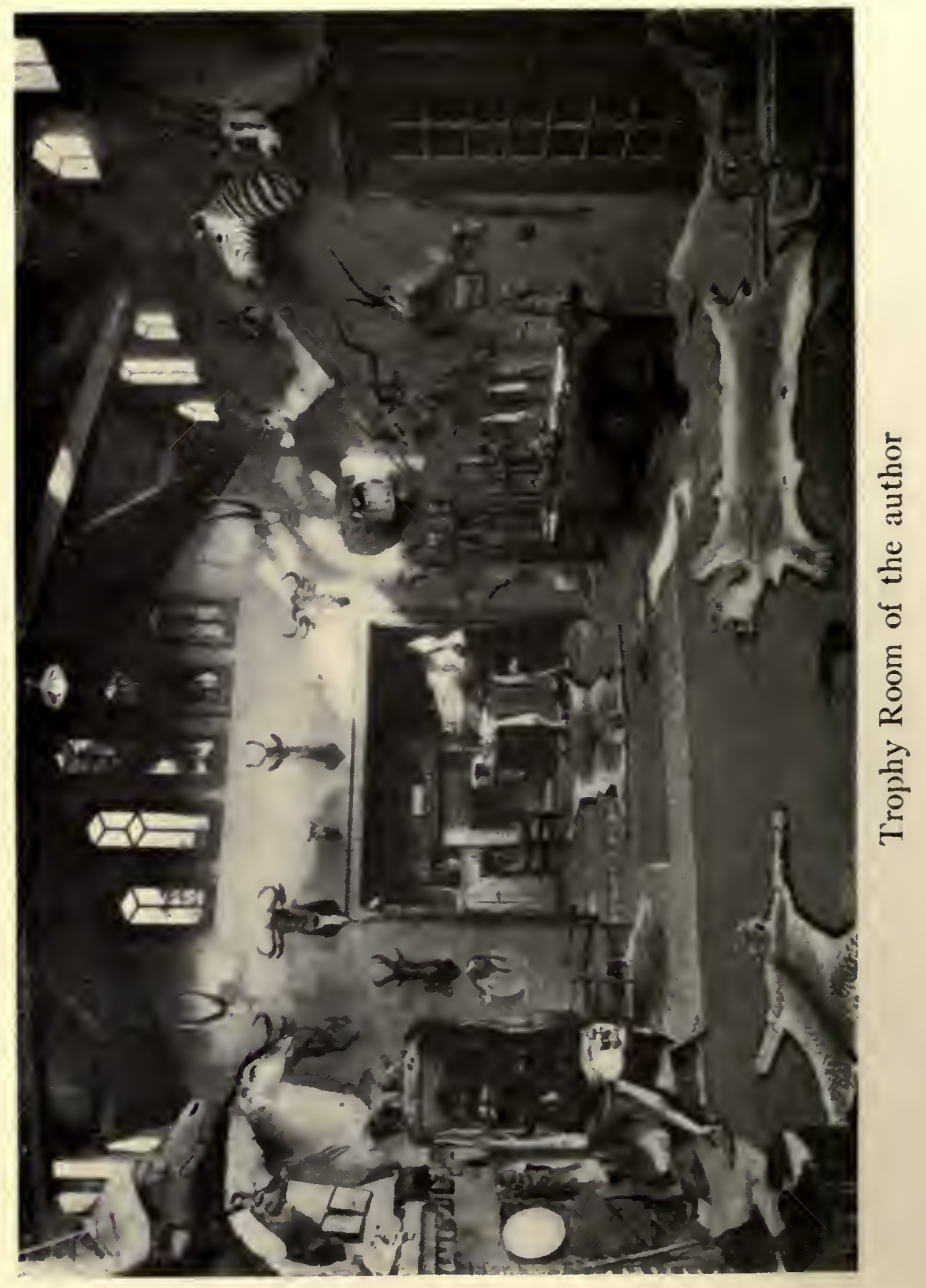




\title{
AFRICAN CAMP FIRES
}

\author{
BY \\ STEWART EDWARD WHITE, F. R. G.S.
}

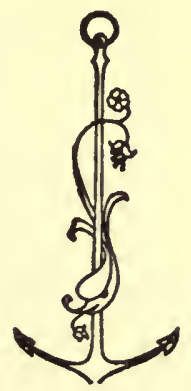

ILLUSTRATED FROM PHOTOGRAPHS

Garden City New York DOUBLEDAY, PAGE \& COMPANY 1913 


\section{Copyright, I9I3, by Doubleday, Page \& Company All rights reserved, including that of translation into foreign languages, including the Scandinavian}




\section{DT \\ 425 \\ W58a}

\section{TABLE OF CONTENTS}

Part I - To the Island of War

I. The Open Door . . . . . . 3

II. The Farewell . . . . . . .

III. Port Said . . . . . . . . 16

IV. Suez . . . . . . . . . . 25

V. The Red Sea . . . . . . . 3 I

VI. Aden . . . . . . . . . . 42

VII. The Indian Ocean . . . . . . 49

VIII. Mombasa . . . . . . . 59

Part II - The Shimba Hills

IX. A Tropical Jungle . . . . . 77

X. The Sable . . . . . . . . $\quad . \quad 89$

XI. A March Along the Coast . . . 96

XII. The Fire . . . . . . . 104

\section{PART III - NAIROBI}

XIII. Up from the Coast . . . . . II3

XIV. A Fiat Town . . . . . . . 119 


\section{TABLE OF CONTENTS}

CEAPTER

PAGE

XV. People . . . . . . . . . $\quad$ I 25

XVI. Recruiting . . . . . . . . 134

Part IV - A Lion Hunt on Kapiti

XVII. An Ostrich Farm at Machakos . I43 XVIII. The First Lioness . . . . I5I

XIX. The Dogs. . . . . . . 156

XX. Bondoni . . . . . . . . I6I

XXI. Riding the Plains . . . . . 164

XXII. The Second Lioness . . . . 176

XXIII. The Big Lion . . . . . . I8I

XXIV. The Fifteen Lions . . . . . 186

Part V-The Tsavo River

XXV. Voi

XXVI. The Fringe-Eared Oryx . . . 199 XXVII. Across the Serengetti . . . 206 XXVIII. Down the River . . . . 214

XXIX. The Lesser Kudu . . . . . 225

XXX. Adventures by the Way . . 232

XXXI. The Lost Safari . . . . 239

XXXII. The Babu . . . . . . . 247

Part VI - In Masailand

XXXIII. Over the Likipia Escarpment . 255 XXXIV. To the Kedong . . . . 267 


\section{TABLE OF CONTENTS}

CHAPTER

PAGE

XXXV. The Transport Rider. . . . 270

XXXVI. Across the Thirst . . . 278

XXXVII. The Southern Guaso Nyero • 286

XXXVIII. The Lower Benches . . . . 293

XXXIX. Notes on the Masai. . . 310

XL. Through the Enchanted Forest . 326

XLI. Naiokotoku . . . . . . 33 I

XLII. Scouting in the Elephant Forest 336

XLIII. The Topi Camp • . . . 344

XLIV. The Unknown Land . . . 352

XLV. The Roan . . . . . . 356

XLVI. The Greater Kudu . . . 366

XLVII. The Magic Portals Close • . 372

XLVIII. The Last Trek . • • • 375 



\section{ILLUSTRATIONS}

Trophy Room of the author . . Frontispiece FACING PAGE

"Camels laden with stone and in convoy of white-clad figures" . . . . . . 22

The control station . . . . . . . . 23

"Innumerable rowboats swarmed down, filled with eager salesmen of curios and ostrich plumes" . . . . . . . . . 26

Dhow in the Red Sea . . . . . . 27 Another View of the Trophy Room . . . 42 "We waited patiently to see the camels slung aboard by the crane" . . . . . . 43

Vasco da Gama Street, the principal thoroughfare of Mombaso . . . . . . 60 The trolley car of Mombaso . . . . . 60 In the ivory market of Mombasa . . . 6I The labour of Africa is carried forward by song 6I Old Portuguese fort at Mombasa . . . 68 In the Arab quarter of Mombasa. . . . 68 In the Swahili quarter of Mombasa . . . 69 The entire water supply of Mombasa is drawn from numberless picturesque wells . . 


\section{ILLUSTRATIONS}

FACING PAGE

The lazy Boabab Tree . . . . . . . 76

In the native quarter of Mombasa . . $\quad 77$

Swahili women at Mombasa . . . . 86

The slope fell gently away through a coconut

grove . . . . . . . . . . . 87

The camp beneath the mangoes . . . 87

The Sable. . . . . . . . . . . 90

"From it led a narrow path through the thicket". . . . . . . . . . 9I

"The hotel manager came forward with the offer of a gasoline launch, which we gladly accepted". . . . . . . . . . 92

"Then suddenly we found ourselves in a storybook, tropical paradise" . . . . . 93

Masai women at a station of the Uganda Railroad

Train on the Uganda Railway. "Inside a fence - before the low, stone-built, wide-verandahed hotel".

"Savages from the jungle untouched by civili-

zation - wander the streets unabashed"

Convicts marching into Nairobi in charge of

Soudanese

"But the native is the joy, and the neverceasing delight"

In the bazaar at Nairobi. Kikuyus bargaining

I 28 


\section{ILLUSTRATIONS}

"Kapiti goes on over the edge of the world to unknown, unguessed regions, rolling and troubled like a sea".

"The ostriches are kept in corrals" . . . I44

"The first lioness, the Hills and Captain Duirs"

"They closed in and began to worry the nearly

lifeless carcass" . . . . . . . . 168

Spying for lions from the kopjes . . . 169

"Kongoni" . . . . . . . . . . . 202

The Topi . . . . . . . . . . 203

The desert of the Serengetti . . . . 216

"In the river jungle" . . . . . . . 2I7

The Tsavo River below the junction. . . 217

The Lesser Kudu . . . . . . . . 228

Bushbuck - a very shy bush-dwelling animal.

This photograph is most unusual

"Each day the pinnacles over the way changed

slightly their compass directions"

$24^{8}$

Left to right - Timothy, Abba Ali, Leyeye,

Mohamet . . . . . . . . . . 249

Cuninghame . . . . . . . . . . 262

Crossing the Southern Guaso Narok . . . 263

Kingangui . . . . . . . . . . . 280

Kimau . . . . . . . . . . 280

"From it we looked down into the deep gorge of the Southern Guaso Nyero" . . . . 28I 


\section{ILLUSTRATIONS}

FACING PAGE

The Eland.

288

Cape Buffalo . . . . . . . . . . 288

The Fourth Bench . . . . . . . 289

The Valley of Lengeetoto . . . . . 304

Cheetah . . . . . . . . . 304

Our camp at the Naróssara . . . . 305

Our camp in Lengeetoto . . . . . 305

Illustrating the heavy iron jewellery. . . 3ro

Unmarried woman with goatskin robe . . 310

"These low-rounded huts in shape like a loaf of bread". . . . . . . . . 3II

"Upward of a thousand head in charge of two old women on foot" . . . . . 314 "They visited camp freely, and would sit down for a good lively afternoon of joking" 315 Warriors

"The southern branch of the race - are very fine physically". . . . . . 324

Masai men and women . . . . . 325

"In the southern districts the warriors wear two single black ostrich feathers"

325

"The girl in the middle ground has painted her face white to indicate travel"

332

When moving the villages they take with them only the wicker doors . . . . . . 332

Masai with headdress of lion's mane . . 333 


\section{ILLUSTRATIONS}

A neophyte with headdress of small bird skins 333 The El-morani is an imposing figure . . 340 Masai El-morani, or warrior . . . . 340 Construction of V.'s boma . . . . . . 34I "I offered a half rupee as a prize for an archery competition" . . . . . . . . 348

Naiokotuku and one of his sons . . . . 349 Our southernmost camp. From this point we turned back . . . . . . . . . 352 "We called the Masai and Wanderobo before us".

A present from Naiokotuku . . . . . 353 The Roan . . . . . . . . . . 360 "It was almost exactly like the sage-brush deserts". . . . . . . . 36I "In the Elephant country" . . . . . 368 The Greater Kudu . . . . . . . . 369 

AFRICAN CAMP FIRES 



\section{AFRICAN CAMP FIRES}

\section{I \\ THE OPEN DOOR}

THERE are many interesting hotels scattered

1 about the world, with a few of which I am acquainted and with a great many of which I am not. Of course all hotels are interesting, from one point of view or another. In fact the surest way to fix an audience's attention is to introduce your hero, or to display your opening chorus in the lobby or along the façade of a hotel. The life, the movement and colour, the shifting individualities, the pretence, the bluff, the self-consciousness, the independence, the ennui, the darting or lounging servants, the very fact that of those before your eyes seven out of ten are drawn from distant and scattered places, are sufficient in themselves to invest the smallest hostelry with glamour. It is not of this general interest that I would now speak. Nor is it my intention at present to glance at the hotels wherein 


\section{AFRICAN CAMP FIRES}

"quaintness" is specialized, whether intentionally or no. There are thousands of them; and all of them well worth the discriminating traveller's attention. Concerning some of them - as the old inns at Dives-sur-mer and at Mont St. Michel whole books have been written. These depend for their charm on a mingled gift of the unusual and the picturesque. There are, as I have said, thousands of them; and of their cataloguing, should one embark on so wide a sea, there could be no end. And, again, I must for convenience exclude the altogether charming places like the Tour d'Argent of Paris, Simpsons of the Strand, ${ }^{*}$ and a dozen others that will spring to every traveller's memory, where the personality of the host, or of a chef, or even a waiter, is at once a magnet for the attraction of visitors and a reward for their coming. These too are many. In the interest to which I would draw attention, the hotel as a building or as an institution has little part. It is indeed a façade, a mise en scene before which play the actors that attract our attention and applause. The set may be as modernly elaborate as Peacock Alley of the Waldorf or the templed lobby of the St. Francis; or it may present the severe and Elizabethan simplicity of the stone-paved veranda of the Norfolk at Nairobi - the matter is

\footnotetext{
"In old days before the "improvements." •
} 


\section{THE OPEN DOOR}

quite inessential to the spectator. His appreciation is only slightly and indirectly influenced by these things. Sunk in his arm-chair - of velvet or of canvas - he puffs hard and silently at his cigar, watching and listening as the pageant and the conversation eddy by.

Of such hotels I number that gaudy and polysyllabic hostelry the Grand Hotel du Louvre et de la Paix at Marseilles. I am indifferent to the facts that it is situated on that fine thoroughfare, the Rue de Cannebiere, which the proud and untravelled native devoutly believes to be the finest street in the world; that it possesses a dining-room of gilded and painted repousse work so elaborate and wonderful that it surely must be intended to represent a tinsmith's dream of heaven; that its concierge is the most impressive human being on earth except Ludwig Von Kampf, whom I have never seen; that its head waiter is sadder and more elderly and forgiving than any other head waiter; and that its hushed and cathedral atmosphere has been undisturbed through immemorial years. That is to be expected; and elsewhere to be duplicated in greater or lesser degree. Nor in the lofty courtyard, or the equally lofty halls and reading rooms, is there ever much bustle and movement. People sit quietly, or move with circumspection. Servants 


\section{AFRICAN CAMP FIRES}

glide. The fall of a book or teaspoon, the sudden closing of a door, are events to be remarked. Once a day, however, a huge gong sounds, the glass doors of the inner courtyard are thrown open with a flourish, and enter the huge 'bus fairly among those peacefully sitting at the tables, horses' hoofs striking fire, long lash cracking volleys, wheels roaring amid hollow reverberations. From the interior of this 'bus emerge people; and from the top, by means of a strangely constructed hooked ladder, are descended boxes and trunks and appurtenances of various sorts. In these people and in these boxes, trunks, and appurtenances are the real interest of the Grand Hotel du Louvre et de la Paix of the marvellous Rue Cannebiere of Marseilles.

For at Marseilles land ships, many ships, from all the scattered ends of the earth; and from Marseilles depart trains for the North, where is home, or the way home, for many peoples. And since the arrival of ships is uncertain, and the departure of trains fixed, it follows that everybody descends for a little or greater period at the Grand Hotel du Louvre et de la Paix.

They come lean and quiet and a little yellow from hard climates, with the names of strange places on their lips, and they speak familiarly of far-off things. Their clothes are generally of ancient cut, and the 


\section{THE OPEN DOOR}

wrinkles and camphor aroma of a long packing away are yet discernible. Often they are still wearing sun helmets or double terai hats pending a descent on a Piccadilly hatter two days hence. They move slowly and languidly; the ordinary piercing and dominant English enunciation has fallen to modulation; their eyes, while observant and alert, look tired. It is as though the far countries have sucked something from the pith of them in exchange for great experiences that nevertheless seem of little value; as though these men, having met at last face to face the ultimate of what the earth has to offer in the way of danger, hardship, difficulty and the things that try men's souls, having unexpectedly found them all to fall short of both the importance and the final significance with which human-kind has always invested them, were now just a little at a loss. Therefore they stretch their long, lean frames in the wicker chairs, they sip the long drinks at their elbows, puff slowly at their long, lean cheroots, and talk spasmodically in short sentences.

Of quite a different type are those going out young fellows full of northern health and energy, full of the eagerness of anticipation, full of romance skilfully concealed, self-certain, authoritative, clear voiced. Their exit from the 'bus is followed by a rain of hold-alls, bags, new tin boxes, new gun cases, 


\section{AFRICAN CAMP FIRES}

all lettered freshly - an enormous kit doomed to diminution. They overflow the place, ebb toward their respective rooms; return scrubbed and ruddy, correctly clad, correctly unconscious of everybody else; sink into more wicker chairs. The quiet brown and yellow men continue to puff on their cheroots, quite eclipsed. After a time one of them picks up his battered old sun helmet and goes out into the street. The eyes of the newcomers follow him. They fall silent; and their eyes, under cover of pulled moustache, furtively glance toward the lean man's companions. Then on that office falls a great silence, broken only by the occasional rare remarks of the quiet men with the cheroots. The youngsters are listening with all their ears, though from their appearance no one would suspect that fact. Not a syllable escapes them. These quiet men have been there, they have seen with their own eyes, their lightest word is saturated with the mystery and romance of the unknown. Their easy, matter-of-fact, everyday knowledge is richly wonderful. It would seem natural for these youngyoung men to question these old-young men of that which they desire so ardently to know; but that isn't done, you know. So they sit tight, and pretend they are not listening, and feast their ears on the wonderful syllables-Ankobur, Kabul, 


\section{THE OPEN DOOR}

Peshawur, Annam, Nyassaland, Kerman, Serengetti, Tanganyika and many others. On these beautiful syllables must their imaginations feed, for that which is told is as nothing at all. Adventure there is none, romance there is none, mention of high emprise there is none. Adventure, romance, high emprise have to these men somehow lost their importance. Perhaps such things have been to them too common - as well mention the morning egg. Perhaps they have found that there is no genuine adventure, no real romance except over the edge of the world where the rainbow stoops.

The 'bus rattles in and rattles out again. It takes the fresh-faced young men down past the inner harbour to where lie the tall ships waiting. They and their cargo of exuberance, of hope, of energy, of thirst for the bubble adventure, the rainbow romance, sail away to where these wares have a market. And the quiet men glide away to the north. Their wares have been marketed. The sleepy, fierce, passionate, sunny lands have taken all they had to bring. And have given in exchange? Indifference, ill-health, a profound realization that the length of days are as nothing at all, a supreme agnosticism as to the ultimate value of anything that a single man can do, a sublime faith that it must be done, the power to concentrate, patience 


\section{AFRICAN CAMP FIRES}

illimitable, contempt for danger, disregard of death, the intention to live, a final, weary estimate of the fact that mere things are as unimportant here as there, no matter how quaintly or fantastically they are dressed or named, and a corresponding emptiness of anticipation for the future - these items are only a random few of the price given by the ancient lands for that which the northern races bring to them. What other alchemical changes have been wrought only these lean and weary men could know - if they dared look so far within themselves. And even if they dared, they would not tell. 


\section{II}

\section{THE FAREWELL}

\section{WE BOARDED ship filled witn a great, and}

what seemed to us an unappeasable, curiosity as to what we were going to see. It was not a very big ship, in spite of the grandiloquent descriptions in the advertisements, or the lithograph wherein she cut grandly and evenly through huge waves to the manifest discomfiture of infinitesimal sailing craft bobbing alongside. She was manned entirely by Germans. The room stewards waited at table, cleaned the public saloons, kept the library, rustled the baggage, and played in the band. That is why we took our music between meals. Our staterooms were very tiny indeed. Each was provided with an electric fan; a totally inadequate and rather aggravating electric fan once we had entered the Red Sea. Just at this moment we paid it little attention, for we were still in full enjoyment of sunny France where, in our own experience, it had rained two months steadily. Indeed, at this moment it was raining; raining a steady, cold, sodden drizzle that had not 


\section{AFRICAN CAMP FIRES}

even the grace to pick out the surface of the harbour in the jolly dancing staccato that goes far to lend attraction to a genuinely earnest rainstorm.

Down the long quai splashed cabs and omnibuses, their drivers glistening in wet capes, to discharge under the open shed at the end various hasty individuals who marshalled long lines of porters with astonishing impedimenta and drove them up the gangplank. A half-dozen roughs lounged aimlessly. A little bent old woman with a shawl over her head searched here and there. Occasionally she would find a twisted splinter of wood torn from the piles by a hawser, or gouged from the planking by heavy freight, or kicked from the floor by the hoofs of horses. This she deposited carefully in a small covered market basket. She was entirely intent on this minute and rather pathetic task, quite unattending the greatness of the ship, or the many people the great hulk swallowed or spat forth.

Near us against the rail leaned a dark-haired young Englishman whom later every man on that many-nationed ship came to recognize and to avoid as an insufferable bore. Now, however, the angel of good inspiration stooped to him. He tossed a copper two-sou piece down to the bent old woman. She heard the clink of the fall, and looked up bewildered. One of the waterside roughs slouched for- 


\section{THE FAREWELL}

ward. The Englishman shouted a warning and a threat, indicating in pantomime for whom the coin was intended. To our surprise that evil-looking wharf rat smiled and waved his hand reassuringly; then took the old woman by the arm to show her where the coin had fallen. She hobbled to it with a haste eloquent of the horrible Marseillaise povertystricken alleys, picked it up joyously, turned and with a delightful grace kissed her finger-tips toward the ship.

Apparently we all of us had a few remaining French coins; and certainly we were all grateful to the young Englishman for his happy thought. The sous descended as fast as the woman could get to where they fell. So numerous were they that she had no time to express her gratitude except in broken snatches of gesture, in interrupted attitudes of the most complete thanksgiving. The day of miracles for her had come; and from the humble poverty that valued tiny and infrequent splinters of wood she had suddenly come into great wealth. Everybody was laughing, but in a very kindly sort of way, it seemed to me; and the very wharf rats and gamins, wolfish and fierce in their everyday life of the waterfront, seemed to take a genuine pleasure in pointing out to her the resting place of those her dim old eyes had not seen. Silver pieces followed. 


\section{AFRICAN CAMP FIRES}

These were too wonderful. She grew more and more excited, until several of the passengers leaning over the rail began to murmur warningly, fearing harm. After picking up each of these silver pieces, she bowed and gestured very gracefully, waving both hands outward, lifting eyes and hands to heaven, kissing her fingers, trying by every means in her power to express the dazzling wonder and joy that this unexpected marvel was bringing her. When she had done all these things many times, she hugged herself ecstatically. A very well-dressed and prosperous-looking Frenchman standing near seemed to be a little afraid she might hug him. His fear had, perhaps, some grounds, for she shook hands with everybody all around, and showed them her wealth in her kerchief, explaining eagerly, the tears running down her face.

Now the gangplank was drawn aboard, and the band struck up the usual lively air. At the first notes the old woman executed a few feeble little jig steps in sheer exuberance. Then the solemnity of the situation sobered her. Her great, wealthy, powerful, kind friends were departing on their long voyage over mysterious seas. Again and again, very earnestly, she repeated the graceful, slow pantomime - the wave of the arms outward, the eyes raised to heaven, the hands clasped finally over her 


\section{THE FAREWELL}

head. As the brown strip of water silently widened between us it was strangely like a stage scene - the roofed sheds of the quai, the motionless groups, the central figure of the old woman depicting emotion.

Suddenly she dropped her hands and hobbled away at a great rate, disappearing finally into the maze of the street beyond. Concluding that she had decided to get quickly home with her great treasure, we commended her discretion and gave our attention to other things.

The drizzle fell uninterruptedly. We had edged sidewise the requisite distance, and were now gathering headway in our long voyage. The quai was beginning to recede and to diminish. Back from the street hastened the figure of the little old woman. She carried a large white cloth, of which she had evidently been in quest. This she unfolded and waved vigorously with both hands. Until we had passed quite from sight she stood there signalling her farewell. Long after we were beyond distinguishing her figure we could catch the flutter of white. Thus that ship's company, embarking each on his Great Adventure, far from home and friends, received his farewell, a very genuine farewell, from one poor old woman. B. ventured the opinion that it was the best thing we had bought with our French money. 


\section{III}

\section{PORT SAID}

7 time of times to approach Port Said is just 1 at the fall of dusk. Then the sea lies in opalescent patches, and the low shores fade away into the gathering night. Slanting masts and yards of the dhows silhouette against a sky of the deepest translucent green; and the heroic statue of De Lesseps standing forever at the Gateway he opened, points always to the mysterious East.

The rhythmical, accustomed chug of the engines had fallen to quarter speed, leaving an uncanny stillness throughout the ship. Silently we slipped between the long piers, drew up on the waterside town, seized the buoy, and came to rest. All around us lay other ships of all sizes, motionless on the inky water. The reflections from their lights seemed to be thrust into the depths, like stilts; and the few lights from the town reflected shiveringly across. Along the waterfront all was dark and silent. We caught the loom of buildings; and behind them a dull glow as from a fire, and guessed tall minar- 


\section{PORT SAID}

ets, and heard the rising and falling of chanting. Numerous small boats hovered near, floating in and out of the patches of light we ourselves cast, waiting for permission to swarm at the gangplank for our patronage.

We went ashore, passed through a wicket gate, and across the dark buildings to the heart of the town, whence came the dull glow and the sounds of people.

Here were two streets running across one another, both brilliantly lighted, both thronged, both lined with little shops. In the latter one could buy anything, in any language, with any money. We saw cheap straw hats made in Germany hung side by side with gorgeous and beautiful stuffs from the orient; shoddy European garments and Eastern jewels; cheap celluloid combs and curious embroideries. The crowd of passersby in the streets were compounded in the same curiously mixed fashion; a few Europeans, generally in white, and then a variety of Arabs, Egyptians, Somalis, Berbers, East Indians and the like, each in his own gaudy or graceful costume. It speaks well for the accuracy of feeling, anyway, of our various "Midways," "Pikes," and the like of our world's expositions that the streets of Port Said looked like Midways raised to the ${ }^{n}$ th power. Along them we sauntered with a pleasing feeling of self-importance. On all sides 


\section{AFRICAN CAMP FIRES}

we were gently and humbly besought - by the shopkeepers, by the sidewalk vendors, by would-be guides, by fortune tellers, by jugglers, by magicians; all soft-voiced and respectful; all yielding as water to rebuff, but as quick as water to glide back again. The vendors were of the colours of the rainbow, and were heavily hung with long necklaces of coral or amber, with scarves, with strings of silver coins, with sequinned veils and silks, girt with many dirks and knives, furnished out in concealed pockets with scarabs, bracelets, sandal-wood boxes or anything else under the broad canopy of heaven one might or might not desire. Their voices were soft and pleasing, their eyes had the beseeching quality of a good dog's, their anxious and deprecating faces were ready at the slightest encouragement to break out into the friendliest and most intimate of smiles. Wherever we went we were accompanied by a retinue straight out of the Arabian Nights, patiently awaiting the moment when we should tire; should seek out the table of a sidewalk café; and should, in our relaxed mood, be ready to unbend to our royal purchases.

At that moment we were too much interested in the town itself. $\mathrm{T}$ e tiny shops with their smiling and insinuating oriental keepers were fascinating in their displays of carved woods, jewellery, 


\section{PORT SAID}

perfumes, silks, tapestries, silversmith's work, ostrich feathers and the like. Either side the main street lay long, narrow, dark alleys in which flared single lights, across which flitted mysterious, long, robed figures, from which floated stray snatches of music either palpitatingly barbaric or ridiculously modern. There the authority of the straight soldierly looking Soudanese policemen ceased; and it was not safe to wander unarmed or alone.

Besides these motley variegations of the East and West, the main feature of the town was the street car. It was an open-air structure of spacious dimensions, as though benches and a canopy had been erected rather haphazard on a small dancing platform. The track is absurdly narrow in gauge; and as a consequence the edifice swayed and swung from side to side. A single mule was attached to it loosely by about ten feet of rope. It was driven by a gaudy ragamuffin in a turban. Various other gaudy ragamuffins lounged largely and picturesquely on the widely spaced benches. Whence it came or whither it went I do not know. Its orbit swung into the main street, turned a corner and disappeared. Apparently Europeans did not patronize this picturesque wreck, but drove elegantly but mysteriously in small open cabs conducted by totally incongruous turbaned drivers. 


\section{AFRICAN CAMP FIRES}

We ended finally at an imposing corner hotel where we dined by an open window just above the level of the street. A dozen upturned faces besought us silently during the meal. At a glance of even the mildest interest a dozen long, brown arms thrust the spoils of the East upon our consideration. With us sat a large benign Swedish professor whose erudition was encyclopædic, but whose kindly humanity was greater. Uttering deep, cavernous chuckles the Professor bargained. A red coral necklace for the moment was the matter of interest. The Professor inspected it carefully, and handed it back.

"I doubt if id iss coral," said he simply.

The present owner of the beads went frantic with rapid-fire proof and vociferation. With the swiftness and precision of much repetition he fished out a match, struck it, applied the flame to the alleged coral, and blew out the match; cast the necklace on the pavement, produced mysteriously a small hammer, and with it proceeded madly to pound the beads. Evidently he was accustomed to being doubted, and carried his materials for proof around with him. Then, in one motion, the hammer disappeared; the beads were snatched up, and again offered, unharmed, for inspection.

"Are those good tests for genuineness?" we asked the Professor, aside. 


\section{PORT SAID}

"As to that," he replied regretfully, "I do not know. I know of coral only that is the hard calcareous skeleton of the marine cœlenterate polyps; and that this red coral iss called of a sclerobasic group; and other facts of the kind; but I do not know if it iss supposed to resist impact and heat. Possibly," he ended shrewdly, "it is the common imitation which does not resist impact and heat. At any rate they are pretty. How much?" he demanded of the vendor, a bright-eyed Egyptian waiting patiently until our conference should cease.

"Twenty shillings," he replied promptly.

The Professor shook with one of his cavernous chuckles.

"Too much," he observed, and handed the necklace back through the window.

The Egyptian would by no means receive it.

"Keep! keep!" he implored, thrusting the mass of red upon the Professor with both hands. "How much you give?"

"One shilling," announced the Professor firmly.

The coral necklace lay on the edge of the table throughout most of our leisurely meal. The vendor argued, pleaded, gave it up, disappeared in the crowd, returned dramatically after an interval. The Professor ate calmly, chuckled much, and from time to time repeated firmly the words, "One 


\section{AFRICAN CAMP FIRES}

shilling." Finally, at the cheese, he reached out, swept the coral into his pocket, and laid down two shillings. The Egyptian deftly gathered the coin, smiled cheerfully, and produced a glittering veil in which he tried in vain to enlist Billy's interest.

For coffee and cigars we moved to the terrace outside. Here an orchestra played, the peoples of many nations sat at little tables, the peddlers, fakirs, jugglers, and fortune tellers swarmed. A half dozen postal cards seemed sufficient to set a small boy up in trade, and to imbue him with all the importance and insistence of a merchant with jewels. Other ten-year-old ragamuffins tried to call our attention to some sort of sleight-of-hand with poor downy little chickens. Grave turbaned and polite Indians squatted crosslegged at our feet begging to give us a look into the future by means of the only genuine hallmarked Yogism; a troupe of acrobats went energetically and hopefully through quite a meritorious performance a few feet away; a deftly triumphant juggler did very easily, and directly beneath our watchful eyes, some really wonderful tricks. A butterfly-gorgeous swarm of insinuating smiling peddlers of small things dangled and spread their wares where they thought themselves most sure of attention. Beyond our own little group we saw slowly passing in the lighted street outside the 


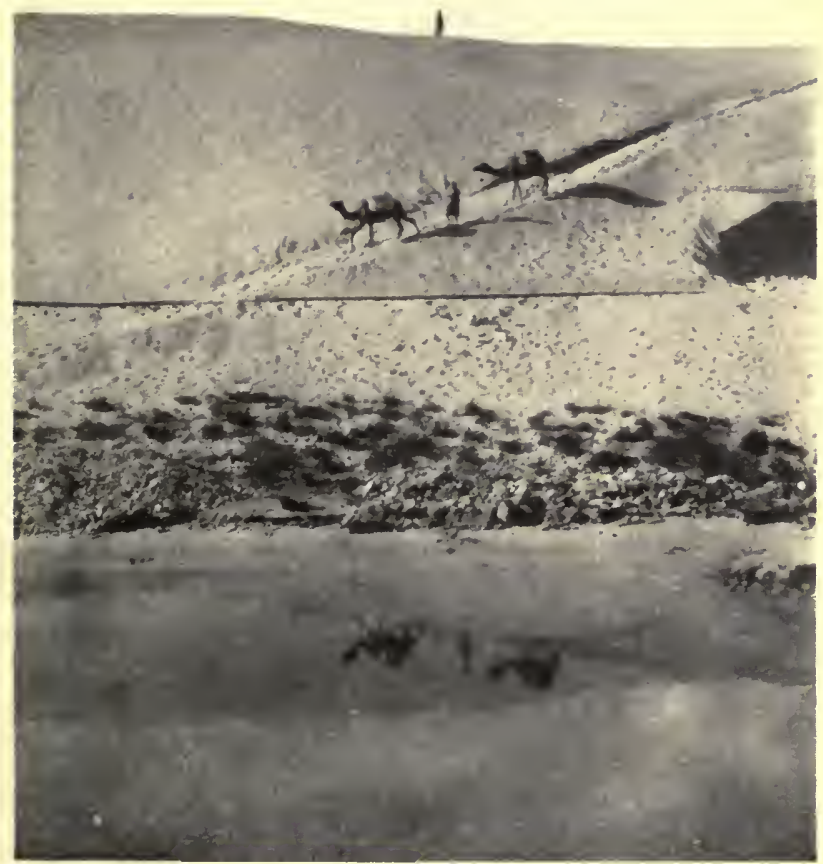

"Camels laden with stone and in convoy of white-clad figures shuffled down the slope at a picturesque angle" 


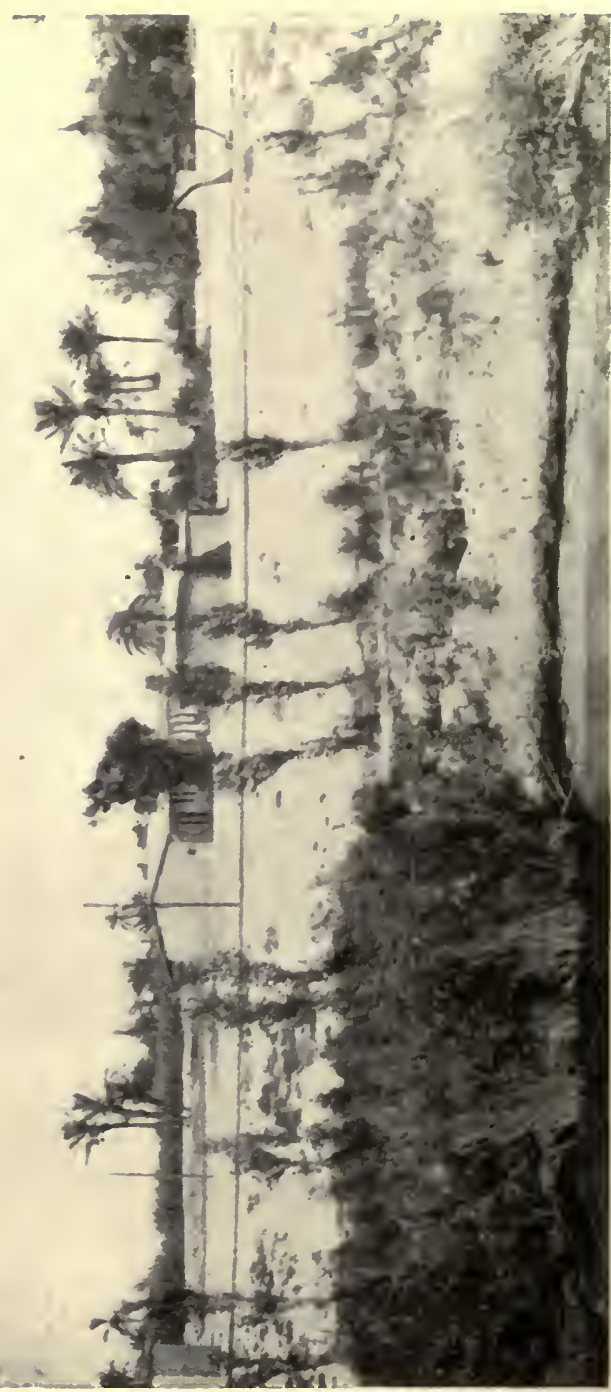

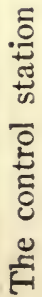




\section{PORT SAID}

portico the variegated and picturesque loungers. Across the way a phonograph bawled; our stringed orchestra played "The Dollar Princess"; from somewhere over in the dark and mysterious alleyways came the regular beating of a tom-tom. The magnificent and picturesque town car with its gaudy ragamuffins swayed by in train of its diminutive mule.

Suddenly our persistent and amusing entourage vanished in all directions. Standing idly at the portico was a very straight, black Soudanese. On his head was the usual red fez; his clothing was of trim khaki; his knees and feet were bare, with blue puttees between; and around his middle was drawn close and smooth a blood-red sash at least a foot and a half in breadth. He made a fine upstanding Egyptian figure, and was armed with pride, a short sheathed club, and a great scorn. No word spoke he, nor command; but merely jerked a thumb toward the darkness, and into the darkness our many-hued horde melted away. We were left feeling rather lonesome!

Near midnight we sauntered down the street to the quai, whence we were rowed to the ship by another turbaned, long-robed figure who sweetly begged just a copper or so "for poor boatman."

We found the ship in the process of coaling, every porthole and doorway closed, and heavy canvas hung to protect as far as possible the clean decks. 


\section{AFRICAN CAMP FIRES}

Two barges were moored alongside. Two blazing braziers lighted them with weird red and flickering flames. In their depths, cast in black and red shadows, toiled half-guessed figures; from their depths, mounting a single steep plank, came an unbroken procession of natives, naked save for a wisp of cloth around the loins. They trod closely on each other's heels, carrying each his basket atop his head or on one shoulder, mounted a gangplank, discharged their loads into the side of the ship, and descended again to the depths by way of another plank. The lights flickered across their dark faces, their gleaming teeth and eyes. Somehow the work demanded a heap of screeching, shouting, and gesticulation; but somehow also it went forward rapidly. Dozens of unattached natives lounged about the gunwales with apparently nothing to do but to look picturesque. Shore boats moved into the narrow circle of light, drifted to our gangway and discharged huge crates of vegetables, sacks of unknown stuffs, and returning passengers. A vigilant police boat hovered near to settle disputes, generally with the blade of an oar. For a long time we leaned over the rail watching them, and the various reflected lights in the water, and the very clear, unwavering stars. Then, the coaling finished, and the portholes once more opened, we turned in. 


\section{IV}

\section{SUEZ}

GOMETIME during the night we must have S started, but so gently had we slid along at fractional speed that until I raised my head and looked out I had not realized the fact. I saw a high sand bank. This glided monotonously by until I grew tired of looking at it; and got up.

After breakfast, however, I found that the sand bank had various attractions all of its own. Three camels laden with stone and in convoy of white-clad figures shuffled down the slope at a picturesque angle. Two cowled women in black, veiled to the eyes in gauze heavily sewn with sequins, barefooted, with massive silver anklets, watched us pass. Hindoo workmen in turban and loin cloth furnished a picturesque note, but did not seem to be injuring themselves by overexertion. Naked small boys raced us for a short distance. The banks glided by very slowly and very evenly, the wash sucked after us like water in a slough after a duck boat, and the sky above the yellow sand looked extremely blue. 


\section{AFRICAN CAMP FIRES}

At short and regular intervals, halfway up the minature sandhills, heavy piles or snubbing posts had been planted. For these we at first could guess no reason. Soon, however, we had to pass another ship; and then we saw that one of us must tie up to avoid being drawn irresistibly by suction into collision with the other. The craft sidled by, separated by only a few feet; so that we could look across to each other's decks, and exchange greeting. As the day grew this interest grew likewise. Dredgers in the canal; rusty tramps flying unfamiliar flags of strange tiny countries; big freighters, often with Greek or Turkish characters on their sterns; small, dirty steamers of suspicious business; passenger ships like our own, returning from the tropics, with white-clad, languid figures reclining in canvas chairs; gunboats of this or that nation bound on mysterious affairs; once a P. \&. O. converted into a troopship from whose every available porthole, hatch, deck, and shroud laughing, brown, English faces shouted chaff at our German decks - all these either tied up for us, or were tied up for by us. The only craft that received no consideration on our part were the various picturesque Arab dhows, with their single masts and the long yards slanting across them. Since these were very small, our suction dragged at them cruelly. As a usual thing four vociferous 


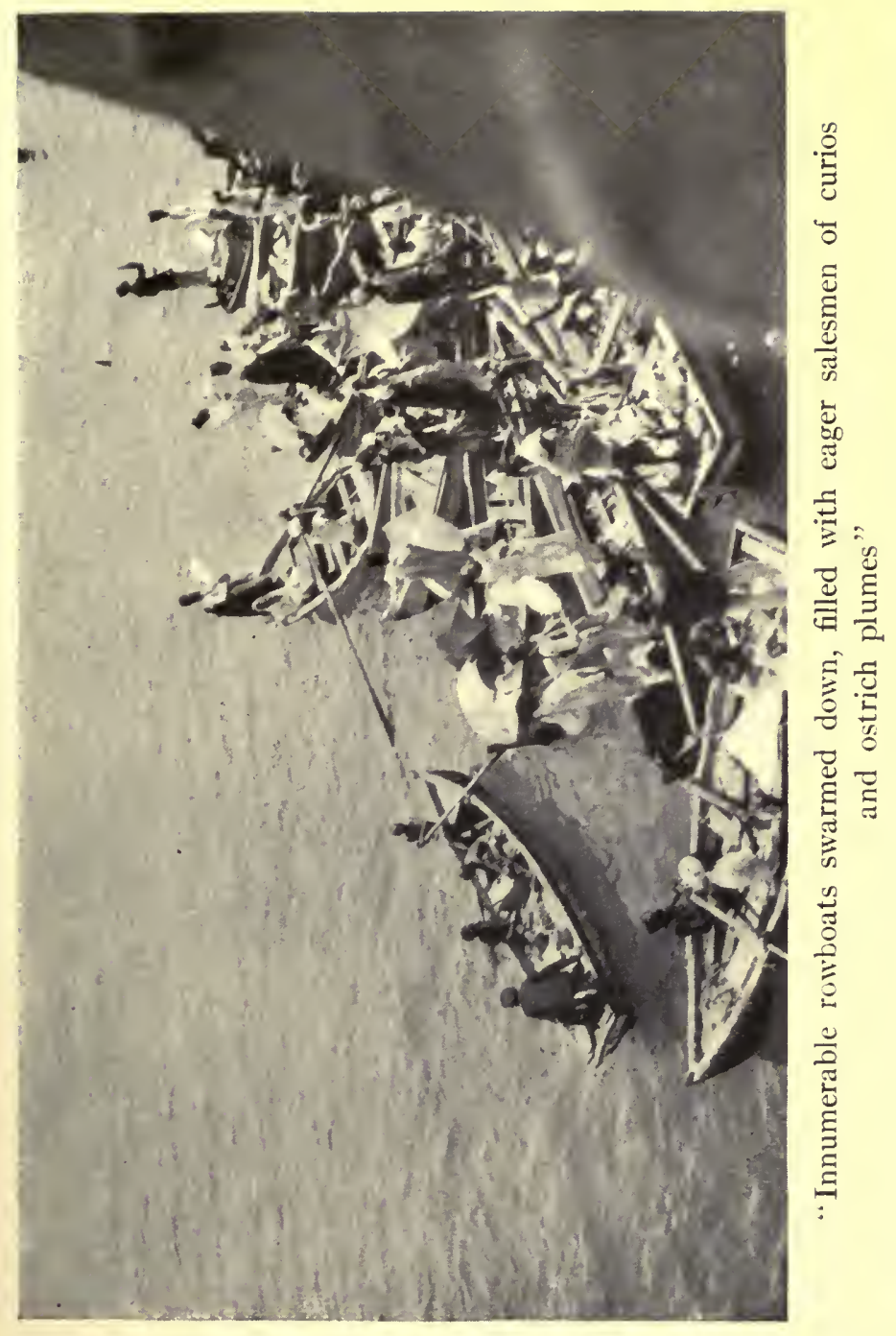




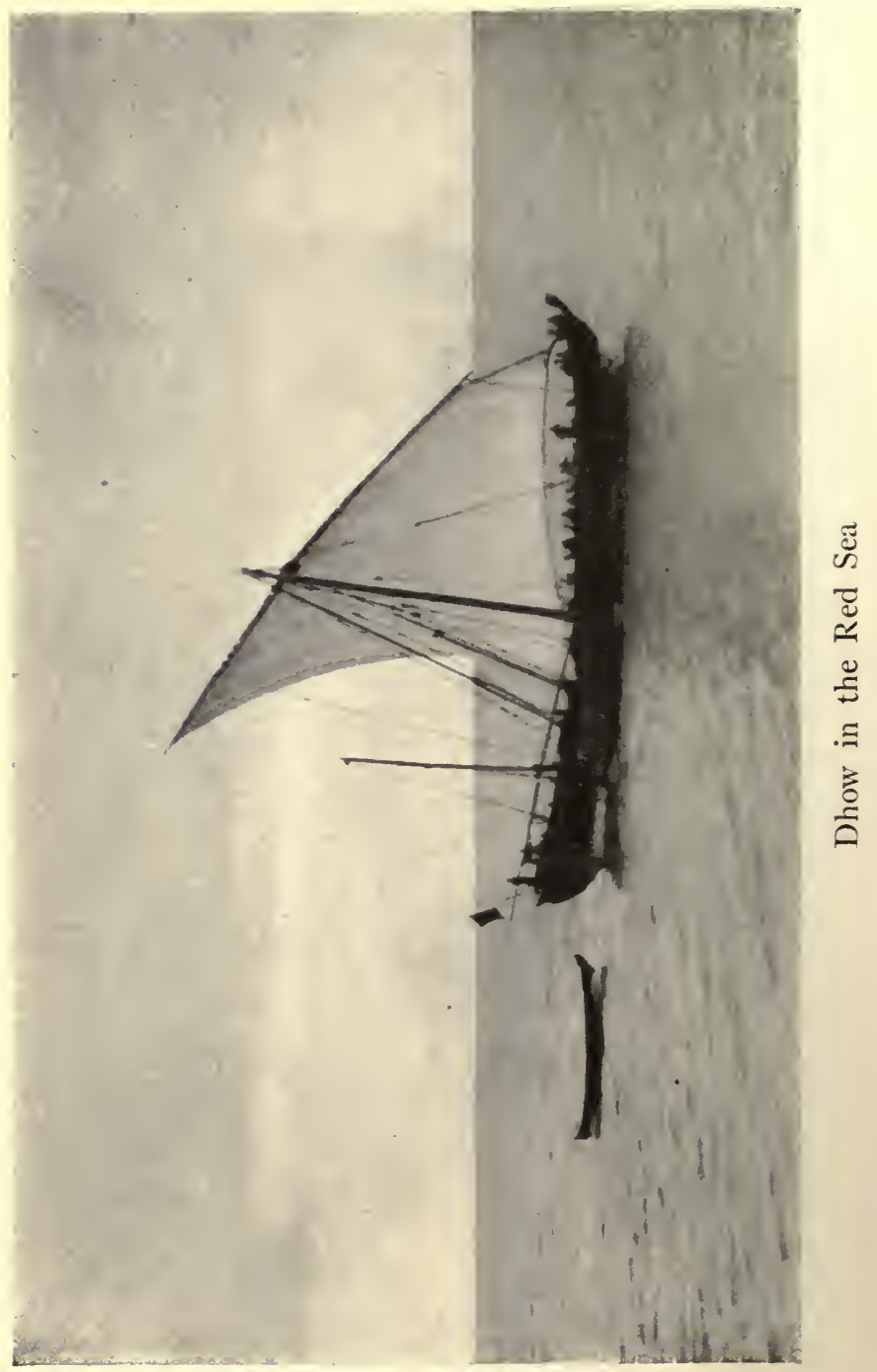




\section{SUEZ}

figures clung desperately to a rope passed around one of the snubbing posts ashore, while an old man shrieked syllables at them from the dhow itself. As they never by any chance thought of mooring her both stem and stern, the dhow generally changed ends rapidly, shipping considerable water in the process. It must be very trying to get so excited in a hot climate.

The high sand banks of the early part of the day soon dropped lower to afford us a wider view. In its broad, general features the country was, quite simply, the best desert of Arizona over again. There were the same high, distant and brittle-looking mountains, fragile and pearly; the same low, broken halfdistances; the same wide sweeps; the same wonderful changing effects of light, colour, shadow, and mirage; the same occasional strips of green marking the water courses and oases. As to smaller detail we saw many interesting divergences. In the foreground constantly recurred the Bedouin brush shelters, each with its picturesque figure or so of flowing robes, and its grumpy camels. Twice we saw travelling caravans, exactly like the Bible pictures. At one place a single burnoused Arab, leaning on his elbows, reclined full length on the skyline of a clean-cut sand hill. Glittering in the mirage, half-guessed, half-seen, we made out distant little 


\section{AFRICAN CAMP FIRES}

white towns with slender palm trees. At places the water from the canal had overflowed wide tracts of country. Here along the shore we saw thousands of the water-fowl already familiar to us, as well as such strangers as gaudy kingfishers, ibises, and rosy flamingoes.

The canal itself seemed to be in a continual state of repair. Dredgers were everywhere; some of the ordinary shovel type, others working by suction, and discharging far inland by means of weird huge pipes that apparently meandered at will over the face of nature. The control stations were beautifully French and neat, painted yellow, each with its gorgeous bougainvilleas in flower, its square-rigged signal masts, its brightly painted extra buoys standing in a row, its wharf - and its impassive Arab fishermen thereon. We reclined in our canvas chairs, had lime squashes brought to us, and watched the entertainment steadily and slowly unrolled before us.

We reached the end of the canal about three o'clock of the afternoon, and dropped anchor far off low-lying shores. Our binoculars showed us white houses in apparently single rank along a far-reaching narrow sand spit, with sparse trees and a railroad line. That was the town of Suez, and seemed so little interesting that we were not particularly sorry that we could not go ashore. Far in the distance 


\section{SUEZ}

were mountains; and the water all about us was the light, clear green of the sky at sunset.

Innumerable dhows and rowboats swarmed down, filled with eager salesmen of curios and ostrich plumes. They had not much time in which to bargain, so they made it up in rapid-fire vociferation. One very tall and dignified Arab had as sailor of his craft the most extraordinary creature, just above the lower limit of the human race. He was of a dull coal black, without a single high light on him anywhere, as though he had been sanded; had prominent teeth, like those of a baboon, in a wrinkled, wizened monkey face across which were three tattooed bands; and possessed a little long-armed spare figure, bent and wiry. He clambered up and down his mast, fetching things at his master's behest; leaped nonchalantly for our rail or his own spar, as the case might be, across the staggering abyss; clung so well with his toes that he might almost have been classified with the quadrumana; and between times squatted humped over on the rail watching us with bright, elfish, alien eyes.

At last the big German sailors bundled the whole variegated horde overside. It was time to go; and our anchor chain was already rumbling in the hawse pipes. They tumbled hastily into their boats; and at once swarmed up their masts, whence they fever- 


\section{AFRICAN CAMP FIRES}

ishly continued their interrupted bargaining. In fact so fully embarked on the tides of commerce were they that they failed to notice the tides of nature widening between us. One old man, in especial, at the very top of his mast, jerked hither and thither by the sea, continued imploringly to offer an utterly ridiculous carved wooden camel long after it was possible to have completed the transaction should anybody have been moonstruck enough to have desired it. Our ship's prow swung; and just at sunset, as the lights of Suez were twinkling out one by one, we headed down the Red Sea. 


\section{V \\ THE RED SEA}

GUEZ is indeed the gateway to the East. In the $\mathcal{N}$ Mediterranean often the sea is rough, the winds cold, passengers are not yet acquainted and hug the saloons or the leeward side of the deck. Once through the canal and all is changed by magic. The air is hot and languid; the ship's company down to the very scullions appear in immaculate white; the saloon chairs and transoms even are put in white coverings; electric fans hum everywhere; the run on lime squashes begins; and many quaint and curious customs of the tropics obtain.

For example; it is etiquette that before eight o'clock one may wander the decks at will in one's pajamas, converse affably with fair ladies in pigtail and kimono, and be not abashed. But on the stroke of eight bells it is also etiquette to disappear very promptly and to array one's self for the day; and it is very improper indeed to see or be seen after that hour in the rather extreme negligée of the early morning. Also it becomes the universal custom, or 


\section{AFRICAN CAMP FIRES}

perhaps I should say the necessity, to slumber for an hour after the noon meal. Certainly sleep descending on the tropical traveller is armed with a bludgeon. Passengers, crew, steerage, "deck," animal, and bird fall down then in an enchantment. I have often wondered who navigates the ship during that sacred hour; or, indeed, if anybody navigates it at all. Perhaps that time is sacred to the genii of the old East, who close all prying mortal eyes, but in return lend a guiding hand to the most pressing of mortal affairs. The deck of the ship is a curious sight between the hours of half-past one and three. The tropical siesta requires no couching of the form. You sit down in your chair, with a book - you fade slowly into a deep, restful slumber. And yet it is a slumber wherein certain small pleasant things persist from the world outside. You remain dimly conscious of the rhythmic throbbing of the engines, of the beat of soft, warm air on your cheek.

At three o'clock or thereabout you rise as gently back to life; and sit erect in your chair without a stretch or a yawn in your whole anatomy. Then is the one time of day for a display of energy - if you have any to display. Ship games, walks fairly brisk - explorations to the forecastle, a watch for flying fish or Arab dhows, anything until tea time. Then the glowing sunset; the opalescent 


\section{THE RED SEA}

sea, and the soft afterglow of the sky - and the bugle summoning you to dress. That is a mean job. Nothing could possibly swelter worse than the tiny cabin. The electric fan is an aggravation. You reappear in your fresh "whites" somewhat warm and flustered in both mind and body. A turn around the deck cools you off; and dinner restores your equanimity - dinner with the soft, warm tropic air breathing through all the wide-open ports; the electric fans drumming busily; the men all in clean white; the ladies, the very few precious ladies, in soft, low gowns. After dinner the deck, as near cool as it will be, and bare heads to the breeze of our progress and glowing cigars. At ten or eleven o'clock the groups begin to break up, the canvas chairs to empty. Soon reappears a pajamaed figure followed by a steward carrying a mattress. This is spread, under its owner's direction, in a dark corner forward. With a sigh you in your turn plunge down into the sweltering inferno of your cabin, only to reappear likewise with a steward and a mattress. The latter, if you are wise, you spread where the wind of the ship's going will be full upon you. It is a strong wind and blows upon you heavily so that the sleeves and legs of your pajamas flop, but it is a soft, warm wind, and beats you as with muffled fingers. In no temperate clime can you ever enjoy 


\section{AFRICAN CAMP FIRES}

this peculiar effect, of a strong breeze on your naked skin without even the faintest surface chilly sensation. So habituated has one become to feeling cooler in a draught that the absence of chill lends the night an unaccustomedness, the more weird in that it is unanalyzed, so that one feels definitely that one is in a strange, far country. This is intensified by the fact that in these latitudes the moon, the great, glorious, calm tropical moon, is directly overheadfollows the centre line of the zenith - instead of, as with us in our temperate zone, always more or less declined to the horizon. This too lends the night an exotic quality, the more effective in that at first the reason for it is not apprehended.

A night in the tropics is always more or less broken. One awakens, and sleeps again. Motionless white-clad figures, cigarettes glowing, are lounging against the rail looking out over a molten sea. The moonlight lies in patterns across the deck, shivering slightly under the throb of the engines, or occasionally swaying slowly forward or slowly back as the ship's course changes, but otherwise motionless, for here the sea is always calm. You raise your head, look about, sprawl in a new position on your mattress, fall asleep. On one of these occasions you find unexpectedly that the velvet-gray night has become steel-gray dawn; and that the kindly old quarter- 


\section{THE RED SEA}

master is bending over you. Sleepily, very sleepily, you stagger to your feet and collapse into the nearest chair. Then to the swish of waters as the sailors sluice the decks all around and under you, you fall into a really deep sleep.

At six o'clock this is broken by chota-hahzari, another tropical institution, consisting merely of clear tea and crackers. I never could get to care for it, but nowhere in the tropics could I head it off. No matter how tired I was or how dead sleepy, I had to receive that confounded chota-hahzari. Throwing things at the native who brought it did no good at all. He merely dodged. Admonition did no good, nor prohibition in strong terms. I was but one white man of the whole white race; and I had no right to possess idiosyncrasies running counter to Distauri, the Custom. However, as the early hours are the profitable hours in the tropics, it did not drive me to homicide.

The ship's company now developed. Our two prize members fortunately for us, sat at our table. The first was the Swedish Professor aforementioned. He was large, benign, paternal, broad in mind, thoroughly human and beloved, and yet profoundly erudite. He was our iconoclast in the way of food; for he performed small but illuminating dissections on his plate, and announced triumphantly results 


\section{AFRICAN CAMP FIRES}

that were not a bit in accordance with the menu. A single bone was sufficient to take the pretension out of any fish. Our other particular friend was C., with whom later we travelled in the interior of Africa. C. is a very celebrated hunter and explorer, an old Africander, his face seamed and tanned by many years in a hard climate. For several days we did not recognize him, although he sat fairly alongside; but put him down as a shy man and let it go at that. He never stayed for the long table d'hote dinners; but fell upon the first solid course and made a complete meal from that. When he had quite finished eating all he could; he drank all he could; then he departed from the table, and took up a remote and inaccessible position in the corner of the smoking room. He was engaged in growing the beard he customarily wore in the jungle; a most fierce outstanding Mohammedan-looking beard that terrified the intrusive into submission. And yet Bwana C. possessed the kindest blue eyes in the world, full of quiet patience, great understanding and infinite gentleness. His manner was abrupt and uncompromising; but he would do anything in the world for one who stood in need of him. From women he fled; yet Billy won him with infinite patience, and in the event they became the closest of friends. Withal he possessed a pair of the most 


\section{THE RED SEA}

powerful shoulders I have ever seen on a man of his frame; and in the depths of his mild blue eyes flickered a flame of resolution that I could well imagine flaring up to something formidable. Slow to make friends, but staunch and loyal; gentle and forbearing, but fierce and implacable in action; at once loved and most terribly feared; shy as a wild animal, but straightforward and undeviating in his human relations; most remarkably quiet and unassuming, but with tremendous vital force in his deep eyes and forward-thrust jaw; informed with the widest and most understanding humanity, but unforgiving of evildoers; and with the most direct and absolute courage, Bwana $\mathrm{C}$. was to me the most interesting man I met in Africa, and became the best of my friends.

The only other man at our table happened to be, for our sins, the young Englishman mentioned as throwing the first coin to the old woman on the pier at Marseilles. We will call him Brown; and, because he represents a type, he is worth looking upon for a moment.

He was of the super-enthusiastic sort; bubbling over with vitality; in and out of everything; bounding up at odd and languid moments. To an extraordinary extent he was afflicted with the spiritual blindness of his class. Quite genuinely, quite 


\section{AFRICAN CAMP FIRES}

seriously, he was unconscious of the human significance of beings and institutions belonging to a foreign country or even to a class other than his own. His own kind he treated as complete and understandable human creatures. All others were merely objective. As we, to a certain extent, happened to fall in the former category, he was as pleasant to us as possible - that is, he was pleasant to us in his way, but had not insight enough to guess at how to be pleasant to us in our way. But as soon as he got out of his own class, or what he conceived to be such, he considered all people as "outsiders." He did not credit them with prejudices to rub, with feelings to hurt, indeed hardly with ears to overhear. Provided his subject was an "outsider" he had not the slightest hesitancy in saying exactly what he thought about any one, anywhere, always in his high, clear English voice, no matter what the time or occasion. As a natural corollary he always rebuffed beggars and the like brutally; and was always quite sublimely doing little things that thoroughly shocked our sense of the other fellow's rights as a human being. In all this he did not mean to be cruel nor inconsiderate. It was just the way he was built; and it never entered his head that "such people" had ears and brains.

In the rest of the ship's company were a dozen or 


\section{THE RED SEA}

so other Englishmen of the upper classes, either army men on shooting trips, or youths going out with some idea of settling in the country. They were a clean-built pleasant lot, good people to know anywhere; but of no unusual interest. It was only when one went abroad into the other nations that inscribable human interest could be found.

There was the Greek, Scutari, and his bride, a languorous rather opulent beauty, with large dark eyes for all men, and a luxurious manner of lying back and fanning herself. She talked, soft voiced, in half a dozen languages, changing from one to the other without a break in either her fluency or her thought. Her little lithe active husband sat around and adored her. He was apparently a very able citizen indeed, for he was going out to take charge of the construction work on a German Railway. To have filched so important a job from the German's themselves shows that he must have had ability. With them were a middle-aged Holland couple engaged conscientiously in travelling over the globe. They had been everywhere - the two American hemispheres, from one Arctic Sea to another, Siberia, China, the Malay Archipelago, this, that, and the other odd corner of the world. Always they sat placidly side by side, either in the saloon or on deck, smiling benignly, and conversing in spaced com- 


\section{AFRICAN CAMP FIRES}

fortable syllables with everybody who happened along. Mrs. Breemen worked industriously on some kind of feminine gear, and explained to all and sundry that she travelled "to see de sceenery wid my hoosband."

Also in this group was a small, wiry German Doctor who had lived for many years in the far interior of Africa, and was now returning after his vacation. He was a little man, bright-eyed and keen, with a clear complexion and hard flesh, in striking and agreeable contrast to most of his compatriots. The latter were trying to drink all the beer on the ship; but as she had been stocked for an eighty-day voyage, of which this was but the second week, they were not making noticeable headway. However, they did not seem to be easily discouraged. The Herr Doktor was most polite and attentive, but as we did not talk German nor much Swahili; and he had neither English nor much French, we had our difficulties. I have heard Billy in talking to him scatter fragments of these four languages through a single sentence!

For several days we drifted down a warm flat sea. Then one morning we came on deck to find ourselves close aboard a number of volcanic islands. They were composed entirely of red and dark purple lava blocks, rugged, quite without vegetation save for 


\section{THE RED SEA}

occasional patches of stringy green in a gully; and uninhabited except for a lighthouse on one, and a fishing shanty near the shores of another. The high, mournful mountains with their dark shadows seemed to brood over hot desolation. The rusted and battered stern of a wrecked steamer stuck up at an acute angle from the surges. Shortly after we picked up the shores of Arabia.

Note the advantages of a half ignorance. From early childhood we had thought of Arabia as the "burning desert" - flat, of course - and of the Red Sea as bordered by "shifting sands" alone. If we had known the truth - if we had not been half ignorant - we would have missed the profound surprise of discovering that in reality the Red Sea is bordered by high and rugged mountains, leaving just space enough between themselves and the shore for a sloping plain on which our glasses could make out occasional palms. Perhaps the "shifting sands of the burning desert" lie somewhere beyond; but somebody might have mentioned these great mountains! After examining them attentively we had to confess that if this sort of thing continued farther north, the children of Israel must have had a very hard time of it. Mocha shone white, glittering and low, with the red and white spire of a mosque rising brilliantly above it. 


\section{VI \\ ADEN}

T'T WAS cooler; and for a change we had turned into our bunks, when B. pounded on our stateroom door.

"In the name of the Eternal East," said he, "come on deck!"

We slipped on kimonos and joined the row of scantily draped and interested figures along the rail.

The ship lay quite still on a perfect sea of moonlight bordered by a low flat distant shore on one side, and nearer mountains on the other. A strong flare centred from two ship reflectors overside made a focus of illumination that subdued, but could not quench, the soft moonlight with which all outside was silvered. A dozen boats striving against a current or clinging as best they could to the ship's side glided in to the light and became real and solid; or dropped back into the ghostly white insubstantiability of the moon. They were long narrow boats, with small flush decks fore and aft. We looked down on them from almost directly above, so that 


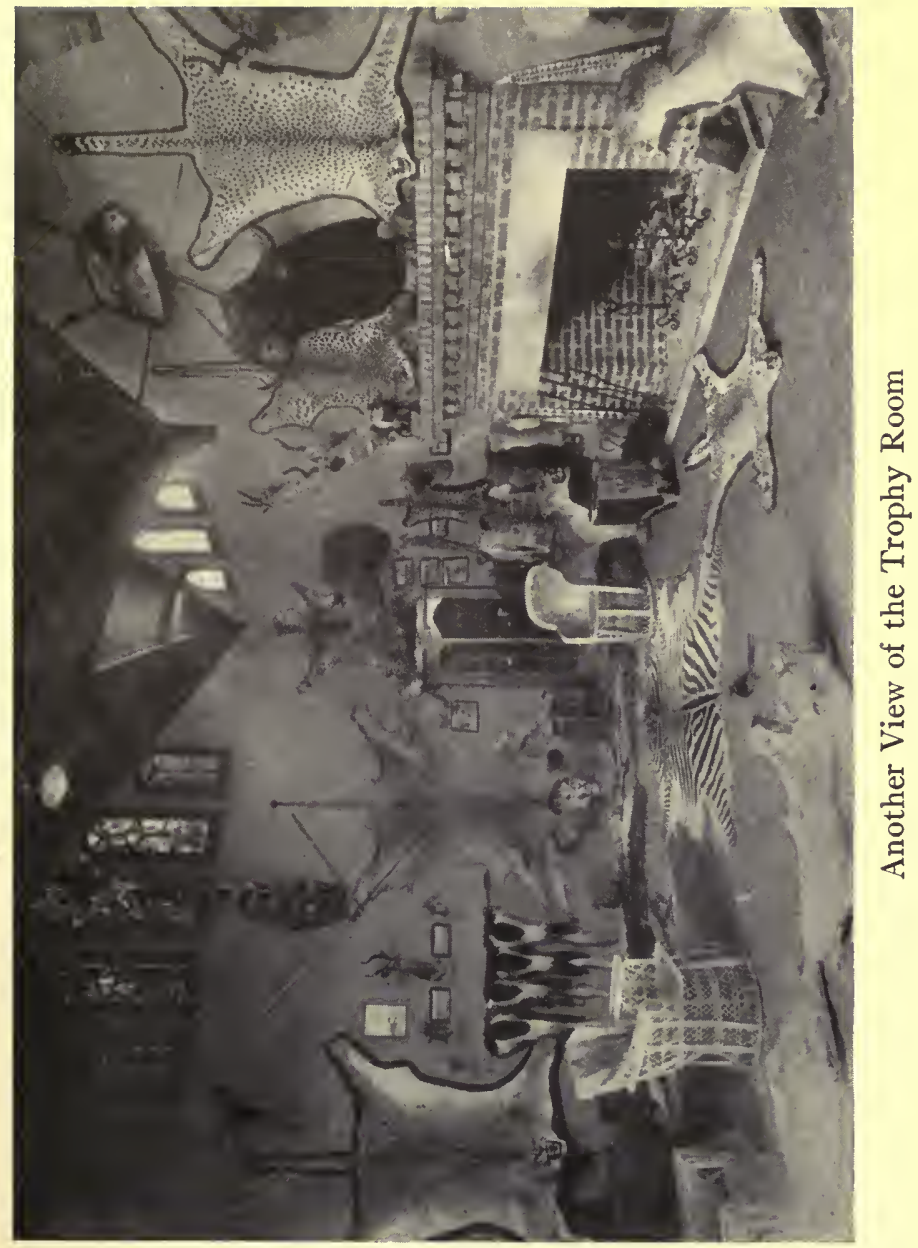




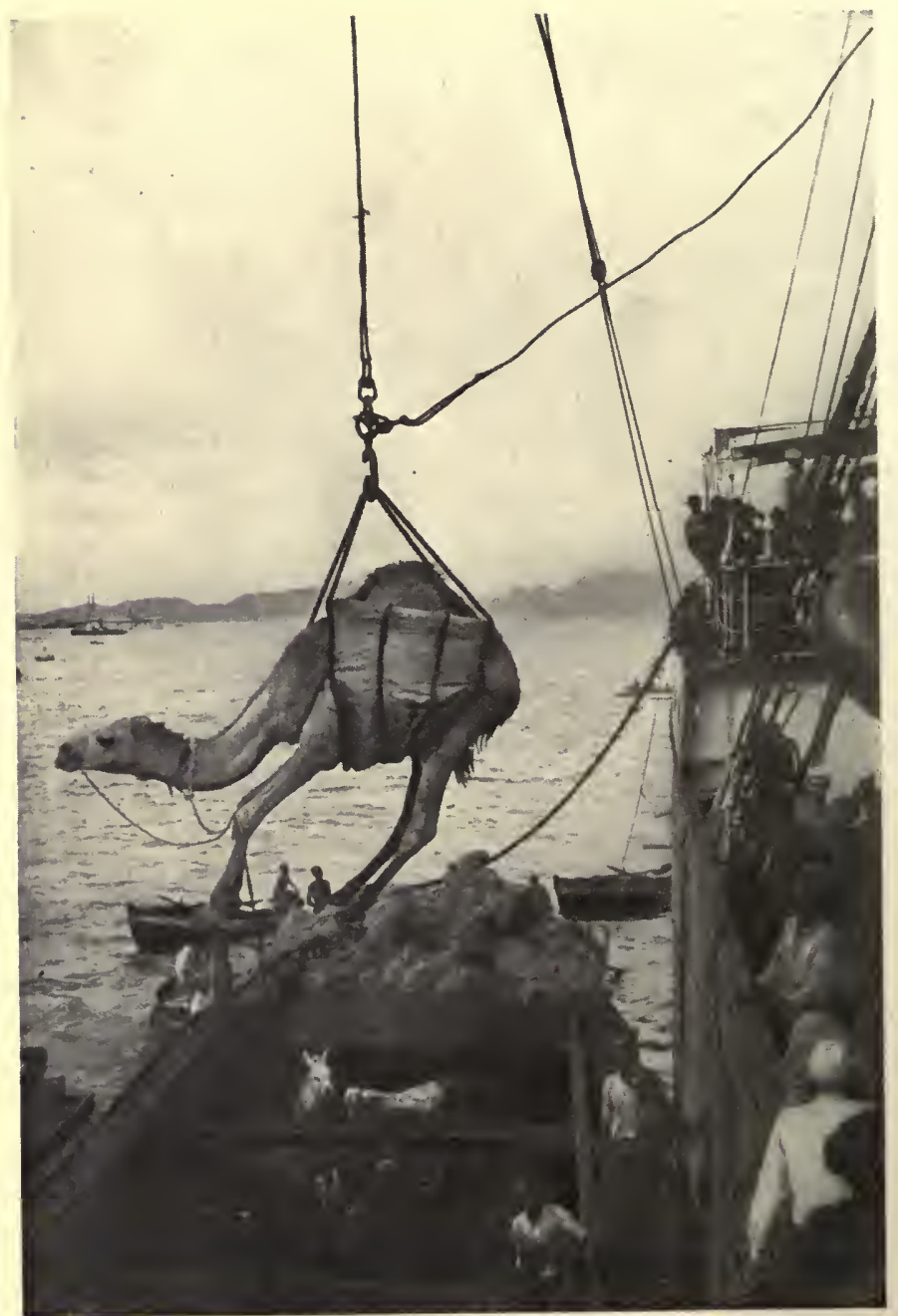

"We waited patiently to see the camels slung aboard by the crane" 


\section{$\mathrm{ADEN}$}

we saw the thwarts and the ribs and the things they contained.

Astern in each stood men, bending gracefully against the thrust of long sweeps. About their waists were squares of cloth, wrapped twice and tucked in. Otherwise they were naked, and the long smooth muscles of their slender bodies rippled under the skin. The latter was of a beautiful fine texture, and chocolate brown. These men had keen intelligent clear-cut faces, of the Greek order, as though the statues of a garden had been stained brown and had come to life. They leaned on their sweeps, thrusting slowly but strongly against the little wind and current that would drift them back.

In the body of the boats crouched, sat, or lay a picturesque mob. Some pulled spasmodically on the very long limber oars; others squatted doing nothing; some, huddled shapelessly underneath white cloths that completely covered them, slept soundly in the bottom. We took these for merchandise until one of them suddenly threw aside his covering and sat up. Others again poised in proud and graceful attitudes on the extreme prows of their bobbing craft. Especially decorative were two clad only in immense white turbans and white cloths about the waist. An old Arab with a white beard stood midships in one boat quite motionless except 


\section{AFRICAN CAMP FIRES}

for the slight swaying necessary to preserve his equilibrium, his voluminous white draperies fluttering in the wind, his dark face just distinguishable under his burnouse. Most of the men were Somalis, however. Their keen small faces, slender but graceful necks, slim, well-formed torsos bending to every movement of the boat, and the white or gaudy draped nether garments were as decorative as the figures on an Egyptian tomb. One or two of the more barbaric had made neat headdresses of white clay plastered in the form of a skullcap.

After an interval a small and fussy tugboat steamed around our stern and drew alongside the gangway. Three passengers disembarked from her and made their way aboard. The main deck of the craft under an awning was heavily encumbered with trunks, tin boxes, hand baggage, tin bathtubs, gun cases and all sorts of impedimenta. The tugboat moored itself to us fore and aft, and proceeded to think about discharging. Perhaps twenty men in accurate replica of those in the small boats had charge of the job. They had their own methods. After a long interval devoted strictly to nothing, some unfathomable impulse would incite one or two or three of the natives to tackle a trunk. At it they tugged and heaved and pushed in the manner of ants making off with a particularly large fly or 


\section{ADEN}

other treasure trove, teasing it up the steep gangway to the level of our decks. The trunks once safely bestowed, all interest, all industry died. We thought that finished it; and wondered why the tug did not pull out of the way. But always, after an interval, another bright idea would strike another native or natives. $\mathrm{He}$ - or they - would disappear beneath the canvas awning over the tug's deck, to emerge shortly carrying almost anything, from a parasol to a heavy chest.

On close inspection they proved to be a very small people. The impression of graceful height had come from the slenderness and justness of their proportions, the smallness of their bones, and the upright grace of their carriage. After standing alongside one, we acquired a fine respect for their ability to handle those trunks at all.

Moored to the other side of the ship we found two huge lighters from which bales of goods were being hoisted aboard. Two camels and a dozen diminutive mules stood in the waist of one of these craft. The camels were as sniffy and supercilious and scornful as camels always are; and everybody promptly hated them with the hatred of the abysmally inferior spirit for something that scorns it, as is the usual attitude of the human mind toward camels. We waited for upward of an hour in the 


\section{AFRICAN CAMP FIRES}

hope of seeing those camels hoisted aboard; but in vain. While we were so waiting one of the deck passengers below us, a Somali in white clothes and a gorgeous cerise turban decided to turn in. $\mathrm{He}$ spread a square of thin matting atop one of the hatches, and began to unwind yards and yards of the fine silk turban. He came to the end of it whisk! he sank to the deck; the turban, spread open by the resistance of the air, fluttered down to cover him from head to foot. Apparently he fell asleep at once, for he did not again move nor alter his position. $\mathrm{He}$, as well as an astonishingly large proportion of the other Somalis and Abyssinians we saw, carried a queer, well-defined, triangular wound in his head. It had long since healed, was an inch or so across, and looked as though a piece of the skull had been removed. If a conscientious enemy had leisure and an ice pick he would do just about that sort of a job. How its recipient had escaped instant death is a mystery.

At length, about three o'clock, despairing of the camels, we turned in.

After three hours, sleep we were again on deck. Aden by daylight seemed to be several sections of a town tucked into pockets in bold, raw, lava mountains that came down fairly to the water's edge. Between these pockets ran a narrow shore road; and along the 


\section{ADEN}

road paced haughty camels hitched to diminutive carts. On contracted round bluffs toward the sea were various low bungalow buildings which, we were informed, comprised the military and civil officers' quarters. The real Aden has been built inland a short distance at the bottom of a cup in the mountains. Elaborate stone reservoirs have been constructed to catch rain water, as there is no other natural water supply whatever. The only difficulty is that it practically never rains; so the reservoirs stand empty, the water is distilled from the sea, and the haughty camels and the little carts do the distributing.

The lava mountains occupy one side of the spacious bay or gulf. The foot of the bay and the other side are flat, with one or two very distant white villages, and many heaps of glittering salt as big as houses.

We waited patiently at the rail for an hour more to see the camels slung aboard by the crane. It was worth the wait. They lost their impassive and immemorial dignity completely, sprawling, groaning, positively shrieking in dismay. When the solid deck rose to them, and the sling had been loosened, however, they regained their poise instantaneously. Their noses went up in the air, and they looked about them with a challenging, unsmiling superiority, 


\section{AFRICAN CAMP FIRES}

as though to dare any one of us to laugh. Their native attendants immediately squatted down in front of them and began to feed them with convenient lengths of what looked like our common marsh cattails. The camels did not even then manifest the slightest interest in the proceedings. Indeed, they would not condescend to reach out three inches for the most luscious tidbit held that far from their aristocratic noses. The attendants had actually to thrust the fodder between their jaws. I am glad to say they condescended to chew. 


\section{VII}

\section{THE INDIAN OCEAN}

TEAVING Aden, and rounding the great prom1 ontory of Cape Gardafui, we turned south along the coast of Africa. Off the cape were strange, oily cross rips and currents on the surface of the sea; the flying fish rose in flocks before our bows; high mountains of peaks and flat table tops thrust their summits into clouds; and along the coast the breakers spouted like whales. For the first time, too, we began to experience what our preconceptions had imagined as tropical heat. Heretofore we had been hot enough, in all conscience, but the air had felt as though wafted from an opened furnace door - dry and scorching. Now, although the temperature was lower, ${ }^{*}$ the humidity was greater. A swooning languor was abroad over the spellbound ocean, a relaxing mist of enchantment. My glasses were constantly clouding over with a fine coating of water drops; exposed metal rusted overnight; the folds in garments accumulated mildew in an as-

${ }^{*} 82-88^{\circ}$ in daytime, and $75-83^{\circ}$ at night. 


\section{AFRICAN CAMP FIRES}

tonishingly brief period of time. There was never even the suggestion of chill in this dampness. It clung and enveloped like a grateful garment; and seemed only to lack sweet perfume.

At this time, by good fortune, it happened that the moon came full. We had enjoyed its waxing during our voyage down the Red Sea; but now it had reached its greatest phase, and hung over the slumbering tropic ocean like a lantern. The lazy sea stirred beneath it, and the ship glided on, its lights fairlysubdued by the splendour of the waters. Under the awnings the ship's company lounged in lazy attitudes or promenaded slowly, talking low voiced, cigars glowing in the splendid dusk. Overside, in the furrow of the disturbed waters, the phosphorescence flashed perpetually beneath the shadow of the ship.

The days passed by languidly and all alike. On the chart outside the smoking-room door the procession of tiny German flags on pins marched steadily, an inch at a time, toward the south. Otherwise we might as well have imagined ourselves midgets afloat in a pond and getting nowhere.

Somewhere north of the equator - before Father Neptune in ancient style had come aboard and ducked the lot of us - we were treated to the spectacle of how the German "sheep" reacts under 


\section{THE INDIAN OCEAN}

a joke. Each nation has its type of fool; and all, for the joyousness of mankind, differ. On the bulletin board one evening appeared a notice to the effect that the following morning a limited number of sportsmen would be permitted ashore for the day. Each was advised to bring his own lunch, rifle, and drinks. The reason alleged was that the ship must round a certain cape across which the sportsmen could march afoot in enough shorter time to permit them a little shooting.

Now aboard ship were a dozen English, four Americans, and thirty or forty Germans. The Americans and English looked upon that bulletin, smiled gently and went to order another round of lime squashes. It was a meek, mild, little joke enough; but surely the bulletin board was as far as it could possibly go. Next morning, however, we observed a half dozen of our German friends in khaki and sun helmet, very busy with lunch boxes, bottles of beer, rifles, and the like. They said they were going ashore as per bulletin. We looked at each other and hied us to the upper deck. There we found one of the boats slung overside, with our old friend the Quartermaster ostentatiously stowing kegs of water, boxes and the like.

"When," we inquired gently, "does the expedition start?" 


\section{AFRICAN CAMP FIRES}

“At ten o'clock," said he.

It was now within fifteen minutes of that hour. We were at the time fully ten miles off shore, and forging ahead full speed parallel with the coast.

We pointed out this fact to the Quartermaster, but found to our sorrow that the poor old man had suddenly gone deaf! We, therefore, refrained from asking several other questions that had occurred to us, such as, Why the cape was not shown on the map?

"Somebody," said one of the Americans, a cowboy going out second class on a look for new cattle country, "is a goat. It sure looks to me like it was these yere steamboat people. They can't expect to rope nothing on such a raw deal as this!"

To which the English assented, though in different idiom.

But now up the companion ladder struggled eight serious-minded individuals herded by the second mate. They were armed to the teeth and thoroughly equipped with things I had seen in German catalogues, but in whose existence I had never believed. A half-dozen sailors eagerly helped them with their multitudinous effects. Not a thought gave they to the fact that we were ten miles off the coast, that we gave no indication of slackening speed, that it would take the rest of the day to row ashore, that 


\section{THE INDIAN OCEAN}

there was no cape for us to round, that if there were - oh! all the other hundred improbabilities peculiar to the situation. Under direction of the mate they deposited their impedimenta beneath a tarpaulin, and took their places in solemn rows amidships across the thwarts of the boat slung overside. The importance of the occasion sat upon them heavily; they were going ashore - in Africa - to Slay Wild Beasts. They looked upon themselves as of bolder, sterner stuff than the rest of us.

When the procession first appeared, our cowboy's face for a single instant had flamed with amazed incredulity. Then a mask of expressionless stolidity fell across his features, which in no line thereafter varied one iota.

"What are they going to do with them?" murmured one of the Englishmen, at a loss.

"I reckon," said the cowboy, "that they look on this as the easiest way to drown them all to onct."

Then from behind one of the other boats suddenly appeared a huge German sailor with a hose. The devoted imbeciles in the shore boat were drenched as by a cloudburst. Back and forth and up and down the heavy stream played, while every other human being about the ship shrieked with joy. Did the victims rise up in a body and capture that 


\section{AFRICAN CAMP FIRES}

hose nozzle and turn the stream to sweep the decks? Did they duck for shelter? did they at least know enough to scatter and run? They did none of these things; but sat there in meek little rows like mannikins until the boat was half full of water and everything awash. Then, when the sailor shut off the stream, they continued to sit there until the mate came to order them out. Why? I cannot tell you. Perhaps that is the German idea of how to take a joke. Perhaps they were afraid worse things might be consequent on resistance. Perhaps they still hoped to go ashore. One of the Englishmen asked just that question.

"What," he demanded disgustedly, "what is the matter with the beggars?"

Our cowboy may have had the correct solution. He stretched his long legs and jumped down from the rail.

"Nothing stirring above the ears," said he.

It is customary in books of travel to describe this part of the journey about as follows: "skirting the low and uninteresting shores of Africa we at length reached," etc. Low and uninteresting shores! Through the glasses we made out distant mountains far beyond nearer hills. The latter were greencovered with dense forests whence rose mysterious smokes. Along the shore we saw an occasional 


\section{THE INDIAN OCEAN}

coconut plantation to the water's edge and native huts and villages of thatch. Canoes of strange models lay drawn up on shelving beaches; queer fish-pounds of brush reached out considerable distances from the coast. 'The white surf pounded on a yellow beach.

All about these things was the jungle, hemming in the plantations and villages, bordering the lagoons, creeping down until it fairly overhung the yellow beaches; as though, conqueror through all the country beyond, it were half-inclined to dispute dominion with old Ocean himself. It looked from the distance like a thick, soft coverlet thrown down over the country; following, or, rather, suggesting, the inequalities. Through the glasses we were occasionally able to peek under the edge of this coverlet, and see where the fringe of the jungle drew back in a little pocket, or to catch the sheen of mysterious dark rivers slipping to the sea. Up these dark rivers, by way of the entrances of these tiny pockets, the imagination then could lead on into the dimness beneath the sunlit upper surfaces.

Toward the close of one afternoon we changed our course slightly and swung in on a long slant toward the coast. We did it casually; too casually for so very important an action, for now at last we were about to touch the mysterious continent. 


\section{AFRICAN CAMP FIRES}

Then we saw clearer the fine, big groves of palm and the luxuriance of the tropical vegetation. Against the greenery, bold and white, shone the buildings of Mombasa; and after a little while more we saw an inland glitter that represented her narrow, deep bay, the stern of a wreck against the low, green cliffs, and strange, fat-trunked squat trees without leaves. Straight past all this we glided at half speed, then turned sharp to the right to enter a long, wide expanse, like a river with green banks, twenty feet or so in height, grown thickly with the tall coconut palms. These gave way at times into broad, low lagoons, at the end of which were small beaches and boats, and native huts among more coconut groves. Through our glasses we could see the black men watching us, quite motionless, squatted on their heels.

It was like suddenly entering another world, this gliding from the open sea straight into the heart of a green land. The ceaseless wash of waves we had left outside with the ocean; our engines had fallen silent. Across the hushed waters came to us strange chantings and the beating of a tom-tom, an occasional shrill shout from the unknown jungle. The sun was just set, and the tops of the palms caught the last rays; all below was dense green shadow. Across the surface of the water glided dugout canoes of shapes strange to us. We passed 


\section{THE INDIAN OCEAN}

ancient ruins almost completely dismantled, their stones half-smothered in green rank growth. The wide riverlike bay stretched on before us as far as the waning light permitted us to see; finally losing itself in the heart of mystery.

Steadily and confidently our ship steamed forward, until at last, when we seemed to be afloat in a land-locked lake, we dropped anchor and came to rest.

Darkness fell utterly before the usual quarantine regulations had been carried through. Active and efficient agents had already taken charge of our affairs, so we had only to wait idly by the rail until summoned. Then we jostled our way down the long gangway, passed and repassed by natives carrying baggage or returning for more baggage, stepped briskly aboard a very bobby little craft, clambered over a huge pile of baggage, and stowed ourselves as best we could. A figure in a long white robe sat astern, tiller ropes in hand; two half-naked blacks far up toward the prow manipulated a pair of tremendous sweeps. With a vast heaving, jabbering, and shouting our boat disengaged itself from the swarm of other craft. We floated around the stern of our ship - and were immediately suspended in blackness dotted with the stars and their reflections and with various, twinkling, scattered lights. To one 


\section{AFRICAN CAMP FIRES}

of these we steered; and presently touched at a stone quai with steps. At last we set foot on the land to which so long we had journeyed and toward which so great our expectations had grown. We experienced "the pleasure that touches the souls of men landing on strange shores." 


\section{VIII}

\section{MOMBASA}

SINGLE light shone at the end of the stone
$\mathbf{1}$ quai, and another inside a big indeterminate building at some distance. We stumbled toward this, and found it to be the biggest shed ever constructed out of corrugated iron. A bearded Sikh stood on guard at its open entrance. He let any one and every one enter, with never a flicker of his expressionless black eyes; but allowed no one to go out again without the closest scrutiny for dutiable articles that lacked the blue customs paster. We entered. The place was vast and barnlike and dim, and very, very hot. A half-dozen East Indians stood behind the counters; another, a babu, sat at a little desk ready to give his clerical attention to what might be required. We saw no European; but next morning found that one passed his daylight hours in this inferno of heat. For the moment we let our main baggage go, and occupied ourselves only with getting through our smaller effects. This accomplished, we stepped out past the Sikh into the grateful night. 


\section{AFRICAN CAMP FIRES}

We had as guide a slender and wiry individual clad in tarboosh and long white robe. In a vague general way we knew that the town of Mombasa, was across the island and about four miles distant. In what direction or how we got there we had not the remotest idea.

The guide set off at a brisk pace with which we tried in vain to keep step. He knew the ground, and we did not; and the night was black-dark. Commands to stop were of no avail whatever; nor could we get hold of him to restrain him by force. When we put on speed he put on speed too. His white robe glimmered ahead of us just in sight; and in the darkness other white robes, passing and crossing, glimmered also. At first the ground was rough, so that we stumbled outrageously. Billy and $B$. soon fell behind, and I heard their voices calling plaintively for us to slow down a bit.

"If I ever lose this nigger I'll never find him again," I shouted back, "but I can find you. Do the best you can!"

We struck a smoother road that led up a hill on a long slant. Apparently for miles we followed thus, the white-robed individual ahead still deaf to all commands and the blood-curdling threats I had now come to uttering. All our personal baggage had long since mysteriously disappeared, ravished 


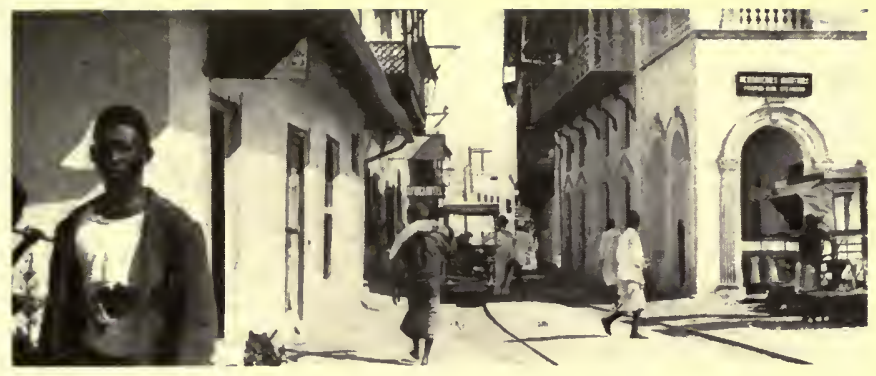

Vasco da Gama Street, the principal thoroughfare of Mombasa

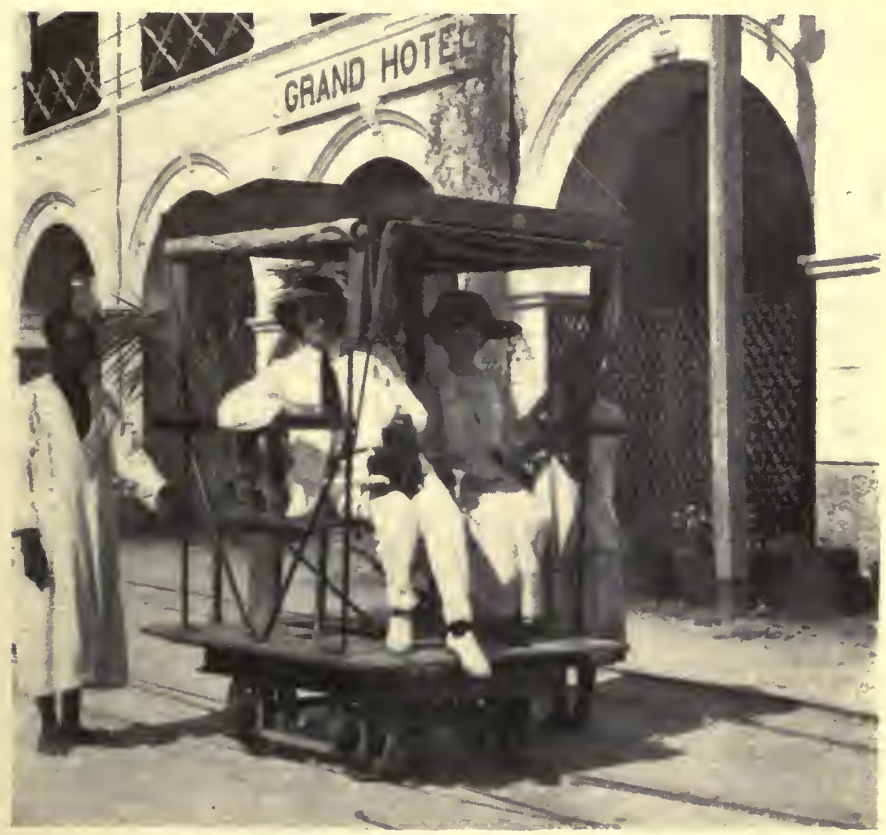

The trolley car of Mombasa 


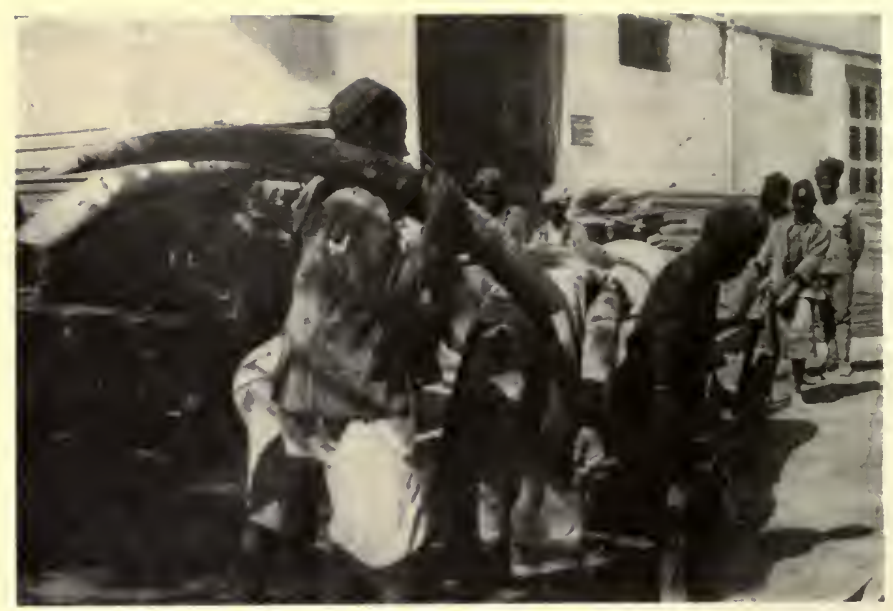

In the Ivory market of Mombasa

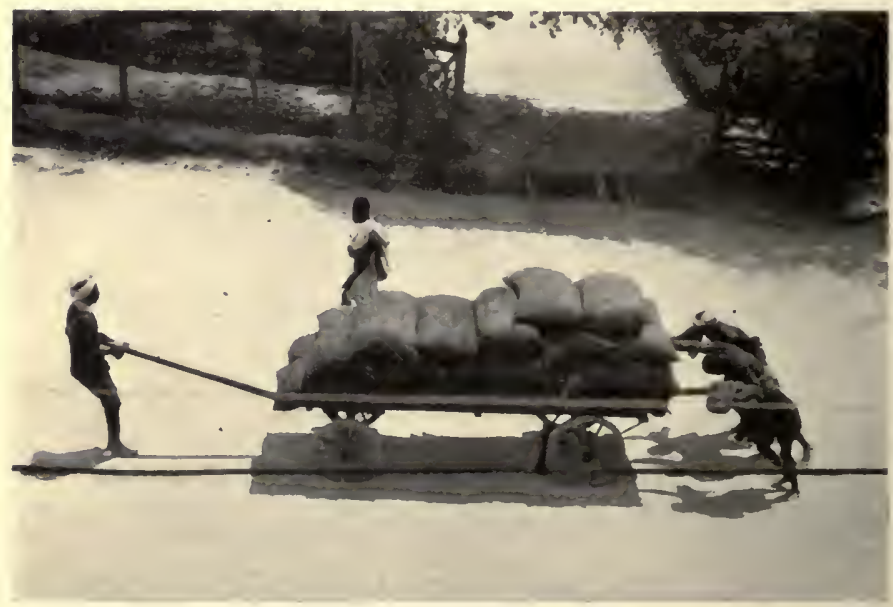

The labour of Africa is carried forward by song 


\section{MOMBASA}

away from us at the customs house by a ragged horde of blacks. It began to look as though we were stranded in Africa without baggage or effects. Billy and B. were all the time growing fainter in the distance, though evidently they too had struck the long, slanting road.

Then we came to a dim, solitary lantern glowing feebly beside a bench at what appeared to be the top of the hill. Here our guide at last came to a halt and turned to me a grinning face.

"Samama hapa," he observed.

There! That was the word I had been frantically searching my memory for! Samama - stop!

The others struggled in. We were very warm. Up to the bench led a tiny car track, the rails not over two feet apart, like the toy railroads children use. This did not look much like grown-up transportation, but it and the bench and the dim lantern represented all the visible world.

We sat philosophically on the bench and enjoyed the soft tropical night. The air was tepid, heavy with unknown perfume, black as a band of velvet across the eyes, musical with the subdued undertones of a thousand thousand night insects. At points overhead the soft, blind darkness melted imperceptibly into stars.

After a long interval we distinguished a distant 6I 


\section{AFRICAN CAMP FIRES}

faint rattling, that each moment increased in loudness. Shortly came into view along the narrow tracks a most extraordinary vehicle. It was a small square platform on wheels across which ran a bench seat, and over which spread a canopy. It carried also a dim lantern. This rumbled up to us and stopped. From its stern hopped two black boys. Obeying a smiling invitation, we took our places on the bench. The two boys immediately set to pushing us along the narrow track.

We were off at an astonishing speed through the darkness. The night was deliciously tepid; and, as I have said, absolutely dark. We made out the tops of palms and the dim loom of great spreading trees, and could smell sweet, soft odours. The bareheaded, lightly clad boys pattered alongside whenever the grade was easy, one hand resting against the rail; or pushed mightily up little hills; or clung alongside like monkeys while we rattled and swooped and plunged down hill into the darkness. Subsequently we learned that a huge flat beam projecting amidships from beneath the seat operated a brake which we above were supposed to manipulate; but being quite ignorant as to the ethics and mechanics of this strange street-car system, we swung and swayed at times quite breathlessly.

After about fifteen minutes we began to pick up 


\section{MOMBASA}

lights ahead, then to pass dimly seen garden walls with trees whose brilliant flowers the lantern revealed fitfully. At last we made out white stucco houses; and shortly drew up with a flourish before the hotel itself.

This was a two-story stucco affair, with deep verandas sunken in at each story. It fronted a wide white street facing a public garden; and this, we subsequently discovered, was about the only clear and open space in all the narrow town. Antelope horns were everywhere hung on the walls; and teakwood easy chairs with rests on which comfortably to elevate your feet above your head stood all about. We entered a bare brick-floored diningroom, and partook of tropical fruits quite new to us - papayas, mangoes, custard apples, pawpaws, and the small red eating bananas too delicate for export. Overhead the punkahs swung back and forth in lazy hypnotic rhythm. We could see the two blacks at the ends of the punkah cords outside on the veranda, their bodies swaying lithely in alternation as they threw their weight against the light ropes. Other blacks, in the long white robes and exquisitely worked white skullcaps of the Swahili, glided noiselessly on bare feet, serving.

After dinner we sat out until midnight in the teakwood chairs of the upper gallery, staring through 


\section{AFRICAN CAMP FIRES}

the arches into the black, mysterious night, for it was very hot; and we rather dreaded the necessary mosquito veils as likely to prove stuffy. The mosquitoes are few in Mombasa, but they are very, very deadly. At midnight the thermometer stood $87^{\circ} \mathrm{F}$.

Our premonitions as to stuffiness were well justified. After a restless night we came awake at daylight to the sound of a fine row of some sort going on outside in the streets. Immediately we arose, threw aside the lattices, and hung out over the sill.

The chalk-white road stretched before us. Opposite was a public square grown with brilliant flowers, and flowering trees. We could not doubt the cause of the trouble. An Indian on a bicycle, hurrying to his office, had knocked down a native child. Said child, quite naked, sat in the middle of the white dust and howled to rend the heavens whenever he felt himself observed. If, however, the attention of the crowd happened for the moment to be engrossed with the babu, the injured one sat up straight and watched the row with interested rolling pickaninny eyes. A native policeman made the centre of a whirling, vociferating group. He was a fine-looking chap, straight and soldierly, dressed in red tarboosh, khaki coat bound close around the 


\section{MOMBASA}

waist by yards and yards of broad red webbing, loose, short drawers of khaki, bare knees and feet, and blue puttees between. His manner was inflexible. The babu jabbered excitedly; telling, in all probability, how he was innocent of fault, was late for his work, etc. In vain. He had to go; also the kid, who now, seeing himself again an object of interest, recommenced his howling. Then the babu began frantically to indicate members of the crowd whom he desired to retain as witnesses. Evidently not pleased with the prospect of appearing in court, those indicated promptly ducked and ran. The policeman as promptly pursued and collared them one by one. He was a long-legged policeman, and he ran well. The moment he laid hands on a fugitive, the latter collapsed; whereupon the policeman dropped him and took after another. The joke of it was that the one so abandoned did not try again to make off, but stayed as though he had been tagged at some game. Finally the whole lot, still vociferating, moved off down the white road.

For over an hour we hung from our window sill thoroughly interested and amused by the varied life that deployed before our eyes. The morning seemed deliciously cool after the hot night, although the thermometer stood $79^{\circ}$. The sky was very blue, with big piled white clouds down near the horizon. 


\section{AFRICAN CAMP FIRES}

Dazzling sun shone on the white road, the white buildings visible up and down the street, the white walls enclosing their gardens, and the greenery and colours of the trees within them. For from what we could see from our window we immediately voted tropical vegetation quite up to advertisement. Whole trees of gaudy red or yellow or bright orange blossoms, flowering vines, flowering shrubs, peered over the walls or through the fences; and behind them rose great mangoes or the slenderer shafts of bananas and coconut palms.

$\mathrm{Up}$ and down wandered groups of various sorts of natives. A month later we would have been able to identify their different tribes and to know more about them; but now we wondered at them as strange and picturesque peoples. They impressed us in general as being a fine lot of men, for they were of good physique, carried themselves well, and looked about them with a certain dignity and independence, a fine, free pride of carriage and of step. This fact alone differentiated them from our own negroes; but, further, their features were in general much finer, and their skins of a clear mahogony beautiful in its satiny texture. Most - and these were the blackest - wore long white robes and fine openwork skullcaps. They were the local race, the Swahili, had we but known it; the original "Zanzibari" who 


\section{MOMBASA}

furnished Livingstone, Stanley, Speke, and the other early explorers with their men. Others, however, were much less "civilized." We saw one "Cook's tour from the jungle" consisting of six savages, their hair twisted into innumerable points, their ear lobes stretched to hang fairly to their shoulders wearing only a rather neglectful blanket, adorned with polished wire, carrying war clubs and bright spears. They followed, with eyes and mouths open, a very sophisticated-looking city cousin in the usual white garments, swinging a jaunty, light bamboo cane. The cane seems to be a distinguishing mark of the leisure class. It not only means that you are not working; but also that you have no earthly desire to work.

About this time one of the hotel boys brought the inevitable chota-hahzari-the tea and biscuits of early morning. For this once it was very welcome.

Our hotel proved to be on the direct line of freighting. There are no horses or draught animals in Mombasa; the fly is too deadly. Therefore all hauling is done by hand. The tiny tracks of the unique street-car system run everywhere any one would wish to go; branching off even into private grounds and to the very front doors of bungalows situated far out of town. Each resident owns his own street car just as elsewhere a man has his 


\section{AFRICAN CAMP FIRES}

own carriage. There are of course public cars also, each with its pair of boys to push it; and also a number of rather decrepit rickshaws. As a natural corollary to the passenger traffic, the freighting also is handled by the blacks on large flat trucks with short guiding poles. These men are quite naked save for a small loin cloth, are beautifully shaped, and glisten all over from the perspiration shining in the sun. So fine is the texture of their skins, the softness of their colour, so rippling the play of muscles, that this shining perspiration is like a beautiful polish. They push from behind slowly and steadily and patiently and unwaveringly the most tremendous loads of the heaviest stuffs. When the hill becomes too steep for them, they turn their backs against the truck; and by placing one foot behind the other, a few inches at a time, they edge their burden up the slope.

The steering is done by one man at the pole or tongue in front. This individual also sets the key to the song by which in Africa all heavy labour is carried forward. He cries his wavering shrill-voiced chant; the toilers utter antiphony in low gruff tones. At a distance one hears only the wild high syncopated chanting; but as the affair draws slowly nearer, he catches the undertone of the responses. These latter are cast in the regular swing and rhythm of 


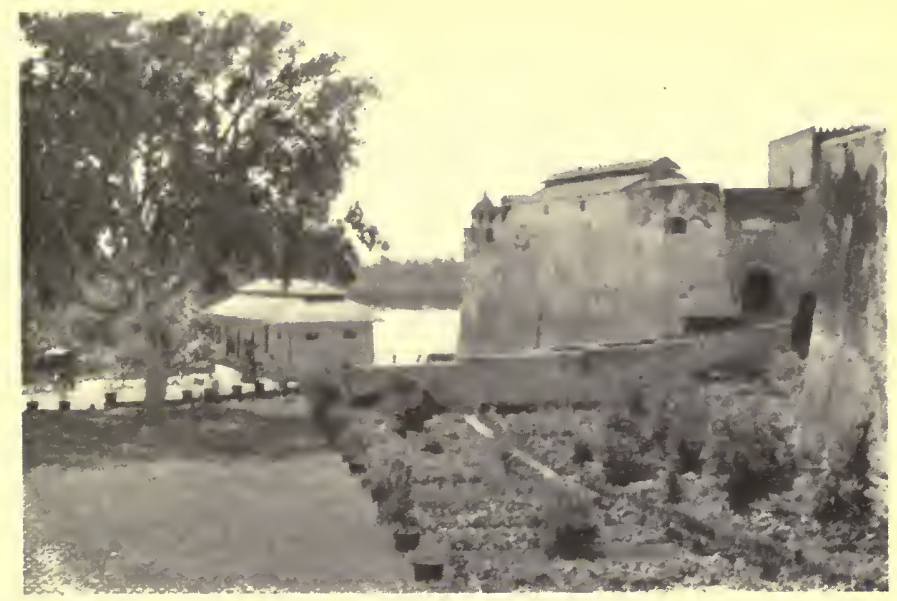

Old Portuguese fort at Mombasa

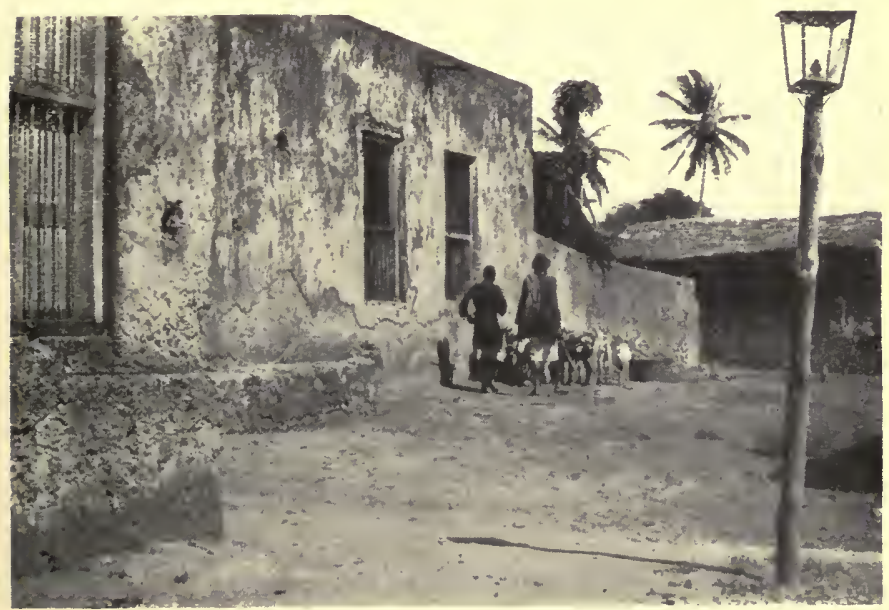

In the Arab quarter of Mombasa 


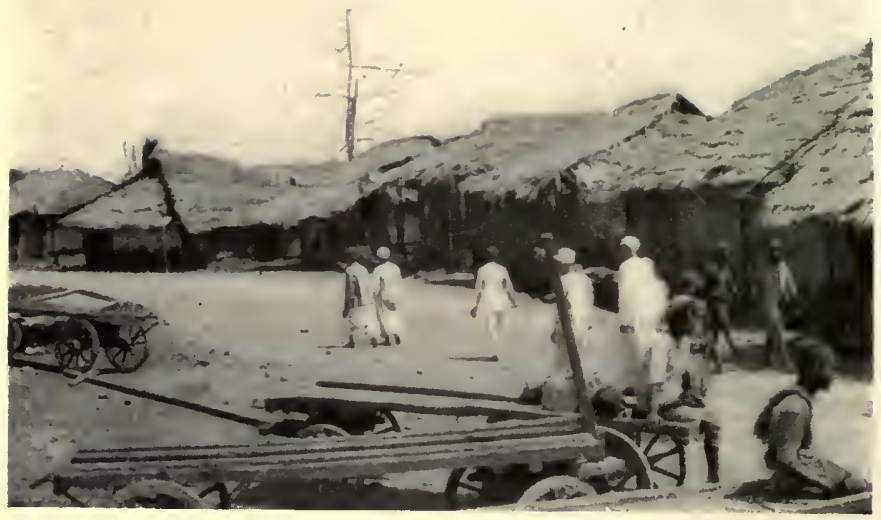

In the Swahili quarter of Mombasa

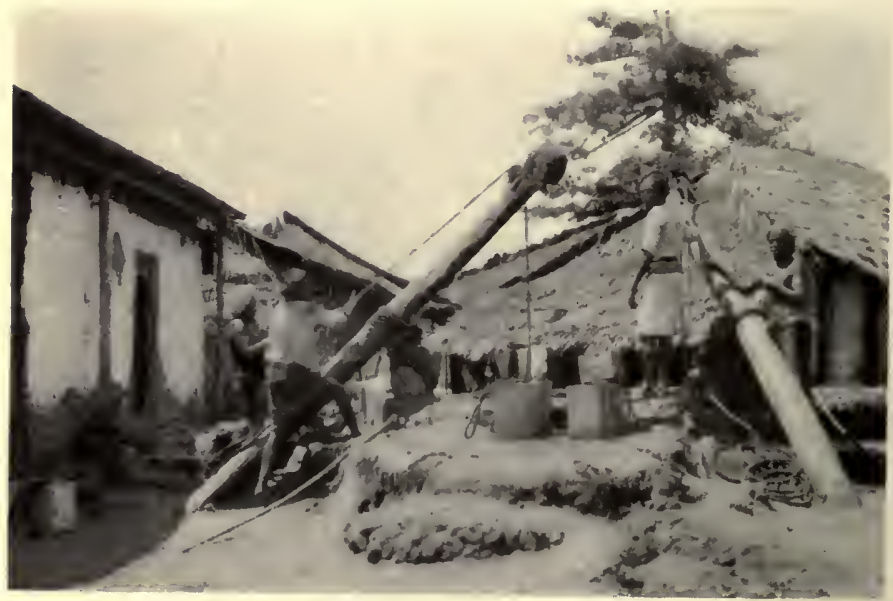

The entire water supply of Mombasa is drawn from numberless picturesque wells 


\section{MOMBASA}

effort; but the steersman throws in his bit at odd and irregular intervals. Thus:

Headman (shrill): "Hay ah mon!"

Pushers (gruff in rhythm): Tunk! - tunk! tunk! - "or:

Headman (shrill and wavering minor chant): "Ah-nah - nee - e-e-e!"

Pushers (undertone): "Umbwa-jo-e! Umbwajo-e!"

These wild and barbaric chantings - in the distance; near at hand, dying into distance again, slow, dogged, toilsome - came to be to us one of the typical features of the place.

After breakfast we put on our sun helmets and went forth curiously to view the town. We found it roughly divided into four quarters - the old Portuguese, the Arabic, the European, and the native. The Portuguese comprises the outer fringe next the waterfront of the inner bay. It is very narrow of street, with whitewashed walls, balconies, and wonderful carven and studded doors. The business of the town is done here. The Arabic quarter lies back of it - a maze of narrow alleys winding aimlessly here and there between high white buildings, with occasionally the minarets and towers of a mosque. This district harbours beside the upper class Swahilis and Arabs a large number of East 


\section{AFRICAN CAMP FIRES}

Indians. Still back of this are thousands of the low grass, or mud and wattle huts of the natives, their roofs thatched with straw or palm. These are apparently arranged on little system. The small European population lives atop the sea bluffs beyond the old fort in the most attractive bungalows. This, the most desirable location of all, has remained open to them because heretofore the fierce wars with which Mombasa, "the Island of Blood," has been swept have made the exposed seaward lands impossible.

No idle occupation can be more fascinating than to wander about the mazes of this ancient town. The variety of race and occupation is something astounding. Probably the one human note that, everywhere persisting, draws the whole together is furnished by the water-carriers. Mombasa has no water system whatever. The entire supply is drawn from numberless picturesque wells scattered everywhere in the crowded centre; and distributed mainly in Standard Oil cans suspended at either end of a short pole. By dint of constant daily exercise, hauling water up from a depth and carrying it various distances, these men have developed the most beautifully powerful figures. They proceed at a half trot, the slender poles, with forty pounds at either end, seeming fairly to cut into their naked 


\section{MOMBASA}

shoulders, muttering a word of warning to the loiterers at every other breath - seméelay! seméelay! No matter in what part of Mombasa you may happen to be, or at what hour of the day or night, you will meet these industrious little men trotting along under their burdens.

Everywhere also are the women, carrying themselves proudly erect, with a free swing of the hips. They wear invariably a single sheet of cotton cloth printed in blue or black with the most astonishing borders and spotty designs. This is drawn tight just above the breasts, leaving the shoulders and arms bare. Their hair is divided into perhaps a dozen parts running lengthwise of the head from the forehead to the nape of the neck, after the manner of the stripes on a watermelon. Each part then ends in a tiny twisted pigtail not over an inch long. The lobes of their ears have been stretched until they hold thick round disks about three inches in diameter, ornamented by concentric circles of different colours, with a red bull's eye for a centre. The outer edges of the ears are then further decorated with gold clasps set closely together. Many bracelets, necklaces, and armlets complete the get-up. They are big women, with soft velvety skins, and a proud and haughty carriage; the counterparts of the men in the white robes and caps. 


\section{AFRICAN CAMP FIRES}

By the way, it may be a good place here to remark that these garments, and the patterned squares of cloth worn by the women, are invariably most spotlessly clean.

These, we learned, were the Swahilis, the ruling class, the descendents of the slave traders. Beside them are all sorts and conditions. Your true savage pleased his own fancy as to dress and personal adornment. The bushmen generally shaved the edges of their wool to leave a nice close-fitting natural skullcap, wore a single blanket draped from one shoulder, and carried a war club. The ear lobe seemed always to be stretched; sometimes sufficiently to have carried a pint bottle. Indeed, white marmalade jars seemed to be very popular wear. One ingenious person had acquired a dozen of the sort of safety pins used to fasten curtains to their rings. These he had snapped into the lobes, six on a side.

We explored for some time. One of the Swahilis attached himself to us so unobtrusively that before we knew it we had accepted him as guide. In that capacity he realized an ideal, for he never addressed a word to us, nor did he even stay in sight. We wandered along at our sweet will, dawdling as slowly as we pleased. The guide had apparently quite disappeared. Look where we would we could in no manner discover him. At the next corner we 


\section{MOMBASA}

would pause, undecided as to what to do; there in the middle distance would stand our friend, smiling. When he was sure we had seen him and were about to take the turn properly, he would disappear again. Convoyed in this pleasant fashion we wound and twisted up and down and round and about through the most appalling maze. We saw the native markets with their vociferating sellers seated cross-legged on tables behind piles of fruit or vegetables, while an equally vociferating crowd surged up and down the aisles. Gray parrots and little monkeys perched everywhere about. Billy gave one of the monkeys a banana. He peeled it exactly as a man would have"done, smelled of it critically, and threw it back at her in the most insulting fashion. We saw also the rows of Hindu shops open to the street with their gaudily dressed children of blackened eyelids, their stolid dirty proprietors, and their women marvellous in bright silks and massive bangles. In the thatched native quarter were more of the fine Swahili women sitting cross-legged on the earth under low verandas, engaged in different handicrafts; and chickens; and many amusing naked children. We made friends with many of them, communicating by laughter and by signs, while our guide stood unobtrusively in the middle distance waiting for us to come on.

Just at sunset he led us out to a great open space, 


\section{AFRICAN CAMP FIRES}

with a tall palm in the centre of it and the gathering of a multitude of people. A muzzein was clambering into a high scaffold built of poles, whence shortly he began to intone a long-drawn-out "Allah! Allah! il Allah!" The coconut palms cut the sunset, and the boabab trees - the fat, lazy boababs - looked more monstrous than ever. We called our guide and conferred on him the munificient sum of sixteen and a half cents; with which, apparently much pleased, he departed. Then slowly we wandered back to the hotel. 


\section{PART II}

THE SHIMBA HILLS 



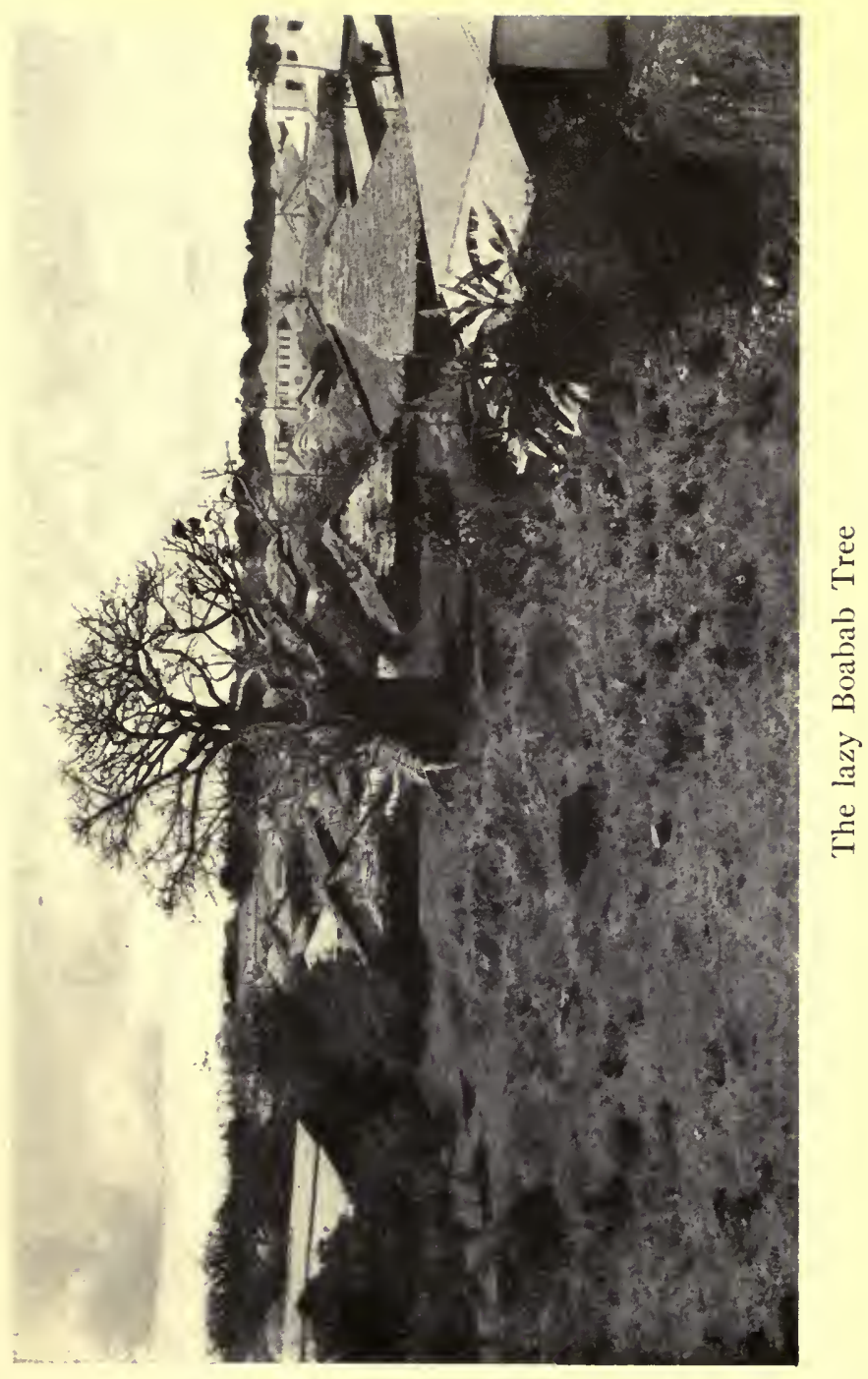




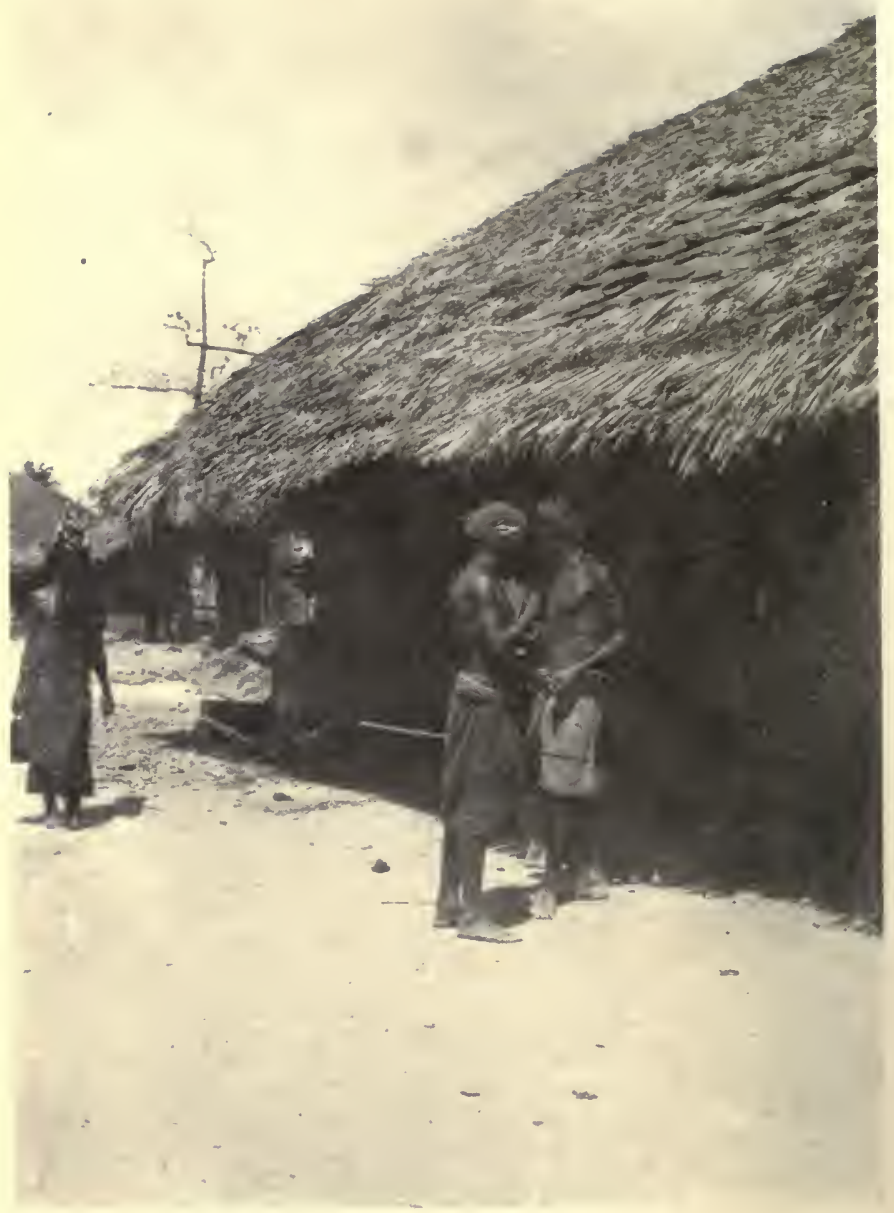

In the native quarter of Mombasa 


\section{IX}

\section{A TROPICAL JUNGLE}

M

ANY months later, and after adventures elsewhere described, ${ }^{*}$ besides others not relevant for the moment, F., an Englishman, and I returned to Mombasa. We came from some hundred odd miles in the interior where we had been exploring for the sources and the course of the Tsavo River. Now our purpose was to penetrate into the low, hot wooded country along the coast known as the Shimba Hills in quest of a rare beast called the sable antelope.

These hills could be approached in one of two ways - by crossing the harbour, and then marching two days afoot; or by voyaging up to the very end of one of the long arms of the sea that extend many miles inland. The latter involved dhows; dependence on uncertain winds; favourable tides and a heap of good luck. It was less laborious but most uncertain. At this stage of the plan the hotel manager came forward with the offer of a gasoline launch, which we gladly accepted.

"Land of Footprints" 


\section{AFRICAN CAMP FIRES}

We embarked about noon, storing our native carriers and effects aboard a dhow hired for the occasion. This we purposed towing. A very neatly uniformed Swahili bearing on his stomach a highly polished brass label as big as a door plate - "Harbour Police" - threw duck fits over what he called overloading the boat. He knew very little about boats, but threw very competent duck fits. As we did know something about boats we braved unknown consequences by disregarding him utterly. No consequences ensued; unless perhaps to his own health. When everything was aboard, that dhow was pretty well down, but still well afloat. Then we white men took our places in the launch.

This was a long narrow affair with a four-cylinder thirty-horsepower engine. As she possessed no speed gears, she had either plunge ahead full speed or come to a stop; there were no compromises. Her steering was managed by a tiller instead of a wheel; so that a mere touch sufficed to swerve her ten feet from her course. As the dhow was in no respect built on such nervous lines, she did occasionally some fancy and splashing curves.

The pilot of the launch turned out to be a sandyhaired Yankee who had been catching wild animals for Barnum \& Bailey's Circus. While waiting for his ship, he, being a proverbial handy Yankee, had 


\section{A TROPICAL JUNGLE}

taken on this job. He became quite interested in telling us this, and at times forgot his duties at the tiller. Then that racing-launch would take a wild swoop; the clumsy old dhow astern would try vainly, with much spray and dangerous careening, to follow; the compromise course would all but upset her; the spray would fly; the safari boys would take their ducking; the boat boys would yell and dance and lean frantically against the two long sweeps with which they tried to steer. In this wild and untrammelled fashion we careered up the bay, too interested in our own performances to pay much attention to the scenery. The low shores, with their coconut groves gracefully rising above the mangrove tangle, slipped by; and the distant, blue Shimba Hills came nearer.

After a while we turned into a narrower channel with a good many curves, and a quite unknown depth of water. Down this we whooped at the full speed of our thirty-horsepower engine. Occasional natives, waist deep and fishing, stared after us bung-eyed. The Yankee ventured a guess as to how hard she would hit on a mudbank. She promptly proved his guess a rank underestimate by doing so. We fell in a heap on the bottom. The dhow bore down on us with majestic momentum. The boat boys leaned frantically on their sweeps and 


\section{AFRICAN CAMP FIRES}

managed just to avoid us. The dhow also rammed the mudbank.

A dozen reluctant boys hopped overboard and pushed us off again. We pursued our merry way again. On either hand now appeared fish weirs of plaited coco fibre; which, being planted in the shallows, helped us materially to guess at the channel. Naked men, up to their shoulders in the water, attended to some mysterious need of the nets, or emerged dripping and sparkling with baskets of fish atop their heads. The channel grew even narrower, and the mudbanks more frequent. We dodged a dozen in our headlong course. Our local guide, a Swahili in tarboosh and a beautiful saffron robe, showed signs of strong excitement. We were to stop, he said, around the next bend; and at this rate we never could stop. The Yankee remarked, superfluously, that it would be handy if this dod-blistered engine had a clutch; adding as an afterthought, that no matter how long he stayed in the tropics his nose peeled. We asked what we should do if we over-carried our prospective landing place. He replied that the dod-blistered thing did have a reverse. While thus conversing we shot around a corner into a complete cul-de-sac! Everything was shut off hastily, and an instant later we and the dhow smashed up high and dry on a cozy 


\section{A TROPICAL JUNGLE}

mud beach! We drew a deep breath and looked around us.

Mangrove thicket to the edge of the slimy ooze; trees behind - that was all we could see. We gave our attention to the business of getting our men, our effects, and ourselves ashore. The ooze proved to be just above knee deep. The porters had a fearful and floundering time, and received much obvious comment from us perched in the bow of the launch. Finally everything was debarked. F. and I took off our boots; but our gunbearers expressed such horror at the mere thought of our plunging into the mud, that we dutifully climbed them pick-a-back and were carried. The hard shell beach was a hundred feet away, occupying a little recess where the persistent tough mangroves drew back. From it led a narrow path through the thicket. We waved and shouted a farewell to the crews of the launch and the dhow.

The path for a hundred feet was walled in by the mangroves through which scuttled and rattled the big land crabs. Then suddenly we found ourselves in a story-book, tropical, paradise. The tall coco palms rose tufted above everything; the fans of the younger palms waved below; bananas thrust the banners of their broad leaves wherever they could find space; creepers and vines flung the lush luxuriance of their greenery over all the earth and into 


\section{AFRICAN CAMP FIRES}

the depths of all the half-guessed shadows. In no direction could one see unobstructed farther than twenty feet, except straight up; and there one could see just as far as the tops of the palms. It was like being in a room; a green, hot, steamy, lovely room. Very bright-coloured birds that ought really to have been at home in their cages fluttered about.

We had much vigorous clearing to do to make room for our tents. By the time the job was finished we were all pretty hot. Several of the boys made vain attempts to climb for nuts; but without success. We had brought them with us from the interior where coconuts do not grow; and they did not understand the method. They could swarm up the tall slim stems all right; but could not manage to get through the downward-pointing spikes of the dead leaves. F. tried and failed, to the great amusement of the men; but to the greater amusement of myself. I was a wise person, and lay on my back on a canvas cot, so it was not much bother to look up, and enjoyed life. Not to earn absolutely the stigma of laziness, I tried to shoot some nuts down. This did not work either, for the soft, spongy stems closed around the bullet holes. Then a little wizened monkey of a Swahili porter, having watched our futile performances with interest, nonchalantly swarmed up; in some mysterious manner wriggled 


\section{A TROPICAL JUNGLE}

through the defences; and perched in the top whence he dropped to us a dozen big green nuts. Our men may not have been much of a success at climbing for nuts; but they were passed masters at the art of opening them. Three or four clips from their awkward swordlike pangas, and we were each presented with a clean, beautiful, natural goblet brimming full of a refreshing drink.

About this time a fine figure of a man drifted into camp. He was very smooth-skinned, very dignified, very venerable. He was pure Swahili, though of the savage branch of that race, and had none of the negro type of countenance. In fact so like was he in face, hair, short square beard and genial dignity to a certain great-uncle of mine that it was very hard to remember that he had on only a small strip of cloth, that he was cherishing as a great treasure a piece of soap box he had salvaged from the shore, and that his skin was red chocolate. I felt inclined to talk to him as to an intellectual equal, especially as he had a fine resonant bass voice that in itself lent his remarks some importance. However, I gave him two ordinary wood screws, showed him how they screwed in and out, and left him happy.

After supper the moon rose, casting shadows of new and unknown shapes through this strangely new and unknown forest. A thin white mist ascending 


\section{AFRICAN CAMP FIRES}

everywhere from the soil tempered but could not obscure the white brilliance. The thermometer stood now only 82 ; but the dripping tropical sweatbath in which our camp was pitched considerably raised the sensible heat. A bird with a most diabolical shrieking note cursed in the shadows. Another, a pigeonlike creature, began softly, and continued to repeat in diminishing energy until it seemed to have run down, like a piece of clockwork.

Our way next morning led for some time through this lovely but damp jungle. Then we angled up the side of a hill to emerge into the comparatively open country atop what we Westerners would call a "hog's back" - a long, narrow spurlike ridge mounting slowly to the general elevation of the main hills. Here were high green bushes, with little free open passages between them; and occasionally meadowlike openings running down the slopes on one side or the other. Before us, some miles distant, were the rounded blue hills.

We climbed steadily. It was still very early morning; but already the day was hot. Pretty soon we saw over the jungle to the gleaming waters of the inlet; and then to the sea. Our "hog's back" led us past a ridge of the hills, and before we knew it we had been deposited in a shallow valley three or four miles between parallel ridges; the said valley 


\section{A TROPICAL JUNGLE}

being at a considerable elevation, and itself diversified with rolling hills, ravines, meadow land, and wide flats. On many of the ridges were scattered coco palms; and occasional mango groves; while many smokes attested the presence of natives.

These we found in shambas or groups of little farms, huddled all together, with wilderness and brush and trees or the wide-open green grass lawn between. The houses were very large and neat looking. They were constructed quite ingeniously from coco branches. Each branch made one mat. The leaves were all brought over to the same side of the stem, and then plaited. The resulting mat was then six or seven feet long by twelve to sixteen inches broad, and could be used for a variety of purposes. Indeed we found Melville's chapter in "Typhee" as to the various uses of the coconut palm by no means exaggerated. The nuts, leaves, and fibre supplied every conceivable human want.

The natives were a pleasant, friendly, good-looking lot. In fact so like was their cast of countenance to that of the white-skinned people we were accustomed to seeing that we had great difficulty in realizing that they were mere savages, costume or lack of it - to the contrary notwithstanding. Under a huge mango tree two were engaged in dividing a sheep. Sixty or seventy others stood 


\section{AFRICAN CAMP FIRES}

solemnly around watching. It may have been a religious ceremony, for all I know; but the affair looked to be about two parts business to sixty of idle and cheerful curiosity. We stopped and talked to them a little, chaffed the pretty girls - they were really pretty - and marched on.

About noon our elegant guide stopped, struck an attitude, and pointed with his silver-headed rattan cane.

"This," said he, "is where we must camp."

We marched through a little village. A family party sat beneath the veranda of a fine building; a very old wrinkled couple; two stalwart beautiful youths; a young mother suckling her baby; two young girls; and eight or ten miscellaneous and naked youngsters. As the rest of the village appeared to be empty, I imagined this to be the caretaker's family, and the youngsters to belong to others. We stopped and spoke, were answered cheerfully, suggested that we might like to buy chickens, and offered a price. Instantly with a whoop of joy the lot of them were afoot. The fowl waited for no further intimations of troublous times, but fled squawking. They had been there before. So had our hosts; for inside a minute they had returned, each with a chicken - and a broad grin.

After due payment we proceeded on a few hundred 


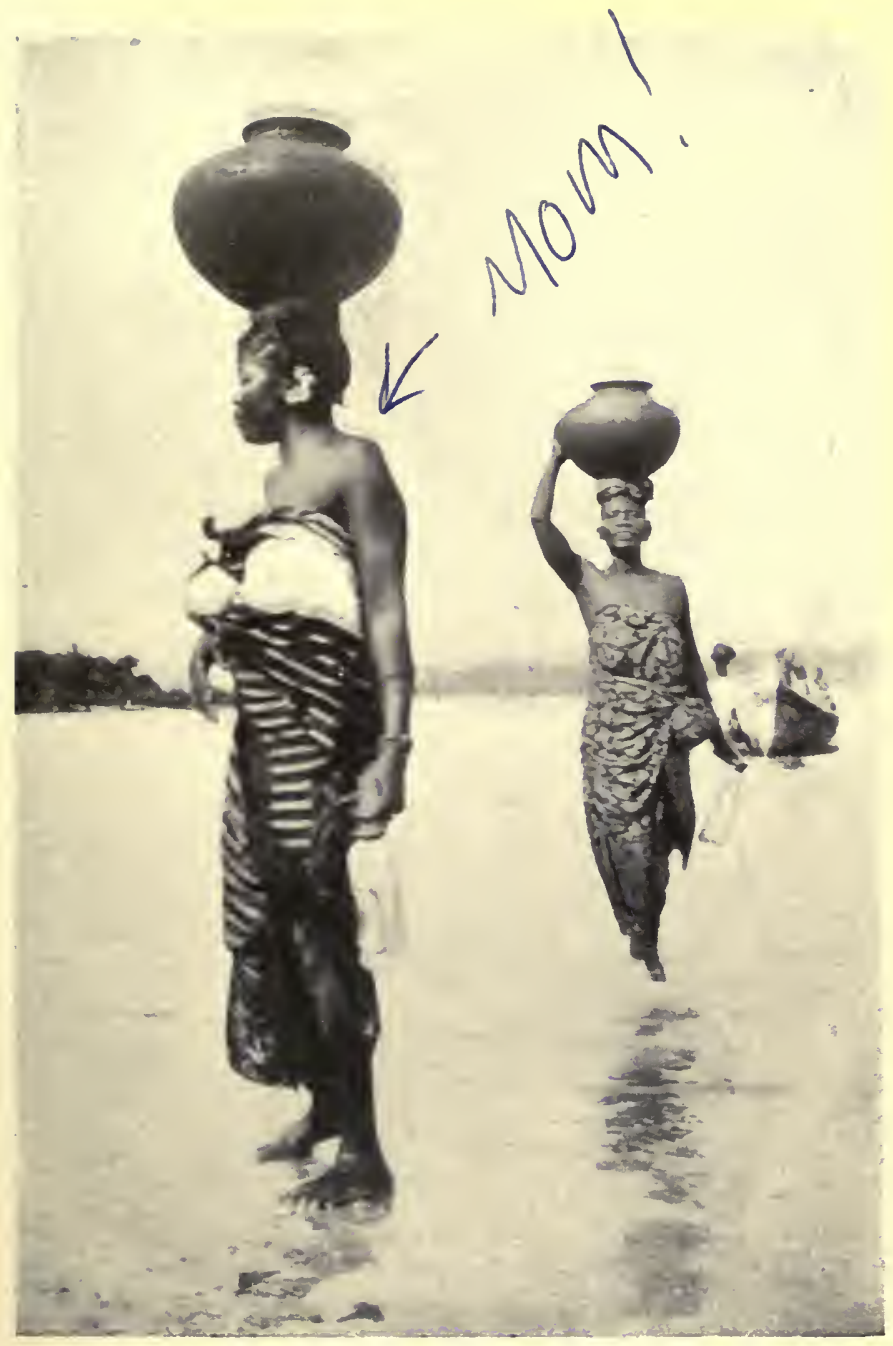

Swahili women at Mombasa 


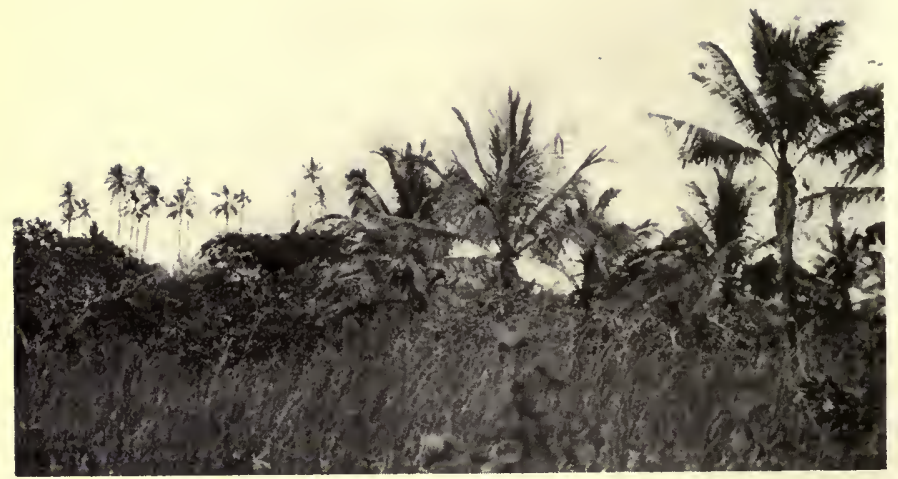

The slope fell gently away through a coconut grove

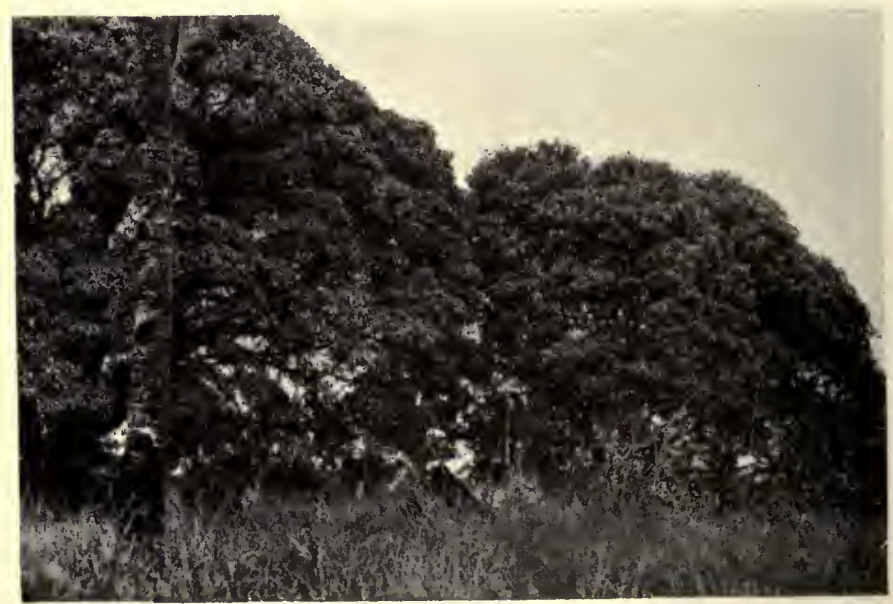

The camp beneath the mangoes 


\section{A TROPICAL JUNGLE}

yards and pitched camp beneath two huge mango trees.

Besides furnishing one of the most delicious of the tropical fruits, the mango is also one of the most beautiful of trees. It is tall, spreads very wide, and its branches sweep to within ten feet of the ground. Its perfect symmetry combined with the size and deep green of its leaves causes it to resemble, from a short distance, a beautiful green hill. Beneath its umbrella one finds dense shade, unmottled by a single ray of sunlight, so that one can lie beneath it in full confidence. For, parenthetically, even a single ray of this tropical sunlight is to the unprotected a very dangerous thing. But the leaves of the mango have this peculiarity, which distinguishes it from all other trees - namely that they grow only at the very ends of the small twigs and branches. As these, of course, grow only at the ends of the big limbs, it follows that from beneath the mango looks like a lofty green dome, a veritable pantheon of the forest.

We made our camp under one of these trees; gave ourselves all the space we could use; and had plenty left over - five tents and a cook camp, with no crowding. It was one of the pleasantest camps I ever saw. Our green dome overhead protected us absolutely from the sun; high sweet grass grew all 


\section{AFRICAN CAMP FIRES}

about us; the breeze wandered lazily up from the distant Indian Ocean. Directly before our tent door the slope fell gently away through a sparse coconut grove whose straight stems panelled our view, then rose again to the clear-cut outline of a straight ridge opposite. The crest of this was sentinelled by tall scattered coconut trees, the "bursting star" pyrotechnic effect of their tops particularly fine against the sky.

After a five hours' tropical march uphill we were glad to sit under our green dome, to look at our view, to enjoy the little breeze, and to drink some of the coconuts our friends the villagers brought in. 


\section{$\mathrm{X}$ \\ THE SABLE}

$A^{\text {BOUT three o'clock I began to feel rested and }}$ 1 ambitious. Therefore I called up our elegant guide and Memba Sasa, and set out on my first hunt for sable. F. was rather more done up by the hard morning, and so did not go along. The guide wore still his red tarboosh, his dark short jacket, his saffron yellow nether garment - it was not exactly a skirt and his silver-headed rattan cane. The only change he made was to tuck up the skirt, leaving his long legs bare. It hardly seemed altogether a suitable costume for hunting; but he seemed to know what he was about.

We snooped along ridges, and down into ravines, and across gulleys choked with brush. Horrible thickets alternated and occasionally surrounded open green meadows hanging against the sidehills. As we proceeded the country became rougher, the ravines more precipitous. We struggled up steep hills, fairly bucking our way through low growth that proved all but impenetrable. The idea was to 


\section{AFRICAN CAMP FIRES}

find a sable feeding in one of the little open glades; but whenever I allowed myself to think of the many adverse elements of the game, the chances seemed very slim. It took a half hour to get from one glade to the next; there were thousands of glades; the sable is a rare shy animal that likes dense cover fully as well if not better than the open. Sheer rank bull luck alone seemed the only hope. And as I felt my strength going in that cruel struggle against heavy brush and steep hills, I began to have very strong doubts indeed as to that sable.

For it was cruel, hard work. In this climate one hailed a car or a rickshaw to do an errand two blocks away, and considered himself quite a hero if he took a leisurely two-mile stroll along the cliff heads at sunset. Here I was, after a five-hour uphill march, bucking into brush and through country that would be considered difficult going even in Canada. At the end of twenty minutes my every garment was not wringing, but dripping, wet so that when I carried my rifle over my arm, water ran down the barrel and off the muzzle in a steady stream. After a bit of this my knees began to weaken; and it became a question of saving energy, of getting along somehow, and of leaving the actual hunting to Memba Sasa and the guide. If they had shown me a sable, I very much doubt if I could have hit it. 


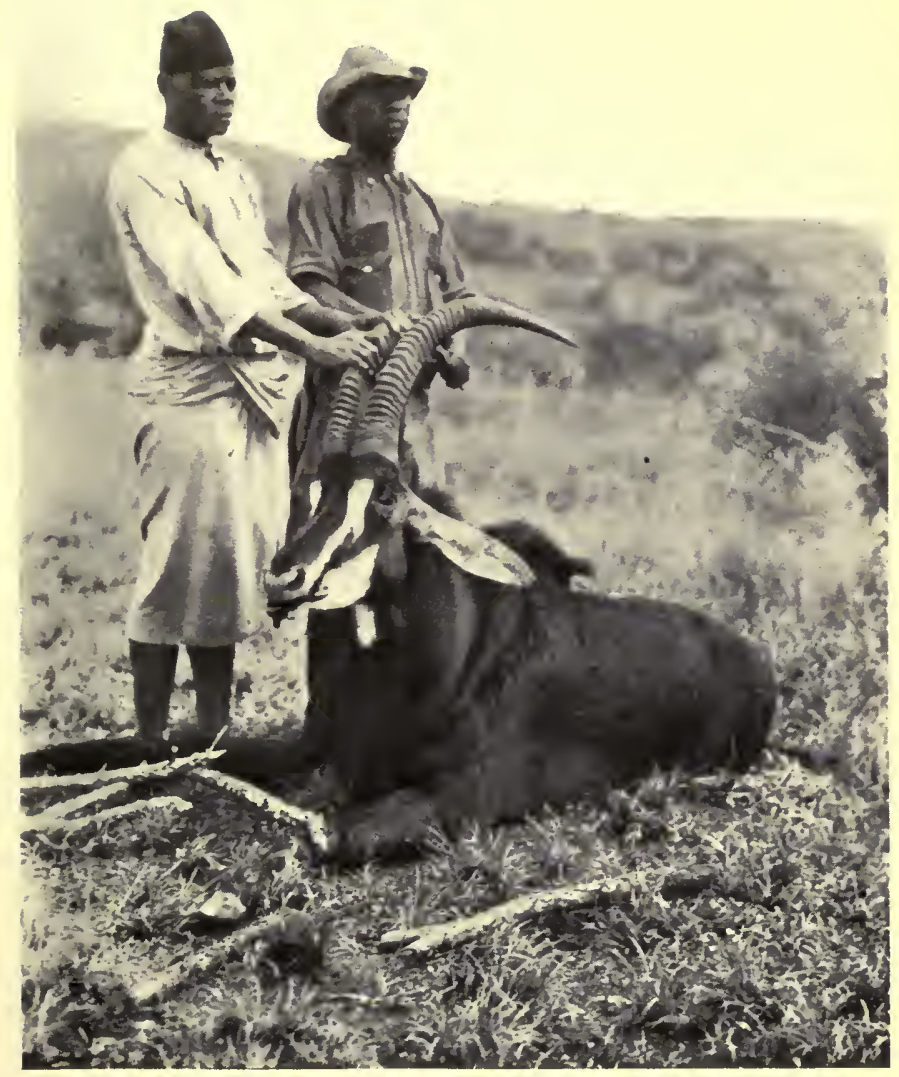

The Sable 


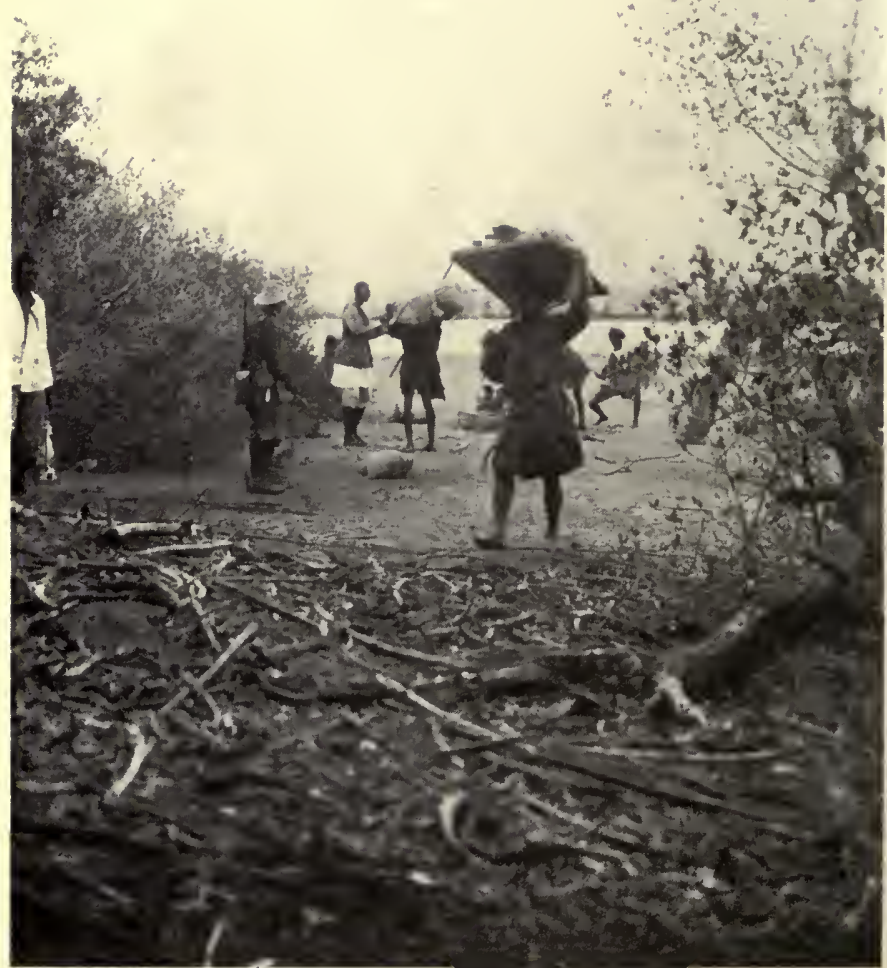

"From it led a narrow path through the thicket' 


\section{THE SABLE}

However, we did not see one; and I staggered into camp at dusk pretty well exhausted. From the most grateful hot bath and clean clothes I derived much refreshment. Shortly I was sitting in my canvas chair, sipping a coconut, and describing the condition of affairs to $\mathrm{F}$., who was naturally very curious as to how the trick was done.

"Now," I concluded, "I know just about what I can and what I cannot do. Three days more of this sort of work will feed me up plenty. If we do not run across a sable in that time, I'm afraid we don't get any."

"Two days will do for me," said he.

We called up the guide and questioned him closely. He seemed quite confident; and asserted that in this country sable were found - when they were found at all, which was not often. They must be discovered in the small grassy openings. We began to understand why so very few people get sable.

We dismissed the guide, and sat quietly smoking in the warm soft evening. The air was absolutely still save for various night insects and birds, and the weird calling of natives across the valleys. Far out toward the sea a thunderstorm flashed; and after a long interval the rumblings came to us. So very distant was it that we paid it little attention, save as an interesting background to our own still 


\section{AFRICAN CAMP FIRES}

evening. Fairly between sentences of our slow conversation, however, it rushed up to the zenith, blotting out the stars. The tall palms began to sway and rustle in the forerunning breeze. Then with a swoop it was upon us, a tempest of fury. We turned in; and all night long the heavy deluges of rain fell, roaring like surf on an unfriendly coast.

By morning this had fallen to a light steady drizzle in which we started off quite happily. In this climate one likes to get wet. The ground was sodden and deep with muck. Within a mile of camp we saw many fresh buffalo tracks.

This time we went downhill, and still downhill through openings among patches of great forest trees. The new leaves were just coming out in pinks and russets, so that the effect at a little distance was almost precisely that of our autumn foliage in the duller phases. So familiar thus were made some of the low rounded knolls that for an instant we were respectively back in the hills of Surrey or Michigan — and told each other so.

Thus we moved slowly out from the dense cover to the grass openings. Far over on another ridge F. called my attention to something jet-black and indeterminate. In another country I should have named it as a charred log on an old pine burning; for that was precisely what it looked like. We 


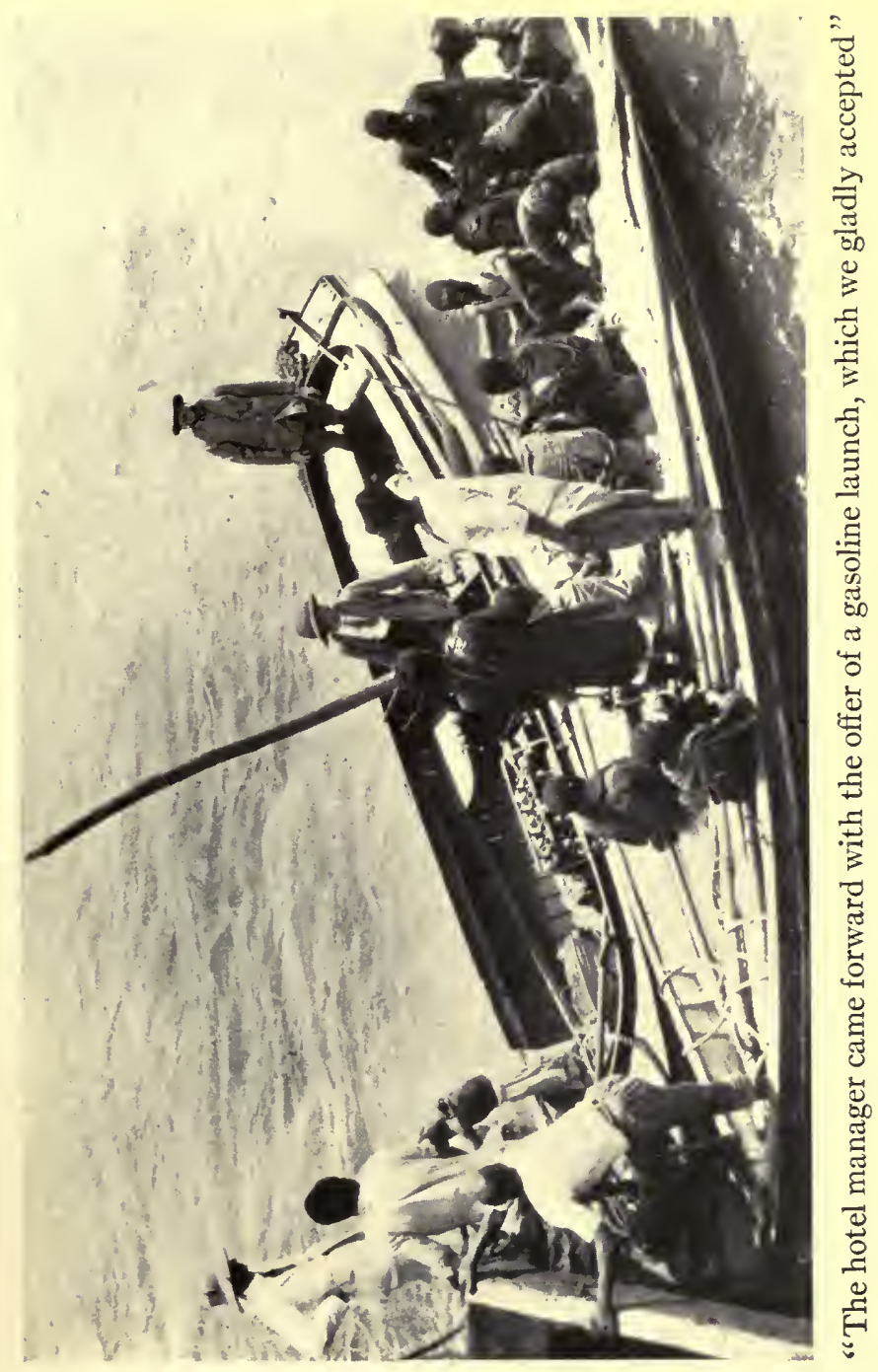




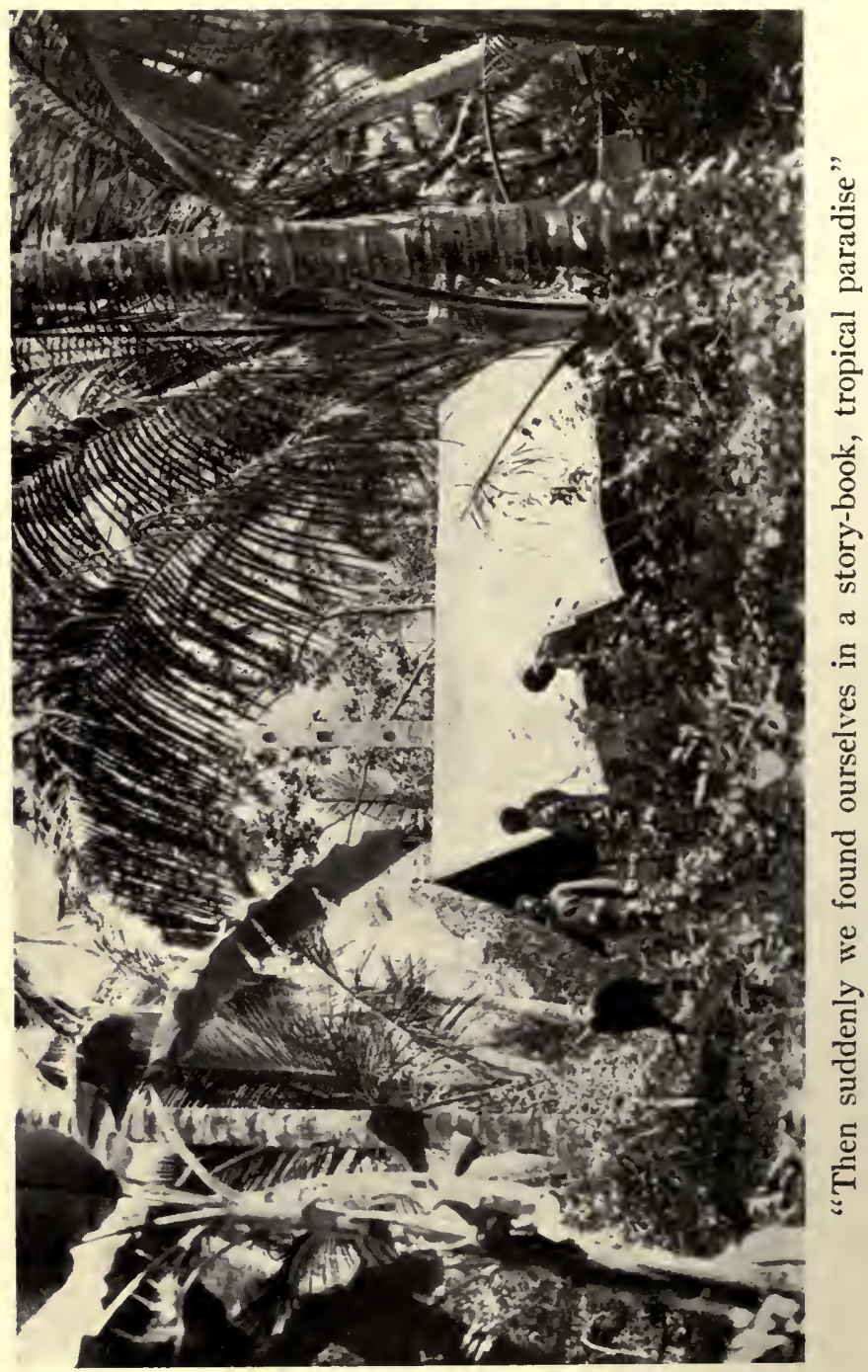




\section{THE SABLE}

glanced at it casually through our glasses. It was a sable buck lying down right out in the open. He was black and sleek, and we could make out his sweeping scimitar horns.

Memba Sasa and the Swahili dropped flat on their faces while F. and I crawled slowly and cautiously through the mud until we had gained the cover of a shallow ravine that ran in the beast's general direction. Noting carefully a certain small thicket as landmark, we stooped and moved as fast as we could down to that point of vantage. There we cautiously parted the grasses and looked. The sable had disappeared. The place where he had been lying was plainly to be identified; and there was no cover save a tiny bush between two and three feet high. We were quite certain he had neither seen nor winded us. Either he had risen and gone forward into the ravine up which we had made our stalk, or else he had entered the small thicket. F. agreed to stay on watch where he was while I slipped back and examined the earth to leeward of the thicket.

I had hardly crawled ten yards, however, before the gentle snapping of F.'s fingers recalled me to his side.

"He's behind that bush," he whispered in my ear.

I looked. The bush was hardly big enough to conceal a setter dog; and the sable is somewhat 


\section{AFRICAN CAMP FIRES}

larger than our elk. Nevertheless F. insisted that the animal was standing behind it, and that he had caught the toss of its head. We lay still for some time, while the soft, warm rain drizzled down on us, our eyes riveted on the bush. And then - we caught the momentary flash of curved horns as the sable tossed his head. It seemed incredible even then that the tiny bush should conceal so large a beast. As a matter of fact we later found that the bush grew on a slight elevation behind which was a depression. In this the sable stood, patiently enduring the drizzle.

We waited some time in hopes he would move forward a foot or so; but apparently he had selected his loafing place with care, and liked it. The danger of a shift of wind was always present. Finally I slipped back over the brink of the ravine, moved three yards to the left, and crawled up through the tall dripping grass to a new position behind a little bush. Cautiously raising my head I found I could see plainly the sable's head and part of his shoulders. My position was cramped and out of balance for offhand shooting; but I did my best, and heard the loud plunk of the hit. The sable made off at a fast though rather awkward gallop, wheeled for an instant a hundred yards farther on, received another bullet in the shoulder, and disappeared over the 


\section{THE SABLE}

brow of the hill. We raced over the top to get in another shot, and found him stone dead.

He was a fine beast, jet-black in coat with white markings on the face, red-brown ears, and horns sweeping up and back scimitar fashion. He stood four feet and six inches at the shoulder, and his horns were second best ever shot in British East Africa. This beast has been described by Heller as a new subspecies, and named Rooseveltii. His determination was based upon an immature buck and a doe shot by Kermit Roosevelt. The determination of subspecies on so slight evidence seems to me unscientific in the extreme. While the immature males do exhibit the general brown tone mainly relied on by Mr. Heller, the mature buck differs in no essential from the type sable. I find the alleged subspecies is not accepted by European scientists. 


\section{XI}

\section{A MARCH ALONG THE COAST}

T HAD now a most comfortable feeling that my I task was done, that suddenly the threatening clouds of killing work had been cleared up, and that now I was privileged to loaf and invite my soul on this tropical green hilltop while poor F. put in the days trying to find another sable. Every morning he started out before daylight. I could see the light of his lantern outside the tent; and I stretched myself in the luxurious consciousness that I should hear no deprecating but insistent "hodie" from my boy until I pleased to invite it. In the afternoon or evening F. would return, quite exhausted and dripping, with only the report of new country traversed. No sable; no tracks of sable; no old signs, even, of sable. Gradually it was borne in on me how lucky I was to have come upon my magnificent specimen so promptly and in such favourable circumstances.

A leisurely breakfast alone, with the sun climbing; then the writing of notes, a little reading, and perhaps a stroll to the village or along the top of the 96 


\section{A MARCH ALONG THE COAST}

ridge. At the heat of noon a siesta, with a cool coconut at my elbow. The view was beautiful on all sides; our great tree full of birds; the rising and dying winds in the palms like the gathering oncoming rush of the rains. From mountain to mountain sounded the wild, far-carrying ululations of the natives, conveying news or messages across the wide jungle. Toward sunset I wandered out in the groves, enjoying the many bright flowers, the tall, sweet grasses, and the coco palms against the sky. Piles of coconuts lay on the ground, covered each with a leaf plaited in a peculiarly individual manner to indicate ownership. Small boys, like little black imps, clung naked halfway up the slim trunks of the palms, watching me bright-eyed above the undergrowth. In all directions, crossing and recrossing, ran a maze of beaten paths. Each led somewhere, but it would require the memory of well, of a native, to keep all their destinations in mind.

I used to follow some of them to their ending in little coco-leaf houses on the tops of knolls or beneath mangoes; and would talk with the people. They were very grave and very polite; and seemed to be living out their lives quite correctly according to their conceptions. Again, it was borne in on me that these people are not stumbling along the course 


\section{AFRICAN CAMP FIRES}

of evolution in our footsteps, but have gone as far in their path as we have in ours; that they have reached at least as complete a correspondence with their environment as we with our own.*

If $\mathrm{F}$. had not returned by the time I reached camp, I would seat myself in my canvas chair, and thence dispense justice, advice, or medical treatment. If none of these things seemed demanded, I smoked my pipe. To me one afternoon came a big-framed, old, dignified man, with the heavy beard, the really noble features, the high forehead and the blank statue eyes of the blind Homer. He was led by a very small, very bright-eyed naked boy. At some twenty feet distance he squatted down cross-legged before me. For quite five minutes he sat there silent, while I held down my camp chair, smoked and waited. At last he spoke in a rolling deep bass voice rich and vibrating - a delight to hear.

"Jambo (greeting)!" said he.

"Jambo!" I replied mildly.

Again a five-minute silence. I had begun reading, and had all but forgotten his presence.

"Jambo bwana (greeting, master)!" he rolled out. "Jambo!" I repeated.

The same dignified, unhasting pause.

"Jambo bwana m'kubwa (greeting great master)!"

"For a fuller discussion see "The Land of Footprints." 


\section{A MARCH ALONG THE COAST}

"Jambo!" quoth $\mathrm{I}$, and went on reading. The sun was dropping, but the old man seemed in no hurry.

"Jambo bwana m'kubwa sana (greeting most mighty master)!" he boomed at last.

"Jambo!" said I.

This would seem to strike the superlative, and I expected now that he would state his business, but the old man had one more shot in his locker.

"Jambo bwana m'kubwa kabeesa sana (greeting mightiest possible master)!" it came.

Then in due course he delicately hinted that a gift of tobacco would not come amiss.

F. returned a trifle earlier than usual to admit that his quest was hopeless, that his physical forces were, for the time being, at an end, and that he was willing to go out.

Accordingly very early next morning we set out by the glimmer of a lantern, hoping to get a good start on our journey before the heat of the day became too severe. We did gain something, but performed several unnecessary loops and semicircles in the maze of beaten paths before we finally struck into one that led down the slope toward the sea. Shortly after the dawn came up "like thunder" in its swiftness, followed almost immediately by the sun. 


\section{AFRICAN CAMP FIRES}

Our way now led along the wide flat between the seashore and the Shimba Hills in which we had been hunting. A road ten feet wide and innocent of wheels ran with obstinate directness up and down the slight contours and through the bushes and coconut groves that lay in its path. So mathematically straight was it that only when perspective closed it in, or when it dropped over the summit of a little rise, did the eye lose the effect of its interminability. The country through which this road led was various - open bushy veldt with sparse trees, dense jungle, coconut groves, tall and cool. In the shadows of the latter were the thatched native villages. To the left always ran the blue Shimba Hills; and far away to the right somewhere we heard the grumbling of the sea.

Every hundred yards or so we met somebody. Even this early the road was thronged. By far the majority were the almost naked natives of the district, pleasant, brown-skinned people with good features. They carried things. These things varied from great loads balanced atop to dainty impromptu baskets woven of coco-leaves and containing each a single coconut. They smiled on us, returned our greeting, and stood completely aside to let us pass. Other wayfarers were of more importance. Small groups of bearded dignitaries, either upper-class 


\section{A MARCH ALONG THE COAST}

Swahili or pure Arabs, strolled slowly along, apparently with limitless leisure, but evidently bound somewhere, nevertheless. They replied to our greetings with great dignity. Once, also, we overtook a small detachment of Soudanese troops moving. They were scattered over several miles of road. A soldier, most impressive and neat in khaki and red tarboosh and sash; then two or three of his laughing, sleek women, clad in the thin, patterned "Mericani," glittering with gold ornaments; then a half dozen ragged porters carrying official but battered, painted wooden kit boxes, or bags, or miscellaneous curious plunder; then more troopers; and so on for miles. They all drew aside for us most respectfully; and the soldiers saluted, very smart and military.

Under the broad-spreading mangoes near the villages we came upon many open markets in full swing. Each vendor squatted on his heels behind his wares, while the purchasers or traders wandered here and there making offers. The actual commerce compared with the amount of laughing, joking, shrieking joy of the occasion as one to a thousand.

Generally three or four degenerate looking dirty East Indians slunk about, very crafty, very insinuating, very ready and skillful to take what advantages they could. I felt a strong desire to kick every one 


\section{AFRICAN CAMP FIRES}

of them out from these joyful concourses of happy people. Generally we sat down for a while in these markets, and talked to the people a little, and perhaps purchased some of the delicious fruit. They had a small delicate variety of banana, most wonderful, the like of which I have seen nowhere else. We bought forty of these for a coin worth about eight cents. Besides fruit, they offered coconuts in all forms, grain, woven baskets, small articles of handicraft - and fish. The latter were farther from the sea than they should have been! These occasional halts greatly refreshed us for more of that endless road.

For all this time we were very hot. As the sun mounted, the country fairly steamed. From the end of my rifle barrel, which I carried across my forearm, a steady trickle of water dripped into the road. We neither of us had a dry stitch on us; and our light garments clung to us thoroughly wet through. At first we tried the military method, and marched fifty minutes to rest ten; but soon discovered that twenty-five minutes' work to five minutes off was more practical. The sheer weight of the sun was terrific; after we had been exposed to it for any great length of time - as across several wide open spaces - we entered the steaming shade of the jungle with gratitude. At the end of seven hours, 


\section{A MARCH ALONG THE COAST}

however, we most unexpectedly came through a dense coconut grove plump on the banks of the harbour at Kilindini.

Here, after making arrangements for the transport of our safari, when it should arrive, we entrusted ourselves to a small boy and a cranky boat. An hour later, clad in tropical white, with cool drinks at our elbows, we sat in easy chairs on the veranda of the Mombasa Club.

The clubhouse is built on a low cliff at the water's edge. It looks across the blue waters of the bay to a headland crowned with coco palms; and beyond the headland to the Indian Ocean. The cool trades sweep across that veranda. We idly watched a lone white oarsman pulling strongly against the wind through the tide rips, evidently bent on exercise. We speculated on the incredible folly of wanting exercise; and forgot him. An hour later a huge saffron yellow squall rose from China 'cross the way, filled the world with an unholy light, lashed the reluctant sea to whitecaps, and swooped screaming on the coco palms. Police boats to rescue the idiot oarsman! Much minor excitement! Great rushing to and fro! We continued to sit in our lounging chairs, one hand on our cool long drinks. 


\section{XII \\ THE FIRE}

WE WERE very tired, so we turned in early. Unfortunately our rooms were immediately over the billiard room where a bibulous and cosmopolitan lot were earnestly endeavouring to bolster up by further proof the fiction that a white man cannot retain his health in the tropics. The process was pretty rackety, and while it could not keep us awake, it prevented us from falling thoroughly asleep. At length, and suddenly, the props of noise fell away from me, and I sank into a grateful, profound abyss.

Almost at once, however, I was dragged back to consciousness. Mohamet stood at my bedside.

"Bwana," he proffered to my rather angry inquiry, "all the people have gone to the fire. It is a very large fire. I thought you would like to see it."

I glanced out of the window at the reddening sky, thrust my feet into a pair of slippers and went forth in my pajamas to see what I could see.

We threaded our way through many narrow dark 


\section{THE FIRE}

and deserted streets, beneath balconies that overhung, past walls over which nodded tufted palms, until a loud and increasing murmuring told us we were nearing the centre of disturbance. Shortly we came to the outskirts of the excited crowd, and beyond them saw the red furnace glow.

"Seméelay! Seméelay!" warned Mohamet authoritatively; and the bystanders, seeing a white face, gave me passage.

All of picturesque Mombasa was afoot - Arabs, Swahilis, Somalis, savages, Indians - the whole lot. They moved restlessly in the narrow streets; they hung over the edges of balconies; they peered from barred windows; interested dark faces turned up everywhere in the flickering light. One woman, a fine, erect biblical figure, stood silhouetted on a flat housetop and screamed steadily. I thought she must have at least one baby in the fire, but it seems she was only excited.

The fire was at present confined to two buildings, in which it was raging fiercely. Its spread, however, seemed certain; and, as it was surrounded by warehouses of valuable goods, moving was in full swing. A frantic white man stood at the low doorway of one of these dungeonlike stores hastening the movements of an unending string of porters. As each emerged bearing a case on his shoulder, the white man urged 


\section{AFRICAN CAMP FIRES}

him to a trot. I followed up the street to see where these valuables were being taken, and what were the precautions against theft. Around the next corner, it seemed. As each excited perspiring porter trotted up, he heaved his burden from his head or his shoulders, and promptly scampered back for another load. They were loyal and zealous men; but their headpieces were deficient inside. For the burdens that they saved from the fire happened to be cases of gin in bottles. At least, it was in bottles until the process of saving had been completed. Then it trickled merrily down the gutter. I went back and told the frantic white man about it. He threw up both hands to heaven and departed.

By dodging from street to street Mohamet and I succeeded in circling the whole disturbance, and so came at length to a public square. Here was a vast throng, and a very good place, so I climbed atop a rescued bale of cotton the better to see.

Mombasa has no water system, but a wonderful corps of water-carriers. These were in requisition to a man. They disappeared down through the wide gates of the customs enclosure, their naked, muscular, light-brown bodies gleaming with sweat, their Standard Oil cans dangling merrily at the ends of slender poles. A moment later they emerged, the cans full of salt water from the bay, the poles seeming 


\section{THE FIRE}

fairly to bite into their bare shoulders as they teetered along at their rapid, swaying, burdened gait.

The moment they entered the square they were seized upon from a dozen different sides. There was no system at all. Every owner of property was out for himself, and intended to get as much of the precious water as he could. The poor carriers were pulled about, jerked violently here and there, besought, commanded to bring their loads to one or the other of the threatened premises. Vociferations, accusations, commands arose to screams. One old graybeard occupied himself by standing on tiptoe and screeching, "Maji! maji! maji!" at the top of his voice, as though that added anything to the visible supply. The water-carrier of the moment disappeared in a swirl of excited contestants. He was attending strictly to business, looking neither to right nor to left, pushing forward as steadily as he could, gasping mechanically his customary warning: "Seméelay! Seméelay!" Somehow, eventually, he and his comrades must have got somewhere; for after an interval he returned with empty buckets. Then every blessed fool of a property owner took a whack at his bare shoulders as he passed, shrieking hysterically, "Haya! haya! pesi! pesi!" and the like to men already doing their best. It was a grand sight! 


\section{AFRICAN CAMP FIRES}

In the meantime the fire itself was roaring away. The old graybeard suddenly ceased crying maji, and darted forward to where I stood on the bale of cotton. With great but somewhat flurried respect he begged me to descend. I did so, somewhat curious as to what he might be up to, for the cotton was at least two hundred feet from the fire. Immediately he began to tug and heave; the bale was almost beyond his strength; but after incredible exertions he lifted one side of it, poised it for a moment, got his shoulder under it, and rolled it over once. Then he darted away and resumed his raucous crying for water. I climbed back again. Thrice more, at intervals, he repeated this performance. The only result was to daub with mud every possible side of that bale. I hope it was his property.

You must remember that I was observing the heavy artillery of the attack on the conflagration. Individual campaigns were everywhere in progress. I saw one man standing on the roof of a threatened building. He lowered slowly, hand over hand, a small tea kettle at the end of a string. This was filled by a friend in the street, whereupon the man hauled it up again, slowly, hand over hand, and solemnly dashed its contents into the mouth of the furnace. Thousands of other men on roofs, in 


\section{THE FIRE}

balconies, on the street, were doing the same thing. Some had ordinary cups which they filled a block away! The limit of efficiency was a pail. Nobody did anything in concert with anybody else. The sight of these thousands of little midgets, each with his teacup, or his teapot, or his tin pail, throwing each his mite of water - for which he had to walk a block or so - into the ravening roaring furnace of flame was a sight as pathetic or as comical as you please. They did not seem to have a show in the world.

Nevertheless, to my vast surprise, the old system of the East won out at last. The system of the East is that if you get enough labour you can accomplish anything. Little by little those thousands of teakettles of water had their aggregate effect. The flames fed themselves out and died down leaving the contiguous buildings unharmed save for a little scorching. In two hours all was safe, and I returned to the hotel, having enjoyed myself hugely. I had, however, in the interest and excitement, forgotten how deadly is the fever of Mombasa. Midnight in pajamas did the business; and shortly I paid well for the fun. 


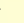




\section{PART III}

NAIROBI 



\section{XIII \\ UP FROM THE COAST}

TAIROBI is situated at the far edge of the great 1 Athi Plains and just below a range of hills. It might about as well have been anywhere else; and perhaps better a few miles back in the higher country. Whether the funny little narrow guage railroad exists for Nairobi, or Nairobi for the railroad, it would be difficult to say. Between Mombasa and this interior placed-to-order town, certainly, there is nothing, absolutely nothing, either in passengers or freight, to justify building the line. That distance is if I remember it correctly about three hundred and twenty miles. A dozen or so names of stations appear on the map. These are water tanks, telegraph stations, or small groups of tents in which dwell black labourers - on the railroad.

The way climbs out from the tropical steaming coast belt to and across the high scrub desert, and then through lower rounded hills to the plains. On the desert is only dense thorn brush - and a possibility that the newcomer, if he looks very closely, 


\section{AFRICAN CAMP FIRES}

may to his excitement glimpse his first game in Africa. This is a stray duiker or so, tiny grass antelopes a foot high. Also in this land is Thirst; so that alongside the locomotives, as they struggle up grade, in bad seasons, run natives to catch precious drops.* An impalpable red dust sifts through and into everything. When one descends at Voi for dinner he finds his fellow travellers have changed complexion. The pale clerk from indoor Mombasa has put on a fine healthy sunburn; and the company in general present a rich out-of-doors bloom. A chance dab with a white napkin comes away like fresh paint, however.

You clamber back into the compartment, with its latticed sun shades and its smoked glass windows; you let down the narrow canvas bunk; you unfold your rug, and settle yourself for repose. It is a difficult matter. Everything you touch is gritty. The air is close and stifling, like the smoke-charged air of a tunnel. If you try to open a window you are suffocated with more of the red dust. At last you fall into a doze; to awaken nearly frozen! The train has climbed into what is, after weeks of the tropics, comparative cold; and if you have not been warned to carry wraps, you are in danger of congestions.

*The Government does much nowadays by means of tank cars. 


\section{UP FROM THE COAST}

The gray dawn comes; and shortly, in the sudden tropical fashion, the full light. You look out on a wide smiling grass country, with dips and swales, and brushy river bottoms, and long slopes and hills thrusting up in masses from down below the horizon, and singly here and there in the immensities nearer at hand. The train winds and doubles on itself up the gentle slopes and across the imperceptibly rising plains. But the interest is not in these wide prospects, beautiful and smiling as they may be, but in the game. It is everywhere. Far in the distance the herds twinkle, half guessed in the shimmer of the bottom lands or dotting the sides of the hills. Nearer at hand it stares as the train rumbles and sways laboriously past. Occasionally it even becomes necessary to whistle aside some impertinent kongoni that has placed himself between the metals! The newcomer has but a theoretical knowledge at best of all these animals; and he is intensely interested in identifying the various species. The hartebeeste and the wildebeeste he learns quickly enough; and of course the zebra and the giraffe are unmistakable; but the smaller gazelles are legitimate subjects for discussion. The wonder of the extraordinary abundance of these wild animals mounts as the hours slip by. At the stops for water or for orders the passengers gather from their 


\section{AFRICAN CAMP FIRES}

different compartments to detail excitedly to each other what they have seen. There is always an honest super-enthusiast who believes he has seen rhinoceros, lions, or leopards. $\mathrm{He}$ is looked upon with envy by the credulous, and with exasperation by all others.

So the little train puffs and tugs along. Suddenly it happens on a barbed-wire fence, and immediately after enters the town of Nairobi. The game has persisted right up to that barbed wire fence.

That station platform is thronged with a heterogeneous multitude of people. The hands of a dozen raggetty black boys are stretched out for luggage. The newcomer sees with delight a savage with a tin can in his stretched ear lobe; another with a set of wooden skewers set fanwise around the edge of the ear; he catches a glimpse of a beautiful naked creature, very proud, very decorated with beads and heavy polished wire. Then he is ravished away by the friend, or agent, or hotel representative who has met him, and hurried out through the gates between the impassive and dignified Sikh sentries to the hack. I believe nobody but the newcomer ever rides in the hack; and then but once, from the station to the hotel. After that he uses rickshaws. In fact it is probable that the hack is maintained for the sole purpose of giving the newcomer a grand 


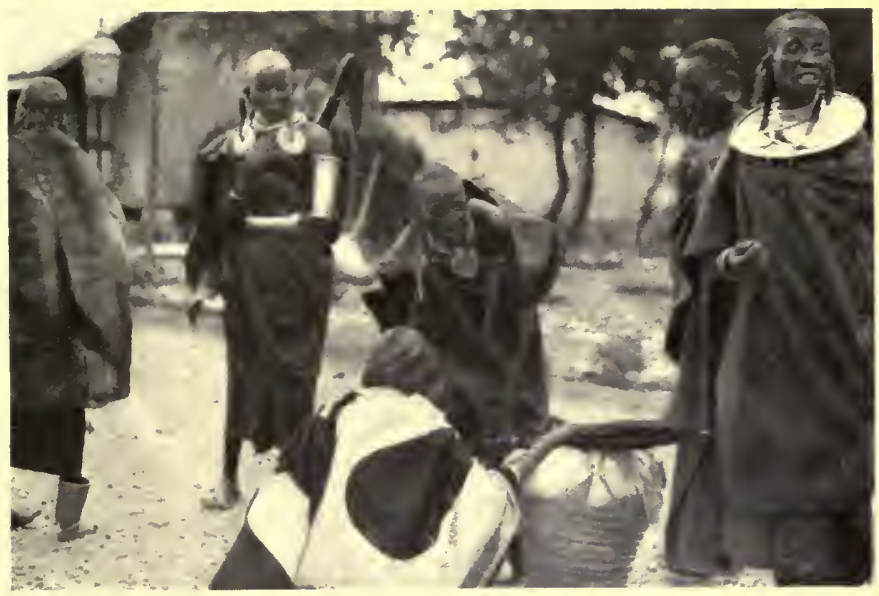

Masai women at a station of the Uganda Railroad

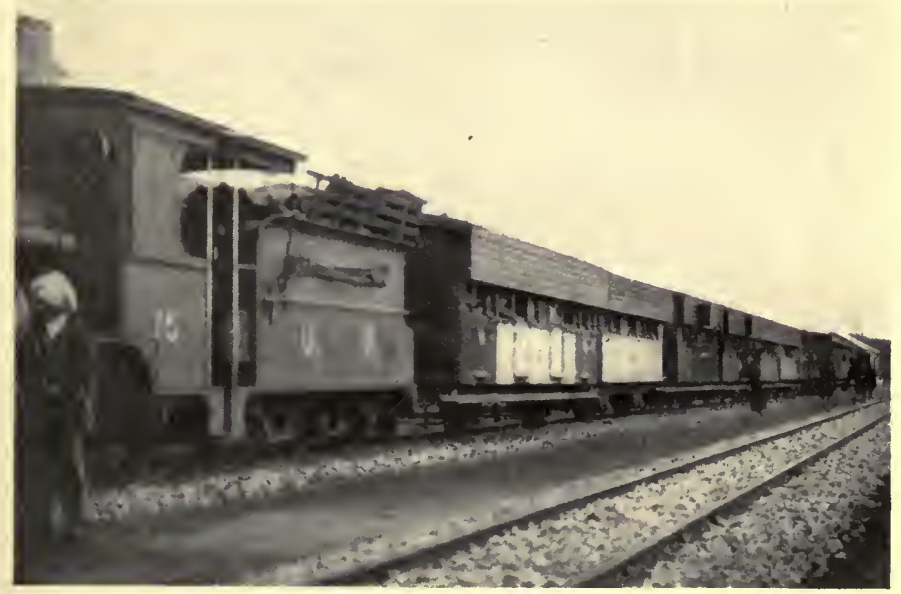

Train on the Uganda Railway 


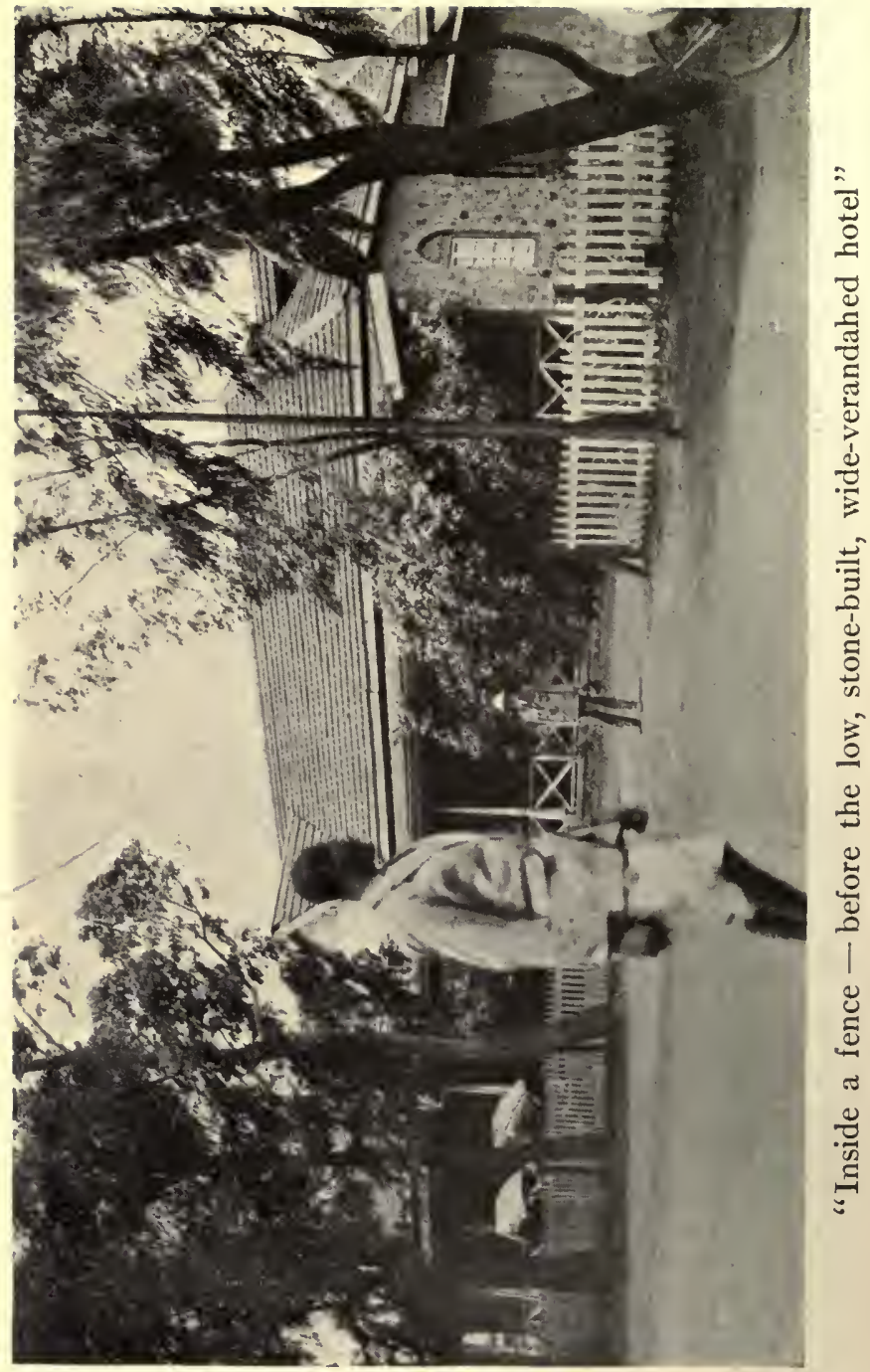




\section{UP FROM THE COAST}

and impressive entrance. This brief fleeting quarter hour of glory is unique and passes. It is like crossing the Line, or the first kiss, something that in its nature cannot be repeated.

The hack was once a noble vehicle, compounded of opulent curves, with a very high driver's box in front, a little let-down bench, and a deep luxurious shell-shaped back seat reclining in which one received the adulation of the populace. That was in its youth. Now in its age the varnish is gone; the upholstery of the back seat frayed; the upholstery of the small seat seat lacking utterly, so that one sits on bare boards. In place of two dignifiedly spirited fat white horses, it is drawn by two very small mules in a semi-detached position far ahead. And how it rattles!

Between the station and the hotel at Nairobi is a long, straight, wide, well-made street, nearly a mile long, and bordered by a double row of young eucalyptus. These latter have changed the main street of Nairobi from the sunbaked array of galvanized houses described by travellers of a half dozen years back to a thoroughfare of great charm. The iron houses and stores are now in a shaded background; and the attention is freed to concentrate on the vivid colouring, the incessant movement, the great interest of the people moving to and fro. 


\section{AFRICAN CAMP FIRES}

When I left Nairobi the authorities were considering the removal of these trees because one row of them had been planted slightly within the legal limits of the street. What they could interfere with in a practically horseless town I cannot imagine; but trust this stupidity gave way to second thought.

The hack rattles and careers up the the length of the street, scattering rickshaws and pedestrians from before its triumphant path. To the left opens a wide street of little booths under iron awnings, hung with gay colour and glittering things. The street is thronged from side to side with natives of all sorts. It whirls past; and shortly after the hack dashes inside a fence and draws up before the low stonebuilt, wide-verandaed hotel. 


\section{XIV}

\section{A FIAT TOWN}

T T HAS been, as I have said, the fashion to speak 1 of Nairobi as an ugly little town. This was probably true when the first corrugated iron houses huddled unrelieved near the railway station. It is not true now. The lower part of town is well planted and is always picturesque as long as its people are astir. The white population have built in the wooded hills some charming bungalows surrounded by bright flowers or lost amid the trunks of great trees. From the heights on which is Government House one can, with a glass, watch the game herds feeding on the plains. Two Country Clubs with the usual games of golf, polo, tennis - especially tennis football and cricket; a weekly hunt, with jackals instead of foxes; a bungalow town club on the slope of a hill; an electric light system; a race track; a rifle range; frilly parasols and the latest fluffiest summer toilettes from London and Paris - I mention a few of the refinements of civilization that offer to the traveller some of the most piquant of contrasts. 


\section{AFRICAN CAMP FIRES}

For it must not be forgotten that Nairobi, in spite of these things - due to the direct but slender thread of communication by railroad and ships is actually in the middle of an African wilderness; is a black man's town, as far as numbers go.*

The game feeds to its very outskirts, even wanders into the streets at night. $\dagger$ Lions may be heard roaring within a mile or so of town; and leopards occasionally at night come on the verandas of the outlying dwellings. Naked savages from the jungle untouched by civilization in even the minutest particular wander the streets unabashed.

It is this constantly recurring, sharply drawn contrast that gives Nairobi its piquant charm. As one sits on the broad hotel veranda a constantly varied pageant passes before him. A daintily dressed, fresh-faced Englishwoman bobs by in a smart rickshaw drawn by two uniformed runners; a Kikuyu, annointed, curled, naked, brass adorned, teeters along, an expression of satisfaction on his face; a horseman, well appointed, trots briskly by followed by his loping syce; a string of skin-clad women, their heads fantastically shaved, heavily ornamented, lean forward under the burden of firewood for the market; a beautiful baby in a frilled baby cab is

*Fifteen hundred whites to twelve thousand natives, approxirately.

†This happened twice while $I$ was in the country. 


\section{A FIAT TOWN}

propelled by a tall, solemn, fine-looking black man in white robe and cap; the driver of a high cart tools his animal past a creaking, clumsy, two-wheeled wagon drawn by a pair of small humpbacked native oxen. And so it goes, all day long, without end. The public rickshaw boys just across the way chatter and game and quarrel and keep a watchful eye out for a possible patron on whom to charge vociferously at full tilt. Two or three old-timers with white whiskers and red faces continue to slaughter thousands and thousands and thousands of lions from the depths of their easy chairs.

The stone veranda of that hotel is a very interesting place. Here gather men from all parts of East Africa, from Uganda, and the jungles of the Upper Congo. At one time or another all the famous hunters drop into its canvas chairs - Cuninghame, Allan Black, Judd, Outram, Hoey, and the others; white traders with the natives of distant lands; owners of farms experimenting bravely on a greater or lesser scale in a land whose difficulties are just beginning to be understood; great naturalists and scientists from the governments of the earth, eager to observe and collect in this interesting and teeming fauna; and sportsmen just out and full of interest or just returned and modestly important. More absorbing conversation can be listened to on this 


\section{AFRICAN CAMP FIRES}

veranda than in any other one place in the world. The gathering is cosmopolitan; it is representative of the most active of every social, political, and racial element; it has done things; it contemplates vital problems from the vantage ground of experience. The talk veers from pole to pole - and returns always to lions.

Every little while a native - a raw savage comes along and takes up a stand just outside the railing. He stands there mute and patient for five minutes - a half hour - until some one, any one, happens to notice him.

" $N$ 'jo! - come here!" commands this person.

The savage proffers a bit of paper on which is written the name of the one with whom he has business.

"Nenda officie!" indicates the charitable person waving his hand toward the hotel office. Then, and not until this permission has been given by some one, dares the savage cross the threshold to do his errand.

If the messenger happens to be a trained houseboy, however, dressed in his uniform of khaki or his more picturesque white robe and cap, he is privileged to work out his own salvation. And behind the hotel are rows and rows of other boys, each waiting patiently the pleasure of his especial brwana lounging at ease after strenuous days. At the drawling shout of "boy!" one of them instantly departs to find out which particular boy is wanted. 


\section{A FIAT TOWN}

The moment any white man walks to the edge of the veranda a half dozen of the rickshaws across the street career madly around the corners of the fence, bumping, colliding, careening dangerously, to drop beseechingly in serried confusion close around the step. The rickshaw habit is very strong in Nairobi. If a man wants to go three blocks down the street, he takes a rickshaw for that stupendous journey. There is in justification the legend that the white man should not exert himself in the tropics. I fell into the custom of the country until I reflected that it would hardly be more fatal for me to walk a half hour in the streets of Nairobi than to march six or seven hours - as I often did - when on safari or in the hunting field. After that I got a little exercise to the vast scandal of the rickshaw boys. In fact, so unusual was my performance that at first I had fairly to clear myself a way with my kiboko. After a few experiences they concluded me a particularly crazy person and let me alone.

Rickshaws, however, are very efficient and very cheap. The runners two in number, are lithe little round-headed Kavirondos, generally, their heads shaved to leave a skullcap, clad in scant ragged garments, and wearing each an anklet of little bells. Their passion for ornament they confine to small bright things in their hair and ears. They run easily, 


\section{AFRICAN CAMP FIRES}

with a very long stride. Even steep hills they struggle up somehow, zigzagging from one side of the road to the other, edging along an inch or so at a time. In such places I should infinitely have preferred to have walked, but that would have lost me caste everywhere. There are limits even to a crazy man's idiosyncrasies. For that reason I never thoroughly enjoyed rickshaws; save along the level ways with bells jingling and feet pat-patting a rapid tune. Certainly I did not enjoy them going down the steep hills. The boy between the shafts in front hits the landscape about every forty feet. I do not really object to sudden death; but this form of it seemed unfair to some poor hungry lion.

However the winding smooth roads among the forested, shaded bungalows of the upper part of town were very attractive, especially toward evening. At that time the universal sun helmet or double terai could be laid aside for straw hats, cloth caps, or bare heads. People played the more violent games, or strolled idly. At the hotel there was now a good deal of foolish drinking; foolish, because in this climate it is very bad for the human system, and in these surroundings of much interest and excitement the relief of its exaltation from monotony or ennui or routine could hardly be required. 


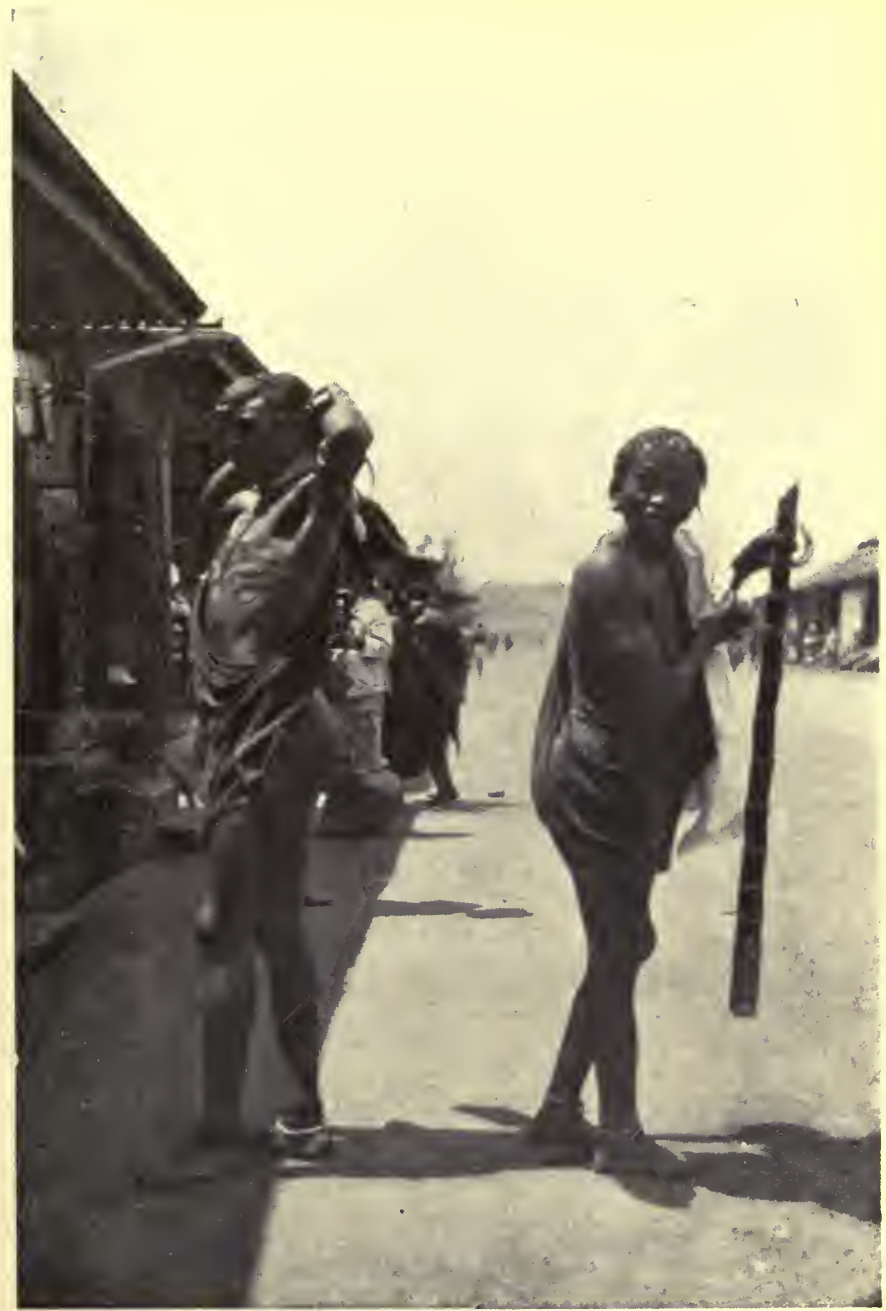

"Savages from the jungle untouched by civilization wander the streets unabashed" 


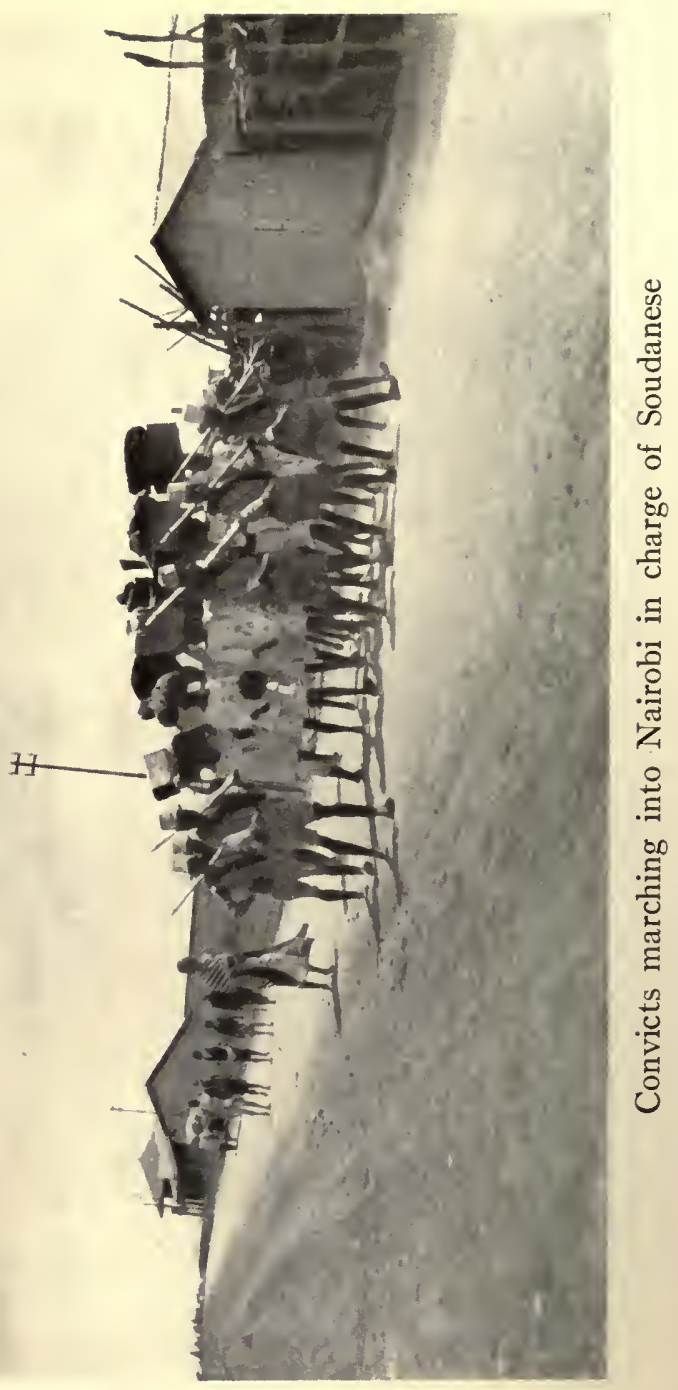




\section{XV \\ PEOPLE}

CONSIDERED as a class rather than as individuals the dark-skinned population is easily the more interesting. Considered as individuals, the converse is true. Men like Sir Percy Girouard, Hobley, Jackson, Lord Delamere, McMillan, Cuninghame, Allan Black, Leslie Tarleton, Vanderweyer, the Hill cousins, Horne, and a dozen others are nowhere else to be met in so small a community. But the whites have developed nothing in their relations one to another essentially different. The artisan and shopkeeping class well on the flats; the Government people and those of military connections live on the heights one side of the little stream; the civil-service and bigger business men among the hills on the other. Between them all is a little jealousy, and contempt, and condescension; just as there is jealousy, and contempt, and condescension elsewhere. They are pleasant people, and hospitable, and some of them very distinguished in position or achievement; and I am glad to say I have good friends among them.

But the native is the joy, and the never-ceasing 


\section{AFRICAN CAMP FIRES}

delight. For his benefit is the wide, glittering, colourful, unsanitary bazaar, with its dozens of little open-air veranda shops, its "hotels" where he can sit in a real chair and drink real tea, its cafés, and the dark mysteries of its more doubtful amusements. The bazaar is whack in the middle of town, just where it ought not to be, and it is constantly being quarantined, and threatened with removal. It houses a large population mysteriously, for it is of slight extent. Then on the borders of town are the two great native villages - one belonging to the Somalis; and the other hospitably accommodating the swarms of caravan porters and their families. For, just as in old days Mombasa and Zanzibar used to be the points from which caravans into the interior would set forth, now Nairobi outfits the majority of expeditions. Probably ten thousand picked natives of various tribes are engaged in the profession. Of course but a small proportion of this number is ever at home at any one time; but the village is a large one. Both these villages are built in the native style, of plaster and thatch; have their own headman government - under supervision and are kept pretty well swept out and tidy. Beside these three main gathering places are many camps and "shambas" scattered everywhere; and

*Native farmlets, generally temporary. 


\section{PEOPLE}

the back country counts millions of raw jungle savages, only too glad to drift in occasionally for a look at the metropolis.

At first the newcomer is absolutely bewildered by the variety of these peoples; but after a little he learns to differentiate. The Somalis are perhaps the first recognizable, with their finely chiselled, intelligent, delicate brown features, their slender forms, and their strikingly picturesque costumes of turbans, flowing robes, and embroidered sleeveless jackets. Then he learns to distinguish the savage from the sophisticated dweller of the town. Later comes the identification of the numerous tribes.

The savage comes in just as he has been for, ethnologists alone can guess, how many thousands of years. He is too old an institution to have been affected as yet by this tiny spot of modernity in the middle of the wilderness. As a consequence he startles the newcomer even more than the sight of giraffes on the skyline.

When the shenzi - wild man - comes to town he gathers in two or three of his companions, and presents himself as follows: His hair has been grown quite long, then gathered in three tight pigtails wound with leather, one of which hangs over his forehead, and the other two over his ears. The entire head he has then annointed with a mixture 


\section{AFRICAN CAMP FIRES}

of castor oil and a bright red colouring earth. This is wiped away evenly all around the face, about two inches below the hair, to leave a broad, bandlike, glistening effect around the entire head. The ears are most marvellous. From early youth the lobes have been stretched, until at last they have become like two long elastic loops, hanging down upon the shoulders, and capable of accommodating anything up to and including a tomato can. When in fatigue uniform these loops are caught up over the tops of the ears; but on dress parade they accommodate almost anything considered ornamental. I have seen a row of safety pins clasped in them or a number of curtain rings; or a marmalade jar, or the glittering cover of a tobacco tin. The edges of the ears, all around to the top, are pierced. Then the insertion of a row of long, white, wooden skewers gives one a peculiarly porcupinish look; or a row of little brass danglers hints of wealth. Having thus finished off his head, your savage clasps around his neck various strings of beads; or collars of iron or copper wire, polished to the point of glitter; puts on a half dozen armlets and leglets of the same; ties on a narrow bead belt in which is thrust a short sword; annoints himself all over with reddened castor oil until he glistens and shines in the sun; rubs his legs with white clay and traces patterns therein; seizes 

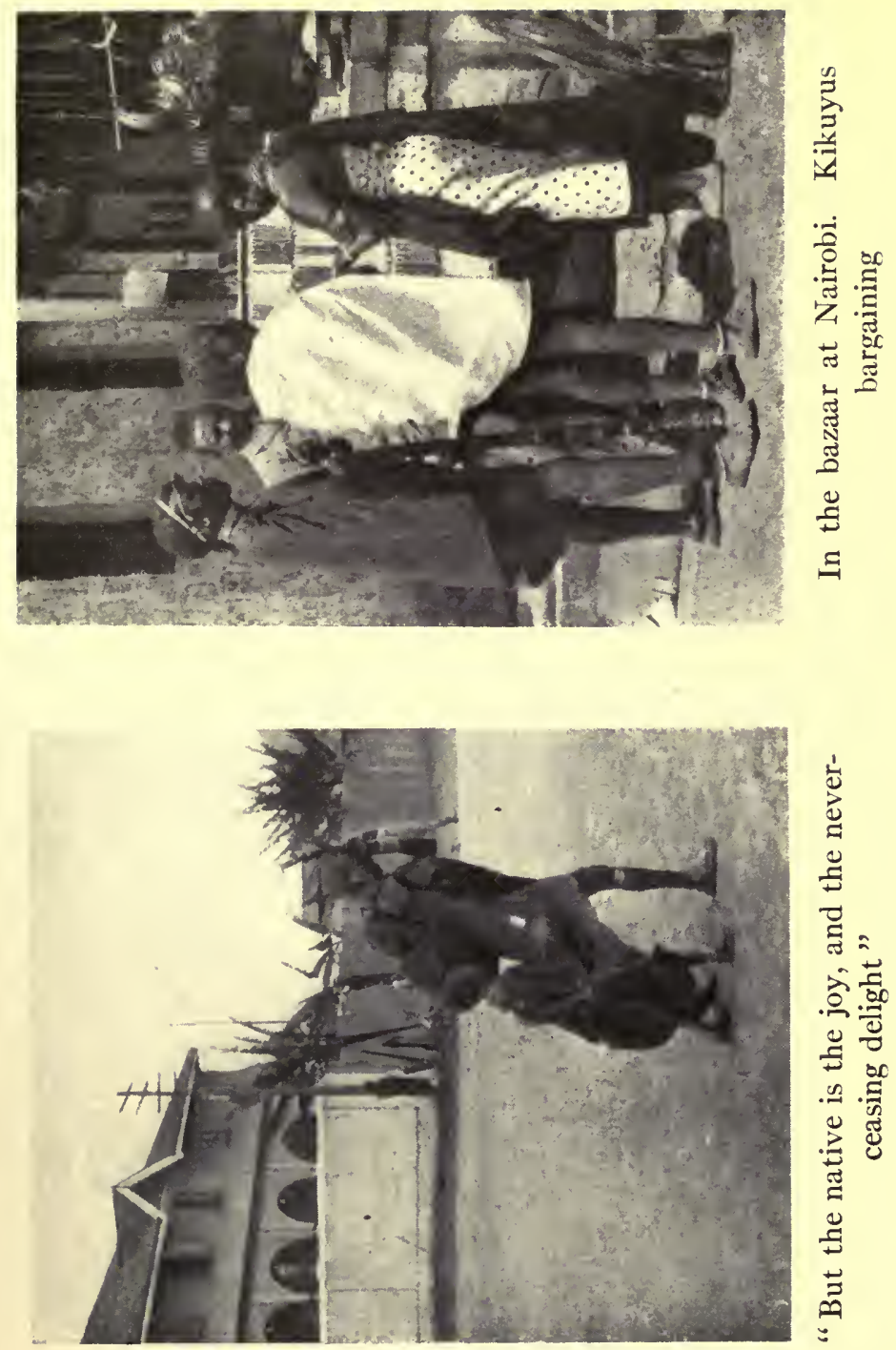


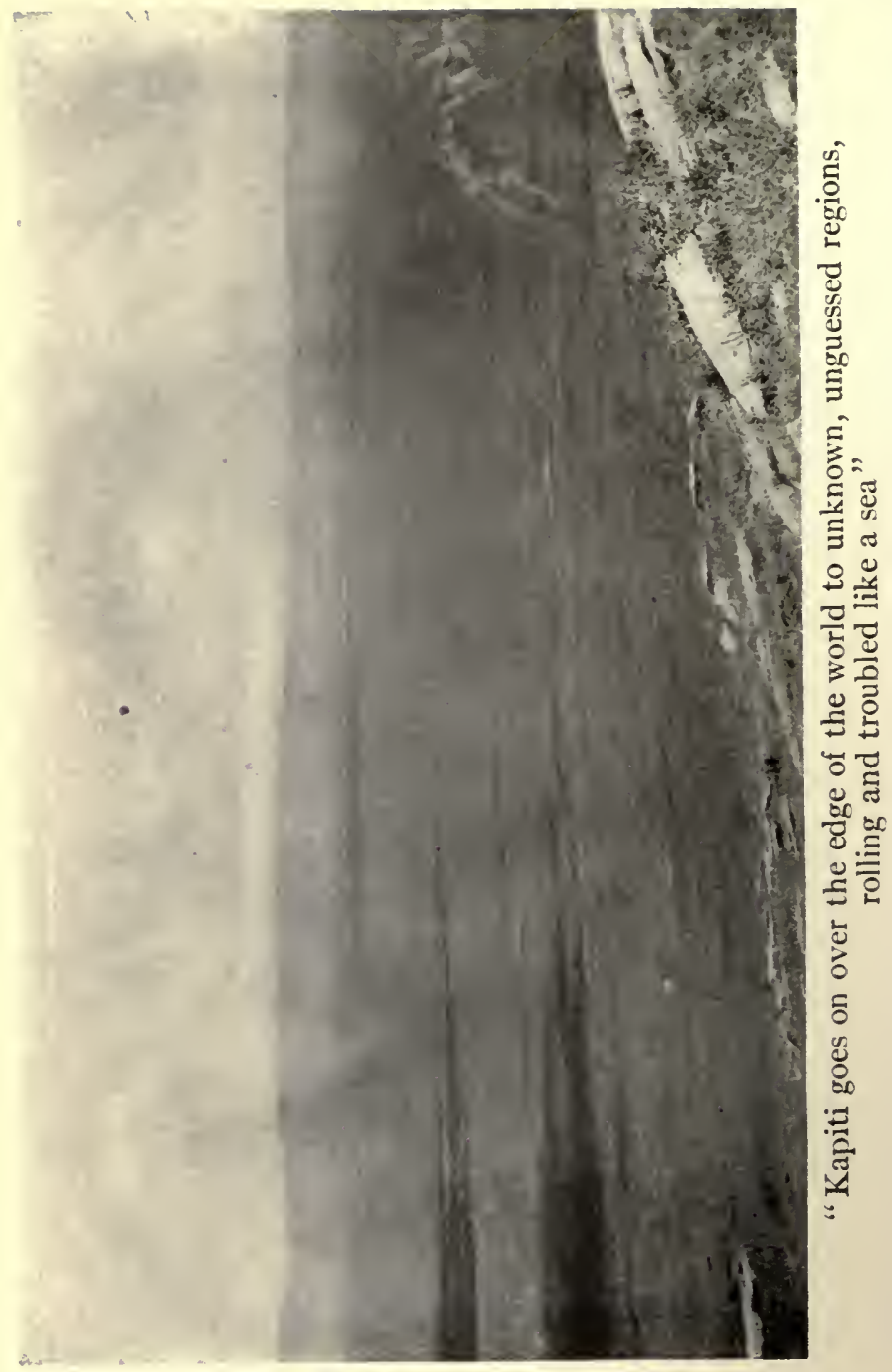




\section{PEOPLE}

his long-bladed spear, and is ready for the city. Oh, no! I forgot - and he probably came near doing so - his strip of 'Mericani.* This was originally white, but constant wear over castor oil has turned it a uniform and beautiful trown.

The purpose of this is ornament, and it is so worn. There has been an attempt, I understand, to force these innocent children to some sort of conventional decency while actually in the streets of Nairobi. It was too large an order. Some bring in clothes, to be sure, because the white man asks it; but why no sensible man could say. They are hung from one shoulder, flap merrily in the breeze, and are always quite frankly tucked up about the neck or under the arms when the wearer happens to be in haste. As a matter of fact, these savages are so beautifully and smoothly formed; their red-brown or chocolatebrown skin is so fine in texture, and their complete unconsciousness so genuine that in an hour the newcomer is quite accustomed to their nakedness.

These proud youths wander mincingly down the street with an expression of the most fatuous and good-natured satisfaction with themselves. To their minds they have evidently done every last thing that human ingenuity or convention could encompass.

*White cotten cloth. 


\section{AFRICAN CAMP FIRES}

They are the dandies, the proud young aristocracy of wealth and importance; and of course they may differ individually or tribally from the sample I have offered. Also there are many other social grades. Those who care less for dress or have less to get it with can rub along very cheaply. The only real essentials are (a) something for the ear - a tomato can will do; (b) a trifle for clothing - and for that a scrap of gunny sacking will be quite enough.

The women to be seen in the streets of Nairobi are mostly of the Kikuyu tribe. They are pretty much of a pattern. Their heads are shaven, either completely or to leave only ornamental tufts; and are generally bound with a fine wire fillet so tightly that the strands seem to sink into the flesh. A piece of cotton cloth, dyed dark umber red, is belted around the waist, and sometimes, but not always, another is thrown about the shoulders. They go in for more hardware than do the men. The entire arms and the calves of the legs are encased in a sort of armour made of quarter-inch wire wound closely. and a collar of the same material stands out like a ruff eight or ten inches around the neck. This is wound on for keeps; and must be worn day and night and all the time, a cumbersome and tremendously heavy burden. A dozen large loops of coloured beads strung through the ears, and various strings 


\section{PEOPLE}

and necklaces of beads, cowrie shells and the like, finish them out in all their gorgeousness. They would sink like plummets. Their job in life, beside lugging all this stuff about, is to carry in firewood and forage. At any time of the day long files of them can be seen bending forward under their burdens. These they carry on their backs by means of a strap across the tops of their heads; after the fashion of the Canadian tump line.

The next cut above the shenzi, or wild man, is the individual who has been on safari as carrier, or has otherwise been much employed around white men. From this experience he has acquired articles of apparel and points of view. He is given to ragged khaki, or cast-off garments of all sorts; but never to shoes. This hint of the conventional only serves to accent the little self-satisfied excursions he makes into barbarism. The shirt is always worn outside, the ear ornaments are as varied as ever, the head is shaved in strange patterns, a tiny tight tuft on the crown is useful as fastening for feathers or little streamers or anything else that will wave or glitter. One of these individuals wore a red label he had with patience and difficulty - removed from one of our trunks. He had pasted it on his forehead; and it read "Baggage Room, Not Wanted." These people are, after all, but modified shenzis. The 


\section{AFRICAN CAMP FIRES}

modification is nearly always in the direction of the comic.

Now we step up to a class that would resent being called shenzis as it would resent an insult. This is the personal servant class. The members are of all tribes, with possibly a slight preponderance of Swahilis and Somalis. They are a very clean, wellgroomed, self-respecting class, with a great deal of dignity and a great deal of pride in their bwanas. Also they are exceedingly likely to degenerate unless ruled with a firm hand and a wise head. Very rarely are they dishonest as respects the possessions of their own masters. They understand their work perfectly, and the best of them get the equivalent of from eight to ten dollars a month. Every white individual has one or more of them; even the tiny children with their ridiculous little sun helmets are followed everywhere by a tall, solemn, white-robed black. Their powers of divination approach the uncanny. About the time you begin to think of wanting something, and are making a first helpless survey of a boyless landscape, your own servant suddenly, mysteriously, and unobtrusively appears from nowhere. Where he keeps himself, where he feeds himself, where he sleeps you do not know. These beautifully clean, trim, dignified people are always a pleasant accent in the varied picture. 


\section{PEOPLE}

The Somalis are a clan by themselves. A few of them condescend to domestic service, but the most prefer the free life of traders, horse dealers, gunbearers, camel drivers, labour go-betweens, and similar guerrilla occupations. They are handsome, dashing, proud, treacherous, courageous, likeable, untrustworthy. They career around on their high, short-stirruped saddles; they saunter indolently in small groups; they hang about the hotel hoping for a dicker of some kind. There is nothing of the savage about them, but much of the true barbarian, with the barbarian's pride, treachery, and love of colour. 


\section{XVI}

\section{RECRUITING}

7 THE traveller Nairobi is most interesting as

1 the point from which expeditions start and to which they return. Doubtless an extended stay in the country would show him that problems of administration and possibilities of development could be even more absorbing; but such things are very sketchy to him at first.

As a usual thing, when he wants porters he picks them out from the throng hanging around the big outfitters' establishments. Each man is then given a blanket - cotton, but of a most satisfying red a tin water bottle, a short stout cord, and a navy blue jersey. After that ceremony he is yours.

But on the occasion of one three months' journey into comparatively unknown country we ran up against difficulties. Some two weeks before our contemplated start two or three cases of bubonic plague had been discovered in the bazaar, and as a consequence Nairobi was quarantined. This meant that a rope had been stretched around the infected 


\section{RECRUITING}

area, that the shops had been closed, and that no native could - officially - leave Nairobi. The latter provision affected us; for under it we should be unable to get our bearers out.

As a matter of fact, the whole performance unofficially - was a farce. Natives conversed affably at arm's length across the ropes; hundreds sneaked in and out of town at will; and from the rear of the infected area I personally saw beds, chests, household goods, blankets, and clothes, passed to friends outside the ropes. When this latter condition was reported, in my presence, to the medical officers, they replied that this was a matter for police cognizance! But the brave outward show of ropes, disinfectants, gorgeous sentries - in front - and official inspection went solemnly on. Great, even in Africa, is the god of red tape.

Our only possible plan, in the circumstances, was to recruit the men outside the town to camp them somewhere, march them across country to a way station and there embark them. Our goods and safari stores we could then ship out to them by train.

Accordingly we rode on bicycles out to the Swahili village.

This is, as I have said, composed of large "beehive" houses thatched conically with straw. The roofs extend to form verandas beneath which sit 


\section{AFRICAN CAMP FIRES}

indolent damsels, their hair divided in innumerable tiny parts running fore and aft like the stripes on a watermelon; their figured 'Mericani garments draped gracefully. As befitted the women of plutocrats, they wore much jewellery, some of it set in their noses. Most of them did all of nothing, but some sat half buried in narrow strips of bright-coloured tissue paper. These they were pasting together like rolls of tape, the coloured edges of the paper forming concentric patterns on the resultant disks - an infinite labour. The disks, when completed, were for insertion in the lobes of the ears.

When we arrived the irregular "streets" of the village were nearly empty, save for a few elegant youths, in long kanzuas, or robes of cinnamon colour and spotless white, on their head's fezzes or turbans, in their hands slender rattan canes. They were very busy talking to each other, and of course did not notice the idle beauties beneath the verandas.

Hardly had we appeared, however, when mysteriously came forth the headman - a bearded, solemn, Arablike person with a phenomenally ugly face but a most pleasing smile. We told him we wanted porters. He clapped his hands. To the four young men who answered this summons he gave a command. From sleepy indolence they sprang into life. To the four cardinal points of the compass 


\section{RECRUITING}

they darted away, running up and down the side streets, beating on the doors, screaming at the tops of their lungs the word "Cazi"* over and over again.

The village hummed like a wasp's nest. Men poured from the huts in swarms. The streets were filled; the idle sauntering youths were swamped and sunk from view. Clamour and shouting arose where before had been a droning silence. The mob beat up to where we stood, surrounding us, shouting at us. From somewhere some one brought an old table and two decrepit chairs, battered and rickety in themselves, but symbols of great authority in a community where nobody habitually used either. Two naked boys proudly took charge of our bicycles.

We seated ourselves.

"Fall in!" we yelled.

About half the crowd fell into rough lines. The rest drew slightly one side. Nobody stopped talking for a single instant.

We arose and tackled our job. The first part of it was to segregate the applicants into their different tribes

"Monumweri hapa!" we yelled; and the command was repeated and repeated again by the headman, by his four personal assistants, by a half dozen lesser headmen. Slowly the Monumwezi drew aside.

"Work. 


\section{AFRICAN CAMP FIRES}

We impressed on them emphatically ther must stay put, and went after, in turn, the Baganda, the Wakamba, the Swahilis, the Kavirondo, the Kikuyu. When we had them grouped, we went over them individually. We punched their chests, we ran over all their joints, we examined their feet, we felt their muscles. Our victims stood rigidly at inspection, but their numerous friends surrounded us closely, urging the claims of the man to our notice. It was rather confusing, but we tried to go at it as though we were alone in a wilderness. If the man passed muster we motioned him to a rapidly growing group.

When we had finished, we had about sixty men segregated. Then we went over this picked lot again. This time we tried not only to get good specimens, but to mix our tribes. At last our count of twenty-nine was made up, and we took a deep breath. But to us came one of them complaining that he was a Monumwezi, and that we had picked only three Monumwezi, and - We cut him short. His contention was quite correct. A porter tent holds five, and it does not do to mix tribes. Reorganization! Cut out two extra Kavirondos, and include two more Monumwezi. "Bass! finished!" Now go get your effects. We start immediately.

As quickly as it had filled, the street cleared. The rejected dove back into their huts, the newly 


\section{RECRUITING}

enlisted carriers went to collect their baggage. Only remained the headman and his fierce-faced assistants, and the splendid youths idling up and down - none of them had volunteered, you may be sure - and the damsels of leisure beneath the porticos. Also one engaging and peculiar figure hovering near.

This individual had been particularly busy during our recruiting. He had hustled the men into line, he had advised us for or against different candidates, he had loudly sung my praises as a man to work for, although, of course, he knew nothing about me. Now he approached, saluted, smiled. He was a tall, slenderly built person, with phenomenally long, thin legs, slightly rounded shoulders, a forward thrust, keen face, and remarkably long, slim hands. With these he gesticulated much, in a right-angled fashion, after the manner of Egyptian hieroglyphical figures. He was in no manner shenzi. He wore a fez, a neat khaki coat and shorts, blue puttees and boots. Also a belt with leather pockets, a bunch of keys, a wrist watch and a seal ring. His air was of great elegance and social ease. We took him with us as Cuninghame's gunbearer. He proved staunch, a good tracker, an excellent hunter, and a most engaging individual. His name was Kongoni, and he was a Wakamba. 


\section{AFRICAN CAMP FIRES}

But now we were confronted with a new problem: that of getting our twenty-nine chosen ones together again. They had totally disappeared. In all directions we had emissaries beating up the laggards. As each man reappeared carrying his little bundle, we lined him up with his companions. Then when we turned our backs we lost him again; he had thought of another friend with whom to exchange farewells. At the long last however, we got them all collected. The procession started, the naked boys proudly wheeling our bikes alongside. We saw them fairly clear of everything, then turned them over to Kongoni, while we returned to Nairobi to see after our effects. 


\section{PAR'T IV}

A LION HUNT ON KAPITI 



\section{XVII}

\section{AN OSTRICH FARM AT MACHAKOS}

THIS has to do with a lion hunt on the Kapiti

Plains. On the veranda at Nairobi I had some time previous met Clifford Hill, who had invited me to visit him at the ostrich farm he and his cousin were running in the mountains near Machakos. Some time later, a visit to Juja Farm gave me the opportunity. Juja is only a day's ride from the Hills'. So an Africander, originally from the south, Captain Duirs, and I sent across a few carriers with our personal effects, and ourselves rode over on horseback.

Juja is on the Athi Plains. Between the Athi and Kapiti Plains runs a range of low mountains around the end of which one can make his way as around a promontory. The Hills' ostrich farm was on highlands in the bay the other side of the promontory.

It was toward the close of the rainy season, and the rivers were up. We had to swim our horses within a half mile of Juja, and got pretty wet. Shortly after crossing the Athi, however, five miles 


\section{AFRICAN CAMP FIRES}

on, we emerged on the dry, drained slopes from the hills. Here the grass was long, and the ticks plenty. Our horses' legs and chests were black with them; and when we dismounted for lunch we ourselves were almost immediately alive with the pests. In this very high grass the game was rather scarce, but after we had climbed by insensible grades to the shorter growth we began to see many hartebeeste, zebra, and gazelles, and a few of the wildebeeste, or brindled gnus. Travel over these great plains, and through these leisurely low hills is a good deal like coastwise sailing; the same apparently unattainable landmarks which, nevertheless, are at last passed and left astern by the same sure but insensible progress. Thus we drew up on apparently continuous hills, found wide gaps between them, crossed them, and turned to the left along the other side of the promontory. About five o'clock we came to the Hills'.

The ostrich farm is situated on the very top of a conical rise that sticks up like an island close inshore to the semicircle of mountains in which end the vast plains of Kapiti. Thus the Hills have at their backs and sides these solid ramparts and face westward the immensities of space. For Kapiti goes on over the edge of the world to unknown, unguessed regions, rolling and troubled like a sea. And from that 


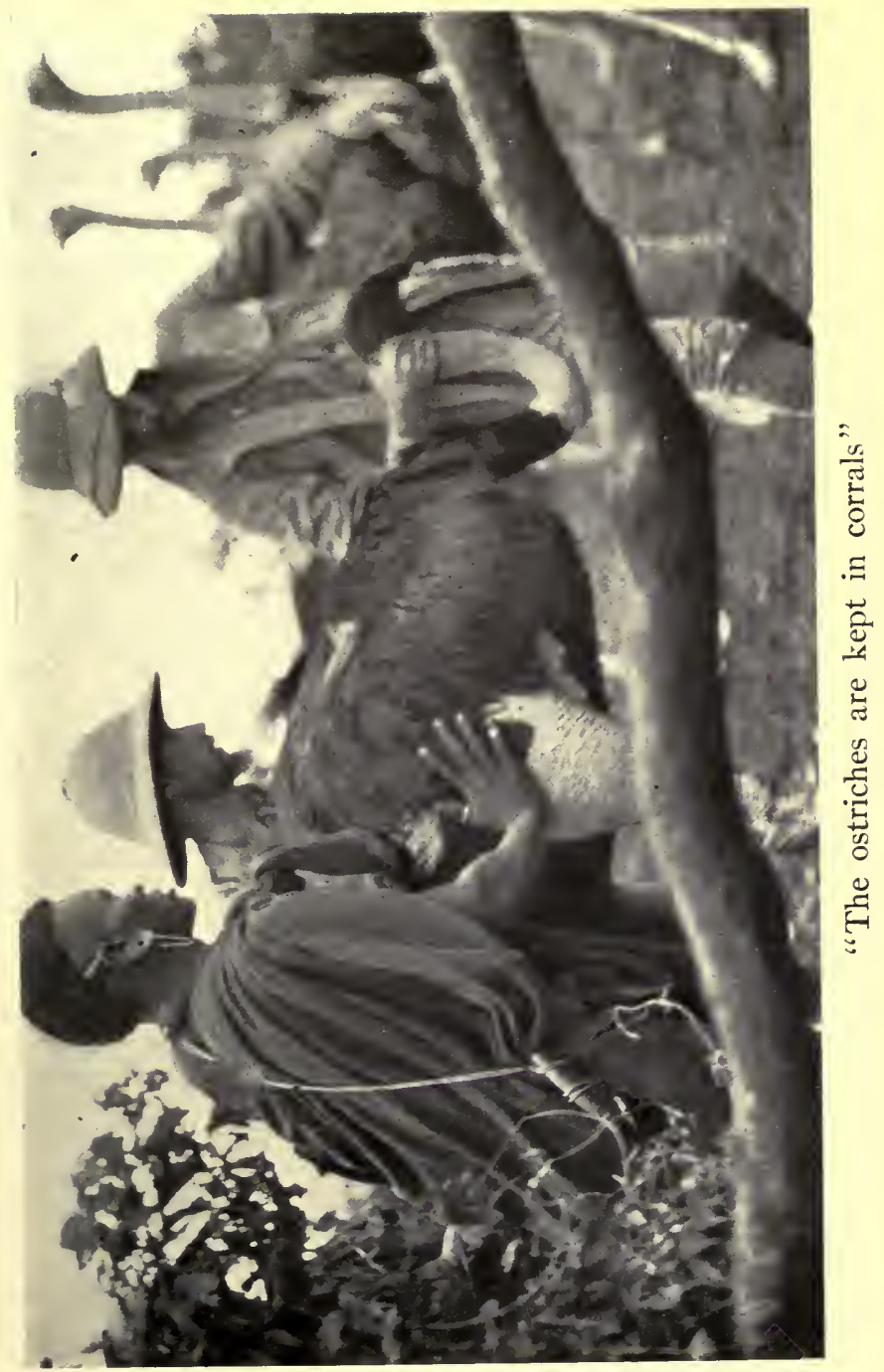




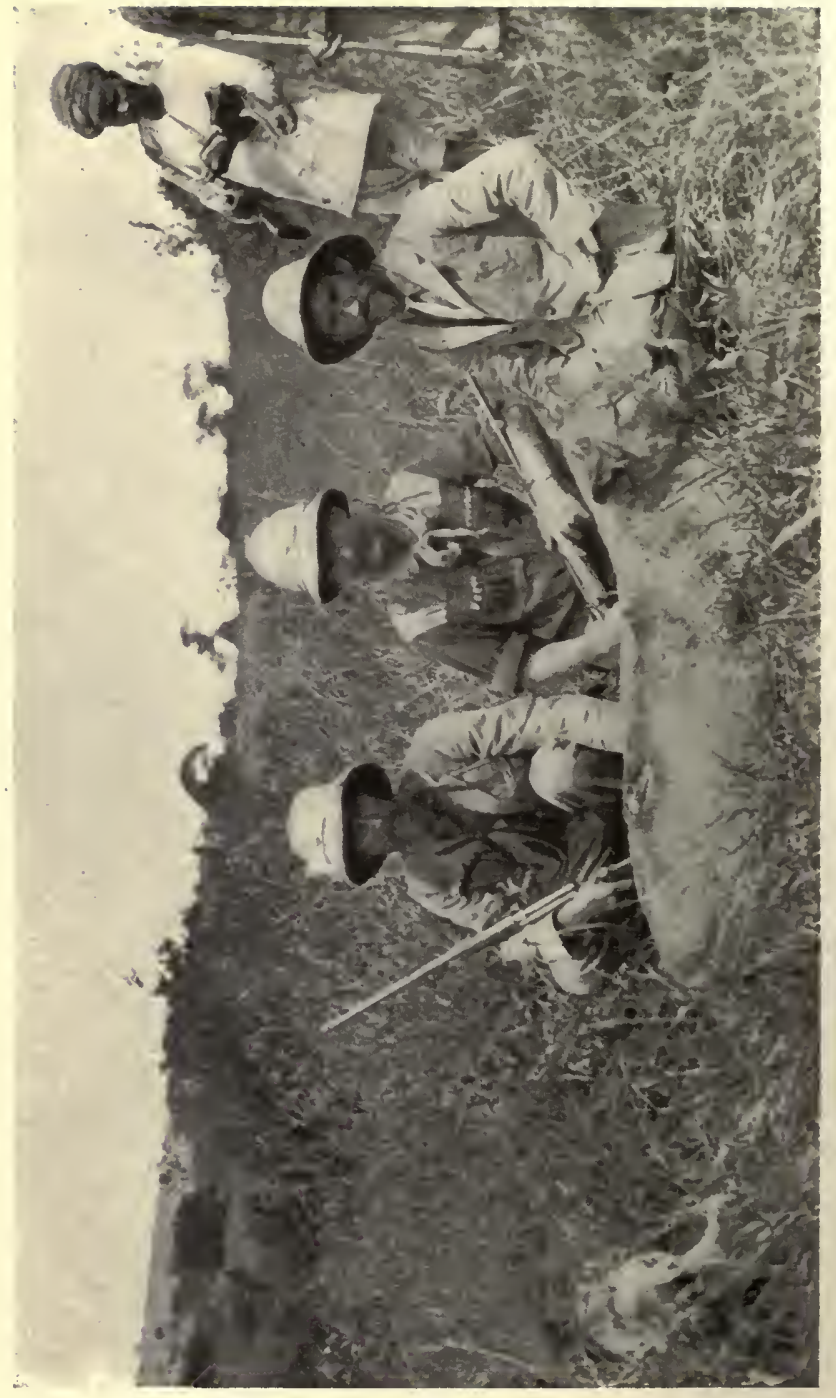

2

อ

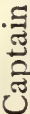

롤

$\stackrel{\infty}{=}$

름

กิ

ฮำ

4

$\exists$

E : 


\section{AN OSTRICH FARM AT MACHAKOS}

unknown, on very still days, the snowy peak of Kilimanjaro peers out, sketched as faintly against the sky as a soap bubble wafted upward and about to disappear. Here and there on the plains kopjes stand like islands, their stone tops looking as though thrust (from beneath) through the smooth prairie surface. To them meandered long, narrow ravines full of low brush, like thin, wavering streaks of gray. On these kopjes - each of which had its nameand in these ravines we were to hunt the lions.

We began the ascent of the cone on which dwelt our hosts. It was one of those hills that seem in no part steep, and yet which finally succeed in raising one to a considerable height. We passed two ostrich herds in charge of savages, rode through a scattered native village, and so came to the farm itself, situated on the very summit.

The house consisted of three large circular huts, thatched neatly with papyrus stalks, and with conical roofs. These were arranged as a triangle, just touching each other; and the space between had been roofed over to form a veranda. We were ushered in to one of these circular rooms. It was spacious and contained two beds, two chairs, a dresser, and a table. Its earth floor was completely covered by the skins of animals. In the corresponding room, opposite, slept our hosts; while the third 


\section{AFRICAN CAMP FIRES}

hut was the living and dining-room. A long table, rawhide bottomed chairs, a large sideboard, bookcases, a long easy settee with pillows, gun racks, photographs in and out of frames, a table with writing materials, and books and magazines everywhere not to speak of again the skins of many animals completely covering the floor. Out behind, in small separate buildings functioned the cook, and dwelt the stores, the bathtub, and other such necessary affairs.

As soon as we had consumed the usual grateful lime juice and sparklets, we followed our hosts into open air to look around.

On this high, airy hilltop the Hills some day are going to build them a real house. In anticipation they have laid out grounds and have planted many things. In examining these my California training stood by me. Out there, as here, one so often examines his own and his neighbours' gardens not for what they are but for what they shall become. His imagination can exalt this tiny seedling to the impressiveness of spreading noontime shade; can magnify yonder apparent duplicate to the full symmetry of a shrub; can ruthlessly diminish the present importance of certain grand and lofty growths to their true status of flower or annual. So from a dead uniformity of size he casts forward in 


\section{AN OSTRICH FARM AT MACHAKOS}

the years to a pleasing variation of shade, of jungle, of open glade, of flowered vista; and he goes away full of expert admiration for "X.'s bully garden." With this solid training beneath me I was able on this occasion to please immensely.

From the house site we descended the slope to where the ostriches and the cattle and the people were in the last sunlight swarming upward from the plains pastures below. These people were to the most extent Wakamba, quite savage, but attracted here by the justness and.fair dealing of the Hills. Some of them farmed on shares with the Hills, the white men furnishing the land and seed, and the black men the labour; some of them laboured on wage; some few herded cattle or ostriches; some were hunters, and took the field only when, as now, serious business was afoot. They had their complete villages, with priests, witch doctors, and all; and they seemed both contented and fond of the two white men.

As we walked, about we learned much of the ostrich business; and in the course of our ten days' visit we came to a better realization of how much there is to think of in what appears basically so simple a proposition.

In the nesting time, then, the Hills went out over the open country, sometimes for days at a time, 


\section{AFRICAN CAMP FIRES}

armed with long high-power telescopes. With these fearsome and unwieldy instruments they surveyed the country inch by inch from the advantage of a kopje. When thus they discovered a nest, they descended and appropriated the eggs. The latter, hatched at home in an incubator, formed the nucleus of a flock.

Pass the raising of ostrich chicks to full size through the difficulties of disease, wild beasts, and sheer cussedness. Of the resultant thirty birds or so of the season's catch but two or three will even promise good production. These must be bred in captivity with other likely specimens. Thus after several years the industrious ostrich farmer may become possessed of a few really prime birds. To accumulate a proper flock of such in a new country is a matter of a decade or so. Extra prime birds are as well known, and as much in demand for breeding as any blooded horse in a racing country. Your true ostrich enthusiast, like the Hills, possesses trunks full of feathers, not good commercially, but intensely interesting for comparison and for the purposes of prophecy. While I stayed with them came a rumour of a very fine plucking a distant neighbour had just finished from a likely two-yearold. The Hills were manifestly uneasy until one of them had ridden the long distance to compare 


\section{AN OSTRICH FARM AT MACHAKOS}

this newcomer's product with that of their own twoyear-olds. And I shall never forget the reluctantly admiring shake of the head with which he acknowlledged that it was indeed a "very fine feather!"

But getting the birds is by no means all of ostrich farming, as many eager experimenters have discovered to their cost. The birds must have a certain sort of pasture land; and their paddocks must be built on an earth that will not soil or break the edges of the new plumes.

And then there is the constant danger of wild beasts. When a man has spent years in gathering suitable flocks, he cannot be blamed for wild anger when, as happened while I was in the country, lions kill sixty or seventy birds in a night. The ostrich seems to tempt lions greatly. The beasts will make their way through and over the most complicated defences. Any ostrich farmer's life is a constant warfare against them. Thus the Hills had slain sixty-eight lions in and near their farm a tremendous record. Still the beasts continued to come in. My hosts showed me with considerable pride their arrangements finally evolved for night protection.

The ostriches were confined in a series of heavy corrals segregating the birds of different ages. Around the outside of this group of enclosures ran 


\section{AFRICAN' CAMP FIRES}

a wide ring corral in which were confined the numerous cattle; and as an outer wall to this were built the huts of the Wakamba village. Thus to penetrate to the ostriches the enterprising lion would have to pass both the people, the cattle, and the strong thorn and log structures that contained them.

This subject brings me to another set of acquaintances we had already made - the dogs.

These consisted of an Airedale named Ruby; two setters called Wayward and Girlie; a heavy black mongrel, Nero; ditto brindle, Ben; and a smaller black and white ditto, Ranger. They were very nice, friendly doggy dogs, but they did not look like lion hunters. Nevertheless, Hill assured us that they were of great use in the sport, and promised us that on the following day we should see just how. 


\section{XVIII}

\section{THE FIRST LIONESS}

$\Delta \mathrm{T}$ AN early hour we loaded our bedding, food, 1 tents, and camp outfit on a two-wheeled wagon drawn by four of the humpbacked native oxen, and sent it away across the plains with instructions to make camp on a certain kopje. Clifford Hill and myself, accompanied by our gunbearers and syces, then rode leisurely down the length of a shallow brushy cañon for a mile or so. There we dismounted and sat down to await the arrival of the others. These - including Harold Hill, Captain Duirs, five or six Wakamba spearmen, our own carriers, and the dogs - came along more slowly, beating the bottoms on the off chance of game.

The sun was just warming, and the bees and insects were filling the air with their sleepy droning sounds. The sidehill opposite showed many little outcrops of rocks so like the hills of our own Western States that it was somewhat difficult to realize that we were in Africa. For some reason the delay was long. Then suddenly all four of us simultaneously 


\section{AFRICAN CAMP FIRES}

saw the same thing. A quarter mile away and on the sidehill opposite a magnificent lioness came loping easily along through the grass. She looked very small at that distance, like a toy, and quite unhurried. Indeed, every few moments she paused to look back in an annoyed fashion over her shoulder in the direction of the row behind her.

There was nothing to do but sit tight and wait. The lioness was headed exactly to cross our front; nor, except at one point, was she at all likely to deviate. A shallow tributary ravine ran into our own about two hundred yards away. She might possibly sneak down the bed of this. It seemed unlikely. The going was bad, and in addition she had no idea as yet that she had been sighted. Indeed, the chances were that she would come to a definite stop before making the crossing, in which case we would get a shot.

"And if she does go down the donga," whispered Hill, "the dogs will locate her."

Sitting still while things approach is always exciting. This is true of ducks; but when you multiply ducks by lions it is still more true. We all crouched very low in the grass. She leaped without hesitation into the ravine - and did not emerge.

This was a disappointment. We concluded she must have entered the stream bottom, and were 


\section{THE FIRST LIONESS}

just about to move when Memba Sasa snapped his fingers. His sharp eyes had discovered her sneaking along, belly to the ground, like the cat she was. The explanation of this change in her gait was simple. Our companions had rounded the corner of the hill and were galloping in plain view a half mile away. The lioness had caught sight of them.

She was gliding by, dimly visible, through thick brush seventy yards distant. Now I could make out a tawny patch that faded while I looked; now I could merely guess at a melting shadow.

"Stir her up," whispered Hill. "Never mind whether you hit. She'll sneak away."

At the shot she leaped fully out into the open with a snarl. Promptly I planted a Springfield bullet in her ribs. She answered slightly to the hit but did not shift position. Her head up, her tail thrashing from side to side, her ears laid back, she stood there looking the landscape over carefully point by point. She was searching for us, but as yet could not locate us. It was really magnificent.

I attempted to throw in another cartridge, but because of my desire to work the bolt quietly, in order not to attract the lioness's attention, I did not pull it back far enough, and the cartridge jammed in the magazine. As evidence of Memba Sasa's coolness and efficiency, it is to be written that he 


\section{AFRICAN CAMP FIRES}

became aware of this as soon as I did. He thrust the .405 across my right side, at the same time withdrawing the Springfield on the left. The motion was slight, but the lioness caught it. Immediately she dropped her head and charged.

For the next few moments, naturally, I was pretty intent on lions. Nevertheless a corner of my mind was aware of Memba Sasa methodically picking away at the jammed rifle, and paying no attention whatever to the beast. Also I heard Hill making picturesque remarks about his gunbearer, who had bolted with his second gun.

The lioness charged very fast, but very straight, about in the tearing, scrambling manner of a terrier after a thrown ball. I got in the first shot as she came, the bullet ranging back from the shoulder and Hill followed it immediately with another from his .404 Jeffrey. She growled at the bullets, and checked very slightly as they hit, but gave no other sign. Then our second shots hit her both together. The mere shock stopped] her short, but recovering instantly, she sprang forward again. Hill's third shot came next, and perceptibly slowed and staggered but did not stop her. By this time she was quite close, and my own third shot reached her brain. She rolled over dead.

Decidedly she was a game beast, and stood more 


\section{THE FIRST LIONESS}

hammering than any other lion I killed or saw killed. Before the final shot in the brain she had taken one light bullet and five heavy ones with hardly a wince. Memba Sasa uttered a loud grunt of satisfaction when she went down for keeps. He had the Springfield reloaded and cocked, right at my elbow.

Hill's gunboy hovered uncertainly some distance in the rear. The sight of the charging lioness had been too much for him and he had bolted. He was not actually up a tree; but he stood very near one. He lost the gun and acquired a swift kick.

Our friends and the men now came up. The dogs made a great row over the dead lioness. She was measured and skinned to accompaniment of the usual low-hummed chantings. We had with us a small boy of ten or twelve years whose job it was to take care of the dogs and to remove ticks. In fact he was known as the Tick Toto. As this was his first expedition afield, his father took especial pains to smear him with fat from the lioness. This was to make him brave. I am bound to confess the effect was not immediate. 


\section{XIX \\ THE DOGS}

T SOON discovered that we were hunting lions 1 with the assistance of the dogs; not that the dogs were hunting lions. They had not lost any lions, not they! My mental pictures of the snarling, magnificent king of beasts surrounded by an equally snarling, magnificent pack vanished into thin air.

Our system was to cover as much likely country as we could, and to let the dogs have a good time. As I have before indicated, they were thoroughly doggy dogs, and interested in everything - except able-bodied lions. None of the stick-at-your-heels in their composition. They ranged far and wide through all sorts of cover seeking what they could find in the way of porcupines, mongoose, hares, birds, cats and whatever else should interest any healthy-minded dog. If there happened to be any lions in the path of these rangings, the dogs retired rapidly, discreetly, and with every symptom of horrified disgust. If a dog came sailing out of a 


\section{THE DOGS}

thicket, ki-yi-ing agitatedly, and took up his position, tail between his legs, behind his master, we knew there was probably a lion about. Thus we hunted lions with dogs.

But in order to be fair to these most excellent canines, it should be recorded that they recovered a certain proportion of their nerve after a rifle had been fired. They then returned warily to the not attack - reconnaissance. This trait showed touching faith, and was a real compliment to the marksmanship of their masters. Some day it will be misplaced. A little cautious scouting on their part located the wounded beast; whereupon, at a respectful distance, they lifted their voices. As a large element of danger in case of a wounded lion is the uncertainty as to his whereabout, it will be seen that the dogs were very valuable indeed. They seemed to know exactly how badly hit an animal might happen to be, and to gauge their distance accordingly, until at last, when the quarry was hammered to harmlessness, they closed in and began to worry the nearly lifeless carcass. By this policy the dogs had a lot of fun hunting on their own hook, preserved their lives from otherwise inevitable extinction, and were of great assistance in saving their masters' skins.

One member of the pack, perhaps two, were, 


\section{AFRICAN CAMP FIRES}

however, rather pathetic figures. I refer to the setters, Wayward and Girlie. Ranger, Ruby, Ben, and Nero scampered merrily over the landscape after anything that stirred, from field mice to serval cats. All was game to their catholic tastes; and you may be sure, in a country like Africa, they had few dull moments. But Wayward and Girlie had been brought up in a more exclusive manner. Their instincts had been supplemented by a rigorous early training. Game to them meant birds, and birds only. Furthermore, they had been solemnly assured by human persons in whom they had the utmost confidence that but one sequence of events was permissible or even thinkable in the presence of game. The Dog at first intimation by scent must convey the fact to the Man, must proceed cautiously to locate exactly, must then stiffen to a point which he must hold staunchly, no matter how distracting events might turn out, of how long an interval might elapse. The Man must next walk up the birds; shoot at them, perhaps kill one, then command the Dog to retrieve. The Dog must on no account move from his tracks until such command is given. All the affair is perfectly simple; but quite inflexible. Any variation in this procedure fills the honest bird dog's mind with the same horror and dismay experienced by a well-brought-up young 


\section{THE DOGS}

man who discovers that he has on shoes of the wrong colour. It isn't done, you know.

Consider then Wayward and Girlie in a country full of game birds. They quarter wide to right, then cross to left, their heads high, their feather tails waving in the most approved good form. When they find birds they draw to their points in the best possible style; stiffen out - and wait. It is now, according to all good ethics, up to the Man. And the Man and his companions go right on by, paying absolutely no attention either to the situation or our own magnificent piece of work! What is one to conclude? That our early training is all wrong? that we are at one experience to turn apostate to the settled and only correct order of things? Or that our masters are no gentlemen. That is a pretty difficult thing, an impossible thing, to conclude of one's own master. But it leaves one in a fearful state mentally; and one has no idea of what to do!

Wayward was a perfect gentleman, and he played the game according to the very best traditions. He conscientiously pointed every bird he could get his nose on. Furthermore he was absolutely staunch and held his point even when the four non-bird dogs rushed in ahead of him. The expression of puzzlement, grief, shock and sadness in his eyes deepened as bird after bird soared awav without a shot. 


\section{AFRICAN CAMP FIRES}

Girlie was more liberal-minded. She pointed her birds, and backed Wayward at need, but when the other dogs rushed her point, she rushed too. And when we swept on by her, leaving her on point; instead of holding it quixotically, as did Wayward, until the bird sneaked away; she merely waited until we were out of sight, and then tried to catch it. Finally Captain Duirs remarked that lions or no lions he was not going to stand it any longer. $\mathrm{He}$ got out a shotgun and all one afternoon killed grouse over Wayward, to the latter's intense relief. His ideals had been rehabilitated. 


\section{$\mathrm{XX}$ \\ BONDONI}

W ${ }^{\mathrm{E}}$ followed many depressions, in which might be lions, until about three o'clock in the afternoon. Then we climbed the gently rising long slope that culminated, far above the plains, in the peak of a hill called Bondoni. From a distance it was steep and well defined; but, like most of these larger kopjes, its actual ascent, up to the last few hundred feet, was so gradual that we hardly knew we were climbing. At the summit we found our men and the bullock cart. There also stood an oblong blockhouse of stone, the walls two feet thick and ten feet high. It was entered only by a blind angle passage; and was strong enough apparently to resist small artillery. This structure was simply an ostrich corral! and bitter experience had shown the massive construction absolutely necessary as adequate protection, in this exposed and solitary spot, against the lions.

We had some tea and bread and butter, and then Clifford Hill and I set out afoot after meat. Only 


\section{AFRICAN CAMP FIRES}

occasionally do these hard-working settlers get a chance for hunting on the plains so near them; and now they had promised their native retainers that they would send back a treat of game. To carry this promised luxury a number of the villagers had accompanied the bullock wagon. As we were to move on next day, it became very desirable to get the meat promptly while still near home.

We slipped over to the other side, and by good fortune caught sight of a dozen zebras feeding in scrub halfway down the hill. They were out of their proper environment up there, but we were glad of it. Down on our tummies then we dropped; and crawled slowly forward through the high, sweet grasses. We were in the late afternoon shadow of the hill, and we enjoyed the mild skill of the stalk. Taking advantage of every cover, slipping over into little ravines, lying very flat when one of the beasts raised his head, we edged nearer and nearer. We were already well within range, but it amused us to play the game. Finally, at one hundred yards, we came to a halt. The zebra showed very handsome at that range, for even their smaller leg stripes were all plainly visible. Of course at that distance there could be small chance of missing, and we downed one each. The Wakamba, who had been watching eagerly, swarmed down shouting. 


\section{BONDONI}

We dined just at sunset under a small tree at the very top of the peak. Long bars of light shot through the western clouds; the plain turned from solid earth to a mysterious sea of shifting twilights; the buttes stood up wrapped in veils of soft desert colours; Kilimanjaro hung suspended like a rosecoloured bubble above the abyss beyond the world. 


\section{XXI \\ RIDING THE PLAINS}

$\mathrm{F}^{\mathrm{ROM}}$ the mere point of view of lions, lion F hunting was very slow work indeed. It meant riding all of long days, from dawn until dark, investigating miles of country that looked all alike and in which we seemed to get nowhere. One by one the long billows of plain fell behind, until our camphill had turned blue behind us, and we seemed to be out in illimitable space, with no possibility, in an ordinary lifetime, of ever getting in touch with anything again. What from above had looked as level as a floor now turned into a tremendously wide and placid ground swell. As a consequence we were always going imperceptibly up and up and up to a long-delayed skyline, or tipping as gently down the other side of the wave. From crest to crest of these long billows measured two or three miles. The vertical distance in elevation from trough to top was perhaps not over fifty to onehundred feet.

Slowly we rode along the shallow grass and brush I64 


\section{RIDING THE PLAINS}

ravines in the troughs of the low billows, while the dogs worked eagerly in and out of cover, and our handful of savages cast stones and shouted. Occasionally we divided forces and beat the length of a hill, two of us lying in wait at one end for the possible lion, the rest sweeping the sides and summits. Many animals came bounding along, but no lions. Then Harold Hill, unlimbering a huge, many-jointed telescope, would lie flat on his back and sight the fearsome instrument over his crossed feet, in a general bird's eye view of the plains for miles around. While he was at it we were privileged to look about us less under the burden of responsibility. We could make out the game as little, light-coloured dots and speckles, thousands upon thousands of them, thicker than cattle ever grazed on the open range, and as far as the eye could make them out, and then a glance through our glasses picked them up again for mile after mile. Even the six-power could go no farther. The imagination was left the vision of more leagues of wild animals even to the half-guessed azure mountains - and beyond. I had seen abundant game elsewhere in Africa, but nothing like the multitudes inhabiting the Kapiti Plains at that time of year. In other seasons this locality is comparatively deserted.

The 'scope revealing nothing in our line, we rode 


\section{AFRICAN CAMP FIRES}

again to the lower levels, and again took up our slow, painstaking search.

But although three days went by in this manner without our getting a glimpse of lions, they were far from being days lost. Minor adventure filled our hours. What elsewhere would be major interest of strange and interesting experience met us at every turn. The game, while abundant, was very shy. This had nothing to do with distrust of hunters; but merely to the fact that it was the season of green grass. We liked to come upon animals unexpectedly, to see them buck-jump and cavort.

Otherwise we rode in a moving space cleared of animals, the beasts unobtrusively giving way before us, and as unobtrusively closing in behind. The sun flashed on the spears of savages travelling single file across the distance. Often we stopped short to gaze upon a wild and tumbled horizon of storm that Gustave Doré might have done.

The dogs were always joyously routing out some beast, desirable from their point of view, and chasing it hopelessly about, to our great amusement. Once they ran into a giant porcupine - about the size a setter would be with shorter legs - which did not understand running away. They came upon it in a dense thicket, and the ensuing row was unholy. They managed to kill the porcupine among them, 


\section{RIDING THE PLAINS}

after which we plucked barbed quills from some very grieved dogs. The quills were large enough to make excellent penholders. The dogs also swore by all canine gods that they wouldn't do a thing to a hyena, if only they could get hold of one. They never got hold of one, for the hyena is a coward. His skull and teeth, however, are as big and powerful as those of a lioness; so I do not know which was luckiest in his avoidance of trouble - he or the dogs.

Nor from the shooting standpoint did we lack for sport. We had to shoot for our men; and we occasionally needed meat ourselves. It was always interesting, when such necessities arose, to stalk the shy bucks and do long-range rifle practice. This shooting, however, was done only after the day's hunt was over. We had no desire to spoil our lion chances.

The long circle toward our evening camp always proved very long indeed. We arrived at dusk to find supper ready for us. As we were old campaigners we ate this off chop boxes as tables, and sat on the ground. It was served by a Wakamba youth we had nicknamed Herbert Spencer, on account of his gigantic intellect. Herbert meant well, but about all he succeeded in accomplishing was a pathetically wrinkled brow of care and scared eyes. He had never been harshly treated by any of us, 


\section{AFRICAN CAMP FIRES}

but he acted as though always ready to bolt. If there were twenty easy right methods of doing a thing and one difficult wrong method, Herbert would get the latter every time. No amount of experience could teach him the logic of our simplest ways. One evening he brought a tumbler of mixed water and condensed milk. Harold Hill glanced into the receptacle.

"Stir it," he commanded briefly.

Herbert Spencer obeyed. We talked about something else. Some five or ten minutes later one of us noticed that Herbert was still stirring, and called attention to the fact. When the latter saw our eyes were on him he speeded up until the spoon fairly rattled in the tumbler. Then when he thought our attention had relaxed again, he relaxed also his efforts. The spoon travelled slower and slower in its dreamy circle. We amused ourselves for some time thus. Then we became so weak from laughter that we fell backward off our seats and some one gasped a command that Herbert cease.

I am afraid, after a little, that we rather enjoyed mildly tormenting poor Herbert Spencer. He tried so hard, and looked so scared, and was so unbelievably stupid! Almost always he had to pick his orders word by word from a vast amount of highflown, unnecessary English. 


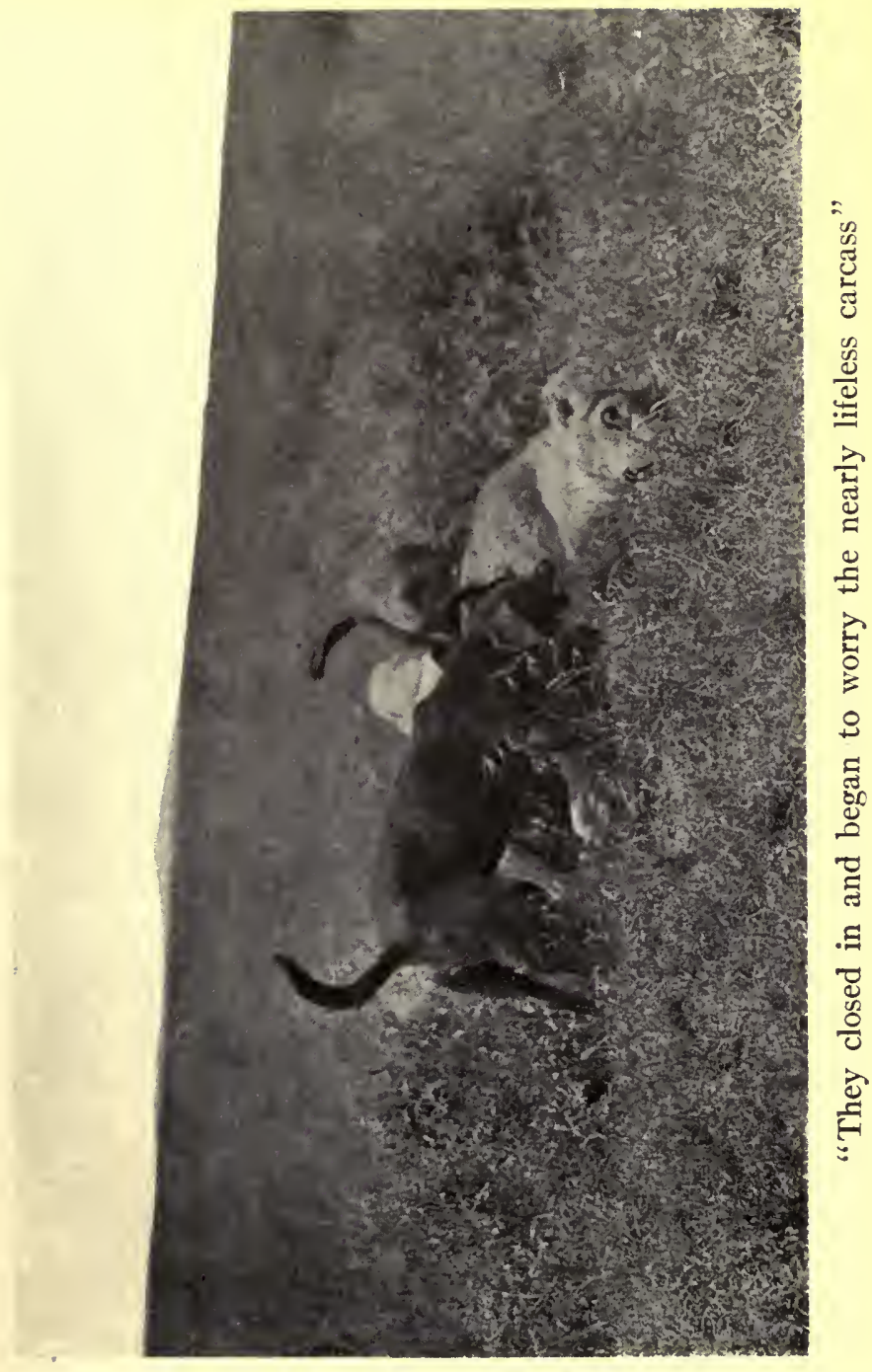




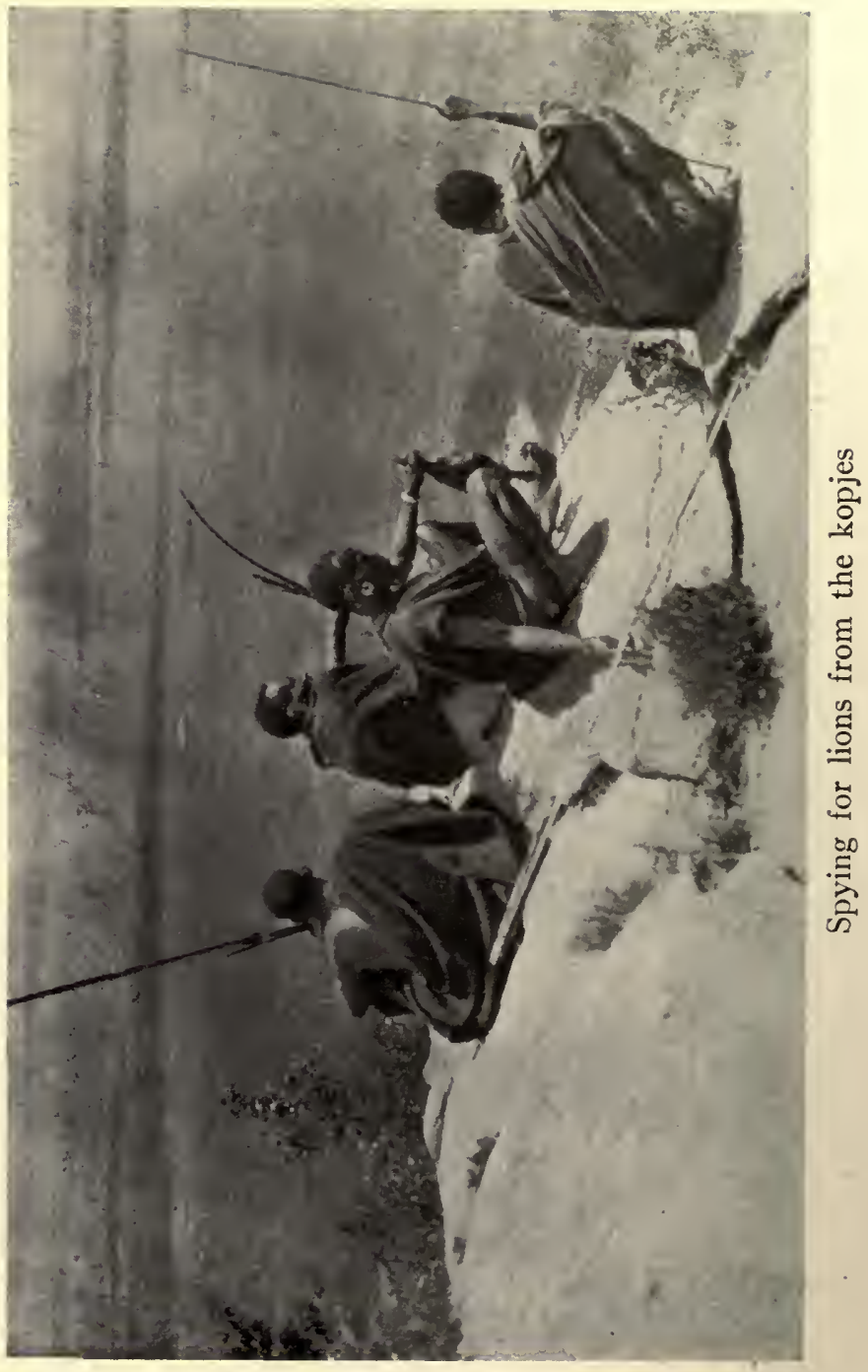




\section{RIDING THE PLAINS}

"O Herbert Spencer," the command would run, "if you would condescend to bend your mighty intellect to the lowly subject of maji, and will snatch time from your profound cerebrations to assure its being moto sana, I would esteem it infinite condescension on your part to lete pesi pesi."

And Herbert, listening to all this with a painful, strained intensity, would catch the six key words, and would falter forth a trembling " $N$ 'dio bwana."

Somewhere down deep within Herbert Spencer's make up, however, was a moral sense of duty. When we finally broke camp for keeps, on the great hill of Lucania, Herbert Spencer, relieved from his job, bolted like a shot. As far as we could see him he was running at top speed. If he had not possessed a sense of duty, he would have done this long ago.

We camped always well up on some of the numerous hills; for, although anxious enough to find lions in the daytime, we had no use for them at all by night. This usually meant that the boys had to carry water some distance for the benefit of the dogs. We kept a canvas bathtub full from which they could drink at any time. This necessary privilege after a hard day nearly drove Captain Duirs crazy. It happened like this:

We were riding along the slope of a sidehill, when in the ravine, a half mile away and below us, we 


\section{AFRICAN CAMP FIRES}

saw something dark pop up in sight and then down again. We shouted to some of the savage Wakamba to go investigate. They closed in from all sides, their long spears poised to strike. At the last moment out darted, not an animal, but a badly frightened old man armed with bow and arrow. $\mathrm{He}$ dashed out under the upraised spears, clasped one of the men around the knees, and implored protection. Our savages, their spears ready, glanced over their shoulders for instruction. They would have liked nothing better than to have spitted the poor old fellow.

We galloped down as fast as possible to the rescue. With reluctance our spearmen drew back, releasing their prize. We picked up his scattered bows and arrows, restored them to him, and uttered many reassurances. He was so badly frightened that he could not stand for the trembling of his knees. Undoubtedly he thought that war had broken out and that he was the first of its unconscious victims. After calming him down, we told him what we were doing, and offered to shoot him meat if he cared to accompany us. He accepted the offer with joy. So pleased, and relieved, was he that he slipped about like a young and nimble goat. His hunting companion, who all this time had stood atop a hill at a safe distance, viewed these performances with 


\section{RIDING THE PLAINS}

concern. Our captive shouted loudly for him to come join us and share in the good fortune. Not he! he knew a trap when he saw one! Not a bit disturbed by the tales this man would probably carry back home, our old fellow attached himself to us for three days!

Near sundown, to make our promise good, and also to give our own men a feast, I shot two hartebeeste near camp.

The evening was beautiful. The Machakos Range, miles distant across the valley, was mantled with thick, soft clouds. From our elevation we could see over them, and catch the glow of moonlight on their upper surfaces. We were very tired, so we turned in early and settled ourselves for a good rest.

Outside our tent the little "Injun fire" we had built for our own comfort died down to coals. A short distance away, however, was a huge bonfire around which all the savages were gathered. They squatted comfortably on their heels, roasting meat. Behind each man was planted his glittering longbladed spear. The old man held the place of honour, as befitted his flirtation with death that morning. Everybody was absolutely happy - a good fire, plenty of meat, and strangers with whom to have a grand "shauri." The clatter of tongues was a babel, for almost every one talked at once and ex- 


\section{AFRICAN CAMP FIRES}

citedly. Those who did not talk crooned weird, improvised chants in which they detailed the doings of the camp.

We fell very quickly into the half doze of too great exhaustion. It never became more than a half doze. I suppose every one who reads this has had at some time the experience of dropping asleep to the accompaniment of some noise that ought soon to cease - a conversation in the next room, singing, the barking of a dog, the playing of music, or the like. The fact that it ought soon to cease permits the falling asleep. When after an interval the subconsciousness finds the row still going on, inexcusable and unabated, it arouses the victim to staring exasperation. That was our case here. Those natives should have turned in for sleep after a reasonable amount of powwow. They did nothing of the kind. On the contrary, I dragged reluctantly back to consciousness and the realization that they had quite happily settled down to make a night of it. I glanced across the little tent to where Captain Duirs lay on his cot. He was staring straight upward, his eyes wide open.

After a few seconds he slipped out softly and silently. Our little fire had sunk to embers. A dozen sticks radiated from the centre of coals. Each made a firebrand with one end cool to the 


\section{RIDING THE PLAINS}

grasp. Captain Duirs hurled one of these at the devoted and unconscious group.

It whirled through the air and fell plunk in the other fire, scattering sparks and coals in all directions. The second was under way before the first had landed. It hit a native with ditto ditto results plus astonished and grieved language. The rest followed in rapid-magazine fire. Every one hit its mark fair and square. The air was full of sparks exploding in all directions; the brush was full of Wakamba, their blankets flapping in the breeze of their going. The convention was adjourned. There fell the sucking vacuum of a great silence. Captain Duirs, breathing righteous wrath, flopped heavily and determinedly down on his cot. I caught a faint snicker from the tent next door.

Captain Duirs sighed deeply, turned over, and prepared to sleep. Then one of the dogs uprose - I think it was Ben - stretched himself, yawned, approached deliberately, and began to drink from the canvas bathtub just outside. He drank - lap lap lap lap lap - for a very long time. It seemed incredible that any mere dog - or canvas bathtub could hold so much water. The steady repetition of this sound long after it should logically have ceased was worse than the shenzi gathering around the fire. Each lap should have been the last, but 


\section{AFRICAN CAMP FIRES}

it was not. The shenzi convention had been abated with firebrands, but the dog was strictly within his rights. The poor pups had had a long day with little water, and they could hardly be blamed for feeling a bit feverish now. At last Ben ceased. Next morning Captain Duirs claimed vehemently that he had drunk two hours forty-nine minutes and ten seconds. With a contented sigh Ben lay down. Then Ruby got up, shook herself, and yawned. A bright idea struck her. She too went over and took a drink. After that I, personally, went to sleep. But in the morning I found Captain Duirs staring-eyed and strung nearly to madness, trying feverishly to calculate how seven dogs drinking on an average of three hours apiece could have finished by morning. When Harold Hill innocently asked if he had slept well, the captain threw the remaining but now extinct firebrand at him.

One of the safari boys, a big Baganda, had twisted his foot a little, and it had swelled up considerably. In the morning he came to have it attended to. The obvious treatment was very hot water and rest; but it would never do to tell him so. The recommendation of so simple a remedy would lose me his faith. So I gave him a little dab of tick ointment wrapped in a leaf.

"This," said I, "is most wonderful medicine; but 


\section{RIDING THE PLAINS}

it is also most dangerous. If you were to rub it on your foot or your hand or any part of you, that part would drop off. But if you wash the part in very hot water continuously for a half hour, and then put on the medicine, it is good, and will cure you very soon." I am sure I do not know what they put in tick ointment; nor for the purpose did it greatly matter.

That night, also, Herbert Spencer capped the climax of his absurdities. The chops he had cooked did not quite suffice for our hunger, so we instructed him to give us some of the leg. By this we meant steak of course. Herbert Spencer was gone so long a time that finally we went to see what possibly could be the matter. We found him trying desperately to cook the whole leg in a frying pan! 


\section{XXII}

\section{THE SECOND LIONESS}

TOW our luck changed most abruptly. We 1 had been riding since early morning over the wide plains. By and by we came to a wide, shallow, flood-water course, carpeted with lava, boulders and scant, scattered brush. Two of us took one side of it, and two the other. At this we were just within hailing distance. The boys wandered down the middle.

Game was here very abundant, and in this broken country proved quite approachable. I saw one Grant's gazelle head, in especial, that greatly tempted me; but we were hunting lions, and other shooting was out of place. Also the prospects for lions had brightened, for we were continually seeing hyenas in packs of from three to six. They lay among the stones, but galloped away at our approach. The game paid not the slightest attention to these huge, skulking brutes. One passed within twenty feet of a hartebeeste; the latter hardly glanced at him. As the hyena is lazy as well as cowardly, 


\section{THE SECOND LIONESS}

and almost never does his killing, we inferred from the presence of so many a good supply of lion-killed meat. From a tributary ravine we flushed nineteen!

Harold Hill was riding with me on the right bank. His quick eye caught a glimpse of something beyond our companions on the left side. A glance through the glasses showed me that it was a lion, just disappearing over the hill. At once we turned our horses to cross. It was a mean job. We were naturally in a tremendous hurry; and the footing among those boulders and rounded rocks was so vile that a very slow trot was the best we could accomplish. And that was only by standing in our stirrups, and holding up our horses' heads by main strength. We reached the skyline in time to see a herd of game stampeding away from a depression a half mile away. We fixed our eyes on that point, and a moment later saw the lion or lioness, as it turned out, leap a little gully and make out the other side.

The footing down this slope too was appalling, consisting mainly of chunks of lava interspersed with smooth, rounded stones and sparse tufts of grass. In spite of the stones we managed a sort of stumbling gallop. Why we did not all go down in a heap, I do not know. At any rate we had no chance to 


\section{AFRICAN CAMP FIRES}

watch our quarry, for we were forced to keep our eyes strictly to our way. When finally we emerged from that tumble of rocks, she had disappeared.

Either she had galloped out over the plains, or she had doubled back to take cover in the ravine. In the latter case she would stand. Our first job, therefore, was to determine whether she had escaped over the open country. To this end we galloped our horses madly in four different directions, pushing them to the utmost, swooping here and there in wide circles. That was an exhilarating ten minutes until we had surmounted every billow of the plain, spied in all directions, and assured ourselves beyond doubt that she had not run off. The horses fairly flew, spurning the hard sod, leaping the rock dikes, skipping nimbly around the pig holes, turning like cow-ponies under pressure of knee and rein. Finally we drew up, converged, and together jogged our sweating horses back to the ravine. There we learned from the boys that nothing more had been seen of our quarry.

We dismounted, handed our mounts to their syces, and prepared to make afoot a clean sweep of the wide, shallow ravine. Here was where the dogs came in handy. We left a rear guard of two men, and slowly began our beat.

The ravine could hardly be called a ravine; rather 178 


\section{THE SECOND LIONESS}

a shallow depression with banks not over a foot high, and with a varying width of from two to twohundred feet. The grass grew very patchy, and not very high; in fact, it seemed hardly tall enough to conceal anything as large as a lioness. We men walked along the edge of this depression, while the dogs ranged back and forth in its bottom.

We had gone thus a quarter mile when one of the rear guard came running up.

"Bwana," said he, "we have seen the lioness. She is lying in a patch of grass. After you had passed, we saw her raise her head."

It seemed impossible that she should have escaped both our eyes and the dogs' noses, but we returned. The man pointed out a thin growth of dried, yellow grass ten feet in diameter. Then it seemed even more incredible. Apparently we could look right through every foot of it. The man persisted so we advanced in battle array. At thirty yards Captain Duirs saw the black tips of her ears. We all looked hard, and at last made her out, lying very flat, her head between her paws. Even then she was shadowy and unreal, and; as I have said, the cover did not look thick enough to conceal a good-sized dog.

As though she realized she had been sighted, she at this moment leaped to her feet. Instantly I 


\section{AFRICAN CAMP FIRES}

put a .405 bullet into her shoulder. Any other lion I ever saw or heard of would in such circumstances and at such a distance immediately have charged home. She turned tail and ran away. I missed her as she ran, then knocked her down with a third shot. She got up again, but was immediately hit by Captain Duir's .350 Magnum and brought to a halt. The dogs, seeing her turn tail and hearing our shots, had scrambled madly after her. We dared not shoot again for fear of hitting one of them; so we dashed rapidly into the grass and out the other side. Before we could get to her, she had sent Ruby flying through the air, and had then fallen over dead. Ruby got off lucky with only a deep gash the length of her leg.

This was the only instance I experienced of a wounded lion showing the white feather. She was, however, only about three quarters grown, and was suffering from diarrhœa. 


\section{XXIII}

\section{THE BIG LION}

$7 \mathrm{HE}$ boys skinned her while we ate lunch.

1 Then we started several of them back toward camp with the trophy, and ourselves cut across country to a small river known as the Stony Athi. There we dismounted from our horses, and sent them and the boys atop the ridge above the stream, while we ourselves explored afoot the side hill along the river.

This was a totally different sort of country from that to which we had been accustomed. Imagine a very bouldery side hill planted thickly with kneehigh blackberry vines and more sparsely with higher bushes. They were not really blackberry vines, of course, but their tripping, tangling, spiky qualities were the same. We had to force our way through these, or step from boulder to boulder. Only very rarely did we get a little rubbly clear space to walk in, and then for only ten or twenty feet. We tried in spaced intervals to cover the whole side hill. It was very hard work. The boys, 


\section{AFRICAN CAMP FIRES}

with the horses, kept pace with us on the skyline atop, and two or three hundred yards away.

We had proceeded in this fashion for about a mile, when suddenly and most unexpectedly, the biggest lion I ever saw leaped straight up from a bush twenty-five yards in front of me and with a tremendous roar vanished behind another bush. I had just time to throw up the .405 shotgun-fashion and let drive a snap shot. Clifford Hill, who was ten yards to my right, saw the fur fly, and we all heard the snarl as the bullet hit. Naturally we expected an instant charge, but, as things turned out, it was evident the lion had not seen us at all. He had leaped at the sight of our men and horses on the skyline, and when the bullet hit he must have ascribed it to them. At any rate, he began to circle through the tangled vines toward their direction.

From their elevation they could follow his movements. At once they set up howls of terror and appeals for help. Some began frantically to run back and forth. None of them tried to run away; there was nowhere to go!

The only thing that saved them was the thick and spiky character of the cover. The lion, instead of charging straight and fast, was picking an easy way. 


\section{THE BIG LION}

We tore directly up hill as fast as we were able, leaping from rock to rock and thrusting recklessly through the tangle. About halfway up I jumped to the top of a high, conical rock, and thence by good luck caught sight of the lion's great yellow head advancing steadily about eighty yards away. I took as good a sight as I could and pulled trigger. The recoil knocked me clear off the boulder, but as I fell I saw his tail go up and knew that I had hit. At once Clifford Hill and I jumped up on the rock again, but the lion had moved out of sight. By this time, however, the sound of the shots and the smell of blood had caused the dogs to close in. They did not of course attempt to attack the lion nor even to get very near him, but their snarling and barking showed us the beast's whereabout. Even this much is bad judgment on their part, as a number of them have been killed at it. The thicket burst into an unholy row.

We all manœuvred rapidly for position. Again luck was with me, for again I saw his great head, the mane standing out all around it; and for the second time I planted a heavy bullet square in his chest. This stopped his advance. He lay down; his head was up and his eyes glared, as he uttered the most reverberating and magnificent roars and growls. The dogs leaped and barked around 


\section{AFRICAN CAMP FIRES}

him. We came quite close, and I planted my fourth bullet in his shoulder. Even this was not enough. It took a fifth in the same place to finish him, and he died at last biting great chunks of earth.

The howls from the hilltop ceased. All gathered to marvel at the lion's immense size. He measured three feet nine inches at the shoulder, and nine feet eleven inches between stakes, or ten feet eleven inches along contour. This is only five inches under record. We weighed him piecemeal, after a fashion, and put him between 550 and 600 pounds.

But these are only statistics and mean little unless a real attempt is made to visualize them. As a matter of fact his mere height - that of a mediumsize zebra - was little unless accented by the impression of his tremendous power and quickness.

We skinned him, and then rode four long hours to camp. We arrived at dark, and at once set to work preparing the trophy. A dozen of us squatted around the skin, working by lantern light. Memba Sasa had had nothing to eat since before dawn, but in his pride and delight he refused to touch a mouthful until the job was finished. Several times we urged him to stop long enough for even a bite. He 


\section{THE BIG LION}

steadily declined, and whetted his knife, his eyes gleaming with delight, his lips crooning one of his weird Momumwezi songs. At eleven o'clock the task was done. Then I presented Memba Sasa with a tall mug of coffee and lots of sugar. He considered this a great honour. 


\section{XXIV \\ THE FIFTEEN LIONS}

TWO days before Captain Duirs and I were to 1 return to Juja we approached, about eleven o'clock in the morning, a long, low; rugged range of hills called Lucania. They were not very high, but bold with cliffs, buttes, and broken rocky stretches. Here we were to make our final hunt.

We led our safari up to the level of a boulder flat between two deep cañons that ran down from the hills. Here should be water, so we gathered under a lone little tree, and set about directing the simple disposition of our camp. Herbert Spencer brought us a cold lunch, and we sat down to rest and refreshment before tackling the range.

Hardly had we taken the first mouthfuls, however, when Memba Sasa, gasping for breath, came tearing up the slope from the cañon where he had descended for a drink.

"Lions!" he cried guardedly, "I went to drink, and I saw four lions. Two were lying under the 


\section{THE FIFTEEN LIONS}

shade, but two others were playing like puppies, one on its back."

While he was speaking a lioness wandered out from the cañon and up the opposite slope. She was somewhere between six and nine hundred yards away, and looked very tiny; but the binoculars brought us up to her with a jump. Through them she proved to be a good one. She was not at all hurried, but paused from time to time to yawn and look about her. After a short interval another, also a lioness, followed in her footsteps. She too had climbed well clear when a third, probably a full-grown but still immature lion, came out, and after him the fourth.

"You were right" we told Memba Sasa, "there are your four."

But while we watched a fifth, again at the spaced interval, this time a maned lion, clambered leisurely up in the wake of his family; and after him another, and another, and yet another! We gasped, and sat down the better to steady our glasses with our knees. There seemed no end to lions. They came out of that apparently inexhaustible cañon bed one at a time, and at the same regular intervals; perhaps twenty yards or so apart. It was almost as though they were being released singly. Finally we had fifteen in sight. 


\section{AFRICAN CAMP FIRES}

It was a most magnificent spectacle, and we could enjoy it unhurried by the feeling that we were losing opportunities. At that range it would be silly to open fire. If we had descended to the cañon in order to follow them out the other side, they would merely have trotted away. Our only chance was to wait until they had disappeared from sight, and then to attempt a wide circle in order to catch them from the flank. In the meantime we had merely to sit still.

Therefore we stared through our glasses and enjoyed to the full this most unusual sight. There were four cubs about as big as setter dogs; four fullgrown but immature youngsters; four lionesses, and three male lions. They kept their spaced, single file formation for two thirds the ascent of the hill probably the nature of the ground forced them to it - and then gradually drew together. Near the top, but still below the summit, they entered a jumble of boulders and stopped. We could make out several of them lying down. One fine old yellow fellow stretched himself comfortably atop a flat rock, in the position of a bronze lion on a pedestal.

We waited twenty minutes to make sure they were not going to move. Then, leaving all our men except the gunbearers under the tree, we slipped back until out of sight, and began to execute our 


\section{THE FIFTEEN LIONS}

flank movement. The chances seemed good. The jumble of boulders was surrounded by open country, and it was improbable the lions could leave it without being seen. We had arranged with our men a system of signals.

For two hours we walked very hard in order to circle out of sight, down wind, and to gain the other side of the ridge back of the lions. We purposed slipping over the ridge and attacking from above. Even this was but a slight advantage. The job was a stiff one, for we might expect certainly the majority to charge.

Therefore when we finally deployed in skirmish order and bore down on that patch of brush and boulders, we were braced for the shock of battle. We found nothing. Our men, however, signalled that the lions had not left cover. After a little search, however, we discovered a very shallow depression running slantwise up the hill and back of the cover. So slight it was that even the glasses had failed to show it from below. The lions had in all probability known about us from the start, and were all the time engaged in withdrawing after their leisurely fashion.

Of course we hunted for them; in fact we spent two days at it; but we never found trace of them again. The country was too hard for tracking. They 


\section{AFRICAN CAMP FIRES}

had left Lucania. Probably by the time we had completed our two hours of flanking movement they were five miles away. The presence of cubs would account for this. In ordinary circumstances we should have had a wonderful and exciting fight. But the sight of those fifteen great beasts was one I shall never forget.

After we had hunted Lucania thoroughly, we parted company with the Hills, and returned to Juja Farm. 


\section{PART V}

\section{THE TSAVO RIVER}





\section{XXV}

\section{VOI}

DART way up the narrow-gauge railroad from 1 the coast is a station called Voi. On his way to the interior the traveller stops there for an evening meal. It is served in a high, wide stone room by white-robed Swahilis under command of a very efficient and quiet East Indian. The voyager steps out into the darkness to look across the way upon the outlines of two great rounded hills against an amethyst sky. That is all he ever sees of Voi, for on the down trip he passes through it about two o'clock in the morning.

At that particularly trying hour F. and I descended and attempted, by the light of lanterns, to sort out twenty safari boys strange to us, and miscellaneous camp stores. We did not entirely succeed. Three men were carried on down the line; and the fly to our tent was never seen again.

The train disappeared. Our boys, shivering, crept into corners. We took possession of the dak-bungalow maintained by the railroad for just 


\section{AFRICAN CAMP FIRES}

such travellers as ourselves. It was simply a high stone room, with three iron beds, and a corner so cemented that one could pour pails of water over one's self without wetting down the whole place. The beds were supplied with mosquito canopies, and strong wire springs. Over these we spread our own bedding, and thankfully resumed our slumbers.

The morning discovered to us Voi as the station, the district commissioner's house on a distant side hill, and a fairly extensive East Indian bazaar. The keepers of the latter traded with the natives. Immediately about the station grew some flat shady trees. All else was dense thorn scrub pressing close about the town. Over opposite were the tall, rounded mountains.

Nevertheless, in spite of its appearance, Voi has its importance in the scheme of things. From it, crossing the great Serengetti desert, runs the track to Kilimanjaro and that part of German East Africa. The Germans have as yet no railroad; so they must perforce patronize the British line this far, and then trek across. As the Kilimanjaro district is one rich in natives and trade, the track is well used. Most of the transport is done by donkeys - either in carts or under the pack saddle. As the distance from water to water is very great, the journey is a hard one. This fact, and the incidental consideration that 


\section{VOI}

from fly and hardship the mortality in donkeys is very heavy, pushes the freight rates away up. And that fact accounts for the motor car, which has been my point of aim from the beginning of this paragraph.

The motor car plies between Voi and the German line, at exorbitant rates. Our plan was to have it take us and some galvanized water tanks out into the middle of the desert and dump us down there. So after breakfast we hunted up the owner.

He proved to be a very short, thick-set, blond German youth who justified Weber and Fields. In fact, he talked so exactly like those comedians that my task in visualizing him to you is somewhat lightened. If all, instead of merely a majority, of my readers had seen Weber and Fields, that task would vanish.

We explained our plan, and asked him his price.

"Sefen hundert and feefty rupees,"* said he uncompromisingly.

He was abrupt, blunt, and insulting. As we wanted transportation very much - though not seven hundred and fifty rupees' worth - we persisted. He offered an imperturbable take-it-orleave-it stolidity. The motor truck stood near. I said something technical about the engine; then

${ }^{*} \$ 250$. 


\section{AFRICAN CAMP FIRES}

something more. He answered these remarks, though grudgingly. I suggested that it took a mighty good driver to motor through this rough country. He mentioned a particular hill. I proposed that we try the station restaurant for beer while he told me about it. He grunted, but headed for the station.

For two hours we listened to the most blatant boasting. He was a great driver; he had driven for M., the American millionaire; for the Chinese Ambassador to France; for Grand-duke Alexis; for the Kaiser himself! We learned how he had been the trusted familiar of these celebrities, how on various occasions - all detailed at length - he had been treated by them as an equal; and he told us sundry sly, slanderous, and disgusting anecdotes of these worthies, his forefinger laid one side his nose. When we finally got him worked up to the point of going to get some excessively bad photographs "I haf daken myself!" we began to have hopes. So we tentatively approached once more the subject of transportation.

Then the basis of the trouble came out. One Davis, M. P. from England, had also dealt with our friend. Davis, as we reconstructed him, was of the blunt type, with probably very little feeling of democracy for those in subordinate positions, and 


\section{VOI}

with most certainly a good deal of insular and racial prejudice. Evidently a rather vague bargain had been struck, and the motor had set forth. 'Then ensued financial wranglings and disputes as to terms. It ended by useless hauteur on Davis's part, and inexcusable but effective action by the German. For Davis found himself dumped down on the Serengetti desert and left there.

We heard all this in excruciatingly funny Weberandfieldese, many times repeated. The German literally beat his breast and cried aloud against Davis. We unblushingly sacrificed a probably perfectly worthy Davis to present need, and cried out against him too.

"Am I like one dog?" demanded the German fervently.

"Certainly not!" we cried with equal fervour. We both like dogs.

Then followed wearisomely reiterated assurance that we, at least, knew how a gentleman should be treated, and more boasting of proud connection in the past. But the end of it was a bargain of reasonable dimensions for ourselves, our personal boys, and our loads. Under plea of starting our safari boys off we left him, and crept, with shattered nerves, around the corner of the dak-bungalow. There we lurked, busy at pretended affairs, until our friend 


\section{AFRICAN CAMP FIRES}

swaggered away to the Hindu quarters, where, it seems, he kept his residence.

About ten o'clock a small safari marched in afoot. It had travelled all of two nights across the Thirst, and was glad to get there. The single white man in charge had been three years alone among the natives near Kilimanjaro, and he was now out for a six months' vacation at home. 'Two natives in the uniform of Soudanese troops hovered near him very sorrowful. He splashed into the water of the dak-bungalow, and then introduced himself. We sat in teakwood easy chairs and talked all day. He was a most interesting, likable and cordial man, at any stage of the game. The game, by means of French vermouth - of all drinks!- progressed steadily. We could hardly blame him for celebrating. By afternoon he wanted to give things away. So insistent was he that F. finally accepted an ebony walking staff, and I an ebony knife inset with ivory. If we had been the least bit unscrupulous, I am afraid the relatives at home would have missed their African souvenirs. He went out via freight car, all by himself, seated regally in a steamer chair between both wide-open side doors, one sorrowful native squatted on either side to see that he did not lurch out into the landscape. 


\section{XXVI \\ THE FRINGE-EARED ORYX}

A $\mathrm{T}$ ten o'clock the following morning we started. 1 On the high front seat, under an awning, sat the German, F., and I. The body of the truck was filled with safari loads, Memba Sasa, Simba, Mohamet, and F.'s boy, whose name I have forgotten. The arrangement on the front seat was due to a strike on the part of $\mathrm{F}$.

"Look here," said he to me, "you've got to sit next that rotter. We want him to bring us back some water from the other side; and I'd break his neck in ten minutes. You sit next him and give him your motor car patter."

Therefore I took the middle seat and played chorus. The road was not a bad one, as natural mountain roads go; I have myself driven worse in California. Our man, however, liked to exaggerate all the difficulties, and while doing it to point to himself with pride as a perfect wonder. Between times he talked elementary mechanics.

"The inflammation of the sparkling plugs" was 


\section{AFRICAN CAMP FIRES}

one of his expressions that did much to compensate.

The country mounted steadily through the densest thorn scrub I have ever seen. It was about fifteen feet high, and so thick that its penetration save by made tracks would have been an absolute impossibility. Our road ran like a lane between two spiky jungles. Bold bright mountains cropped up, singly and in short ranges, as far as the eye could see them.

This sort of thing for twenty miles - more than a hard day's journey on safari. We made it in a little less than two hours; and the breeze of our going kept us reasonably cool under our awning. We began to appreciate the real value of our diplomacy.

At noon we came upon a series of unexpectedly green and clear small hills just under the frown of a sheer rock cliff. This oasis in the thorn was occupied by a few scattered native huts and the usual squalid Indian dukka, or trading store. At this last our German friend stopped. From under the of seat he drew out a collapsible table and a basket of provisions. These we were invited to share. Diplomacy's highest triumph!

After lunch we surmounted our first steep grade to the top of a ridge. This we found to be the beginning of a long elevated plateau sweeping gently 


\section{THE FRINGE-EARED ORYX}

downward to a distant heat mist which later experience proved a concealment to snow-capped Kilimanjaro. The plateau also looked to be covered with scrub. As we penetrated it, however, we found the bushes were more or less scattered, while in the wide, shallow dips between the undulations were open, grassy meadows. There was no water. Isolated mountains or peaked hills showed here and there in the illimitable spaces, some of them fairly hull down, all of them toilsomely distant. This was the Serengetti itself.

In this great extent of country somewhere were game herds. They were exceedingly migratory, and nobody knew very much about them. One of the species would be the rare and localized fringe-eared oryx. This beast was the principal zoölogical end of our expedition; though, of course, as always, we hoped for a chance lion. Geographically we wished to find the source of the Swanee River, and to follow that stream down to its joining with the Tsavo.

About half-past one we passed our safari boys. We had intended to stop and replenish their canteens from our water drums; but they told us they had encountered a stray and astonishing shower, and did not need more. We left them trudging cheerfully across the desert. They had travelled most of the night before, would do the same in the night to 


\section{AFRICAN CAMP FIRES}

come, and should reach our camping place about noon of the next day.

We ourselves stopped about four o'clock. In a few hours we had come a hard three days' march. Over the side went our goods. We bade the German a very affectionate farewell; for he was still to fill our drums from one of the streams out of Kilimanjaro and deliver them to us on his return trip next day. We then all turned to and made camp. The scrub desert here was exactly like the scrub desert for the last sixty miles.

The next morning we were up and off before sunrise. In this job, time was a very large element of the contract. We must find our fringe-eared oryx before our water supply gave out. Therefore we had resolved not to lose a moment.

The sunrise was most remarkable-lacework, flat clouds, with burnished copper-coloured clouds behind glowing through the lace. We admired it for some few moments. Then one of us happened to look higher. There, above the sky of the horizon, apparently suspended in midair halfway to the zenith, hung like delicate bubbles the double snowclad peaks of Kilimanjaro. Between them and the earth we could apparently see clear sky. It was in reality, of course, the blue heat haze that rarely leaves these torrid plains. I have seen many moun- 


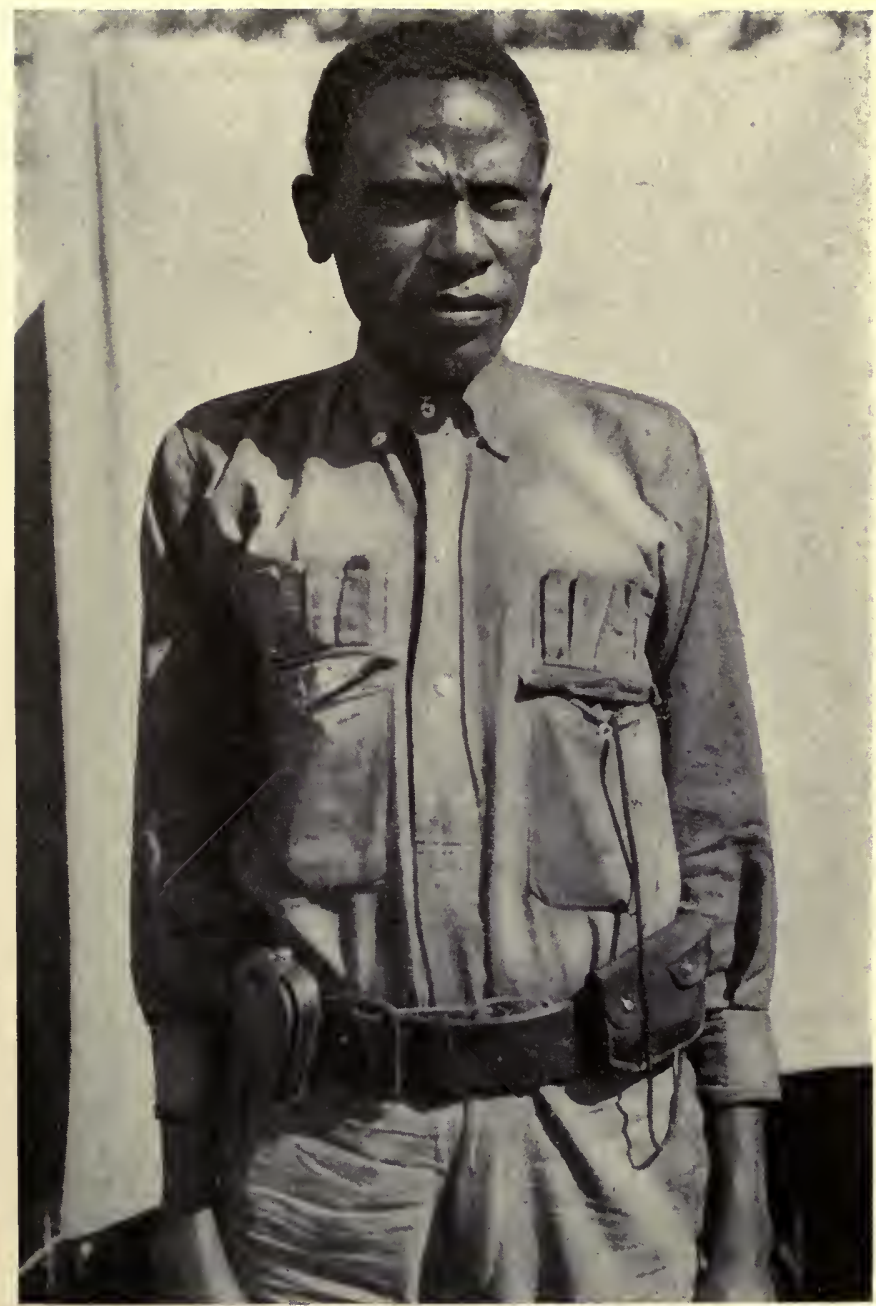

"Kongoni" 


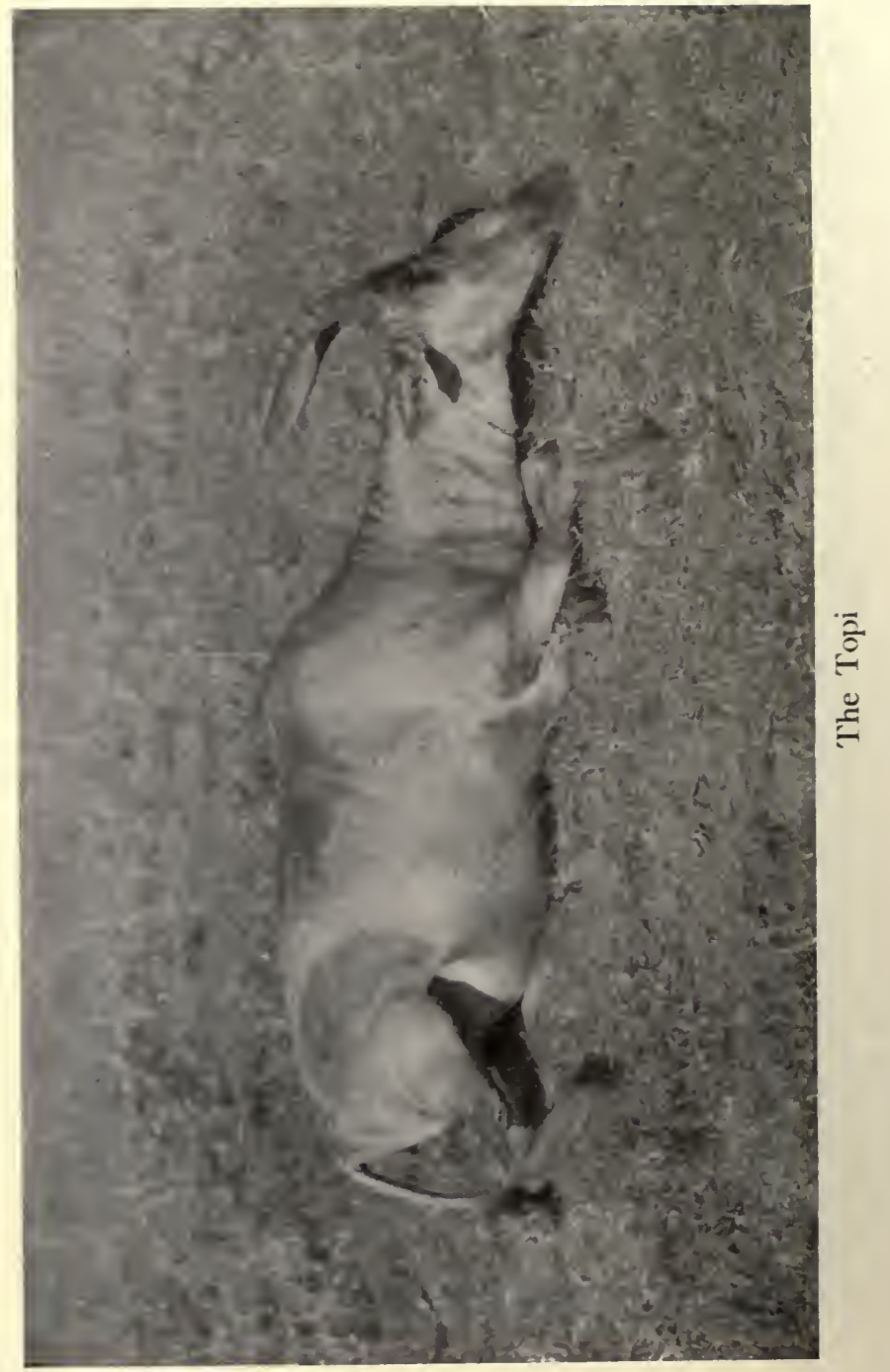




\section{THE FRINGE-EARED ORYX}

tains in all parts of the world, but none as fantastically insubstantial, as wonderfully lofty, as gracefully able to yield before clouds and storms and sunrise glows all the space in infinity they.could possibly use, and yet to tower above them all serene in an upper space of its own. Nearly every morning of our journey to come we enjoyed this wonderful vision for an hour or so. Then the mists closed in. The rest of the day showed us a grayish sky along the western horizon, with apparently nothing behind it.

In the meantime we were tramping steadily ahead over the desert, threading the thorn scrub, crossing the wide shallow grass-grown swales, spying about us for signs of game. At the end of three or four miles we came across some ostrich and four hartebeeste. This encouraged us to think we might find other game soon; for the hartebeeste is a gregarious animal.

Suddenly we saw a medium-sized squat beast that none of us recognized, trundling along like a badger, sixty yards ahead. Any creature not easily identified is a scientific possibility in Africa. Therefore we fired at once. One of the bullets hit his forepaw. Immediately this astonishing small creature turned and charged us! If his size had equalled his ferocity, he would have been a formidable opponent. 


\section{AFRICAN CAMP FIRES}

We had a lively few minutes. He rushed us again and again, uttering ferocious growls. We had to step high and lively to keep out of his way. Between charges he sat down and tore savagely at his wounded paw. We wanted him as nearly perfect a specimen as possible, so tried to rap him over the head with a club. Owing to remarkably long teeth and claws, this was soon proved impracticable; so we shot him. He weighed about thirty pounds; and we subsequently learned that he was a honey badger, an animal very rarely captured.

We left the boys to take the whole skin and skull of this beast, and strolled forward slowly. The brush ended abruptly in a wide valley. It had been burnt over, and the new grass was coming up green. We gave one look, and sank back into cover.

The sparse game of the immediate vicinity had gathered to this fresh feed. A herd of hartebeeste and gazelle were grazing; and five giraffe adorned the skyline. But what interested us especially was a group of about fifty cob-built animals with the unmistakable rapier horns of the oryx. We recognized them as the rarity we desired.

The conditions were most unfavourable. The cover nearest them gave a range of three hundred yards; and even this would bring them directly between us and the rising sun. There was no help 


\section{THE FRINGE-EARED ORYX}

for it, however. We made our way to the bushes nearest the herd; and I tried to align the blurs that represented my sights. At the shot, ineffective, they raced to the right across our front. We laid low. As they had seen nothing they wheeled and stopped after two hundred yards of flight. This shift had brought the light into better position. Once more I could define my sights. From the sitting position I took careful aim at the largest buck. He staggered twenty feet and fell dead. The distance was just 38I paces. This lucky shot was indeed fortunate, for we saw no more fringeeared oryx. 


\section{XXVII}

\section{ACROSS THE SERENGETTI}

W ${ }^{E}$ arrived in camp about noon, almost exhausted with the fierce heat and a six hours' tramp, to find our German friend awaiting us, By an irony of fate the drums of water he had brought back with him were now unnecessary; we had our oryx. However, we wearily fed him lunch and listened to his prattle and finally sped him on his way, hoping never to see him again.

About three o'clock our men came in. We doled out water rations, and told them to rest in preparation for the morrow.

Late that night we were awakened by a creaking and snorting and the flash of torches passing. We looked out to see a donkey transport toiling slowly along, travelling thus at night to avoid the terrific day heats. The two-wheeled carts with their wild and savage drivers looked very picturesque in the flickering lights. We envied them vaguely their defined route that permitted night travel, and sank to sleep. 


\section{ACROSS THE SERENGETTI}

In the morning, however, we found they had left with us new responsibilities in the shape of an elderly Somali, very sick, and down with the fever. This was indeed a responsibility. It was manifestly impossible for us to remain there with him; we should all die of thirst. It was equally impossible to take him with us, for he was quite unfit to travel under the sun. Finally, as the best solution of a bad business, we left him five gallons of water, some food, and some quinine, together with the advice to rest until night, and then to follow his companions along the beaten track. What between illness and wild beasts his chances did not look very good, but it was the best we could do for him. This incident exemplifies well the cruelty of this singular people. They probably abandoned the old man because his groans annoyed them, or because one of them wanted to ride in his place on the donkey cart.*

We struck off as early as possible through the thorn scrub on a compass bearing that we hoped would bring us to a reported swamp at the head of the Swanee River. The Swanee River is one of the sources of the Tsavo. Of course this was guesswork. We did not know certainly the location of the swamp, its distance from us, nor what lay be-

\footnotetext{
*I have just heard that this old man survived, and has been singing our praises in Nairobi as the saviours of his life.
} 


\section{AFRICAN CAMP FIRES}

tween us and it. However, we loaded all our transportable vessels with water, and set forth.

The scrub was all alike; sometimes thinner, sometimes thicker. We marched by compass until we had raised a conical hill above the horizon, and then we bore just to the left of that. The surface of the ground was cut by thousands of game tracks. They were all very old, however, made after a rain; and it was evident the game herds venture into this country only when it contains rainwater. After two hours, however, we did see one solitary hartebeeste, whom we greeted as an old friend in desolation. Shortly afterward we ran across one oribi, which I shot for our own table.

At the end of two hours we sat down. The safari of twenty men was a very miscellaneous lot, consisting of the rag-tag and bobtail of the bazaars picked up in a hurry. They were soft and weak, and they straggled badly. The last weakling prodded along by one of our two askaris - limped in only at the end of half an hour. Then we took a new start.

The sun was by now up and hot. The work was difficult enough at best, but the weight of the tropics was now cast in the scale. Twice more within the next two hours we stopped to let every one catch up. Each time this required a longer interval. In 


\section{ACROSS THE SERENGETTI}

the thorn it was absolutely essential to keep in touch with every member of the party. A man once lost would likely remain so, for we could not afford to endanger all for the sake of one.

Time wore on until noon. Had it not been for a thin film of haze that now overspread the sky, I think the sun would have proved too much for some of the men. Four or five straggled so very badly that we finally left them in charge of one of our two askaris, with instructions to follow on as fast as they could. In order to make this possible, we were at pains to leave a well-marked trail.

After this fashion, slowly, and with growing anxiety for some of the men, we drew up on our landmark hill. There our difficulties increased; the thorn brush thickened. Only by a series of short zigzags and by taking advantage of every rhino trail going in our direction could we make our way through it at all; while to men carrying burdens on their heads the tangle aloft must have been fairly maddening. So slow did our progress necessarily become, and so difficult was it to keep in touch with everybody, that F. and I finally halted for consultation. It was decided that I should push on ahead with Memba Sasa to make certain that we were not on the wrong line, while $F$. and the askaris struggled with the safari. 


\section{AFRICAN CAMP FIRES}

Therefore I took my compass bearing afresh, and plunged into the scrub. The sensation was of hitting solid ground after a long walk through sand. We seemed fairly to shoot ahead and out of sight. Whenever we came upon earth we marked it deeply with our heels; we broke twigs downward, and laid hastily snatched bunches of grass to help the trail we were leaving for the others to follow. This, in spite of our compass, was a very devious track. Beside the thorn bushes were patches of spiky aloe, coming into red flower, and the spears of sisal.

After an hour's steady, swift walking the general trend of the country began to slope downward. This augured a watercourse between us and the hills around Kilimanjaro. There could be no doubt that we would cut it; the only question was whether it, like so many desert watercourses, might not prove empty. We pushed on the more rapidly. Then we caught a glimpse, through a chance opening, of the tops of trees below us. After another hour we suddenly burst from the scrub to a strip of green grass beyond which were the great trees, the palms, and the festooned vines of a watercourse. Two bush bucks plunged into the thicket as we approached; and fifteen or twenty mongooses sat up as straight and stiff as so many picket pins the better to see us.

For a moment my heart sank. The low under- 


\section{ACROSS THE SERENGETTI}

growth beneath the trees apparently swept unbroken from where we stood to the low bank opposite. It was exactly like the shallow damp but waterless ravines at home, filled with blackberry vines. We pushed forward, however, and found ourselves looking down on a smooth, swift-flowing stream.

It was not over six feet wide, grown close with vines and grasses, but so very deep and swift and quiet that an extraordinary volume of water passed, as through an artificial aqueduct. Furthermore, unlike most African streams, it was crystal clear. We plunged our faces and wrists in it, and took long, thankful draughts. It was all most grateful after the scorching desert. The fresh trees meeting in canopy overhead were full of monkeys and bright birds; festooned vines swung their great ropes here and there; long heavy grass carpeted underfoot.

After we had rested a few minutes we filled our empty canteens, and prepared to start back for our companions. But while I stood there, Memba Sasa, good faithful Memba Sasa, seized both canteens and darted away.

"Lie down!" he shouted back at me, "I will go back."

Without protest - which would have been futile anyway - I sank down on the grass. I was very tired. A little breeze followed the watercourse; the 


\section{AFRICAN CAMP FIRES}

grass was soft; I would have given anything for a nap. But in wild Africa a nap is not healthy; so I drowsily watched the mongooses that had again come out of seclusion, and the monkeys, and the birds. At the end of a long time, and close to sundown, I heard voices. A moment later F., Memba Sasa, and about three quarters of the men came in. We all, white and black, set to work to make camp. Then we built smudges and fired guns in the faint hope of guiding in the stragglers. As a matter of fact we had not the slightest faith in these expedients. Unless the men were hopelessly lost they should be able to follow our trail. They might be almost anywhere out in that awful scrub. The only course open to them would be to climb thorn trees for the night. Next day we would organize a formal search for them.

In the meantime, almost dead from exhaustion, we sprawled about everywhere. The men, too dispirited even to start their own campfires, sat around resting as do boxers between rounds. Then to us came Memba Sasa, who had already that day made a double journey, and who should have been the most tired of all.

"Bwana," said he, "if you will lend me Winchi,* and a lantern, I will bring in the men."

*His name for the .405 Winchester. 


\section{ACROSS THE SERENGETTI}

We lent him his requirements, and he departed. Hours later he returned, carefully leaned "Winchi" in the corner of the tent, deposited the lantern, and stood erect at attention.

"Well, Memba Sasa?" I inquired.

"The men are here."

"They were far?"

"Very far."

"Vema, Memba Sasa, assanti sana."*

That was his sole - and sufficient reward.

*Very good, Memba Sasa, thanks very much. 


\section{XXVIII}

\section{DOWN THE RIVER}

R ELIEVED now of all anxiety as to water we 1 had merely to make our way downstream. First, however, there remained the interesting task of determining its source.

Accordingly, next day we and our gunbearers left the boys to a well-earned rest, and set out upstream. At first we followed the edge of the river jungle, tramping over hard hot earth, winding in and out growths of thorn scrub and brilliant aloes. We saw a herd of impallas gliding like phantoms, and as we stood in need of meat, I shot at one of them but missed. The air was very hot and moist. At five o'clock in the morning the thermometer had stood at 78 ; and by noon it had mounted to I06. In addition the atmosphere was filled with the humidity that later in the day was to break in extraordinary deluges. We moved slowly, but even then our garments were literally dripping wet.

At the end of three miles the stream bed widened. We came upon beautiful, spacious, open lawns of 


\section{DOWN THE RIVER}

from eighty to one hundred acres apiece, separated from each other by narrow strips of tall forest trees. The grass was high, and waved in the breeze like planted grain; the boundary trees resembled artificial windbreaks of eucalyptus or Normandy poplar. One might expect a white ranch house beyond some low clump of trees, and chicken runs, and corrals.

Along these apparent boundaries of forest trees our stream divided, and divided again; so that we were actually looking upon what we had come to seek: the source of the Swanee branch of the Tsavo River. In these peaceful, protected meadows was it cradled. From them it sprang full size out into the African wilderness.

A fine impalla buck grazed in one of these fields. I crept as near him as I could behind one of the windbreak rows of trees. It was not very near, and for the second time I missed. Thereupon we decided two things: that we were not really meat hungry, and that yesterday's hard work was not conducive to to-day's good shooting.

Having thus accomplished the second object of our expedition, we returned to camp. From that time begins a regular sequence of events on which I look back with the keenest of pleasure. The two constant factors were the river and the great dry country on either side. Day after day we followed 


\section{AFRICAN CAMP FIRES}

down the one, and we made brief excursions out into the other. Each night we camped near the sound of the swift-running, water; where the winds rustled in the palms; the acacias made lacework across the skies; and the jungle crouched in velvet blackness close to earth, like a beast.

Our life in its routine was regular; in its details bizarre and full of the unexpected. Every morning we arose an hour before day, and ate by lantern light and the gleam of fires. At the first gray we were afoot and on the march. F. and I, with our gunbearers, then pushed ahead down the river, leaving the men to come along as fast or as slowly as they pleased. After about six hours or so of marching, we picked out a good camp site, and lay down to await the safari. By two o'clock camp was made. Also it was very hot. After a light lunch we stripped to the skin, lay on our cots underneath the mosquito canopies, and tried to doze or read. The heat at this time of day was blighting. About four o'clock, if we happened to be inspired by energy, one or the other of us strolled out at right angles to the stream to see what we could see. The evening was tepid and beautiful. Bathed and pajama-clad we lolled in our canvas chairs, smoking, chatting, or listening to the innumerable voices of the night. 


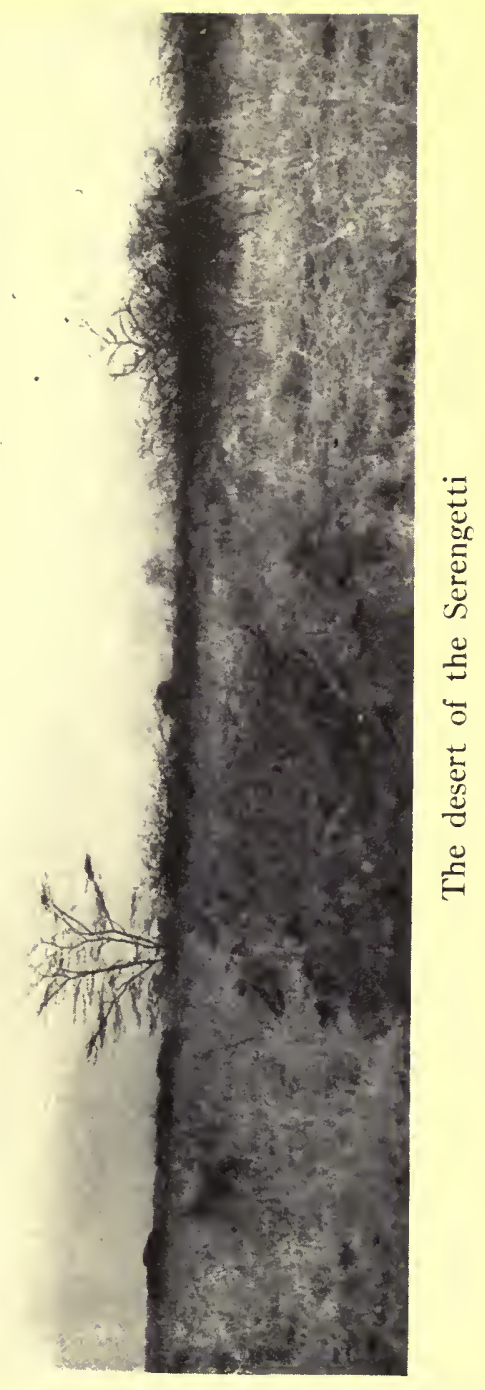



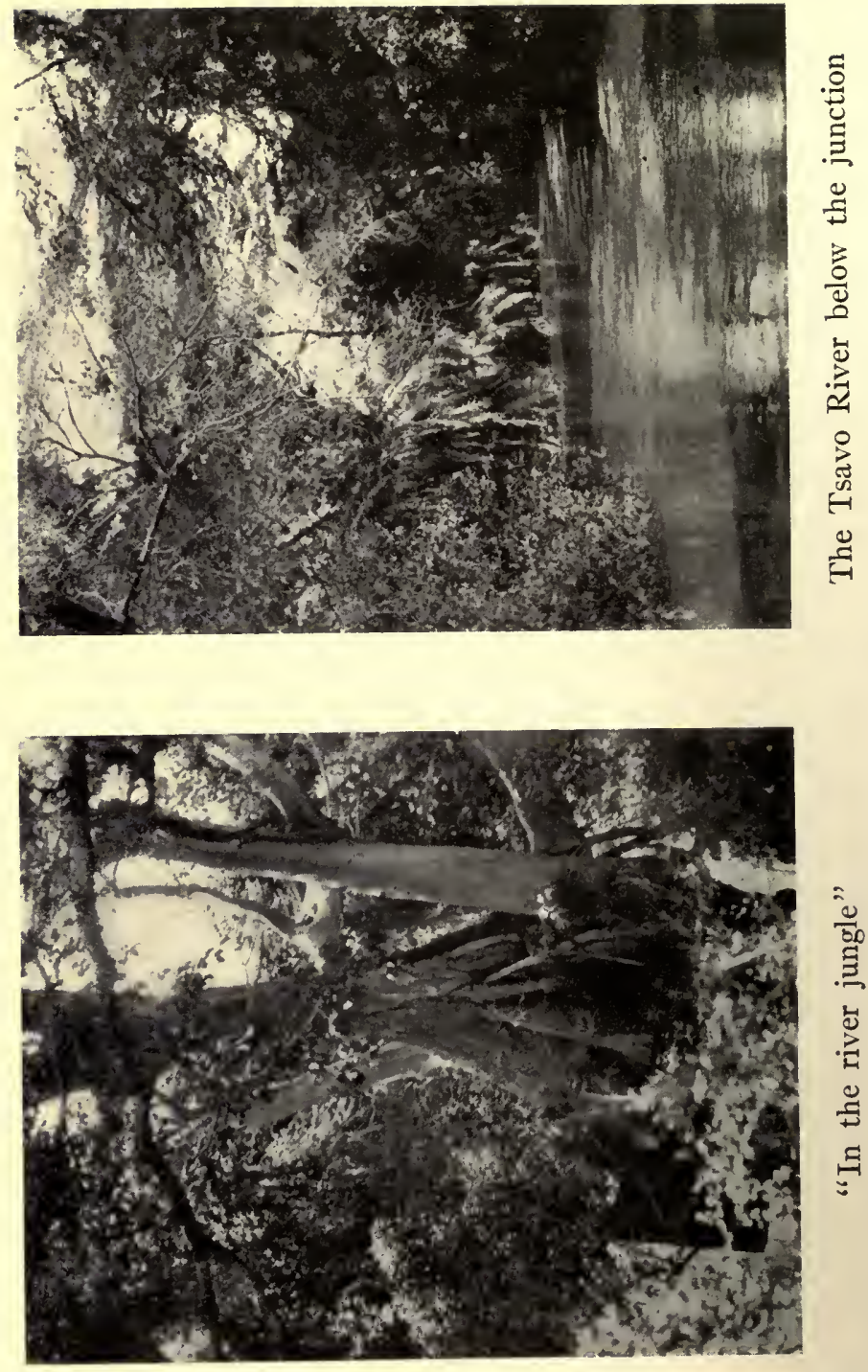


\section{DOWN THE RIVER}

Such was the simple and almost invariable routine of our days. But enriching it, varying it, disguising it even - as rain-squalls, sunshine, cloud shadow, and unexpected winds modify the landscape so well known from a study window - were the incredible incidents and petty adventure of African travel.

The topography of the river itself might be divided very roughly into three: the headwater country down to its junction with the Tsavo, the palm-elephantgrass stretch, and the gorge and hill district just before it crosses the railroad.

The headwater country is most beautiful. The stream is not over ten feet wide, but very deep, swift, and clear. It flows between defined banks, and is set in a narrow strip of jungle. In places the bed widens out to a carpet of the greenest green grass sown with flowers; at other places it offers either mysterious thickets, spacious cathedrals, or snug bowers. Immediately beyond the edge of this river jungle begins the thorn scrub, more or less dense. Distant single mountains or buttes serve as landmarks in a brush-grown, gently rising, strongly rolling country Occasional alluvial flats draw back to low cliffs not over twenty feet high.

After the junction of the Tsavo palms of various sorts replace to a large extent the forest trees. Naturally also the stream widens and flows more 


\section{AFRICAN CAMP FIRES}

slowly. Outside the palms grow tall elephant grass and bush. Our marching had generally to be done in the narrow, neutral space between these two growths. It was pleasant enough, with the river snatching at the trailing branches, and the birds and animals rustling away. Beyond the elephant-grass flats low ridges ran down to the river, varying in width, but carrying always with them the dense thorn. Between them ran recesses, sometimes three or four hundred acres in extent, high with elephant grass or little trees like popples. So much for the immediate prospect on our right as we marched. Across the river to our left were huge riven mountains, with great cliffs and cañons. As we followed necessarily every twist and turn of the river, sometimes these mountains were directly ahead of us, then magically behind, so that we thought we had passed them by. But the next hour threw them again across our trail. The ideal path would, of course, have cut across all the bends and ridges; but the thorn of the ridges, and the elephant grass of the flats forbade it. So we marched ten miles to gain four.

After days of struggle and deception we passed those mountains. Then we entered a new type of country where the Tsavo ran in cañons between hills. The high cliffs often towered far above us; 


\section{DOWN THE RIVER}

we had to pick our way along narrow river ledges; again the river ran like a trout stream over riffles and rapids, while we sauntered along cleared banks beneath the trees. Had we not been making a forced march under terrific heat at just that time, this last phase of the river might have been the pleasantest of all.

Throughout the whole course of our journey the rhinoceros was the most abundant of the larger animals. The indications of old tracks proved that at some time of the year, or under some different conditions, great herds of the more gregarious plains antelope and zebra visited the river, but at the time of our visit they lacked. Rhinoceros, however, in incredible numbers came regularly to water. Paradoxically, we saw very few of them; and enjoyed comparative immunity from their charges. This was due to the fact that their habits and ours swung in different orbits. The rhinoceros, after drinking took to the hot, dry thorn scrub in the low hills; and as he drank at night, we rarely. encountered him in the river bottoms where we were marching. This was very lucky, for the cover was so dense that a meeting must necessarily be at close quarters. Indeed these large and truculent beasts were rather a help than a hindrance, for we often made use of their wide, clear paths to penetrate some particularly 


\section{AFRICAN CAMP FIRES}

distressing jungle. However, we had several small adventures with them; just enough to keep us alert in rounding corners, or approaching bushes - and nine tenths of our travel was bushes and corners. The big flat footsteps, absolutely fresh in the dust, padded methodically ahead of us down the only way until it seemed that we could not fail to plump upon their maker around the next bend. We crept forward foot by foot, every sense alert, finger on trigger. Then after a time the spoor turned off to the right, toward the hills. We straightened our backs and breathed a sigh of relief. This happened over and over again.

At certain times of year also elephants frequent the banks of the Tsavo in considerable numbers. We saw many old signs; and once came upon the fresh path of a small herd. The great beasts had passed by that very morning. We gazed with considerable awe on limbs snatched bodily from trees; on flat-topped acacias a foot in diameter pulled up by the roots and stood upside down; on tree trunks twisted like ropes.

Of the game by far the most abundant were the beautiful red impalla. We caught glimpses of their graceful bodies gliding in and out of sight through the bushes; or came upon them standing in small openings, their delicate ears pointed to us. They and the tiny dik-dik furnished our table; and an occasional waterbuck satisfied the men. One day 


\section{DOWN THE RIVER}

we came on one of the latter beasts sound asleep in a tiny open space. He was lying down, and his nose rested against the earth, just like a very old family horse in a paddock.

Beside these common species were bush buck, warthog, lesser kudu, giraffe, and leopard. The bush buck we jumped occasionally quite near at hand. They ducked their heads low and rushed tearingly to the next cover. The leopard we heard sighing every night, and saw their pad marks next day; but only twice did we catch glimpses of them. One morning we came upon the fresh killed carcass of a female lesser kudu from which, evidently, we had driven the slayer.

These few species practically completed the game list. They were sufficient for our needs; and the lesser kudu was a prize much desired for our collection. But by far the most interesting to me were the smaller animals, the birds, and the strange, innumerable insects.

We saw no natives in the whole course of our journey.

The valley of the river harboured many monkeys. They seemed to be of two species, blue and brown, but were equally noisy and amusing. They retired ahead of our advance with many remarks, or slipped past us to the rear without any comments whatever. When we made camp they retired with indignant 


\section{AFRICAN CAMP FIRES}

protests, and when we had quite settled down, they returned as near as they dared.

One very hot afternoon I lay on my canvas cot in the open staring straight upward into the overarching greenery of the trees. This is a very pleasant thing to do. The beautiful upspreading, outreaching of the tree branches and twigs intrigue the eye; the leaves make fascinating hypnotically waving patterns against a very blue sky; and in the chambers and galleries of the upper world the birds and insects carry on varied businesses of their own. After a time the corner of my eye caught a quick movement far to the left and in a shadow. At once I turned my attention that way. After minute scrutiny I at length made out a monkey. Evidently considering himself quite unobserved, he was slowly and with great care stalking our camp. Inch by inch he moved, taking skilful advantage of every bit of cover, flattening himself along the limbs, hunching himself up behind bunches of leaves, until he had gained a big limb directly overhead. There he stretched flat, staring down at the scene that had so strongly aroused his curiosity. I lay there for over two hours reading and dozing. My friend aloft never stirred. When dusk fell he was still there. Some time after dark he must have regained his band, for in the morning the limb was vacant. 


\section{DOWN THE RIVER}

Now comes the part of this story that really needs a witness, not to veracity perhaps, but to accuracy of observations. Fortunately I have F. About noon next day the monkey returned to his point of observation. He used the same precautions as to concealment; he followed his route of the day before; he proceeded directly to his old conning tower on the big limb. It did not take him quite so long to get there, for he had already scouted out the trail. And close at his heels followed two other monkeys! They crawled where he crawled; they scrooched where he scrooched; they hid where he hid; they flattened themselves out by him on the big limb and all three of them passed the afternoon gazing down on the strange and fascinating things below. Whether these newcomers were part of the first one's family out for a treat, or whether they were Cook's Tourists of the Jungle in charge of my friend's competence as a guide, I do not know.

Farther down the river F. and I stopped for some time to watch the crossing of forty-odd of the little blue monkeys. The whole band clambered to near the top of a tall tree growing by the water's edge. There, one by one, they ran out on a straight overhanging limb and cast themselves into space. On the opposite bank of the river, and leaning well out, grew a small springy bush. Each monkey 


\section{AFRICAN CAMP FIRES}

landed smash in the middle of this; clasped it with all four hands; swayed alarmingly; recovered and scampered ashore. It was rather a nice problem in ballistics, this; for the mistake in calculation of a foot in distance or a pound in push would land Mr. Monkey in the water. And the joke of it was that directly beneath that bush lay two hungrylooking crocodiles! As each tiny body hurtled through the air I'll swear a look of hope came into the eyes of those crocs. We watched until the last had made his leap. There were no mistakes. The joke was on the crocodiles.

We encountered quite a number of dog-faced baboons. These big apes always retreated very slowly and noisily. Scouts in the rear guard were continually ascending small trees or bushes for a better look at us, then leaping down to make disparaging remarks. One lot seemed to show such variation in colour from the usual that we shot one. The distance was about two hundred and fifty yards. Immediately the whole band - a hundred or so strong - dropped on all fours and started in our direction. This was rather terrifying. However, as we stood firm, they slowly came to a halt at about seventy yards, barked and chattered for a moment, then hopped away to right and left. 


\section{XXIX \\ THE LESSER KUDU}

A BOUT eight o'clock, the evening of our first A day on the Swanee, the heat broke in a tropical downpour. We heard it coming from a long distance, like the roar of a great wind. The velvet blackness, star hung, was troubled by an invisible, blurring mist, evidenced only through a subtle effect on the subconsciousness. Every leaf above us, in the circle of our firelight, depended absolutely motionless from its stem. The insects had ceased their shrilling; the night birds their chirping; the animals, great and small, their callings or their stealthy rustling to and fro. Of the world of sound there remained only the crackling of our fires, the tiny singing of the blood in our ears, and that faroff, portentous roar. Our simple dispositions were made. Trenches had been dug around the tents; the pegs had been driven well home; our stores had been put in shelter. We waited silently, puffing away at our pipes.

The roaring increased in volume. Beneath it we 


\section{AFRICAN CAMP FIRES}

began to hear the long, rolling crash of thunder. Overhead the stars, already dimmed, were suddenly blotted from existence. Then came the rain; in a literal deluge; as though the god of floods had turned over an entire reservoir with one twist of his mighty hand. Our fire went out instantly; the whole world went out with it. We lay on our canvas cots unable to see a foot beyond our tent opening; unable to hear anything but the insistent, terrible drumming over our heads; unable to think of anything through the tumult of waters. As a man's body might struggle from behind a waterfall through the torrents, so our imaginations, half-drowned, managed dimly to picture forth little bits - the men huddled close in their tiny tents, their cowled blankets over their heads. All the rest of the universe had gone.

After a time the insistent beat and rush of waters began to wear through our patience. We willed that this wracking tumult should cease; we willed it with all the force that was in us. Then, as this proved vain, we too humped our spiritual backs, cowled our souls with patience, and waited dumbly for the force of the storm to spend itself. Our faculties were quite as effectually drowned out by the unceasing roar and crash of the waters as our bodily comfort would have been had we lacked the protection of our tent. 


\section{THE LESSER KUDU}

Abruptly the storm passed. It did not die away slowly in the diminuendo of ordinary storms. It ceased as though the reservoir had been tipped back again. The rapid drip drip drip of waters now made the whole of sound; all the rest of the world lay breathless. Then, inside our tent, a cricket struck up bravely.

This homely, cheerful little sound roused us. We went forth to count damages and to put our house in order. The men hunted out dry wood and made another fire; the creatures of the jungle and the stars above them ventured forth.

Next morning we marched into a world swept clean. The ground was as smooth as though a new broom had gone over it. Every track now was fresh, and meant an animal near at hand. The bushes and grasses were hung with jewels. Merry little showers shook down from trees sharing a joke with some tiny wind. White steam rose from a moist, fertile-looking soil. The smell of greenhouses was in the air. Looking back we were stricken motionless by the sight of Kilimanjaro, its twin peaks suspended against a clean blue sky, fresh snow mantling its shoulders.

This day, so cheeringly opened, was destined to fulfil its promise. In the dense scrub dwells a shy and rare animal called the lesser kudu, speci- 


\section{AFRICAN CAMP FIRES}

mens of which we greatly desired. The beast keeps to the thickest and driest cover, where it is impossible to see fifty yards ahead, but where the slightest movement breaks one of the numberless dry interlacements of which the place seems made. To move really quietly. one could not cover over a half mile in an hour. As the countryside extends a thousand square miles or more, and the lesser kudu is rare, it can be seen that hunting them might have to be a slow and painful process. We had twice seen their peculiar tracks.

On this morning, however, we caught a glimpse of the beast itself. A flash of gray, with an impression of the characteristic harnesslike stripes - that was all. The trail, in the soft ground, was of course very plain. I left the others, and followed it into the brush. As usual the thorn scrub was so thick that I had to stoop and twist to get through it at all, and so brittle that the least false move made a crackling like a fire. The rain of the night before had, however, softened the débris lying on the ground. I moved forward as quickly as I could, half suffocated in the steaming heat of the dense thicket. After three or four hundred yards the beast fell into a walk, so I immediately halted. I reasoned that after a few steps at this gait he would look back to see whether or not he was followed. 


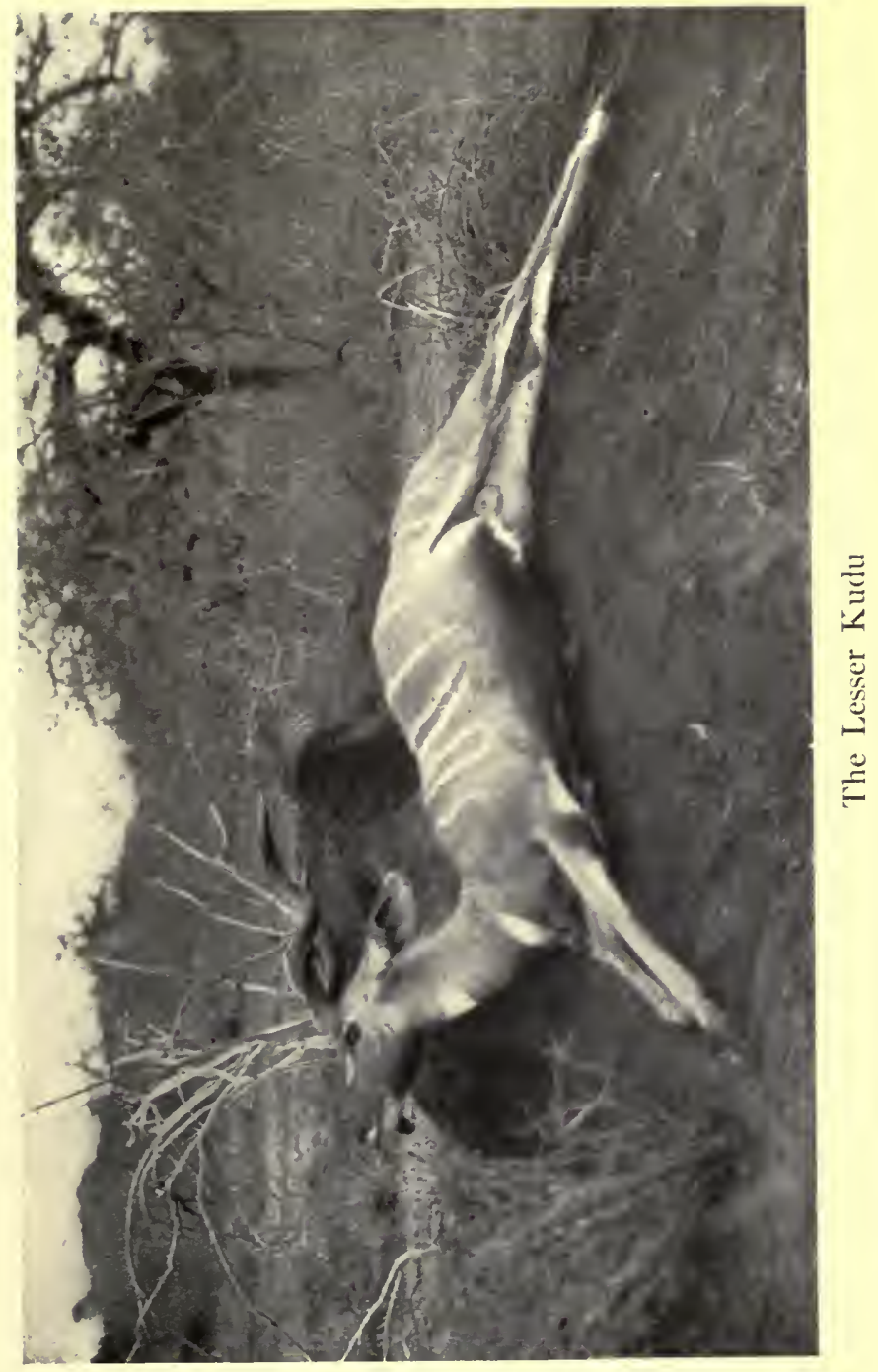




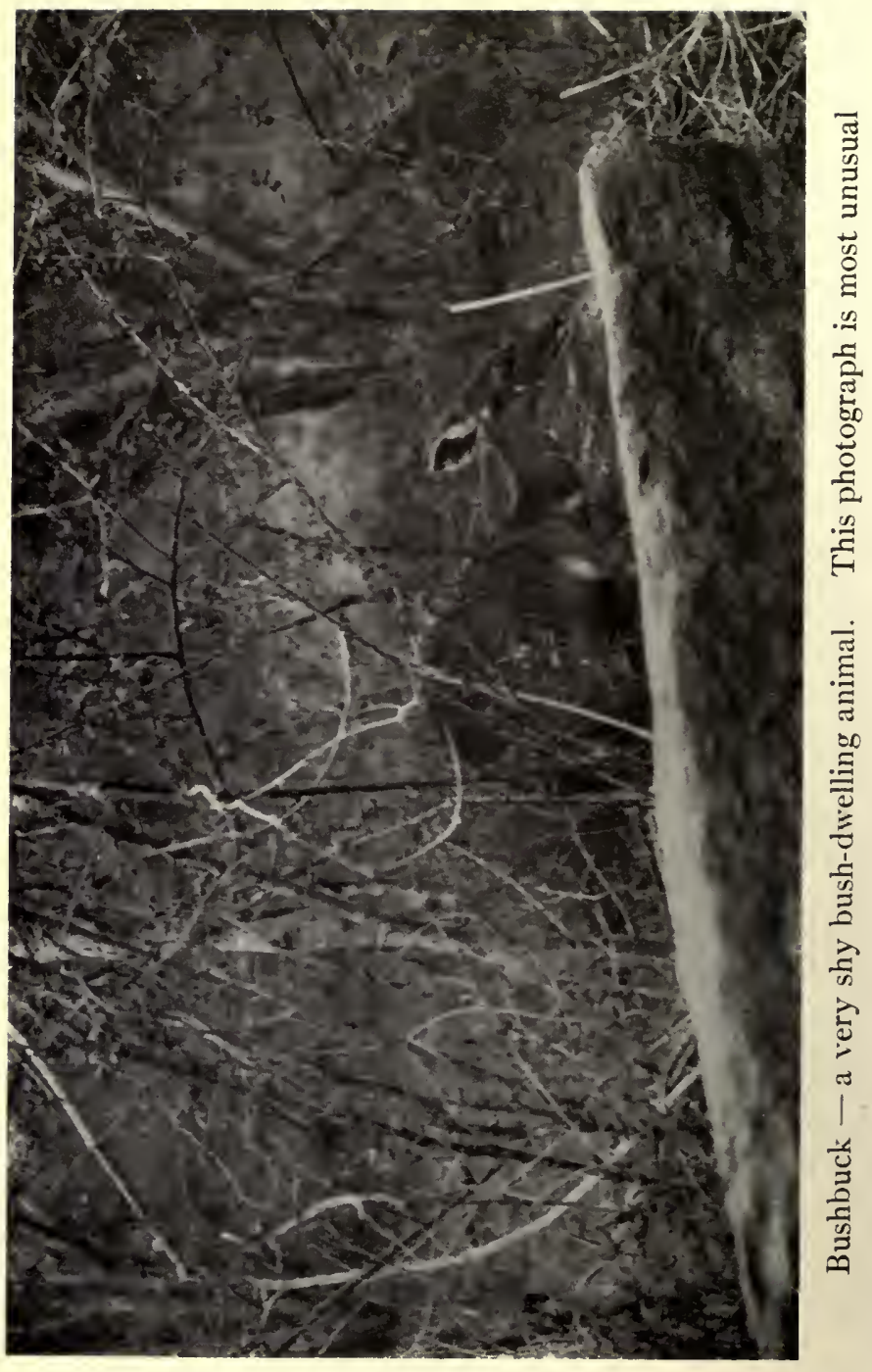




\section{THE LESSER KUDU}

If his scouting showed him noihing, he might throw off suspicion. After ten minutes I crept forward again. The spoor showed my surmises to be correct, for I came to where the animal had turned, behind a small bush, and had stood for a few minutes. Taking up the tracks from this point I was delighted to find that the kudu had forgotten its fear, and was browsing. At the end of five minutes more of very careful work, I was fortunate enough to see it, feeding from the top of a small bush thirty-five yards away. The raking shot from the Springfield dropped it in its tracks.

It proved to be a doe, a great prize of course, but not to be compared with the male. We skinned her carefully, and moved on, delighted to have the species.

Our luck was not over, however. At the end of six hours we picked our camp in a pretty grove by the swift-running stream. There we sat down to await the safari. The treetops were full of both the brown and blue monkeys, baboons barked at us from a distance, the air was musical with many sweet birds. Big thunder clouds were gathering around the horizon.

The safari came in. Mohamet immediately sought us out to report, in great excitement, that he had seen five kudu across the stream. He claimed to 


\section{AFRICAN CAMP FIRES}

have watched them even after the safari had passed; and that they had not been alarmed. The chance was slight that those kudu could be found, but still it was a chance. Accordingly we rather reluctantly gave up our plans for a loaf and a nap. Mohamet said the place was an hour back; we had had six hours' march already. However, about two o'clock we set out. Before we had arrived quite at the spot we caught a glimpse of the five kudu as they dashed across a tiny opening ahead of us. They had moved downstream and crossed the river.

It seemed rather hopeless to follow them into that thick country once they had been alarmed, but the prize was great. Therefore Memba Sasa and I took up the trail. We crept forward a mile, very quiet, very tense - very sweaty. Then simultaneously through a chance opening and a long distance away we caught a patch of gray with a single transverse white stripe. There was no chance to ascertain the sex of the beast, nor what part of its anatomy was thus exposed. I took a bull's-eye chance on that patch of gray; had the luck to hit it in the middle. The animal went down. Memba Sasa leaped forward like a madman; I could not begin to keep pace with him. When I had struggled through the thorn, I found him dancing with delight.

"Monuome, bwana! (Buck, master)!" he cried as 


\section{THE LESSER KUDU}

soon as he saw me, and made a spiral gesture in imitation of the male's beautiful corkscrew horns.

While the men prepared the trophy, F. and I followed on after the other four to see what they would do, and speedily came to the conclusion that we were lucky to land two of the wily beasts. The four ran compactly together and in a wide curve for several hundred yards. Then two faced directly back, while the other two, one on either side, made a short detour out and back to guard the flanks.

We did not get back to camp until after dark. A tremendous pair of electric storms were volleying and roaring at each other across the space of night; leopards were crying; a pack of wild dogs were barking vociferously. The camp, as we approached it, was a globe of light in a bower of darkness. The fire, shining and flickering on the under sides of the leaves, lent them a strangely unreal stagelike appearance; the porters, their half-naked bodies and red blankets catching the blaze, roasted huge chunks of meat over little fires.

We ate a belated supper in comfort, peace, and satisfaction. Then the storms joined forces and fell upon us. 


\section{$\mathrm{XXX}$}

\section{ADVENTURES BY THE WAY}

W ${ }^{E}$ journeyed slowly on down the stream. Interesting things happened to us. The impressions of that journey are of two sorts; the little isolated details and the general background of our day's routine, with the gray dawn, the great heats of the day, the blessed evening and its fireflies; the thundering of heaven's artillery, and the downpour of torrents; the hot, high, crackling thorn scrub into which we made excursions; the swift-flowing river with its palms and jungles; outleaning palms trailing their fronds just within the snatch of the flood-waters; wide flats in the embrace of the river bends, or extending into the low hills, grown thick with lush green and threaded with rhinoceros paths; the huge sheer cliff mountains over the way; distant single hills far down. The mild discomfort of the start before daylight clearly proving the thorns and stumbling blocks; the buoyant cheerfulness of the first part of the day, with the grouse rocketing straight up out of the elephant grass, the birds 


\section{ADVENTURES BY THE WAY}

singing everywhere, and the beasts of the jungle still a-graze at the edges; the growing weight of the sun, as though a great pressing hand were laid upon the shoulders; the suffocating, gasping heat of afternoon, and the gathering piling black and white clouds; the cool evening in pajamas with the fireflies flickering among the bushes, the river singing, and little breezes wandering like pattering raindrops in the dry palm leaves - all these, by repetition of main elements, blend in my memory to form a single image. To be sure each day the rock pinnacles over the way changed slightly their compass bearings, and little variations of contour lent variety to the procession of days. But in essential they were of one kin.

But here and there certain individual scenes and incidents stand out clearly and alone. Without reference to my notebook I could not tell you their chronological order, nor the days of their happening. They occurred, without correllation.

Thus one afternoon at the loafing hour, when $\mathrm{F}$. was sound asleep under his mosquito bar, and I in my canvas chair was trying to catch the breeze from an approaching deluge, to me came a total stranger in a large turban. He was without arms or baggage of any sort, an alien in a strange and savage country. 


\section{AFRICAN CAMP FIRES}

"Jambo, bwana m'kubwa! (Greeting, great master!)" said he.

"Jambo," said I, as though his existence were not in the least surprising, and went on reading. This showed him that I was indeed a great master.

After a suitable interval, I looked up.

"Wataka neenee? (What do you want?)" I demanded.

"Nataka sema qua heri (I want to say goodbye)," said this astonishing individual.

I had, until that moment, been quite unaware of his existence. As he had therefore not yet said "How do you do," I failed to fathom his reasons for wanting to say "good-bye." However, far be it from me to deny any one innocent pleasure, so I gravely bade him good-bye, and he disappeared into the howling wilderness whence he had come.

One afternoon we came upon two lemurs seated gravely side by side on a horizontal limb ten feet up a thorn tree. They contemplated us with the preternatural gravity of very young children, and without the slightest sign of fear. We coveted them as pets for Billy, but soon discovered that their apparent tameness was grounded on good solid common sense. The thorns of that thorn tree - ! We left them sitting upright, side by side. 


\section{ADVENTURES BY THE WAY}

A little farther on, and up a dry earthy side hill, a medium-sized beast leaped from an eroded place fairly under my feet and made off with a singularly familiar kiyi. It was a strange-looking animal, apparently brick red in colour. When I had collected myself I saw it was a wild dog. It had been asleep in a warm hollow of red clay, and had not awakened until I was fairly upon it. We had heard these beasts nearly every night, but this was the first we had seen. Some days later we came upon the entire pack drinking at the river. They leaped suddenly across our front eighty yards away, their heads all turned toward us truculently, barking at us like so many watch dogs. They made off, but not as though particularly alarmed.

One afternoon I had wounded a good warthog across the river; and had gone downstream to find a dry way over. F., more enthusiastic, had plunged in, and promptly attacked the warthog. He was armed with the English service revolver shooting the .455 Ely cartridge. It is a very short stubby bit of ammunition. I had often cast doubt on its driving power as compared to the .45 Colt, for example. F., as a loyal Englishman, had, of course, defended his army's weapon. When I reached the centre of disturbance I found that F. had emptied 


\section{AFRICAN CAMP FIRES}

his revolver three times - eighteen shots - into the head and forequarters of that warthog without much effect. Incidentally the warthog had given him a good lively time, charging again and again. The weapon has not nearly the shocking power of even our .38 service - a cartridge determined as too light for serious business.

One afternoon I gave my shotgun to one of the porters to carry afield, remarking facetiously to all and sundry that he looked like a gunbearer. After twenty minutes we ran across a rhinoceros. I spent some time trying to manœuvre into position for a photograph of the beast. However, the attempt failed. We managed to dodge his rush. Then, after the excitement had died, we discovered the porter and the shotgun up a tree. He descended rather shamefaced. Nobody said anything about it. A half hour later we came upon another rhinoceros. The beast was visible at some distance, and downhill. Nevertheless the porter moved a little nearer a tree. This was too much for Memba Sasa. All the rest of the afternoon he "joshed" that porter in much the same terms we would have employed in the same circumstances.

"That place ahead," said he, "looks like a good place for rhinoceros. Perhaps you'd better climb a tree." 


\section{ADVENTURES BY THE WAY}

"There is a dik-dik; a bush is big enough to climb for him."

"Are you afraid of jackals, too?"

The fireflies were our regular evening companions. We caught one or two of them for the pleasure of watching them alternately igniting and extinguishing their little lamps. Even when we put them in a bottle they still kept up their performance bravely.

But beside them we had an immense variety of evening visitors. Beetles of the most inconceivable shapes and colours, all sorts of moths, and numberless strange things - leafinsects, walking-stick insects, exactly like dry twigs, and the fierce, tall, praying mantis with their mock air of meekness and devotion. Let one of the other insects stray within reach and their piety was quickly enough abandoned! One beetle about three eighths of an inch across was oblong in shape and of pure glittering gold. His wing covers, on the other hand, were round and transparent. The effect was of a jewel under a tiny glass case. Other beetles were of red dotted with black, or of black dotted with red; they sported stripes, or circles of plain colours; they wore long slender antennæ, or short knobby horns; they carried rapiers or pinchers, long legs or short. In fact they ran the gamut of grace and horror, so that 


\section{AFRICAN CAMP FIRES}

an inebriate would find here a great rest for the imagination.

After we had gone to bed we noticed more pleasantly our cricket. He piped up, you may remember, the night of the first great storm. That evening he took up his abode in some fold or seam of our tent, and there stayed throughout all the rest of the journey. Every evening he tuned up cheerfully; and we dropped to sleep to the sound of his homelike piping. We grew very fond of him; as one does of everything in this wild and changing country that can represent a stable point of habitude.

Nor must I forget one evening when all of a sudden out of the darkness came a tremendous hollow booming, like the beating of war drums or the bellowing of some strange great beast. At length we identified the performer as an unfamiliar kind of frog! 


\section{XXXI \\ THE LOST SAFARI}

W ${ }^{\mathrm{E}}$ were possessed of a map of sorts, consisting mostly of wide blank spaces, with an occasional tentative mountain, or the probable course of streams marked thereon. The only landmark that interested us was a single round peak situated south of our river and at a point just before we should cross the railroad at Tsavo Station. There came a day when, from the top of a hill where we had climbed for the sake of the outlook, we thought we recognized that peak. It was about five miles away as the crow flies.

Then we returned to camp and made the fatal mistake of starting to figure. We ought to cover the distance, even with the inevitable twists and turns, in a day; the tri-weekly train passed through Tsavo the following night; if we could catch that we would save a two days' wait for the next train. You follow the thought. We arose very early the next morning to get a good start on our forced march.

There is no use in spinning out a sad tale. We 


\section{AFRICAN CAMP FIRES}

passed what we thought must be our landmark hill just eleven times. The map showed only one butte; as a matter of fact there were dozens. At each disappointment we had to reconstruct our theories. It is the nature of man to do this hopefully - Tsavo Station must be just around the next bend. We marched six hours without pause; then began to save ourselves a little. By all the gods of logical reasoning we proved Tsavo just beyond a certain fringe of woods. When we arrived we found that there the river broke through a range of hills by way of a deep gorge. It was a change from the everlasting scrub, with its tumbling waters, its awful cliffs, its luxuriant tropical growths; but it was by that the more difficult to make our way through. Beyond the gorge we found any amount of hills, kopjes, buttes, sugar loafs, etc., each isolated from its fellows, each perfectly competent to serve as the map's single landmark.

We should have camped, but we were very anxious to make that train; and we were convinced that now, after all that work, Tsavo could not be far away. It would be ridiculous and mortifying to find we had camped almost within sight of our destination!

The heat was very bad, and the force of the sun terrific. It seemed to possess actual physical 


\section{THE LOST SAFARI}

weight, and to press us down from above. We filled our canteens many times at the swift-running stream, and emptied them as often. By two o'clock F. was getting a little wobbly from the sun. We talked of stopping; when an unexpected thunder shower rolled out from behind the mountains, and speedily overcast the entire heavens. This shadow relieved the stress. F., much revived, insisted that we proceed. So we marched; and passed many more hills.

In the meantime it began to rain, after the wholehearted tropical fashion. In two minutes we were drenched to the skin. I kept my matches and notebook dry by placing them in the crown of my cork helmet. After the intense heat this tepid downpour seemed to us delicious.

And then, quite unexpectedly, of course, we came around a bend to make out through the sheets of rain the steel girders of the famous Tsavo bridge.*

We clambered up a steep slippery bank to the right of way, along which we proceeded half a mile to the station.

This consisted of two or three native huts, a house for the East Indian in charge, and the Station building itself. The latter was a small frame structure

*This is the point at which construction was stopped by man-eating lions. See Patterson's "The Man-eaters of Tsavo." 


\section{AFRICAN CAMP FIRES}

with a narrow floorless veranda. There was no platform. Drawing close on all sides was the interminable thorn scrub. Later, when the veil of rain had been drawn aside, we found that Tsavo, perched on a side hill, looked abroad over a wide prospect. For the moment all we saw was a dark, dismal, dripping station wherein was no sign of life.

We were beginning to get chilly, and we wanted very much some tea, fire, a chance to dry, pending the arrival of our safari. We jerked open the door and peered into the inky interior

"Babu!" yelled F., "Babu!"

From an inner back room came the faint answer in most precise English.

"I can-not come; I am pray-ing."

There followed the sharp, quick tinkle of a little bell - the Indian manner of calling upon the Lord's attention.

We both knew better than to buck the Institutions of the East; so we waited with what patience we had, listening to the intermittent tinkling of the little bell. At the end of fully fifteen minutes the devotee appeared. He proved to be a mild, deprecating little man, very eager to help, but without resources. He was a Hindu, and lived mainly on tea and rice. The rice was all out, but he expected more on the night train. There was no 


\section{THE LOST SAFARI}

trading store here. He was the only inhabitant. After a few more answers he disappeared, to return carrying two pieces of letter paper on which were tea and a little coarse native sugar. These, with a half dozen very small potatoes, were all he had to offer.

It did not look very encouraging. We had absolutely nothing in which to boil water. Of course we could not borrow of our host; caste stood in the way there. If we were even to touch one of his utensils, that utensil was for him defiled forever. Nevertheless as we had eaten nothing since four o'clock that morning, and had put a hard day's work behind us, we made an effort. After a short search we captured a savage possessed of a surfuria, or native cooking pot. Memba Sasa scrubbed this with sand. First we made tea in it, and drank turn about, from its wide edge. This warmed us up somewhat. Then we dumped in our few potatoes and a single guinea fowl that $F$. had decapitated earlier in the day. We ate; and passed the pot over to Memba Sasa.

So far, so good; but we were still very wet, and the uncomfortable thought would obtrude itself that the safari might not get in that day. It behooved us at least to dry what we had on. I hunted up Memba Sasa, whom I found in a native hut. A 


\section{AFRICAN CAMP FIRES}

fire blazed in the middle of the floor. I stooped low to enter, and squatted on my heels with the natives. Slowly I steamed off the surface moisture. We had rather a good time, chatting and laughing. After a while I looked out. It had stopped raining. Therefore I emerged and set some of the men collecting firewood. Shortly I had a fine little blaze going under the veranda roof of the station. F. and I hung out our breeches to dry, and spread the tails of our skirts over the heat. F. was actually the human chimney, for the smoke was pouring in clouds from the breast and collar of his shirt. We were fine figures for the public platform of a railway station!

We had just about dried off and had reassumed our thin and scanty garments, when the babu emerged. We stared in drop-jawed astonishment. He had muffled his head and mouth in a most brilliant scarf, as if for zero weather; although dressed otherwise in the usual pongee. Under one arm he carried a folded clumsy cotton umbrella; around his waist he had belted a huge knife; in his other hand he carried his battle-axe. I mean just that - his battle-axe. We had seen such things on tapestries or in museums, but did not dream that they still existed out of captivity. This was an oriental looking battle-axe with a handle three feet long, a spike up 


\section{THE LOST SAFARI}

top, a spike out behind, and a half-moon blade in front. The babu had with a little of his signal paint done the whole thing, blade and all, to a brilliant window-shutter green.

As soon as we had recovered our breath, we asked him very politely the reason for these stupendous preparations. It seemed that it was his habit to take a daily stroll just before sunset, "for the sake of the health," as he told us in his accurate English.

"The bush is full of bad men," he explained, "who would like to kill me; but when they see this axe and this knife they say to each other, 'There walks a very bad man. We dare not kill him." "

He marched very solemnly a quarter mile up the track and back, always in plain view. Promptly on his return he dove into his little back room where the periodic tinkling of his praying bell for some time marked his gratitude for having escaped the "bad men."

The bell ceased. Several times he came to the door, eyed us timidly, and bolted back into the darkness. Finally he approached to within ten feet, twisted his hands and giggled in a most deprecating fashion.

"What is the use of this killing game?" he gabbled as rapidly as he could. "Man should not destroy 


\section{AFRICAN CAMP FIRES}

what man cannot first create." After which he giggled again, and fled.

His conscience, evidently, had driven him to this defiance of our high and mightinesses against his sense of politeness and his fears.

About this time my boy Mohamet and the cook drifted in. They reported that they had left the safari not far back. Our hopes of supper and blankets rose. They declined, however, with the gathering darkness, and were replaced by wrath against the faithless ones. Memba Sasa, in spite of his long day, took a gun and disappeared in the darkness. He did not get back until nine o'clock, when he suddenly appeared in the doorway to lean the gun in the corner, and to announce, "Hapana safari."

We stretched ourselves on a bench and a table the floor was impossible - and took what sleep we could. In the small hours the train thundered through, the train we had hoped to catch! 


\section{XXXII}

\section{THE BABU}

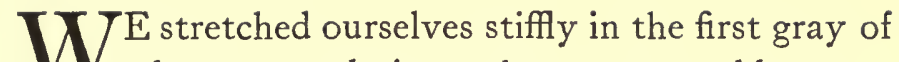
dawn, wondering where we could get a mouthful of breakfast. On emerging from the station a strange and gladsome sight met our eyes - viz., chop boxes and gun cases put off from last night's train, and belonging to some sportsman not yet arrived. Necessity knows no law; so we promptly helped ourselves to food and gun cleaning implements. Much refreshed we lit our pipes, and settled ourselves to wait for our delinquents.

Shortly after sunrise an Indian track inspector trundled in on a handcar propelled by two natives. He was a suave and corpulent person with a very large umbrella and beautiful silken garments. The natives upset the handcar off the track, and the newcomer settled himself for an enjoyable morning. He and the babu discussed ethics and metaphysical philosophy for three solid hours. Evidently they came from different parts of India, and their only common language was English. Through 


\section{AFRICAN CAMP FIRES}

the thin partition in the station building we could hear plainly every word. It was very interesting. Especially did we chortle with delight when the inspector began one of his arguments somewhat as follows:

"Now the two English who are here. They possess great sums of wealth" - F. nudged me delightedly, "and they have weapons to kill, and much with which to do things, yet their savage minds__"

It was plain, rank, eavesdropping, but most illuminating, thus to get at first hand the Eastern point of view as to ourselves; to hear the bloodless, gentle shell of Indian philosophy described by believers. They discussed the most minute and impractical points, and involved themselves in the most uncompromising dilemmas.

Thus the gist of one argument was as follows: All sexual intercourse is sin, but the race must go forward by means of sexual intercourse; therefore the race is conceived in sin and is sinful; but it is a great $\sin$ for me, as an individual, not to carry forward the race, since the Divine Will decrees that in some way the race is necessary to it. Therefore it would seem that man is in sin whichever way you look at it ——"

"But," interposes the inspector firmly but politely, "is it not possible that sexual sin and the 


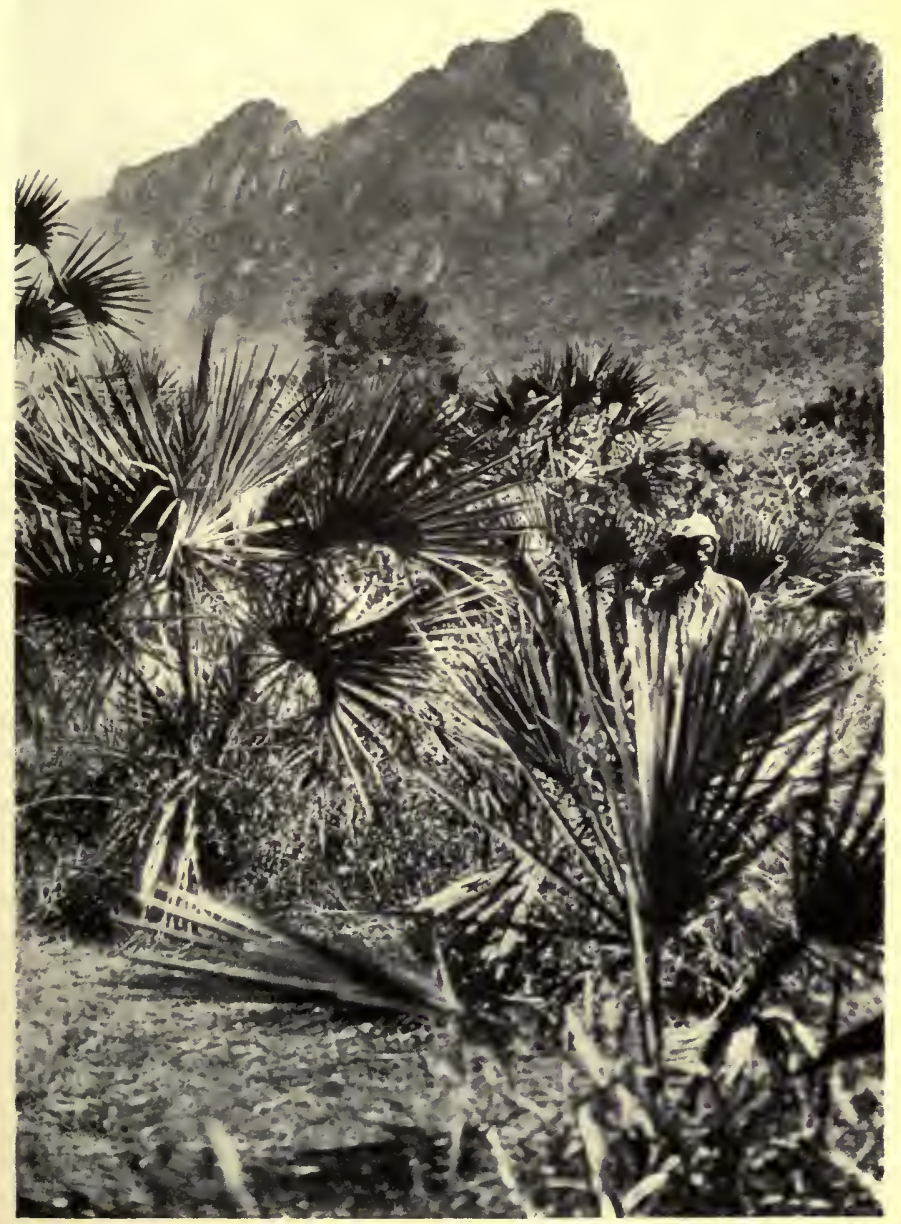

"Each day the pinnacles over the way changed slightly their compass directions" 


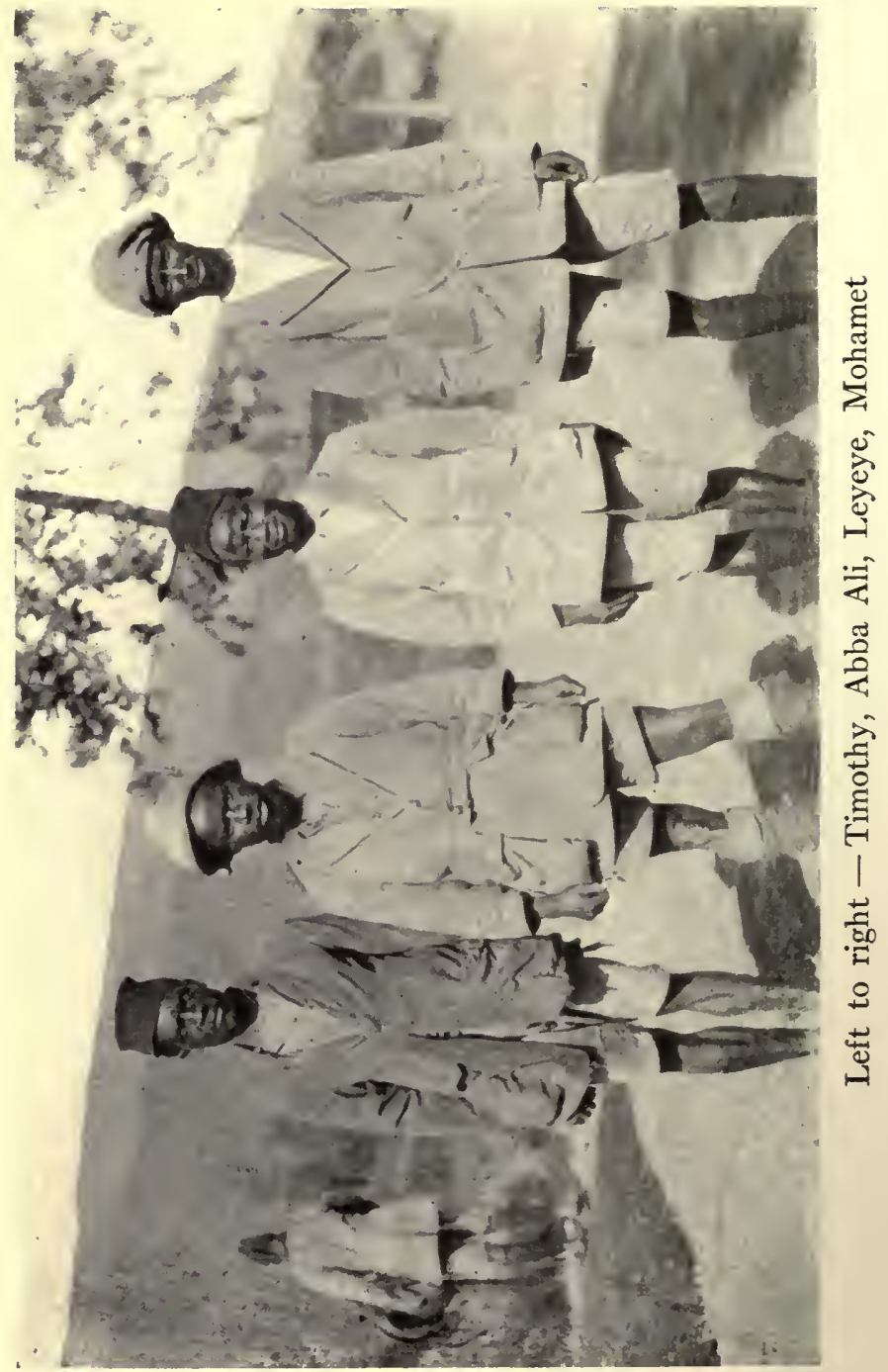




\section{THE BABU}

sin of opposing Divine Will may be of balance in the spirit, so that in resisting one sort a man acquires virtue to commit the other without harm — " And so on for hours.

At twelve-thirty the safari drifted in. Consider that fact, and what it meant. The plain duty of the headman was, of course, to have seen that the men followed us in the day before. But allowing, for the sake of argument, that this was impossible and that the men had been forced by the exhaustion of some of their number to stop and camp. If they had arisen betimes they should have completed the journey in two hours, at most. That should have brought them in by half-past seven or eight o'clock. But a noon arrival condemned them without the necessity of argument. They had camped early; had arisen very, very late; and had dawdled on the road.

We ourselves gave the two responsible headmen twenty lashes apiece; then turned over to them the job of thrashing the rest. Ten per man was the allotment. They expected the punishment; took it gracefully. Some even thanked us when it was over! The babu disappeared in his station.

About an hour later he approached us, very deprecating, and handed us a telegram. It was from the district commissioner at Voi ordering us 


\section{AFRICAN CAMP FIRES}

to report for "flogging porters on the Tsavo Station platform."

"I am truly sorry, I am truly sorry," the babu was murmuring at our elbows.

"What does this mean?" we demanded of him.

He produced a thick book.

"It is in here - the law," he explained. "You must not flog men on the station platform. It was my duty to report."

"How did we know that? Why didn't you tell us?"

"If you had gone there" - he pointed ten feet away to a spot exactly like all other spots - "it would have been off the platform. Then I had nothing to say."

We tried to become angry.

"But why in blazes couldn't you have told us of that quietly and decently? We'd have moved."

"It is the law_" He tapped his thick book.

"But we cannot be supposed ta know by heart every law in that book. Why didn't you warn us before reporting?" we insisted.

"I am truly sorry," he repeated. "I hope and trust it will not prove serious. But it is the book."

We continued in the same purposeless fashion for a moment or so longer. Then the babu ended the discussion thus: 


\section{THE BABU}

"It was my duty. I am truly sorry. Suppose I had not reported and should die to-day, and should go to heaven, and God should ask me, 'Have you done your duty to-day?' what should I say to Him?"

We gave it up; we were up against Revealed Religion.

So that night we took a freight train southward to Voi, leaving the babu and his prayer bell, and his green battle-axe and his conscience alone in the wilderness. We had quite a respect for that babu.

The district commissioner listened appreciatively to our tale.

"Of course I shall not carry the matter further," he told us, "but having known the babu, you must see, that once he had reported to me I was compelled to order you down here. I am sorry for the inconvenience."

And when we reflected on the cataclysmic upheaval that babu would have undergone had we not been summoned after breaking one of The Laws in The Book, we had to admit the district commissioner was right. 

PART VI

IN MASAILAND 



\section{XXXIII}

\section{OVER THE LIKIPIA ESCARPMENT}

WING to an outbreak of bubonic plague, and consequent quarantine, we had recruited our men outside Nairobi and had sent them, in charge of Cuninghame, to a little station up the line.

Billy and I saw to the loading of our equipment on the train, and at two o'clock, in solitary state, set forth. Our only attendants were Mohamet and Memba Sasa, who had been fumigated and inoculated and generally Red-Crossed for the purpose.

The little narrow-gauge train doubled and twisted in its climb up the range overlooking Nairobi and the Athi Plains. Fields of corn grew so tall as partially to conceal villages of round, grass-thatched huts with conical roofs; we looked down into deep ravines where grew the broad-leaved bananas; the steep hillsides had all been carefully cultivated. Savages leaning on spears watched us puff heavily by. Women, richly ornamented with copper wire or beads, toiled along bent under loads carried by 


\section{AFRICAN CAMP FIRES}

means of a band across the top of the head.* Naked children rushed out to wave at us. We were steaming quite comfortably through Africa as it had been for thousands of years before the white man came.

At Kikuyu Station we came to a halt. Kikuyu Station ordinarily embarks about two passengers a month, I suppose. Now it was utterly swamped with business, for on it had descended all our safari of thirty-nine men and three mules. Thirty of the thirty-nine yelled and shrieked and got in the wrong place, as usual. Cuninghame and the trainmen and the station master and our responsible boys heaved and tugged and directed, ordered, commanded. At length the human element was loaded to its places and locked in. Then the mules were to be urged up a very narrow gangplank into a dangerous-looking car. Quite sensibly they declined to take chances. We persuaded them. The process was quite simple. Two of the men holding the ends at a safe distance stretched a light strong cord across the beasts' hind legs, and sawed it back and forth.

We clanged the doors shut, climbed aboard, and the train at last steamed on. Now bits of forest came across our way, deep, shaded, with trailing curtain vines, and wide leaves big as table tops, and high lush impenetrable undergrowth full of flashing *After the fashion of the Canadian tump line. 


\section{OVER THE LIKIPIA ESCARPMENT}

birds, fathomless shadows and inquisitive monkeys. Occasionally we emerged to the edge of a long oval meadow, set in depressions among hills, like our Sierra meadows. Indeed so like were these openings to those in our own wooded mountains that we always experienced a distinct shock of surprise as the familiar woods parted to disclose a dark solemn savage with flashing spear.

We stopped at various stations, and descended and walked about in the gathering shadows of the forest. It was getting cool. Many little things attracted our attention, to remain in our memories as isolated pictures. Thus I remember one grave savage squatted by the track playing on a sort of mandolin-shaped instrument. It had two strings, and he twanged these alternately, without the slightest effort to change their pitch by stopping with his fingers. He bent his head sidewise, and listened with the meticulous attention of a connoisseur. We stopped at that place for fully ten minutes, but not for a second did he leave off twanging his two strings, nor did he even momentarily relax his attention.

It was now near sundown. We had been climbing steadily. The train shrieked twice, and unexpectedly slid out to the edge of the Likipia Escarpment. We looked down once more into the great Rift Valley. 


\section{AFRICAN CAMP FIRES}

The Rift Valley is as though a strip of Africa extending half the length of the continent - had in time past sunk bodily some thousands of feet, leaving a more or less sheer escarpment on either side, and preserving intact its own variegated landscape in the bottom. We were on the Likipia Escarpment. We looked across to the Mau Escarpment, where the country over which our train had been travelling continued after its interruption by the valley. And below us were mountains, streams, plains. The westering sun threw strong slants of light down and across.

The engine shut off its power, and we slid silently down the rather complicated grades and curves of the descent. A noble forest threw its shadows over us. Through the chance openings we caught glimpses of the pale country far below. Across high trestle bridges we rattled, and craned over to see the rushing white water of the mountain torrents a hundred feet down. The shriek of our engine echoed and reëchoed weirdly from the serried trunks of trees and from the great cliffs that seemed to lift themselves as we descended.

We debarked at Kijabe* well after dark. It is situated on a ledge in the escarpment, is perhaps a quarter mile wide, and includes nothing more elabo-

\footnotetext{
${ }^{*}$ Pronounce all the syllables.
} 


\section{OVER THE LIKIPIA ESCARPMENT}

rate than the station, a row of Indian dukkas, and two houses of South Africans set back toward the rise in the cliffs. A mile or so away, and on a little higher level, stand the extensive buildings of an American Mission. It is, I believe educational as well as sectarian, is situated in one of the most healthful climates of East Africa, and is prosperous.

At the moment we saw none of these things. We were too busy getting men, mules, and equipment, out of the train. Our lanterns flared in the great wind that swept down the defile; and across the track little fires flared too. Shortly we made the acquaintance of Ulyate, the South Africander who furnished us our ox teams and wagon; and of a lank, drawling youth who was to be our "rider." The latter was very anxious to get started, so we piled aboard the great wagon all our stores and equipment but those immediately necessary for the night. Then we returned to the dak-bungalow for a very belated supper. While eating this we discussed our plans.

These were in essence very simple. Somewhere south of the great Thirst of the Sotik was a river called the Naróssara. Back of the river were high mountains, and down the river were benches dropping off by thousands of feet to the barren country of Lake Maghadi. Over some of this country ranged 


\section{AFRICAN CAMP FIRES}

the greater kudu, easily the prize buck of East Africa. We intended to try for a greater kudu.

People laughed at us. The beast is extremely rare; it ranges over a wide area; it inhabits the thickest sort of cover in a sheer mountainous country; its senses are wonderfully acute; and it is very wary. A man might, once in a blue moon, get one by happening upon it accidentally; but deliberately to go after it was sheer lunacy. So we were told. As a matter of fact, we thought so ourselves, but greater kudu was as good an excuse as another.

The most immediate of our physical difficulties was the Thirst. Six miles from Kijabe we would leave the Kedong River. After that was no more water for two days and nights. During that time we should be forced to travel and rest in alternation day and night; with a great deal of travel and very little rest. We should be able to carry for the men a limited amount of water on the ox wagon; but the cattle could not drink. It was a hard, anxious grind. A day's journey beyond the first water after the Thirst we should cross the Southern Guaso Nyero River.* Then two days should land us at the Naróssara. There we must leave our ox wagon and push on with our tiny safari. We planned to relay back for patio from our different camps.

*An entirely different stream from that flowing north of Mt. Kenia. 


\section{OVER THE LIKIPIA ESCARPMENT}

That was our whole plan. Our transport rider's object in starting this night was to reach the Kedong River, and there to outspan until our arrival next day. The cattle would thus get a good feed and rest. Then at four in the afternoon we would set out to conquer the Thirst. After that it would be a question of travelling to suit the oxen.

Next morning, when we arose, we found one of the wagon Kikuyus awaiting us. His tale ran that after going four miles, the oxen had been stampeded by lions. In the mix-up the dusselboom had been broken. He demanded a new dusselboom. I looked as wise as though I knew just what that meant; and told him, largely, to help himself. Shortly he departed carrying what looked to be the greater part of a forest tree.

We were in no hurry, so we did not try to get our safari under way before eight o'clock. It consisted of twenty nine porters, the gunbearers, three personal boys, three syces, and the cook. Of this lot some few stand out from the rest, and deserve particular attention.

Of course I had my veterans, Memba Sasa and Mohamet. There was also Kongoni, gunbearer, elsewhere described. The third gunbearer was Mavrouki, a Wakamba. He was the personal gunbearer of a Mr. Twigg, who very courteously loaned 


\section{AFRICAN CAMP FIRES}

him for this trip as possessing some knowledge of the country. He was a small person, with stripes about his eyes; dressed in a Scotch highland cap, khaki breeches, and a shooting coat miles too big for him. His soul was earnest, his courage great, his training good, his intelligence none too brilliant. Timothy, our cook, was pure Swahili. He was a thin, elderly individual, with a wrinkled brow of care. This represented a conscientious soul. He tried hard to please, but he never could quite forget that he had cooked for the Governor's safari. His air was always one of silent disapproval of our modest outfit. So well did he do, however, often under trying circumstances, that at the close of the expedition Billy presented him with a very fancy knife. To her vast astonishment he burst into violent sobs.

"Why, what is it?" she asked.

"Oh, memsahib," he wailed, "I wanted a watch!"

As personal boy Billy had a Masai named Leyeye.* The members of this proud and aristocratic tribe rarely condescend to work for the white man; but when they do, they are very fine servants, for they are highly intelligent. Leyeye was short and very, very ugly. Perhaps this may partly explain his leaving tribal life; for the Masai generally are over six feet.

*Pionounce coery syllable. 


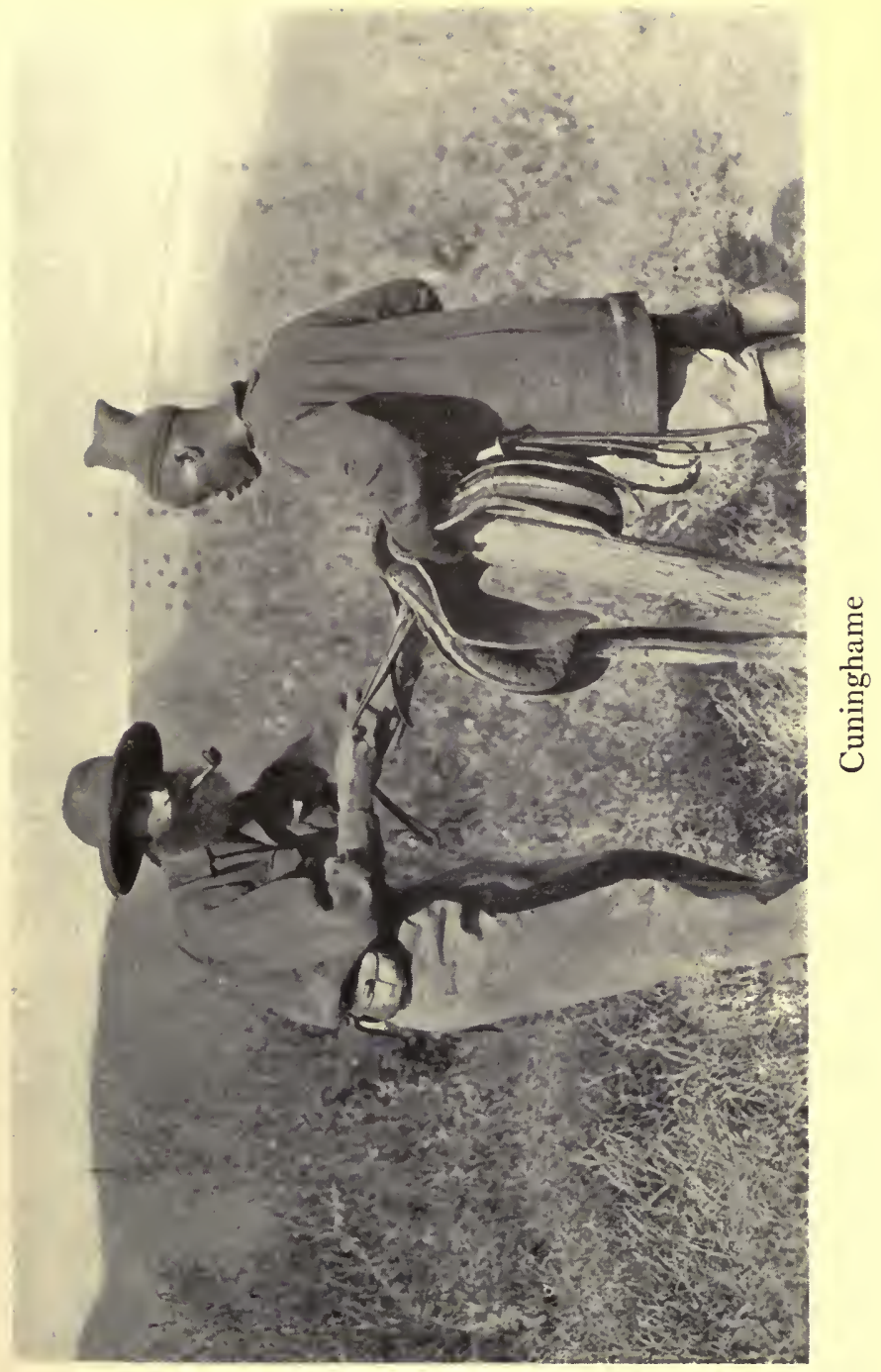




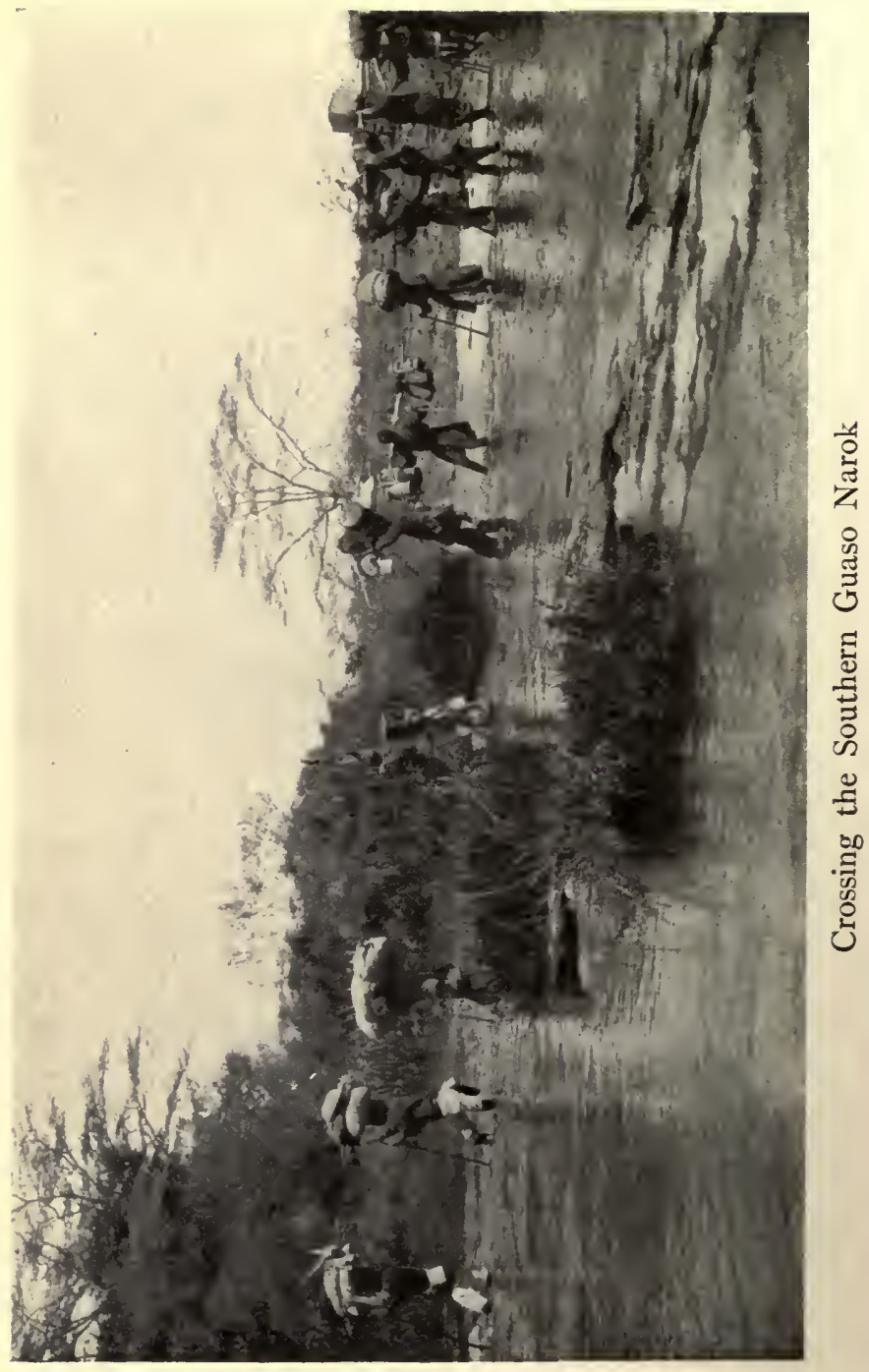




\section{OVER THE LIKIPIA ESCARPMENT}

Cuninghame's man was an educated coast Swahili named Abba Ali. This individual was very smart. He wore a neatly trimmed Vandyke beard, a flannel boating hat, smart tailored khakis, and carried a rattan cane. He was alert, quick, and intelligent. His position was midway between that of personal boy and headman.

Of the rank and file we began with twenty-nine. Two changed their minds before we were fairly started and departed in the night. There was no time to get regular porters; but fortunately a Kikuyu chief detailed two wild savages from his tribe to act as carriers. These two children of nature drifted in with pleasant smiles, and little else save knickknacks. From our supplies we gave them two thin jerseys, reaching nearly to the knees. Next day they appeared with broad tucks sewed around the middle! They looked like "My mama didn't use wool soap." We then gave it up, and left them free and untrammelled.

They differed radically. One was past the first enthusiasms and vanities of youth. He was small, unobtrusive, unornamented. He had no possessions save the jersey, the water bottle and the blanket we ourselves supplied. The blanket he crossed bandolier fashion on one shoulder. It hung down behind like a tasselled sash. His face was little and wizened 


\section{AFRICAN CAMP FIRES}

and old. He was quiet and uncomplaining, and the "easy mark" for all the rest. We had constantly to be interfering to save him from imposition as to too heavy loads, too many chores and the like. Nearing the close of the long expedition, when our loads were lighter and fewer, one day Cuninghame spoke up.

"I'm going to give the old man a good time," said he, "I doubt if he's ever had one before, or if he ever will again. He's that sort of a meek damn fool."

So it was decreed that Kimau* should carry nothing for the rest of the trip, was to do no more work, was to have all he wanted to eat. It was a treat to see him. He accepted these things without surprise, without spoken thanks; just as he would have accepted an increased supply of work and kicks. Before his little fire he squatted all day, gazing vacantly off into space, or gnawing on a piece of the meat he always kept roasting on sticks. He spoke to no one; he never smiled or displayed any obvious signs of enjoyment; but from him radiated a feeling of deep content.

His companion savage was a young blood, and still affected by the vanities of life. His hair he wore in short tight curls, resembling the rope hair of

\footnotetext{
*His official name was Lightfoot Queen of the Fairies because of his balletlike costume.
} 


\section{OVER THE LIKIPIA ESCARPMENT}

a French poodle, liberally anointed with castor-oil and coloured with red-paint clay. His body too was turned to bronze by the same method; so that he looked like a beautiful smooth metal statue come to life. To set this quality off he wore glittering collars, bracelets, anklets, and ear ornaments of polished copper and brass. When he joined us his sole costume was a negligent two-foot strip of cotton cloth. After he had received his official jersey, he carefully tied the cloth over his wonderful head; nor as far as we knew did he again remove it until the end of the expedition. All his movements were inexpressibly graceful. They reminded one somehow of Flaxman's drawings of the Greek gods. His face, too, was good-natured and likable. A certain half feminine, wild grace, combined with the queer effect of his headgear, caused us to name him Daphne. At home he was called Kingangui.

At first he carried his burden after the fashion of savages - on the back; and kept to the rear of the procession; and at evening consorted only with old Lightfoot. As soon as opportunity offered he built himself a marvellous iridescent ball of marabout feathers. Each of these he split along the quill, so that they curled and writhed in the wind. This picturesque charm he suspended from a short pole in front of his tent. Also, since he belonged to the Kikuyu 


\section{AFRICAN CAMP FIRES}

tribe, he ate no game meat; but confined his diet to cornmeal potio. We were much interested in watching Daphne's gradual conversion from savage ways to those of the regular porter. Within two weeks he was carrying his load on his head or shoulder, and trying to keep up near the head of the safari. The charm of feathers disappeared shortly after, I am sorry to say. He took his share of the meat. Within two months Daphne was imitating as closely as possible the manners and customs of his safari mates. But he never really succeeded in looking anything but the wild and graceful savage he was. 


\section{XXXIV \\ TO THE KEDONG}

4 OR four hours we descended the valley through high thorn scrub, or the occasional grassy openings. We were now in the floor of the Rift Valley, and both along the escarpments and in the floor of the great blue valley itself mountains were all about us. Most of the large ones were evidently craters; and everywhere were smaller kopjes or buttes, that in their day had also served as blow holes for subterranean fires.

At the end of this time we arrived at the place where we were supposed to find the wagon. No wagon was there.

The spot was in the middle of a level plain on which grew very scattered bushes, a great deal like the sparser mesquite growths of Arizona. Toward the Likipia Escarpment, and about halfway to its base, a line of trees marked the course of the Kedong River. Beyond that, fairly against the mountain, we made out a settler's house.

Leaving Billy and the safari, Cuninghame and I set 


\section{AFRICAN CAMP FIRES}

out for this house. The distance was long, and we had not made half of it before thunder clouds began to gather. They came up thick and black behind the escarpment, and rapidly spread over the entire heavens. We found the wagon shortly, still mending its dusselboom, or whatever the thing was. Leaving instructions for it to proceed to a certain point on the Kedong River, we started back for our safari.

It rained. In ten minutes the dusty plains, as far as the eye could reach, were covered with water two or three inches deep, from which the sparse bunches of grasses grew like reeds in a great marshy lake. We splashed along with the water over our ankles. The channels made by the game trails offered natural conduits, and wherever there was the least grade they had become rushing brooks. We found the safari very bedraggled. Billy had made a mound of valuables atop which she perched, her waterproof cape spread as wide as possible, a good deal like a brooding hen. We set out for the meeting point on the Kedong. In half an hour we had there found a bit of higher ground and had made camp.

As suddenly as they had gathered the storm clouds broke away. The expiring sun sent across the valley a flood of golden light, that gilded the rugged old mountain of Suswa over the way. 


\section{TO THE KEDONG}

"Directly on the other side of Suswa," Cuninghame told me, "there is a 'pan' of hard clay. This rain will fill it; and we shall find water there. We can take a night's rest, and set off comfortably in the morning."

So the rain that had soaked us so thoroughly was a blessing after all. While we were cooking supper the wagon passed us, its wheels and frame creaking, its great whip cracking like a rifle, its men shrieking at the imperturbable team of eighteen oxen. It would travel until the oxen wanted to graze, or sleep, or scratch an ear, or meditate on why is a Kikuyu. Thereupon they would be outspanned and allowed to do it, whatever it was, until they were ready to go on again. Then they would go on. These sequences might take place at any time of the day or night, and for greater or lesser intervals of time. That was distinctly up to the oxen; the human beings had mighty little to say in the matter. But transport riding, from the point of view of the rank outsider, really deserves a chapter of its own. 


\section{XXXV \\ THE TRANSPORT RIDER}

$7 \mathrm{HE}$ wagon is one evolved in South Africa, a 1 long, heavily constructed affair, with ingenious braces and timbers so arranged as to furnish the maximum clearance with the greatest facility for substitution in case the necessity for repairs might arise. The whole vehicle can be dismounted and reassembled in a few hours; so that unfordable streams or impossible bits of country can be crossed piecemeal. Its enormous wheels are set wide apart. The brake is worked by a crank at the rear; like a reversal of the starting mechanism of a motor car. Bolted to the frame on either side between the front and rear wheels are capacious cupboards, and two stout water kegs swing to and fro when the craft is under way. The net carrying capacity of such a wagon is from three to four thousand pounds.

This formidable vehicle in our own case was drawn by a team of eighteen oxen. The biggest brutes, the wheelers, were attached to a tongue; all the others pulled on a long chain. The only 


\section{THE TRANSPORT RIDER}

harness was the pronged yoke that fitted just forward of the hump. Over rough country the wheelers were banged and jerked about savagely by the tongue; they did not seem to mind it, but exhibited a certain amount of intelligence in manipulation.

To drive these oxen we had one white man, named Brown, and two small Kikuyu savages. One of these worked the brake crank in the rear; while the other preceded the lead cattle. Brown exercised general supervision, a long lashed whip, and BoerDutch expletives and admonitions.

In transport riding, as this game is called, there is required a great amount of especial skill, though not necessarily a high degree of intelligence. Along the flats all goes well enough; but once in the unbelievable rough country of a hill trek the situation alters. A man must know cattle and their symptoms. It is no light feat to wake up eighteen sluggish bovine minds to the necessity for effort, and then to throw so much dynamic energy into the situation that the whole eighteen will begin to pull at once. That is the secret; unanimity. An ox is the most easily discouraged working animal on earth. If the first three couples begin to haul before the others have aroused to their effort, they will not succeed in budging the wagon an inch, but after a moment's struggle will give up completely. By that 


\section{AFRICAN CAMP FIRES}

time the leaders respond to the command and throw themselves forward in the yoke. In vain. They cannot pull the wagon and their wheel comrades too. Therefore they give up. By this time, perhaps, the lash has aroused the first lot to another effort. And so they go, pulling and hauling against each other, getting nowhere, until the end is an exhausted team, a driver half insane, and a great necessity for unloading.

A good driver on the other hand, shrieks a few premonitory Dutch words - and then! I suppose inside those bovine heads the effect is somewhat that of a violent electric explosion. At any rate it hits them all at once; and all together, in response, they surge against their yokes. The heavily laden wagon creaks, groans, moves forward. The hurricane of Dutch and the volleys of whip crackings rise to a crescendo. We are off!

To perform just this little simple trick of getting the thing started requires not only a peculiar skill or gift, but also lungs of brass and a throat of iron. A transport rider without a voice is as a tenor in the same fix. He may - and does - get so hoarse that it is a pain to hear him; but as long as he can croak in good volume he is all right. Mere shouting will not do. He must shriek, until to the sympathetic bystander it seems that his throat must 


\section{THE TRANSPORT RIDER}

split wide open. Furthermore, he must shriek the proper things. It all sounds alike to every one but transport riders and oxen; but as a matter of fact it is Boer-Dutch, nicely assorted to suit different occasions. It is incredible that oxen should distinguish; but, then, it is also incredible that trout should distinguish the nice differences in artificial flies.

After the start has been made successfully, the craft must be kept under way. To an unbiased bystander the whole affair looks insane. The wagon creaks and sways and groans and cries aloud as it bumps over great boulders in the way; the leading Kikuyu dances nimbly and shrills remarks at the nearest cattle; the tail Kikuyu winds energetically back and forth on his little handle, and tries to keep his feet. And Brown! he is magnificent! His long lash sends out a volley of rifle reports, down, up, ahead, back; his cracked voice roars out an unending stream of apparent gibberish. Back and forth along the line of the team he skips nimbly, the sweat streaming from his face. And the oxen plod along, unhasting, unexcited, their eyes dreamy, chewing the end of yesterday's philosophic reflection. The situation conveys the general impression of a peevish little stream breaking against great calm cliffs. All this frantic excitement and expenditure of energy is so 


\section{AFRICAN CAMP FIRES}

apparently purposeless and futile, the calm cattle seem so aloof and superior to it all, so absolutely unaffected by it. They are going slowly, to be sure, their gait may be maddeningly deliberate, but evidently they do not intend to be hurried. Why not let them take their own speed?

But all this hullabaloo means something, after all. It does its business, and the top of the boulderstrewn hill is gained. Without it the whole concern would have stopped; and then the wagon would have had to be unloaded before a fresh start could have been made. Results with cattle are not shown by facial expression nor by increased speed, but simply by continuance. They will plod up steep hills or along the level at the same placid gait. Only in the former case they require especial treatment.

In case the wagon gets stuck on a hill, as will occasionally happen, so that all the oxen are discouraged at once, we would see one of the Kikuyus leading the team back and forth, back and forth, on the side hill just ahead of the wagon. This is to confuse their minds, cause them to forget their failure, and thus to make another attempt.

At one stretch we had three days of real mountains. N'gombe* Brown shrieked like a steam calliope all the way through. He lasted the distance, * N'gombe-oxen. 


\section{THE TRANSPOR'T RIDER}

but had little campfire conversation even with his beloved Kikuyus.

When the team was outspanned, which in the waterless country of forced marches is likely to be almost any time of the day or night, N'gombe Brown sought a little rest. For this purpose he had a sort of bunk that let down underneath the wagon. If it was daytime, the cattle were allowed to graze under supervision of one of the Kikuyus. If it was night time they were tethered to the long chain, where they lay in a somnolent double row. A lantern at the head of the file and one at the wagon's tail were supposed to discourage lions. In a bad lion country fires were added to these defences.

N'gombe Brown thus worked hard all of varied and long hours in strict intimacy with stupid and exasperating beasts. After working hours he liked to wander out to watch those same beasts grazing! His mind was as full of cattle as that! Although we offered him reading matter, he never seemed to care for it, nor for long-continued conversation with white people not of his trade. In fact the only gleam of interest I could get out of him was by commenting on the qualities or peculiarities of the oxen. He had a small mouth organ on which he occasionally performed, and would hold forth for hours with his childlike Kikuyus. In the intelli- 


\section{AFRICAN CAMP FIRES}

gence to follow ordinary directions he was an infant. We had to iterate and reiterate in words of one syllable our directions as to routes and meeting points, and then he was quite as apt to go wrong as right. Yet, I must repeat, he knew thoroughly all the ins and outs of a very difficult trade, and understood, as well, how to keep his cattle always fit and in good condition. In fact he was a little hipped on what the "dear n'gombes" should or should not be called upon to do.

One incident will illustrate all this better than I could explain it. When we reached the Naróssara River we left the wagon and pushed on afoot. We were to be gone an indefinite time; and we left N'gombe Brown and his outfit very well fixed. Along the Naróssara ran a pleasant shady strip of high jungle; the country about was clear and open; but most important of all, a white man of education and personal charm occupied a trading boma, or enclosure, near at hand. An accident changed our plans and brought us back unexpectedly at the end of a few weeks. We found that N'gombe Brown had trekked back a long day's journey, and was encamped alone at the end of a spur of mountains. We sent native runners after him. He explained his change of base by saying that the cattle feed was a little better at his new camp! Mind you this; at 


\section{THE TRANSPORT RIDER}

the Naróssara the feed was plenty good enough, the oxen were doing no work, there was companionship, books, papers, and even a phonograph to while away the long weeks until our return. N'gombe Brown quite cheerfully deserted all this, to live in solitude where he imagined the feed to be microscopically better! 


\section{XXXVI}

\section{ACROSS THE THIRST}

W ${ }^{E}$ were off a bright, clear day after the rains. Suswa hung grayish pink against the bluest of skies. Our way slanted across the Rift Valley to her base; turned the corner, and continued on the other side of the great peak until we had reached the rainwater "pan" on her farther side. It was a long march.

The plains were very wide and roomy. Here and there on them rose many small cones and craters, lava flows and other varied evidences of recent volcanic activity. Geologically recent, I mean. The grasses of the flowing plains were very brown, and the molehill craters very dark; the larger craters blasted and austere; the higher escarpment in the background blue with a solemn distance. The sizes of things were not originally fitted out for little tiny people like human beings. We walked hours to reach landmarks apparently only a few miles away.

In this manner we plodded along industriously un278 


\section{ACROSS THE THIRST}

til noon, by which time we had nearly reached the shoulder of Suswa, around which we had to double. The sun was strong, and the men not yet hardened to the work. We had many stragglers. After lunch Memba Sasa and I strolled along on a route flanking that of the safari looking for the first of our meat supply. Within a short time I had killed a Thompson's gazelle. Some solemn giraffes looked on at the performance, and then moved off liked mechanical toys.

The day lengthened. We were in the midst of wonderful scenery. Our objection grew to be that it took so long to put any of it behind us. Insensibly, however, we made progress. Suddenly, as it seemed, we found ourselves looking at the other side of Suswa, and various brand-new little craters had moved up to take the places of our old friends. At last, about half-past four, we topped the swell of one of the numerous and interminable land billows that undulate across all plains countries here, and saw, a few miles away, the wagon outspanned. We reached it about sunset, to be greeted by the welcome news that there was indeed water in the pan.

We unsaddled just before dark, and I immediately started toward the game herds, many of which were grazing a half mile away. The gazelle would supply 


\section{AFRICAN CAMP FIRES}

our own larder, but meat for hard-worked men was very desirable. I shot a hartebeeste, made the prearranged signal for men to carry meat, and returned to camp.

Even yet the men were not all in. We took lanterns and returned along the road; for the long marches under a desert sun are no joke. At last we had accounted for all but two. These we had to abandon. Next day we found their loads, but never laid eyes on them again. Thus early our twenty-nine became twenty-seven.

About nine o'clock, about as we were turning, in a number of lions began to roar. Usually a lion roars once or twice by way of satisfaction after leaving a kill. These, however, were engaged in driving game, and hence trying to make as much noise as possible. We distinguished plainly seven individuals, perhaps more. The air trembled with the sound as to the deepest tones of a big organ, only the organ is near and enclosed, while these vibrations were in the open air and remote. For a few moments the great salvos would boom across the veldt, roll after roll of thunder; then would ensue a momentary dead silence; then a single voice would open, to be joined immediately by the others.

We awoke next day to an unexpected cold drizzle. This was a bit uncomfortable, from one point of 

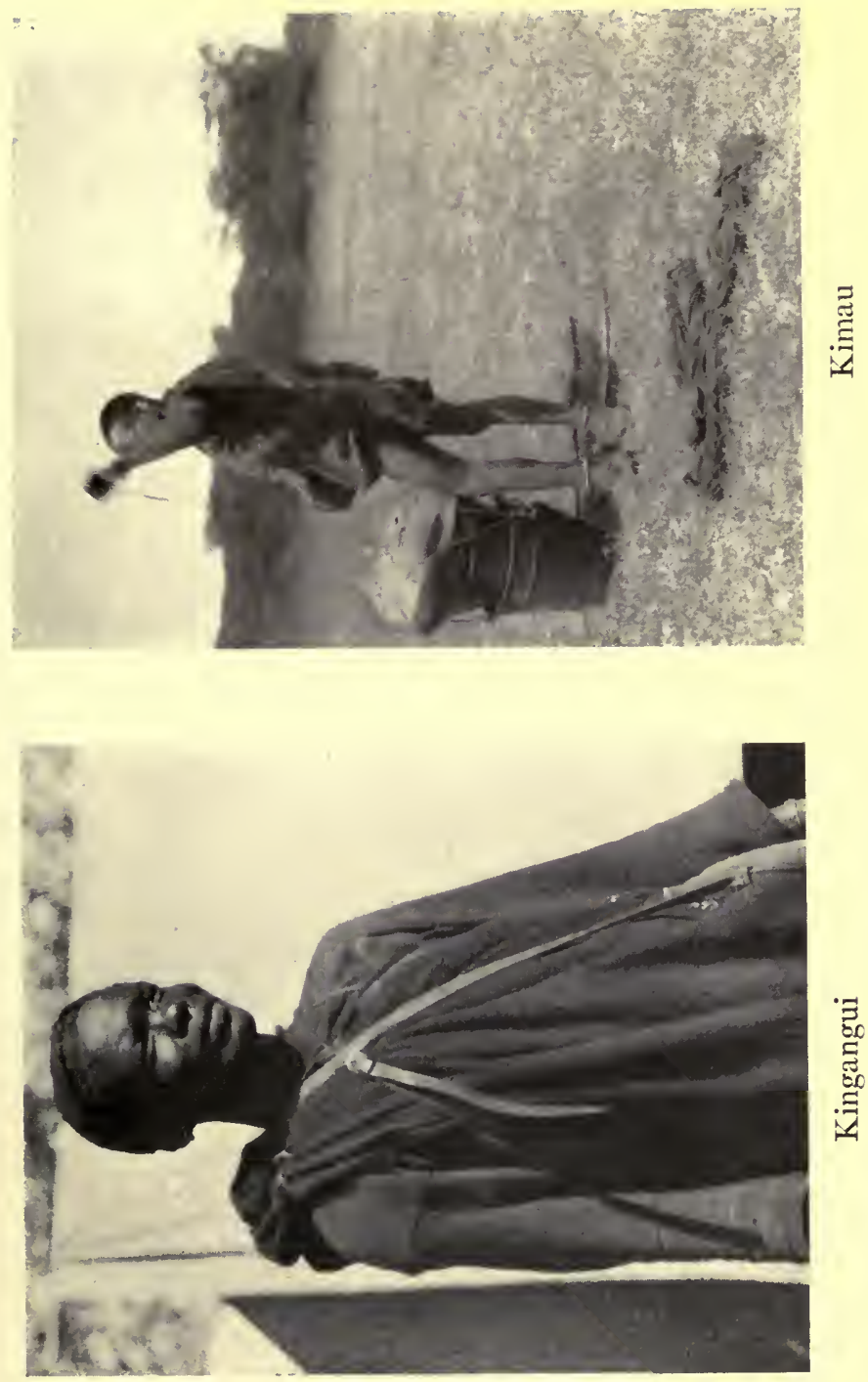

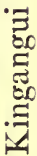




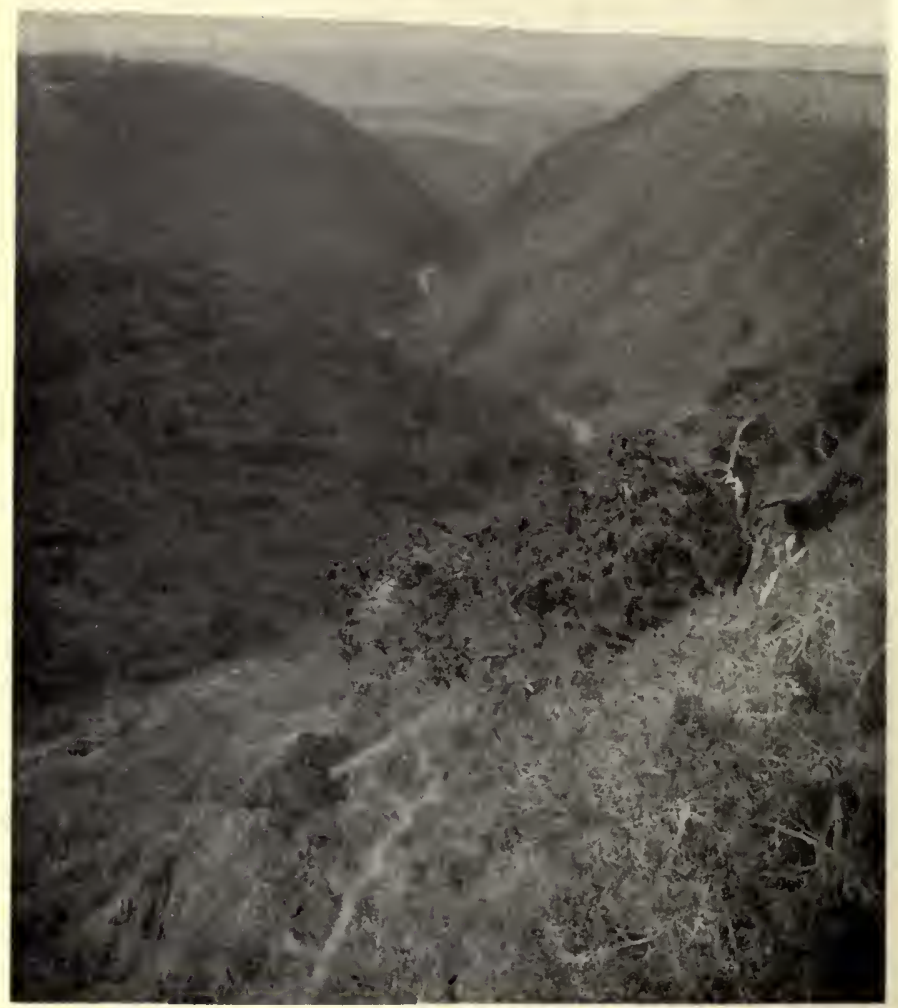

"From it we looked down into the deep gorge of the Southern Guaso Nyero" 


\section{ACROSS THE THIRST}

view, and most unusual, but it robbed the Thirst of its terrors. We were enabled to proceed leisurely, and to get a good sleep near water every night. The wagon had, as usual, pulled out some time during the night.

Our way led over a succession of low rolling ridges each higher that its predecessor. Game herds fed in the shallow valleys between. At about ten o'clock we came to the foot of the Mau Escarpment; and also to the unexpected sight of the wagon outspanned. N'gombe Brown explained to us that the oxen had refused to proceed farther in face of a number of lions that came around to sniff at them. Then the rain had come on, and he had been unwilling to attempt the Mau while the footing was slippery. This sounded reasonable; in fact it was still reasonable. The grass was here fairly neck high, and we found a rain-filled water hole. Therefore we decided to make camp. Cuninghame and I wandered out in search of game. We tramped a great deal of bold, rugged country, both in cañon bottoms and along the open ridges, but found only a rhinoceros, one bush buck and a dozen hartebeeste. African game, as a general rule, avoids a country where the grass grows very high. We enjoyed, however, some bold and wonderful mountain scenery; and obtained glimpses through the flying murk of the vast plains 


\section{AFRICAN CAMP FIRES}

at the base of Suswa. On a precipitous cañon cliff we found a hanging garden of cactus and of looped cactuslike vines that was a marvel to behold. We ran across the hartebeeste on our way home. Our men were already out of meat: the hartebeeste of yesterday had disappeared. These porters are a good deal like the old-fashioned Michigan lumberjacks - they take a good deal of feeding for the first few days. When we came upon the little herd in the neck-high grass, I took a shot. At the report the animal went down flat. We wandered over slowly. Memba Sasa whetted his knife and walked up. Thereupon Mr. Hartebeeste jumped to his feet; flirted his tail gayly, and departed. We followed him a mile or so, but he got stronger and gayer every moment; until at last he frisked out of the landscape quite strong and hearty. In all my African experience I lost only six animals hit by bullets, as I took infinite pains and any amount of time to hunt down wounded beasts. This animal was, I think, "creased" by too high a shot. Certainly he was not much injured; and certainly he got a big shock to start with.

The little herd had gone on. I got down and crawled on hands and knees in the thick grass. It was slow work; and I had to travel by landmarks. When I finally reckoned I had about reached the 


\section{ACROSS THE THIRST}

proper place, I stood up suddenly, my rifle at ready. So dense was the cover and so still the air that I had actually crawled right into the middle of the band! While we were cutting up the meat the sun broke through strongly.

Therefore the wagon started on up the Mau at six o'clock. Twelve hours later we followed. The fine drizzle had set in again. We were very glad the wagon had taken advantage of the brief dry time.

From the top of the sheer rise we looked back for the last time over the wonderful panorama of the Rift Valley. Before us were wide rounded hills covered with a scattered small growth that in general appearance resembled scrub oak. It sloped away gently until it was lost in mists. Later, when these cleared, we saw distant blue mountains across a tremendous shallow basin. We were nearly on a level with the summit of Suswa itself, nor did we again drop much below that altitude. After five or six miles we overtook the wagon outspanned. The projected all-night journey had again been frustrated by the lions. These beasts had proved so bold and menacing that finally the team had been forced to stop in sheer self-defence. However, the day was cool and overcast, so nothing was lost.

After topping the Mau we saw a few gazelle, 


\section{AFRICAN CAMP FIRES}

zebra, and hartebeeste; but soon plunged into a bush country quite destitute of game. We were paralleling the highest ridge of the escarpment; and so alternated between the crossing of cañons and the travelling along broad ridges between them. In lack of other amusement for a long time I rode with the wagon. The country was very rough and rocky. Everybody was excited to the point of frenzy, except the wagon. It had a certain Dutch stolidity in its manner of calmly and bumpily surmounting such portions of the landscape as happened in its way.

After a very long tiresome march we camped above a little stream. Barring our lucky rain this would have been the first water since leaving the Kedong River. Here were hundreds of big blue pigeons swooping in to their evening drink.

For two days more we repeated this sort of travel; but always with good camps at fair-sized streams. Gradually we slanted away from the main ridge; though we still continued cross-cutting the swells and ravines thrown off its flanks. Only the ravines hour by hour became shallower, and the swells lower and broader. On their tops the scrub sometimes gave way to openings of short-grass. On these fed a few gazelle of both sorts, and an occasional zebra or so. We saw also four topi, a beast about the 


\section{ACROSS THE THIRST}

size of our caribou, built on the general specifications of a hartebeeste, but with the most beautiful iridescent plum-coloured coats. This quartette was very wild. I made three separate stalks on them, but the best I could do was 360 paces, at which range I missed.

Finally we surmounted the last low swell to look down a wide and sloping plain to the depression in which flowed the principal river of these parts, the Southern Guaso Nyero. Beyond it stretched the immense oceanlike plains of the Loieta, from which here and there rose isolated hills, very distant, like lonseome ships at sea. A little to the left, also very distant, we could make out an unbroken blue range of mountains. These were our ultimate destination. 


\section{XXXVII}

\section{THE SOUTHERN GUASO NYERO}

$7 \mathrm{HE}$ southern Guaso Nyero, unlike its northern 1 namesake, is a sluggish muddy stream, rather small, flowing between abrupt clay banks. Farther down it drops into great cañons and eroded abysses, and acquires a certain grandeur. But here, at the ford of Agate's Drift, it is decidedly unimpressive. Scant greenery ornaments its banks. In fact, at most places they run hard and baked to a sheer drop-off of ten or fifteen feet. Scattered mimosa trees and aloes mark its course. The earth for a mile or so is trampled by thousands of Masai cattle that at certain seasons pass through the funnel of this, the only ford for miles Apparently insignificant, it is given to sudden, tremendous rises. These originate in the rainfalls of the upper Mau Escarpment, many miles away. It behooves the safari to cross promptly if it can; and to camp always on the farther bank.

This we did, pitching our tents in a little opening, between clumps of pretty flowering aloes and the 


\section{THE SOUTHERN GUASO NYERO}

mimosas. Here, as everywhere in this country until we had passed the barrier of the Narossara mountains, the common houseflies were a plague. They follow the Masai cattle. I can give you no better idea of their numbers than to tell you two isolated facts; I killed twenty-one at one blow; and in the morning before sunrise the apex of our tent held a solid black mass of the creatures running the length of the ridge pole, and from half an inch to two inches deep! Every pack was black with them on the march; and the wagon carried its millions. When the shadow of a branch would cross that slowly lumbering vehicle, the swarm would rise and bumble around distractedly for a moment before settling down again. They fairly made a nimbus of darkness.

After we had made camp we saw a number of Masai warriors hovering about the opposite bank, but they did not venture across. Some of their women did, however, and came cheerfully into camp. These most interesting people are worth more than a casual word, so I shall reserve my observations on them until a later chapter. One of our porters, a big Baganda named Sabakaki, was suffering severely from pains in the chest that subsequently developed into pleurisy. From the Masai women we tried to buy some of the milk they carried in gourds. At 


\section{AFRICAN CAMP FIRES}

first they seemed not averse, but as soon as they realized the milk was not for our own consumption, they turned their backs on poor Sabakaki and refused to have anything more to do with us.

These Masai are very difficult to trade with. Their only willing barter is done in sheep. These they seem to consider legitimate objects of commerce.

A short distance from our camp stood three whitewashed round houses with thatched, conical roofs, property of a trader named Agate. He was away at the time of our visit.

After an early morning but vain attempt to get Billy a shot at a lion* we set out for our distant blue mountains. The day was a journey over plains of great variegation. At times they were covered with thin scrub; at others with small groves; or again they were open and grassy. Always they undulated gently, so from their tops one never saw as far as he thought he was going to see. As landmark we steered by a good-sized butte named Donya Rasha.

Memba Sasa and I marched ahead on foot. In this thin scrub we got glimpses of many beasts. At one time we were within fifty yards of a band of magnificent eland. By fleeting glimpses we saw also many wildebeeste and zebra, with occasionally one of the smaller grass antelope. Finally, in an open "See "The Land of Footprints." 


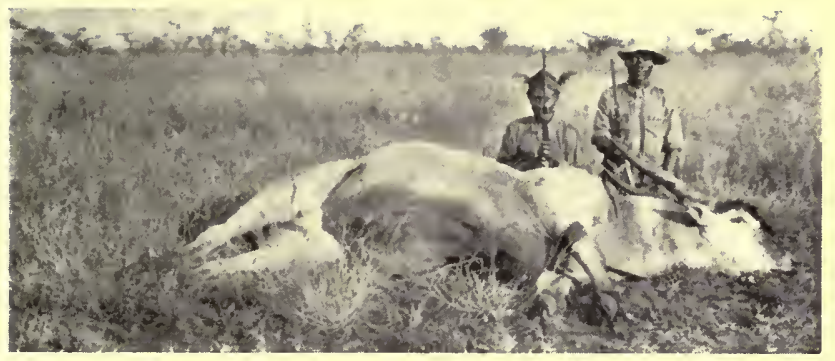

The Eland

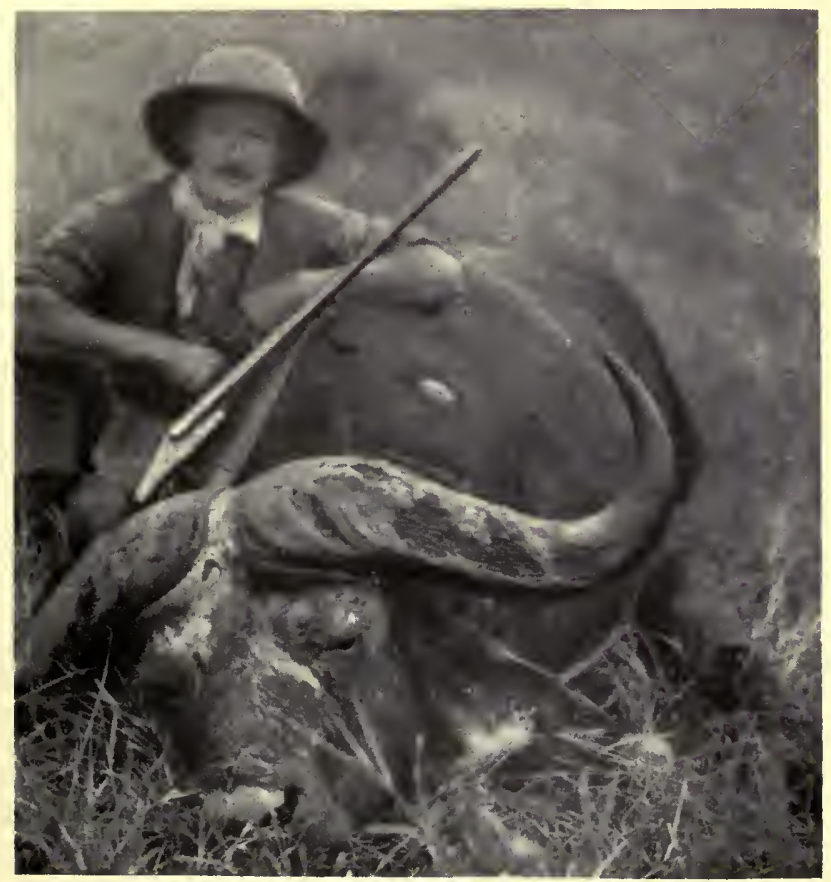

Cape Buffalo 


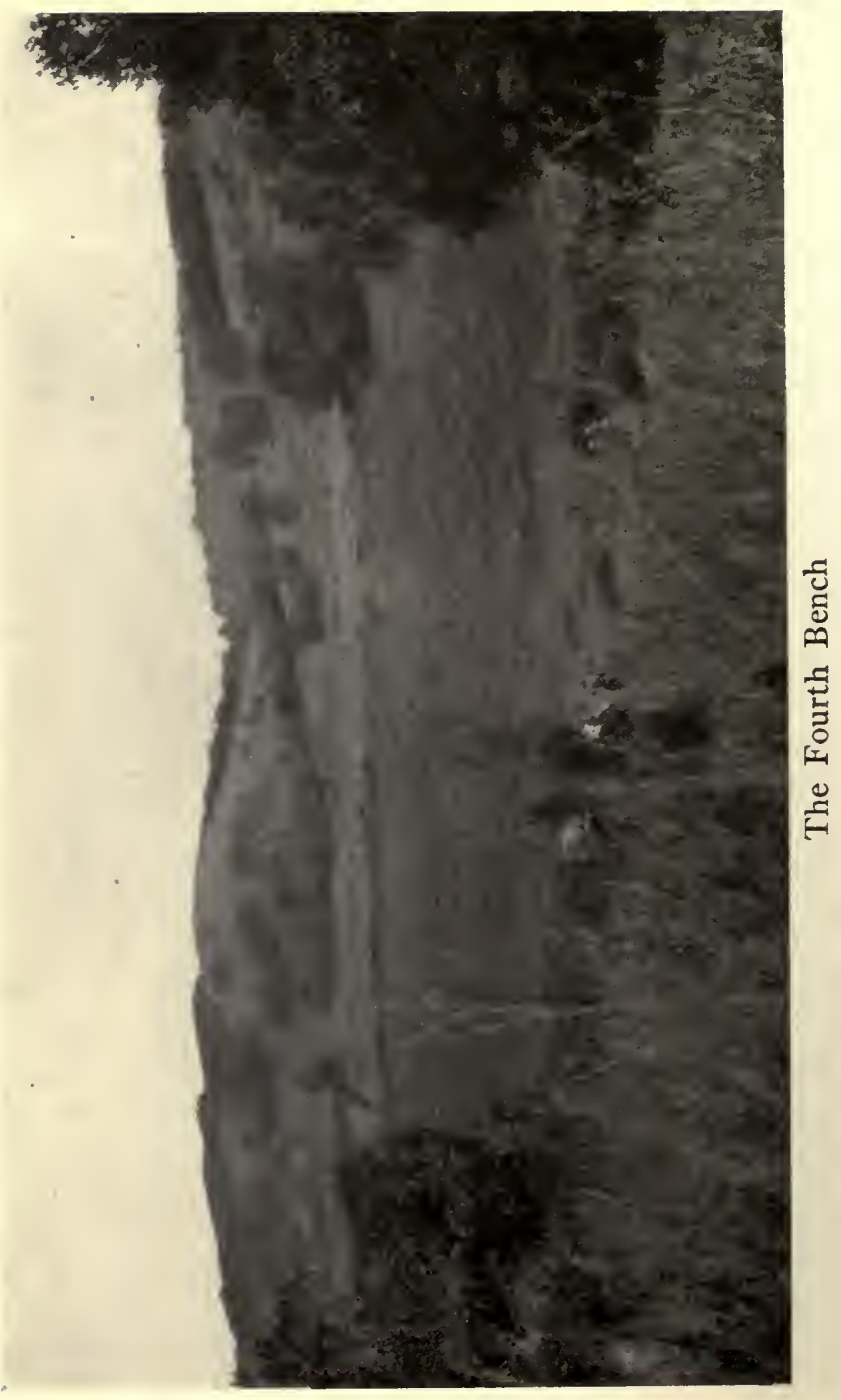




\section{THE SOUTHERN GUASO NYERO}

glade we caught sight of something tawny showing in the middle of a bush. It was too high off the ground to be a buck. We sneaked nearer. At fifty yards we came to a halt, still puzzled. Judging by its height and colour, it should be a lion, but try as we would, we could not make out what part of his anatomy was thus visible. At last I made up my mind to give him a shot from the Springfield, with the .405 handy. At the shot the tawny patch heaved and lay still. We manœuvred cautiously, and found we had killed stone dead not a lion, but a Bohur reed buck lying atop an anthill concealed in the middle of the bush. This accounted for its height above the ground. As it happened, I very much wanted one of these animals as a specimen; so everybody was satisfied.

Shortly after, attracted by a great concourse of carrion birds, both on trees and in the air, we penetrated a thicket to come upon a full-grown giraffe killed by lions. The claw marks and other indications were indubitable. The carcass had been partly eaten; but was rapidly vanishing under the attacks of the birds.

Just before noon we passed Donya Rasha and emerged on the open plains. Here I caught sight of a Roberts' gazelle, a new species to me, and started alone in pursuit. They, as usual, trotted 


\section{AFRICAN CAMP FIRES}

over the nearest rise; so with due precautions I followed after. At the top of that rise I lay still in astonishment. Before me marched solemnly an unbroken single file of game, reaching literally to my limit of vision in both directions. They came over the land swell a mile to my left, and they were disappearing over another land swell a mile and a half to my right. It was rigidly single file, except for the young; the nose of one beast fairly touching the tail of the one ahead, and it plodded along at a businesslike walk. There were but three species represented, the gnu, the zebra, and the hartebeeste. I did not see the head of the procession, for it had gone from sight before I arrived; nor did I ever see the tail of it either, for the safari appearing inopportunely broke its continuance. But I saw two miles and a half, solid, of big game. It was a great and formal trek, probably to new pastures.

Then I turned my attention to the Roberts' gazelle, and my good luck downed a specimen at 273 yards. This with the Bohur reed buck, made the second new species for the day. Our luck was not yet over, however. We had proceeded but a few miles when Kongoni discovered a herd of topi. The safari immediately lay down, while I went ahead. There was little cover, and I had a very hard time to get within range, especially as a dozen zebras kept 


\section{THE SOUTHERN GUASO NYERO}

grazing across the line of my stalks. The topi themselves were very uneasy, crossing and recrossing and looking doubtfully in my direction. I had a number of chances at small bucks, but refused them in my desire to get a shot at the big leader of the herd. Finally he separated from the rest and faced in my direction at just 268 yards. At the shot he fell dead.

For the first time we had an opportunity to admire the wonderful pelt. It is beautiful in quality, plum colour, with iridescent lights and wavy "water marks" changing to pearl colour on the four quarters, with black legs. We were both struck with the gorgeousness of a topi motor-rug made of three skins, with these pearl spots as accents in the corners. To our ambitions and hopes we added more topi.

Our journey to the Naróssara River lasted three days in all. We gained an outlying spur of the blue mountains, and skirted their base. The usual varied foothill country led us through defiles, over ridges, and by charming groves. We began to see Masai cattle in great herds. The gentle humpbacked beasts were held in close formation by herders afoot, tall, lithe young savages with spears. In the distance and through the heat haze the beasts shimmered strangely, their glossy reds and whites and blacks blending together. In this country of wide ex- 


\section{AFRICAN CAMP FIRES}

panses and clear air we could thus often make out a very far-off herd simply as a speck of rich colour against the boundless rolling plains.

Here we saw a good variety of game. Zebras of course, and hartebeeste; the Robert's gazelle, a few topi, a good many of the gnu or wildebeeste discovered by and named after Roosevelt; a few giraffes, klipspringer on the rocky buttes, cheetah, and the usual jackals, hyenas, etc. I killed one very old zebra. So ancient was he that his teeth had worn down to the level of the gums, which seemed fairly on the point of closing over. Nevertheless he was still fat and sleek. He could not much longer have continued to crop the grass. Such extreme age in wild animals is, in Africa at least, most remarkable; for generally they meet violent deaths while still in their prime.

About three o'clock of the third afternoon we came in sight of a long line of forest trees running down parallel with the nearest mountain ranges. These marked the course of the Naróssara; and by four o'clock we were descending the last slope. 


\section{XXXVIII \\ THE LOWER BENCHES}

7 HE Naróssara is really only about creek size, 1 but as it flows the year around it merits the title of river. It rises in the junction of a long spur with the main ranges, cuts straight across a wide inward bend of the mountains, joins them again, plunges down a deep and tremendous cañon to the level of a second bench below great cliffs, meanders peacefully in flowery meadows and delightful glades for some miles, and then once more, and, most unexpectedly, drops eighteen hundred feet by waterfall and precipitous cascade to join the Southern Guaso Nyero. The country around this junction is some of the roughest I saw in Africa.

We camped at the spot where the river ran at about its maximum distance from the mountains. Our tents were pitched beneath the shade of tall and refreshing trees.

A number of Masai women visited us, laughing and joking with Billy in their quizzically humorous fashion. About as we were sitting down at table 


\section{AFRICAN CAMP FIRES}

an Englishman wandered out of the greenery and approached. He was a small man, with a tremendous red beard; wore loose garments and tennis shoes; and strolled up, his hands in his pockets and smoking a cigarette. This was V., a man of whom we had heard. A member of a historical family, officer in a crack English regiment, he had resigned everything to come into this wild country. Here he had built a "boma," or enclosed compound, and engaged himself in acquiring Masai sheep in exchange for beads, wire, and cloth. Obviously the profits of such transactions could not be the temptation. He liked the life, and he liked his position of influence with these proud and savage people. Strangely enough, he cared little for the sporting possibilities of the country, though of course he did a little occasional shooting; but was quite content with his trading, his growing knowledge of and intimacy with the Masai, and his occasional tremendous journeys. To the casual and infrequent stranger his attitude was reported most uncertain.

We invited him to tea, which he accepted, and we fell into conversation. He and Cuninghame were already old acquaintances. The man, I found, was shy about talking of the things that interested him; but as they most decidedly interested us also we managed to convey an impression of our sincerity. There- 


\section{THE LOWER BENCHES}

after he was most friendly. His helpfulness, kindness, and courtesy could not have been bettered. He lent us his own boy as guide down through the cañons of the Naróssara to the lower benches, where we hoped to find kudu; he offered store room to such of our supplies as we intended holding in reserve; he sent us sheep and eggs as a welcome variation of our game diet; and in addition he gave us Masai implements and ornaments we could not possibly have acquired in any other way. It is impossible to buy the personal belongings of this proud and independent people at any price. The price of a spear ordinarily runs about two rupees' worth, when one trades with any other tribe. I know of a case where a Masai was offered fifty rupees for his weapon, but refused scornfully. V. acquired these things through friendship; and after we had gained his, he was most generous with them. Thus he presented us with a thing almost impossible to get and seen rarely outside of museums - the Masai war bonnet made of the mane of a lion. It is in shape and appearance, though not in colour, almost exactly like the grenadier's shako of the last century. In addition to this priceless trophy $V$. also gave us samples of the cattle bells, both wooden and metal, ivory ear ornaments, bead bracelets, steel collars, circumcision knives, sword belts, and 


\section{AFRICAN CAMP FIRES}

other affairs of like value. But I think that the apogee of his kindliness was reached when much later he heard from the native tribes that we were engaged in penetrating the defiles of the higher mountains. Then he sent after us a swift Masai runner bearing to us a bottle of whiskey and a message to the effect that $V$. was afraid we would find it very cold up there! Think of what that meant; turn it well over in your mind, with all the circumstances of distance from supplies, difficulty of transportation and all! We none of us used whiskey in the tropics, so we later returned it with suitable explanation and thanks as being too good to waste.

Next morning, under guidance of our friend's boy, we set out for the lower benches, leaving N'gombe Brown and his outfit to camp indefinitely until we needed him for the return.journey.

The whole lay of the land hereabout is, roughly speaking, in a series of shelves. Back of us were the high mountains - the Fourth Bench; we had been travelling on the plateau of the Loieta - the Third Bench; now we were to penetrate some apparently low hills down an unexpected thousand feet to the Second Bench. This was smaller; perhaps only five miles at its widest. Its outer rim consisted also of low hills concealing a drop of precipitous cliffs. There were no passes nor cañons here - the streams 


\section{THE LOWER BENCHES}

dropped over in waterfalls - and precarious game trails offered the only chance for descent. The First Bench was a mere ledge, a mile or so wide. From it one looked down into the deep gorge of the Southern Guaso Nyero, and across to a tangle of eroded mountains and malpais that filled the eye. Only away in an incredible distance were other blue mountains that marked the farther side of the great Rift Valley.

Our present task was to drop from the Third Bench to the Second. For some distance we followed the Naróssara; then, when it began to drop into its tremendous gorge, we continued along the side hills above it until by means of various "hogs' backs" and tributary cañons we were able to regain its level far below. The going was rough and stony, and hard on the porters; but the scenery was very wild and fine. We met the river bottom again in the pleasantest oval meadow with fine big trees. The mountains quite surrounded us, towering imminent above our heads. Ahead of us the stream broke through between portals that rose the full height of the ranges. We followed it, and found ourselves on the Second Bench.

Here was grass, high grass in which the boys were almost lost to sight. Behind us the ramparts rose sheer and high; and over across the way were some 


\section{AFRICAN CAMP FIRES}

low fifty-foot cliffs that marked a plateau land. Between the plateau and the ranges from which we had descended was a sort of slight flat valley through which meandered the forest trees that marked the stream.

We turned to the right and marched an hour. The river gradually approached the plateau, so leaving between it and the ramparts a considerable plain, and some low foothills. These latter were reported to be one of the feeding grounds of the greater kudu.

We made a most delightful camp at the edge of great trees by the stream. The water flowed at the bottom of a little ravine, precipitous in most places; but with gently sloping banks at the spot we had chosen. It flowed rapidly over clean gravel, with a hurrying, tinkling sound. A broad gravel beach was spread on the hither side of it, like a spacious secret room in the jungle. Here too was a little slope on which to sit, with the thicket all about, the clean, swift little stream below, the high forest arches above, and the inquisitive smaller creatures hovering near. Others had been here before us, the wild things, taking advantage of the easy descent to drinking water - eland, buffalo, leopard, and small bucks. The air was almost cloyingly sweet with a perfume like sage-brush honey. 


\section{THE LOWER BENCHES}

Our first task was to set our boys to work clearing a space; the grass was so high and rank that mere trampling had little effect on it. The Baganda, Sabakaki, we had been compelled to leave with the ox-team. So our twenty-seven had become twentysix.

Next morning Cuninghame and I started out very early with one gunbearer. The direction of the wind compelled us to a two hours' walk before we could begin to hunt. The high grass was soaked with a very heavy dew, and shortly we were as wet as though we had fallen into the river. A number of hornbills and parrots followed us for some distance, but soon left us in peace. We saw the Roberts' gazelle and some hartebeeste.

When we had gained a point of vantage, we turned back and began to work slowly along the base of the mountains. We kept on a general level a hundred feet or so up their slope, just high enough to give us a point of overlook for anything that might stir either in the flat plateau foothills or the plains. We also kept a sharp lookout for signs.

We had proceeded in this manner for an hour when in an opening between two bushes below us, and perhaps five hundred yards away we saw a leopard standing like a statue, head up, a most beautiful spectacle. While we watched her through 


\section{AFRICAN CAMP FIRES}

the glasses, she suddenly dropped flat out of sight. The cause we discovered to be three hartebeeste strolling sociably along, stopping occasionally to snatch a mouthful; but headed always in the direction of the bushes behind which lay the great cat. Much interested, we watched them. They disappeared behind the screen. A sudden flash marked the leopard's spring. Two badly demoralized hartebeeste stampeded out into the open and away; two only. The kill had been made.

We had but the one rifle with us, for we were supposed to be out after kudu only, and were travelling as light as possible. No doubt the Springfield would kill a leopard, if the bullet landed in the right place. We discussed the matter. It ended, of course, in our sneaking down there; I with the Springfield, and Cuninghame with his knife unsheathed. Our precautions and trepidations were wasted. The leopard had carried the hartebeeste bodily some distance, had thrust it under a bush, and had departed. Cuninghame surmised it would return toward evening.

Therefore we continued after kudu. We found old signs, proving that the beasts visited this country, but nothing fresh. We saw, however, the first singsing; some impalla, some klipspringer, and Chanler's reed buck. 


\section{THE LOWER BENCHES}

At evening we made a crafty sneak atop the mesalike foothills to a point overlooking the leopard's kill. We lay here looking the place over inch by inch through our glasses, when an ejaculation of disgust from Kongoni called our attention. There at another spot that confounded beast sat like a house cat watching us cynically. Either we had come too soon, or she had heard us and retired to what she considered a safe distance. There was of course no chance of getting nearer; so I sat down, for a steadier hold, and tried her anyway. At the shot she leaped high in the air, rolled over once, then recovered her feet and streaked off at full speed. Just before disappearing over a slight rise, she stopped to look back. I tried her again. We concluded this shot a miss, as the distance and light were such that only sheer luck could have landed the bullet. However, that luck was with us. Later developments showed that both shots had hit. One cut a foreleg, but without breaking a bone, and the other had hit the paunch. One was at 380 paces and the other at 490 .

We found blood on the trail; and followed it a hundred yards and over a small ridge to a wide patch of high grass. It was now dark; the grass was very high; and the animal probably desperate. The situation did not look good to us, badly armed 


\section{AFRICAN CAMP FIRES}

as we were. So we returned to camp, resolved to take up the trail again in the morning.

Every man in camp turned out next day to help beat the grass. Cuninghame with the .405 , stayed to direct and protect the men; while I, with the Springfield, sat down at the head of the ravine. Soon I could hear the shrieks, rattles, shouts, and whistles of the line of men as they beat through the grass. Small grass bucks and hares bounded past me; birds came whirring by. I sat on a little anthill spying as hard as I could in all directions. Suddenly the beaters fell to dead silence. Guessing this as a signal to me that the beast had been seen, I ran to climb a higher anthill to the left. From there I discerned the animal plainly, sneaking along belly to earth, exactly in the manner of a cat after a sparrow. It was not a woods-leopard; but the plains-leopard, or cheetah, supposed to be a comparatively harmless beast.

At my shot she gave one spring forward and rolled over into the grass. The nearest porters yelled, and rushed in. I ran too, as fast as I could, but was not able to make myself heard above the row. An instant later the beast came to its feet with a savage growl and charged the nearest of the men. She was crippled, and could not move as quickly as usual, but could hobble along faster than 


\section{THE LOWER BENCHES}

her intended victim could run. This was a tall and very conceited Kavirondo. He fled; but ran around in circles, in and out among his excited companions. The cheetah followed him, and him only, with most single-minded purpose.

I dared not shoot while men were in the line of fire even on the other side of the cheetah, for I knew the high-power bullet would at that range go right on through; and I fairly split my throat trying to clear the way. It seemed five minutes, though it was probably only as many seconds, before I got my chance. It was high time. The cheetah had reared to strike the man down.* My shot bowled her over. She jumped to her feet again, made another dash at thoroughly scared Kavirondo, and I killed her just at his coattails.

The cheetahs ordinarily are supposed to be cowards, although their size and power are equal to that of other leopards. Nobody is afraid of them. Yet this particular animal charged with all the ferocity and determination of the lion; and would certainly have killed or badly mauled my man. $\dagger$ To be sure it had been wounded; and had had all night to think about it.

*This is an interesting fact - that she reared to strike instead of springing. fIt must be remembered that this beast had the evening before killed a 350-pound hartebeeste with ease. 


\section{AFRICAN CAMP FIRES}

In the relief from the tension we all burst into shrieks of laughter; all except the near-victim of the scrimmage, who managed only a sickly smile. Our mirth was short. Out from a thicket over a hundred yards away walked one of the men who had been in no way involved in the fight, calmly announcing that he had been shot. We were skeptical, but he turned his back and showed us the bullet hole at the lower edge of the ribs. One of my bullets, after passing through the cheetah, had ricocheted and picked this poor fellow out from the whole of an empty landscape. And this after I had delayed my rescue fairly to the point of danger in order to avoid all chance of hurting some one!

We had no means of telling how deeply the bullet had penetrated; so we reassured the man, and detailed two men to assist him back to camp by easy stages. He did not seem to be suffering much pain, and he had lost little strength.

At camp, however, we found that the wound was deep. Cuninghame generously offered to make a forced march in order to get the boy out to a hospital. By hitting directly across the rough country below the benches it was possible to shorten the journey somewhat, provided V. could persuade the Masai to furnish a guide. The country was a desert, and the water scarce. We lined up our remaining 


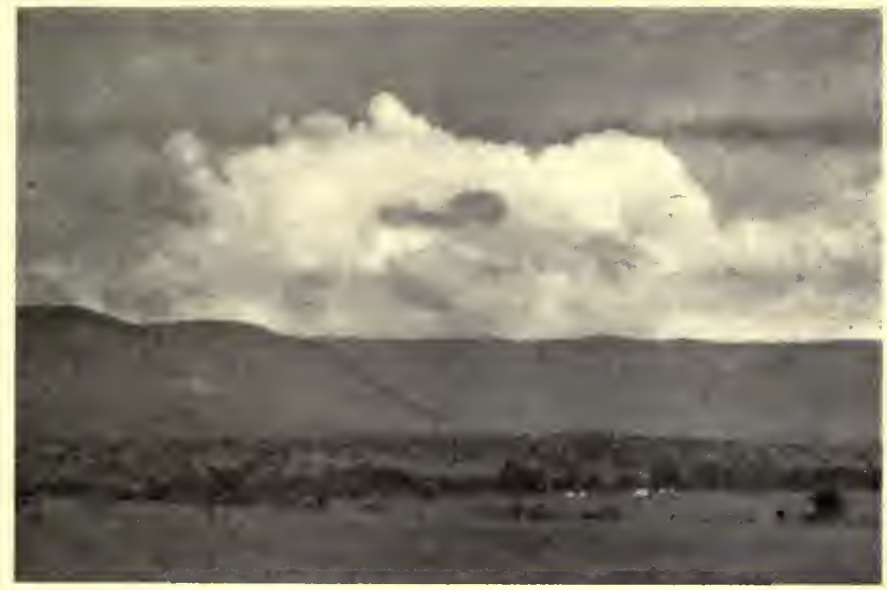

The Valley of Lengeetoto

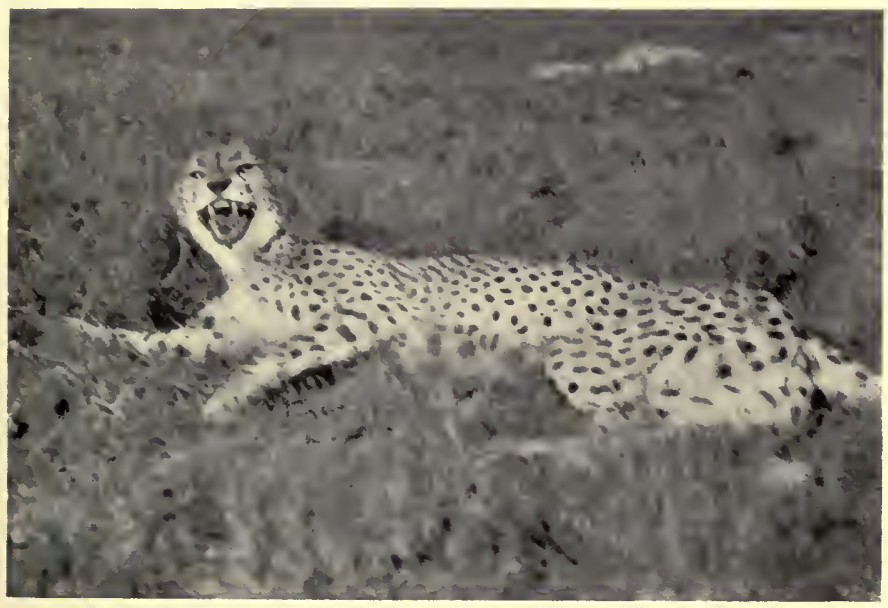

Cheetah 


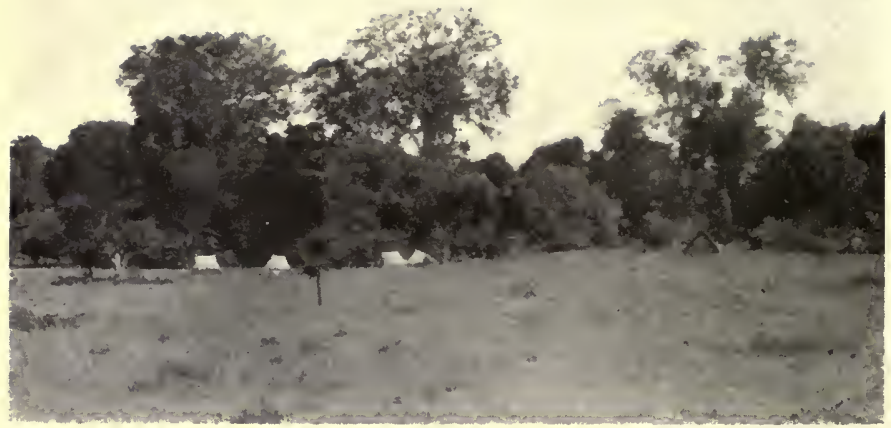

Our camp at the Narossara

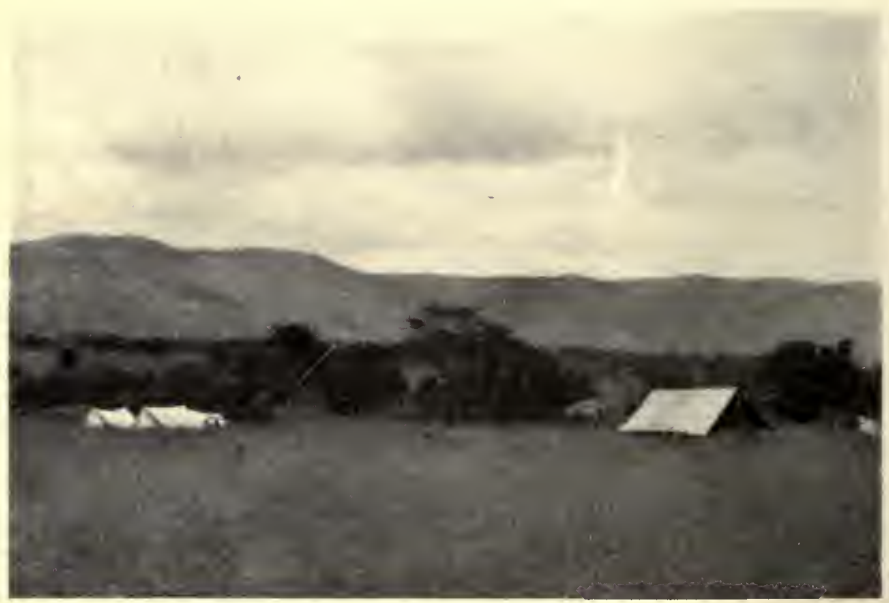

Our camp in Lengeetoto 


\section{THE LOWER BENCHES}

twenty-five men and selected the twelve best and strongest. These we offered a month and a half's extra wages for the trip. We then made a hammock out of one of the ground cloths, and the same afternoon Cuninghame started. I sent with him four of my own men as far as the ox-wagon for the purpose of bringing back more potio. They returned the next afternoon, bringing also a report from Cuninghame that all was well so far, and that he had seen a lion. He made the desert trip without other casualty than the loss of his riding mule; and landed the wounded man in the hospital all right. In spite of Cuninghame's expert care on the journey out, and the best of treatment later, the boy, to my great distress, died eleven days after reaching the hospital. Cuninghame was gone just two weeks.

In the meantime I sent out my best trackers in all directions to look for kudu signs, conceiving this the best method of covering the country rapidly. In this manner I shortly determined that chances were small here; and made up my mind to move down to the edge of the bench where the Naróssara makes its plunge. Before doing so, however, I hunted for and killed a very large eland bull reported by Mavrouki. This beast was not only one of the largest I ever saw, but was in especially fine coat. He stood five feet and six inches high at the shoulder; 


\section{AFRICAN CAMP FIRES}

was nine feet eight inches long, without the tail; and would weigh twenty-five hundred pounds. The men were delighted with this acquisition. I now had thirteen porters, the three gunbearers, the cook, and the two boys. They surrounded each tiny fire with switches full of roasting meat; they cut off great hunks for a stew; they made quantities of biltong, or jerky.

Next day I left Kongoni and one porter at the old camp, loaded my men with what they could carry, and started out. We marched a little over two hours; then found ourselves beneath a lone mimosa tree about a quarter mile from the edge of the bench. At this point the stream drops into a little cañon preparatory to its plunge; and the plateau rises ever so gently to tremendous cliffs. I immediately dispatched the porters back for another load. A fine sing-sing lured me across the river. I did not get the sing sing; but had a good fight with two lions, as narrated elsewhere.*

In this spot we camped a number of days; did a heap of hard climbing and looking; killed another lion out of a band of eight; $\uparrow$ thoroughly determined that we had come at the wrong time for kudu; and decided on another move.

\footnotetext{
*"The Land of Footprints."

t"The Land of Footprints."
} 


\section{THE LOWER BENCHES}

This time our journey lasted five hours, so that our relaying consumed three days. We broke back through the ramparts, by means of another pass we had discovered when looking for kudu, to the Third Bench again. Here we camped in the valley of Lengetoto.

This valley is one of the most beautiful and secluded in this part of Africa. It is shaped like an ellipse, five or six miles long by about three miles wide; and is completely surrounded by mountains. The ramparts of the western side - those forming the walls of the Fourth Bench - rise in sheer rock cliffs, forest crowned. To the east, from which direction we had just come, were high, rounded mountains. At sunrise they cut clear in an outline of milky slate against the sky.

The floor of this ellipse was surfaced in gentle undulations, like the low swells of a summer sea. Between each swell a singing, clear-watered brook leaped and dashed or loitered through its jungle. Into the mountains ran broad upward flung valleys of green grass; and groves of great forest trees marched down cañons and out a short distance into the plains. Everything was fresh and green and cool. We needed blankets at night, and each morning the dew was cool and sparkling, and the sky very blue. Underneath the forest trees of the stream 


\section{AFRICAN CAMP FIRES}

beds, and the cañon, were leafy rooms as small as a closet, or great cathedral aisles. And in the short brush dwelt rhinoceros and impalla; in the jungles were buffalo and elephant; on the plains we saw giraffe, hartebeeste, zebra, duiker; and in the bases of the hills we heard at evening and early morning the roaring of lions.

In this charming spot we lingered eight days; Memba Sasa and I spent most of our time trying to get one of the jungle-dwelling buffalo without his getting us. In this we were finally successful.* Then, as it was about time for Cuninghame to return, we moved back to V.'s boma on the Naróssara; relaying, as usual, the carrying of our effects. At this time I had had to lay off three more men on account of various sorts of illness, so was still more cramped for transportation facilities. As we were breaking camp a lioness leaped to her feet from where she had been lying under a bush. So near was it to camp that I had not my rifle ready. She must have been lying there within two hundred yards of our tents, watching all our activities.

We drew in to V.'s boma a little after two o'clock. The man in charge of our tent did not put in an appearance until next day. Fortunately V. had an extra tent, which he lent us. We camped near the *"The Land of Footprints." 


\section{THE LOWER BENCHES}

river, just outside the edge of the river forest. The big trees sent their branches out over us very far above, while a winding path led us to the banks of the river where was a dingle like an inner room. After dark we sat with $V$. at our little campfire. It was all very beautiful - the skyful of tropical stars, the silhouette of the forest shutting them out, the velvet blackness of the jungle flickering with fireflies, the purer outlines of the hilltops and distant mountains to the left, the porters' tiny fires before the little white tents; and in the distance, from the direction of V.'s boma, the irregular throb of the dance drum and the occasional snatch of barbaric singing borne down on the night wind from where his Wakambas were holding an n'goma.

A pair of ibis that had been ejected when we made camp contributed intermittent outraged and raucous squawks from the tiptop of some neighbouring tree. 


\section{XXXIX}

\section{NOTES ON THE MASAI}

T'T IS in no way my intention to attempt a com1 prehensive description of this unique people. My personal observation is, of course, inadequate to that task, and the numerous careful works on the subject are available to the interested reader.

The southern branch of the race, among whom we were now travelling, are very fine physically. Men close to seven feet in height are not at all uncommon, and the average is well above six. They are strongly and lithely made. Their skins are a red-brown or bronze, generally brought to a high state of polish by liberal anointing. In feature they resemble more the Egyptian or Abyssinian than the negro cast of countenance. The women are tall and well formed, with proud, quaintly quizzical faces. Their expressions and demeanour seem to indicate more independence and initiative than is usual with most savage women, but whether this is actually so or not, I cannot say.

On this imposing and pleasing physical foundation 

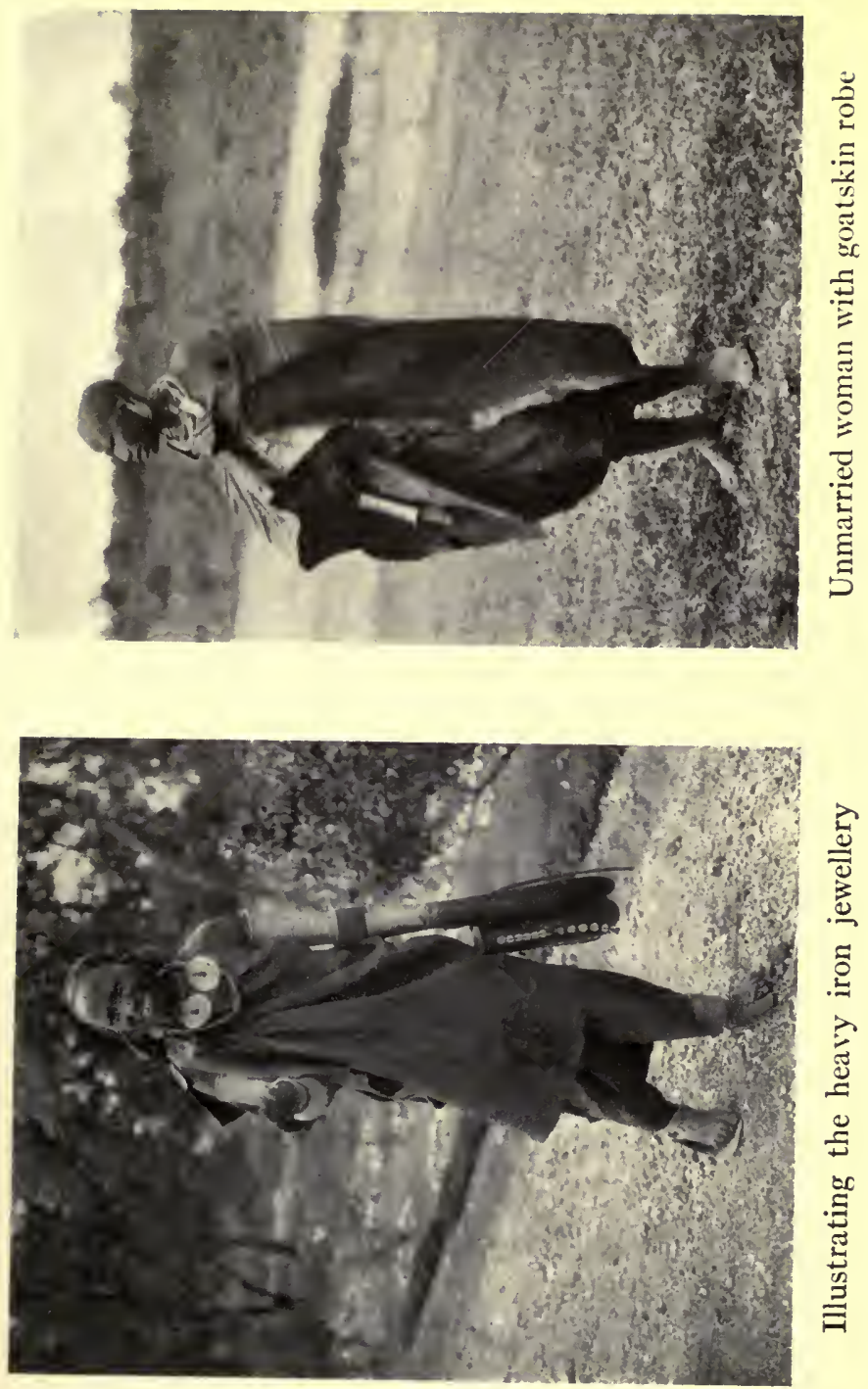


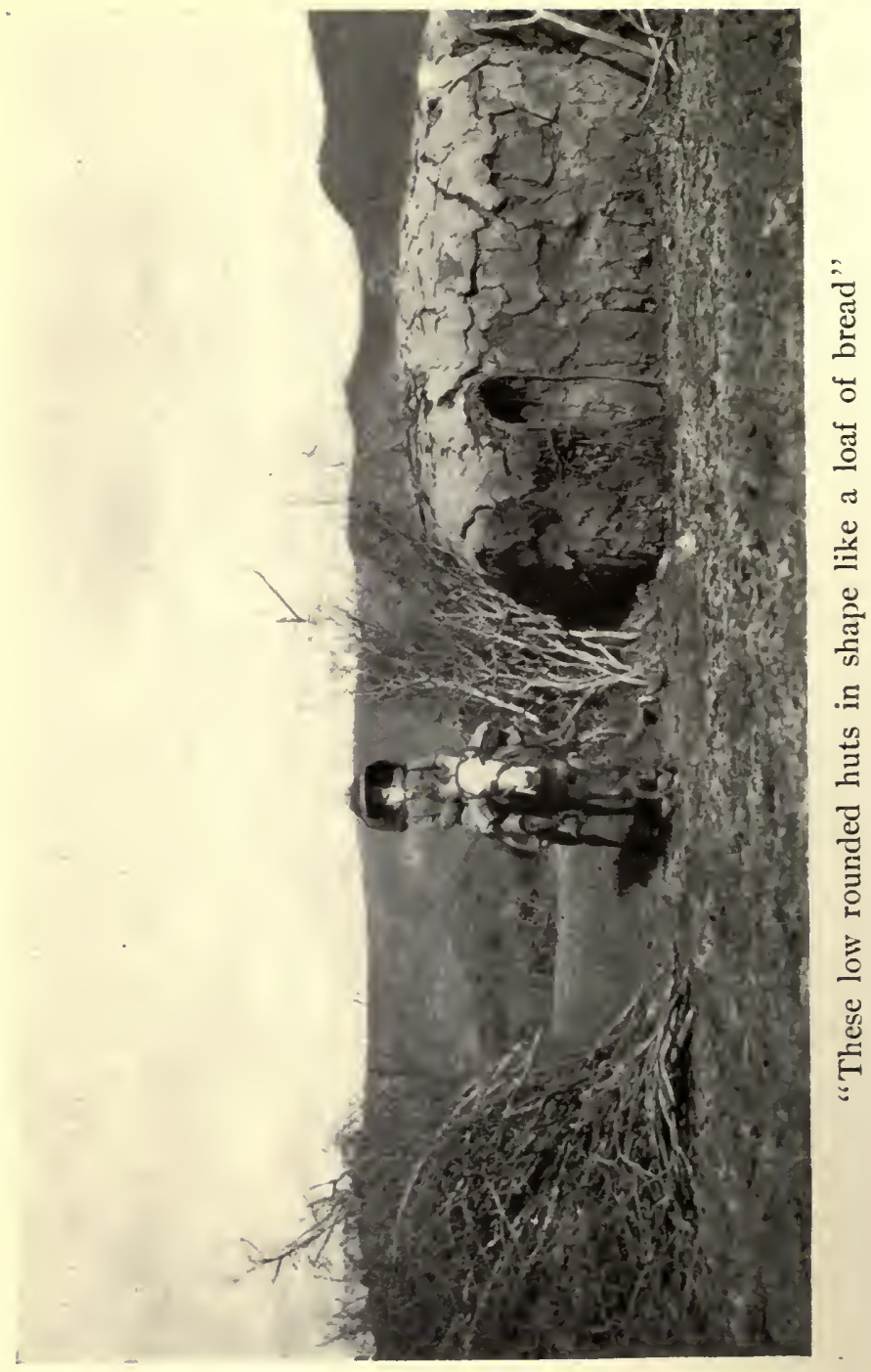




\section{NOTES ON THE MASAI}

your true Masai is content to build a very slight superstructure of ornament. His ear-lobes are always stretched to hang down in long loops, in which small medals, ornaments, decorated blocks of wood, or the like, are inserted. Long heavy ovals of ivory, grooved to accommodate the flesh loop, very finely etched in decorative designs, are occasionally worn as "stretchers." Around the neck is a slender iron collar, and on the arms are one or two glittering bracelets. The sword belt is of leather heavily beaded, with a short dangling fringe of steel beads. Through this the short blade is thrust. When in full-dress the warrior further sports on a garter a hollow iron knee bell, connected with the belt by a string of cowrie shells or beads. Often is added a curious triangular strip of skin fitting over the chest, and reaching about to the waist. A robe or short cloak of short-haired sheepskin is sometimes carried for warmth, but not at all for modesty. The weapons are a long narrow bladed heavy spear, the buffalo hide shield, the short sword, and the war club or runga. The women are always shaven-headed, wear voluminous robes of soft leather; and carry a great weight of heavy wire wound into anklets and stockings, and brought to a high state of polish. So extensive are these decorations that they really form a sort of armour, with breaks only for the elbow and 


\section{AFRICAN CAMP FIRES}

the knee joints. The married women wear also a great outstanding collar.

The Masai are pastoral, and keep immense herds and flocks. Therefore they inhabit the grazing countries; and are nomadic. Their villages are invariably arranged in a wide circle, the low huts of mud and wattles facing in. The spaces between the huts are filled in with thick dense thorn brush, thus enclosing a strong corral, or boma. These villages are called manyattas. They are built by the women in an incredibly brief space of time. Indeed, an overchief stopping two days at one place had been known to cause the construction of a complete village, to serve only for that period. He then moved on, and the manyatta was never used again! Nevertheless these low rounded huts, in shape like a loaf of bread, give a fictitious impression of great strength and permanency. The smooth and hardened mud resembles masonry or concrete work. As a matter of fact it is the thinnest sort of a shell over plaited withes. The single entrance to this compound may be closed by thorn bush so that at night, when the lions are abroad, the Masai and all his herds dwell quite peaceably and safely inside the boma. Twelve to twenty huts constitute a village.

When the grass is fed down the village moves to a new location. There is some regulation to this, 


\section{NOTES ON THE MASAI}

determined by the overchiefs, so that one village does not interfere with another. Beside the few articles of value or of domestic use, the only things carried away from an old village are the strongly woven shield-shaped doors. These are strapped along the flanks of the donkeys, while the other goods rest between. A donkey pack, Masai fashion, is a marvellous affair that would not stay on ten minutes for a white man.

The Masai perform no agriculture whatever, nor will they eat game meat. They have no desire for any of the white man's provisions except sugar. In fact their sole habitual diet is mixed cow's blood and milk - no fruits, no vegetables, no grains, rarely flesh; a striking commentary on extreme vegetarian claims. The blood they obtain by shooting a very sharp-pointed arrow into a neck vein of the cow. After the requisite amount has been drained, the wound is closed and the animal turned into the herd to recuperate. The blood and milk are then shaken together in long gourds. Certainly the race seems to thrive on this strange diet. Only rarely, on ceremonial occasions or when transportation is difficult, do they eat mutton or goat flesh, but never beef.

Of labour then, about a Masai village, it follows 


\section{AFRICAN CAMP FIRES}

that there is practically none. The women build the manyattas; there is no cooking, no tilling of the soil, no searching for wild fruits. The herds have to be watched by day and driven in at the fall of night; that is the task of the boys and the youths who have not gone through with the quadriennial circumcision ceremonies and become El-morani, or warriors. Therefore the grown men are absolutely and completely gentlemen of leisure. In civilization, the less men do the more important they are inclined to think themselves. It is so here. Socially the Masai consider themselves several cuts above anybody else in the country. As social superiority lies mostly in thinking so hard enough - so that the inner belief expresses itself in the outward attitude and manner - the Masai carry it off. Their haughtiness is magnificent. Also they can look as unsmiling and bored as anybody anywhere. Consequently they are either greatly admired; or greatly hated and feared, as the case happens to be, by all the other tribes. The Kikuyu young men frankly ape the customs and ornaments of their powerful neighbours. Even the British Government treats them very gingerly indeed, and allows these economically useless savages a latitude the more agricultural tribes do not enjoy. Yet I submit that any people whose property is in immense herds can more easily 


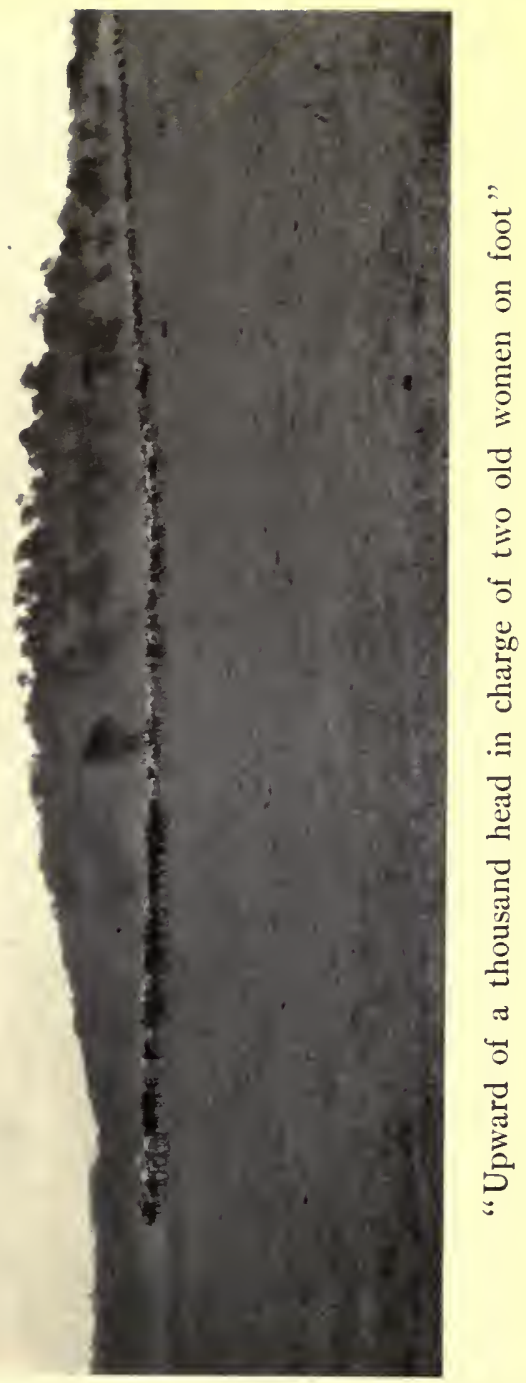




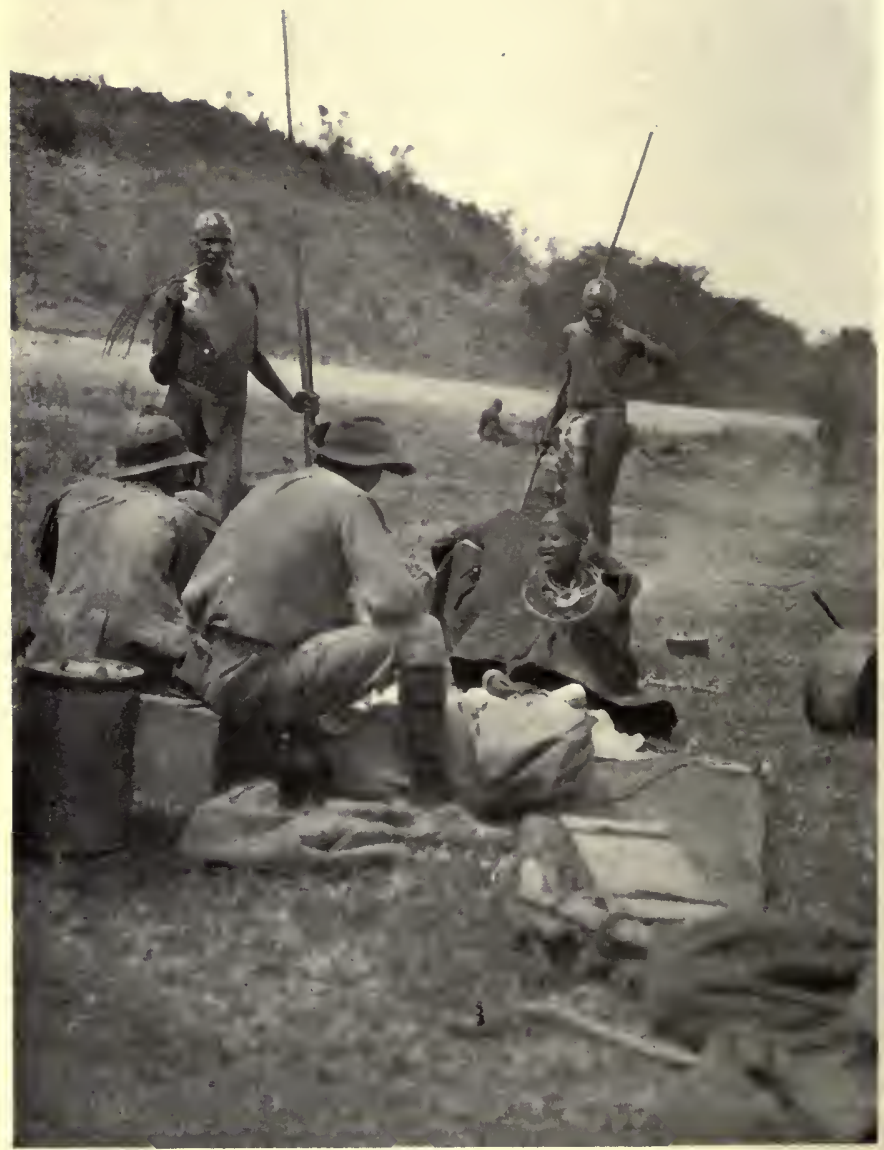

"They visited camp freely, and would sit down for a good lively afternoon of joking" 


\section{NOTES ON THE MASAI}

be brought to terms than those who have nothing so valuable to lose.

As a matter of fact it is said the white man and the Masai have never had it out. When the English, a few years since, were engaged in opening the country they carried on quite a stoutly contested little war with the Wakamba. These people put up so good a fight that the English anticipated a most bitter struggle with the Masai, whose territory lay next beyond. To their surprise the Masai made peace.

"We have watched the war with the Wakamba," they said, in effect, "and we have seen the Wakamba kill a great many of your men. But more of your men came in always; and there were no more Wakamba to come in and take the places of those who were killed. We are not afraid. If we should war with you, we would undoubtedly kill a great many of you, and you would undoubtedly kill a great many of us. But there can be no use in that. We want the ranges for our cattle; you want a road. Let us, then, agree."

The result is that to-day the Masai look upon themselves as an unconquered people, and bear themselves - toward the other tribes - accordingly. The shrewd common sense and observation evidenced above must have convinced them that war now would be hopeless. 


\section{AFRICAN CAMP FIRES}

This acute intelligence is not at all incompatible with the rather bigoted and narrow outlook on life inevitable to a people whose ideals are made up of fancied superiorities over the rest of mankind. Vitness, the feudal aristocracies of the Middle Ages.

With this type the underlying theory of masculine activity is the military. Some outlet for energy was needed, and in war it was found. Even the ordinary necessities of primitive agriculture and of the chase were lacking. The Masai eats neither vegetable, grain, nor wild game. The whole of young manhood, then, can be spent in no better occupation than the pursuit of warlike glory - and cows.

On this rests the peculiar social structure of the people. In perusing the following fragmentary account the reader must first of all divest his mind of what he would, according to white man's standards, consider moral or immoral. Such things must be viewed from the standpoint of the people believing in them. The Masai are moral in the sense that they very rigorously live up to their own customs and creeds. Their women are strictly chaste in the sense that they conduct no affairs outside those permitted within the tribe. No doubt, from the Masai point of view, we are ourselves immoral.

The small boy, as soon as he is big enough to be responsible - and that is very early in life - is 


\section{NOTES ON THE MASAI}

given, in company with others, charge of a flock of sheep. Thence he graduates to the precious herds of cows. He wears little or nothing, is armed with a throwing club, a long stick; or perhaps later a broad-bladed, short-headed spear of a pattern peculiar to boys and young men. His life is thus over the free open hills and veldt, until, somewhere between the ages of eighteen and twenty-one, the year of the circumcision comes. Then he enters on the long ceremonies that initiate him into the warrior class. My knowledge of the details of this subject is limited; for while I had the luck to be in Masailand on the fourth year, such things are not exhibited freely. The curious reader can find more on the subject in other books; but as this is confined to personal experiences I will tell only what I have myself elicited.

The youth's shaved head is allowed to grow its hair. He hangs around his brow a dangling string of bright-coloured bird skins stuffed out in the shape of little cylinders, so that at a short distance they look like curls. For something like a month of probation he wears these; then undergoes the rite. For ten days thereafter he and his companions, their heads daubed with clay and ashes, clad in long black robes, live out in the brush. They have no provision, but are privileged to steal what they need. 


\section{AFRICAN CAMP FIRES}

At the end of the ten days they return to the manyattas. A three-day n'goma, or dance, now completes their transformation to the El-morani class. It finishes by an obscene night dance, in the course of which the new warriors select their partners.

For ten or twelve years these young men are Elmorani. They dwell in a separate manyatta. With them dwell promiscuously all the young unmarried women of the tribe. There is no permanent pairing off, no individual property, no marriage. Nor does this constitute flagrant immorality, difficult as it may be for us to see that fact. The institution, like all national institutions, must have had its origin in a very real need and a very practical expediency. The fighting strength of the tribe must be kept up, and by the young and vigorous stock. On the other hand, every man of military age must be foot free to serve in the constant wars and forays. This institution is the means. And, mind you, unchastity in the form of illicit intercourse outside the manyatta of the El-morani, whether with her own or another tribe, subjects the women to instant death.

The El-morani in full fighting rig are imposing. They are, as I have explained, tall and of fine physique. The cherished and prized weapon is the long, narrow-bladed spear. This is five and six feet long, with a blade over three feet by as many inches, 


\section{NOTES ON THE MASAI}

and with a long, iron shoe. In fact, only a bare handhold of wood is provided. It is of formidable weight, but so well balanced that a flip cast with the wrist will drive it clear through an emeny. A short sword and a heavy headed war club complete the offensive weapons. The shield is of buffalo hide, oval in shape, and decorated with a genuine heraldry, based on genealogy. A circlet of black ostrich feathers in some branches surrounds the face and stands high above the head. In the southern districts the warriors wear two single black ostrich plumes tied one either side the head, and slanting a little backward. They walk with a mincing step so that the two feathers bob gently up and down like the waving of the circus equestrienne's filmy skirts.

Naturally the Masai with the Zulu were the most dreaded of all the tribes of Africa. They were constantly raiding in all directions as far as their sphere of operations could reach, capturing cattle and women as the prizes of war. Now that the white man has put a stop to the ferocious intertribal wars the El-morani are out of a job. The military organization is still carried on as before. What will happen to the morals of the people it would be difficult to say. The twelve years of imposed peace have not been long enough seriously to deteriorate the people; but, inevitably, complete idleness will 


\section{AFRICAN CAMP FIRES}

tell. Either the people must change their ideals and become industrious - which is extremely unlikely or they will degenerate.

As a passing thought, it is a curious and formidable fact that the prohibition of intertribal wars and forays all through East Central Africa has already permitted the population to increase to a point of discomfort. Many of the districts are becoming so crowded as to overflow. What will happen in the long run only time can tell - famine and pestilence probably. Only famine and pestilence are weakening things; while war at least hardens a nation's fibre. This is not necessarily an argument for war. Only everywhere in the world the white man seems with the best of intentions to be upsetting natural balances without substituting for them. We are better at preventing things than causing them.

At the age of thirty, or thereabout, the Elmorani becomes an Elder. He may now drink and smoke, vices that in the Spartan days of his military service were rigourously denied him. He may also take a wife or wives, according to his means, and keep herds of cattle. His wives he purchases from their parents, the usual medium of payment being cows or sheep. The young women who have been living in the El-morani village are considered quite as desirable as the young virgins. If there are 


\section{NOTES ON THE MASAI}

children, these are taken over by the husband. They are considered rather a recommendation than a detriment, for they prove the girl is fruitful.

Relieved of all responsibility the ex-warrior now has full leisure to be a gentleman. He drinks a fermented liquor made from milk; he takes snuff or smokes the rank native tobacco; he conducts interminable diplomatic negotiations; he oversees minutely the forms of ceremonials; he helps shape the policies of his manyatta, and he gives his attention to the accumulation of cows.

The cow is the one thing that arouses the Masai's full energies. He will undertake any journey, any task, any danger, provided the reward therefor is horned cattle. And a cow is the one thing he will on no account trade, sell or destroy. A very few of them he milks, and a very few of them he periodically bleeds; but the majority, to the numbers of thousands upon thousands, live uselessly until they die of old age. They are branded, generally on the flanks or ribs, with strange large brands, and are so constantly handled that they are tamer and more gentle than sheep. I have seen upward of a thousand head in sole charge of two old women on foot. These ancient dames drove the beasts in a long file to water, then turned them quite easily and drove them back again. Opposite our camp they 


\section{AFRICAN CAMP FIRES}

halted their charges and came to make us a long visit. The cattle stood in their tracks until the call was over; not one offered even to stray off the baked earth in search of grasses.

The Masai cattle king knows his property individually. Each beast has its name. Some of the wealthier are worth in cattle, at settler's prices, close to a hundred thousand dollars. They are men of importance in their own council huts, but they lack many things dear to the savage heart simply because they are unwilling to part with a single head of stock in order to procure them.

In the old days forays and raids tended more or less to keep the stock down. Since the White Man's Peace the herds are increasing. In the country between the Mau Escarpment and the Naróssara Mountains we found the feed eaten down to the earth two months before the next rainy season. In the meantime the few settlers are hard put to it to buy cattle at any price wherewith to stock their new farms. The situation is an anomaly which probably cannot continue. Some check will have eventually to be devised, either limiting the cattle, or compelling an equitable sale of the surplus. Certainly the present situation represents a sad economic waste - of the energies of a fine race destined to rust away, and of the lives of tens of thousands of 


\section{NOTES ON THE MASAI}

valuable beasts brought into existence only to die of old age. If these matchless herders and cattle breeders could be brought into relation with the world's markets everybody would be the better.

Beside his sacred cattle the Masai raises also lesser herds of the hairy sheep of the country. These he uses for himself only on the rare occasions of solitary forced marches away from his herds, or at the times of ceremony. Their real use is as a trading medium - for more cattle! Certain white men and Somalis conduct regular trading expeditions into Masailand, bringing in small herds of cows bought with trade goods from the other tribes. These they barter with the Masai for sheep. In Masai estimation a cow is the most valuable thing on earth, while a sheep is only a medium of exchange. With such notions it is easy to see that the white man can make an advantageous exchange, in spite of the Masai's well-known shrewdness at a bargain. Each side is satisfied. There remains only to find a market for the sheep - an easy matter. A small herd of cows will in the long run bring quite a decent profit.

The Masai has very little use for white man's products. He will trade for squares of cloth, beads of certain kinds and in a limited quantity, brass and iron wire of heavy gauge, blankets and sugar. That, 


\section{AFRICAN CAMP FIRES}

barring occasional personal idiosyncrasy, is about all. For these things he will pay also in sheep. Masai curios are particularly difficult to get hold of. I rather like them for their independence in that respect. I certainly should refuse to sell my tennis shoes from my feet merely because some casual Chinaman happened to admire them!

The women seem to occupy a position quite satisfactory to themselves. To be sure they do the work; but there is not much work! They appear to be well treated; at least they are always in good spirits, laughing and joking with each other, and always ready with quick repartee to remarks flung at them by the safari boys. They visited camp freely, and would sit down for a good lively afternoon of joking. Their expressions were quizzical with a sly intelligent humour. In spite of the apparent unabashed freedom of their deportment they always behaved with the utmost circumspection; nor did our boys ever attempt any familiarity. The unobtrusive lounging presence in the background of two warriors with long spears may have had something to do with this.

The Masai government is centred in an overlord or king. His orders seem to be implicitly obeyed. The present king I do not know, as the old king, Lenani, has just died at an advanced age. In 


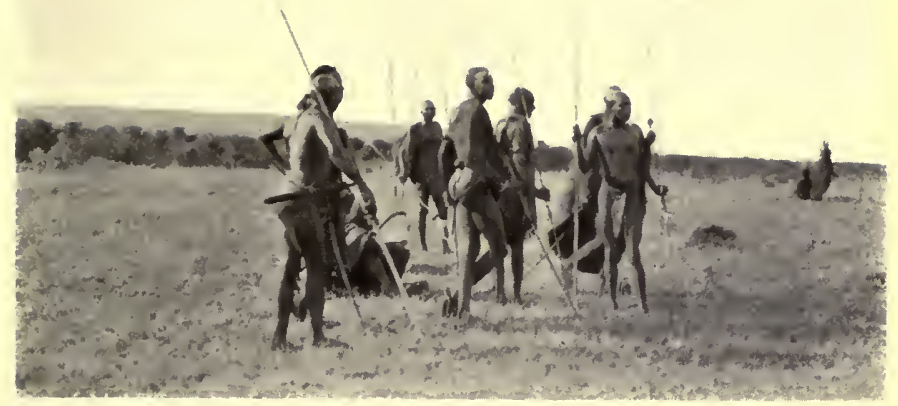

Warriors

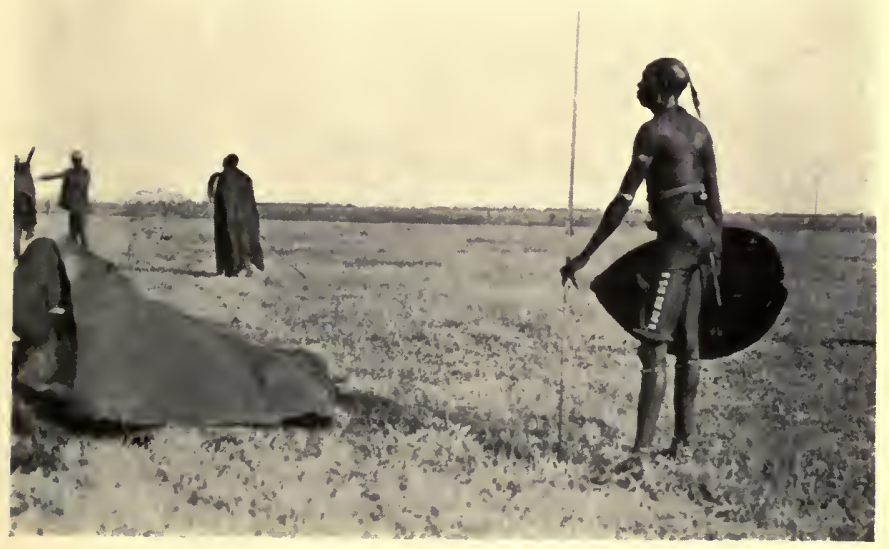

"The southern branch of the race - are very fine physically" 


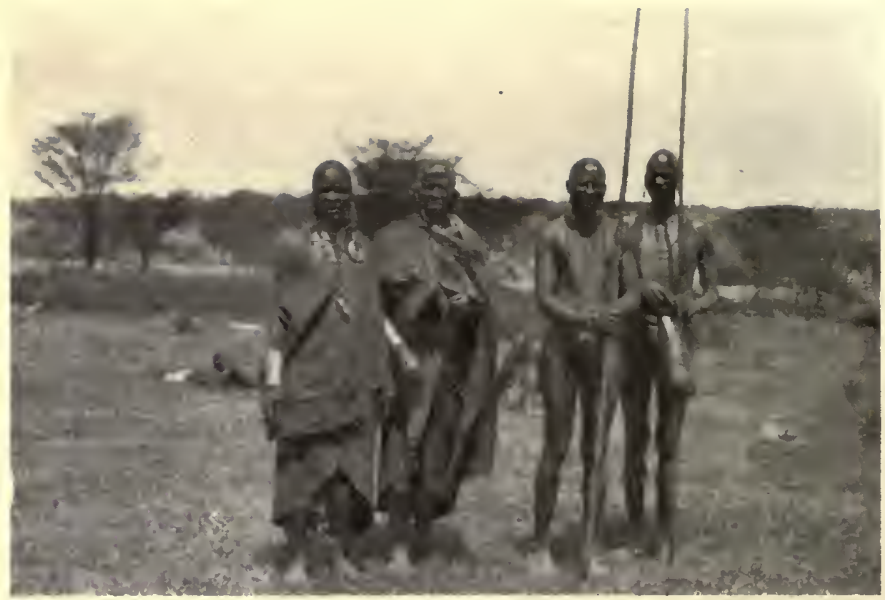

Masai men and women

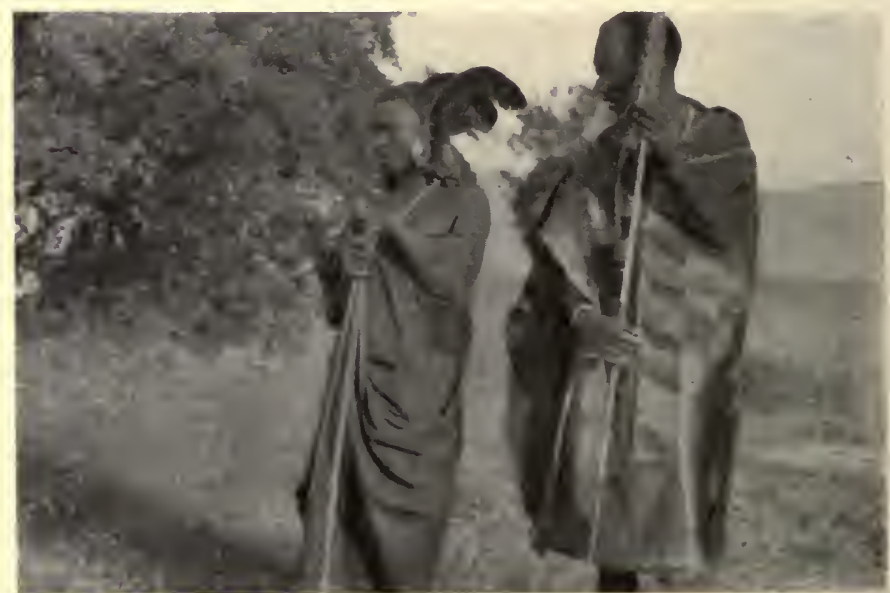

"In the southern districts the warriors wear two single black ostrich feathers" 


\section{NOTES ON THE MASAI}

former days the traveller on entering Masailand was met by a sub-chief. This man planted his long spear upright in the ground, and the intending traveller flung over it coils of the heavy wire. A very generous traveller who completely covered the spear then had no more trouble. One less lavish was likely to be held up for further impositions as he penetrated the country. This tax was called the honga.

The Masai language is one of the most difficult of all the native tongues. In fact, the white man is almost completely unable even to pronounce many of the words. V., who is a "Masai-man" who knows them intimately, and who possesses their confidence, does not pretend to talk with them in their own tongue, but employs the universal Swahili. 


\section{$\mathrm{XL}$}

\section{THROUGH THE ENCHANTED FOREST}

$\mathbf{W}^{\mathrm{E}}$ waited at V.'s boma three days, waiting for Cuninghame to turn up. He maintained a little force of Wakamba, as the Masai would not take service. The Wakamba are a hunting tribe, using both the spear and the poisoned arrow to kill their game. Their bows are short and powerful, and the arrows exceedingly well fashioned. The poison is made from the wood of a certain fat tree with fruit like gigantic bologna sausages. It is cut fine, boiled, and the product evaporated away until only a black sticky substance remains. Into this the point of the arrow is dipped; and the head is then protected until required by a narrow strip of buckskin wound around and around it. I have never witnessed the effects of this poison; but $\mathrm{V}$. told me he had seen an eland die in twenty-two minutes from so slight a wound in the shoulder that it ran barely a hundred yards before stopping. The poison more or less loses its efficiency, however, after the sticky tarlike substance has dried out. 


\section{THROUGH THE ENCHANTED FOREST}

I offered a half rupee as a prize for an archery competition, for I was curious to get a line on their marksmanship. The bull's-eye was a piece of typewriter paper* at thirty paces. This they managed to puncture only once out of fifteen tries; though they never missed it very widely. V. seemed quite put out at this poor showing, so I suppose they can ordinarily do better; but I imagine they are a good deal like our hunting Indians, poor shots but very skilful at stalking close to a beast.

Our missing porter, with the tent, was brought in next afternoon by Kongoni, who had gone in search of him. The man was a big, strong Kavirondo. $\mathrm{He}$ was sullen, and merely explained that he was "tired." This excuse for a five hours' march after eight days' rest! I fined him eight rupees, which I gave Kongoni and ordered him twenty-five lashes. Six weeks later he did the same trick. Cuninghame alotted him fifty lashes and had him led thereafter by a short rope around the neck. $\dot{\mathrm{He}}$ was probably addicted to opium. This was the only man to be formally kibokoed on the whole trip - a good testimony at once to Cuninghame's management, the discrimination we had used in picking them out, and the settled reputations we had by now acquired.

After Cuninghame's return we prepared to pene-

*8xrol inches. 


\section{AFRICAN CAMP FIRES}

trate straight back through the great rampart of mountains to the south and west.

We crossed the bush-grown plains, and entered a gently rising long cañon flanked on either side by towering ranges that grew higher and higher the farther we proceeded. In the very centre of the mountains, apparently, this cañon ended in a small round valley. There appeared to be no possible exit, save by the way we had come, or over the almost perpendicular ridges a thousand feet or more above. Nevertheless we discovered a narrow ravine that slanted up into the hills to the left. Following it we found ourselves very shortly in a great forest on the side of a mountain. Hanging creepers brushed our faces, tangled vines hung across our view, strange and unexpected openings offered themselves as a means through which we could see a little closer into the heart of mystery. The air was cool and damp and dark. The occasional shafts of sunlight or glimpses of blue sky served merely to accentuate the soft gloom. Save that we climbed always, we could not tell where we were going.

The ascent occupied a little over an hour. Then through the tree trunks and undergrowth we caught the skyline of the crest. When we topped this we took a breath, and prepared ourselves for a corresponding descent. But in a hundred yards we 


\section{THROUGH THE ENCHANTED FOREST}

popped out of the forest to find ourselves on a new level. The Fourth Bench had been attained.

It was a grass country of many low, rounded hills and dipping valleys, with fine isolated oaklike trees here and there in the depressions, and compact, beautiful oaklike groves thrown over the hills like blankets. Well-kept, green, trim, intimate, it should have had church spires and gray roofs in appropriate spots. It was a refreshment to the eye after the great and austere spaces among which we had been dwelling, a repose to the spirit after the alert and dangerous lands. The dark curtained forest seemed, fancifully, an enchantment through which we had gained to this remote smiling land, nearest of all to the blue sky.

We continued south for two days; and then, as the narrative will show, were forced to return. We found it always the same type; pleasant sleepy little valleys winding around and between low hills crowned with soft groves and forests. It was for all the world like northern Surrey, or like some of the liveoak country of California. Only this we soon discovered: in spite of the enchantment of the magic-protecting forest, the upper benches, too, were subject to the spell that lies over all Africa. These apparently little valleys were in reality the matter of an hour's journey to cross; these rounded hills, 


\section{AFRICAN CAMP FIRES}

to all seeming only two good golf strokes from bottom to top, were matters of serious climbing; these compact, squared groves of oaklike trees were actually great forests of giants in which one could lose one's self for days, in which roamed herds of elephant and buffalo. It looked compact because we could see all its constituent elements. As a matter of fact, it was neat and tidy; only we were, as usual, too small for it.

At the end of two hours' fast marching we had made the distance, say, from the clubhouse to the second hole. Then we camped in a genuinely little grove of really small trees overlooking a green valley bordered with wooded hills. The prospect was indescribably delightful; a sort of Sunday-morning landscape of groves and green grass and a feeling of church bells.

Only down the valley, diminished by distance, all afternoon Masai warriors, in twos and threes, trooped by, mincing along so that their two ostrich feathers would bob up and down, their spears held atrail.

We began to realize that we were indeed in a new country when our noon thermometer registered only 66 , and when at sunrise the following morning it stood at 44. To us, after eight months under the equator, this was bitter weather! 


\section{XLI}

\section{NAIOKOTUKU}

TEXT morning we marched on up the beautiful 1 valley through shoulder-high grasses wet with dew. At the end of two hours we came to the limit of Leyeye's knowledge of the country. It would now be necessary to find savage guides.

Accordingly, while we made camp, Cuninghame, with Leyeye as interpreter, departed in search of a Masai village. So tall and rank grew the grass that we had to clear it out as one would clear brushwood in order to make room for our tents.

Several hours later Cuninghame returned. He had found a very large village, but unfortunately the savages were engaged in a big n'goma which could not be interrupted by mere business. However, the chief was coming to make a friendly call. When the n'goma should be finished, he would be delighted to furnish us with anything we might desire.

Almost on the heels of this the chief arrived. $\mathrm{He}$ was a fine old savage, over six feet tall, of well proportioned figure, and with a shrewd, intelligent 


\section{AFRICAN CAMP FIRES}

face. The n'goma had him, to a limited extent, for he stumbled over tent ropes, smiled a bit uncertainly, and slumped down rather suddenly when he had meant to sit. However, he both stumbled, smiled, and slumped with unassailable dignity.

From beneath his goatskin robe he produced a long ornamented gourd from which he offered us a drink of fermented milk. He took our refusal good-naturedly. The gourd must have held a gallon, but he got away with all of its contents in the course of the interview; also several pints of super-sweetened coffee which we doled out to him a little at a time, and which he seemed to appreciate extravagantly.

Through Leyeye we exchanged the compliments of the day, and, after the African custom, told each other how important we were. Our visitor turned out to be none other than the brother of Lenani, the paramount chief of all the Masai. I forget what I was, either the brother of King George or the nephew of Theodore Roosevelt - the only two white men every native has heard of. It may be that both of us were mistaken, but from his evident authority over a very wide district we were inclined to believe our visitor.

We told him we wanted guides through the hills to the southward. He promised them in a most friendly fashion. 


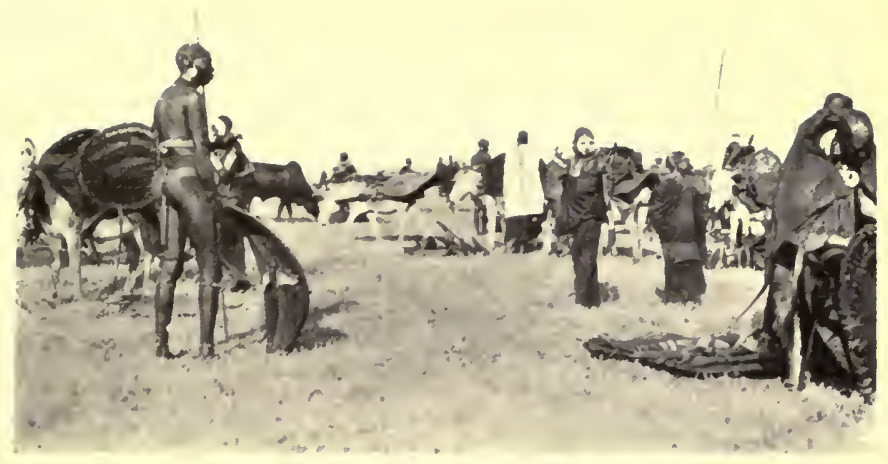

"The girl in the middle ground has painted her face white to indicate travel"

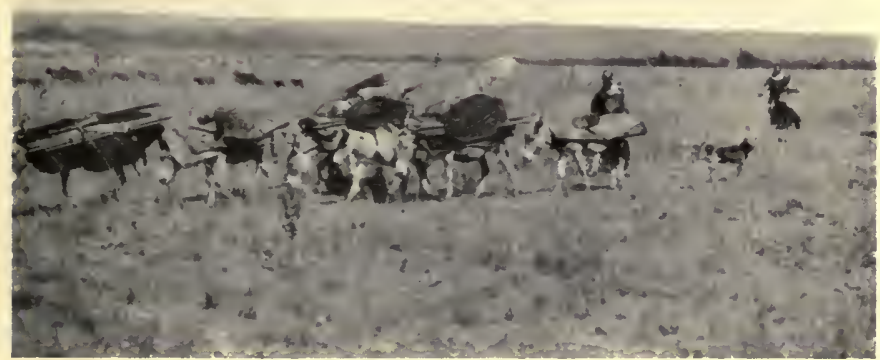

When moving the villages they take with them only the wicker doors 

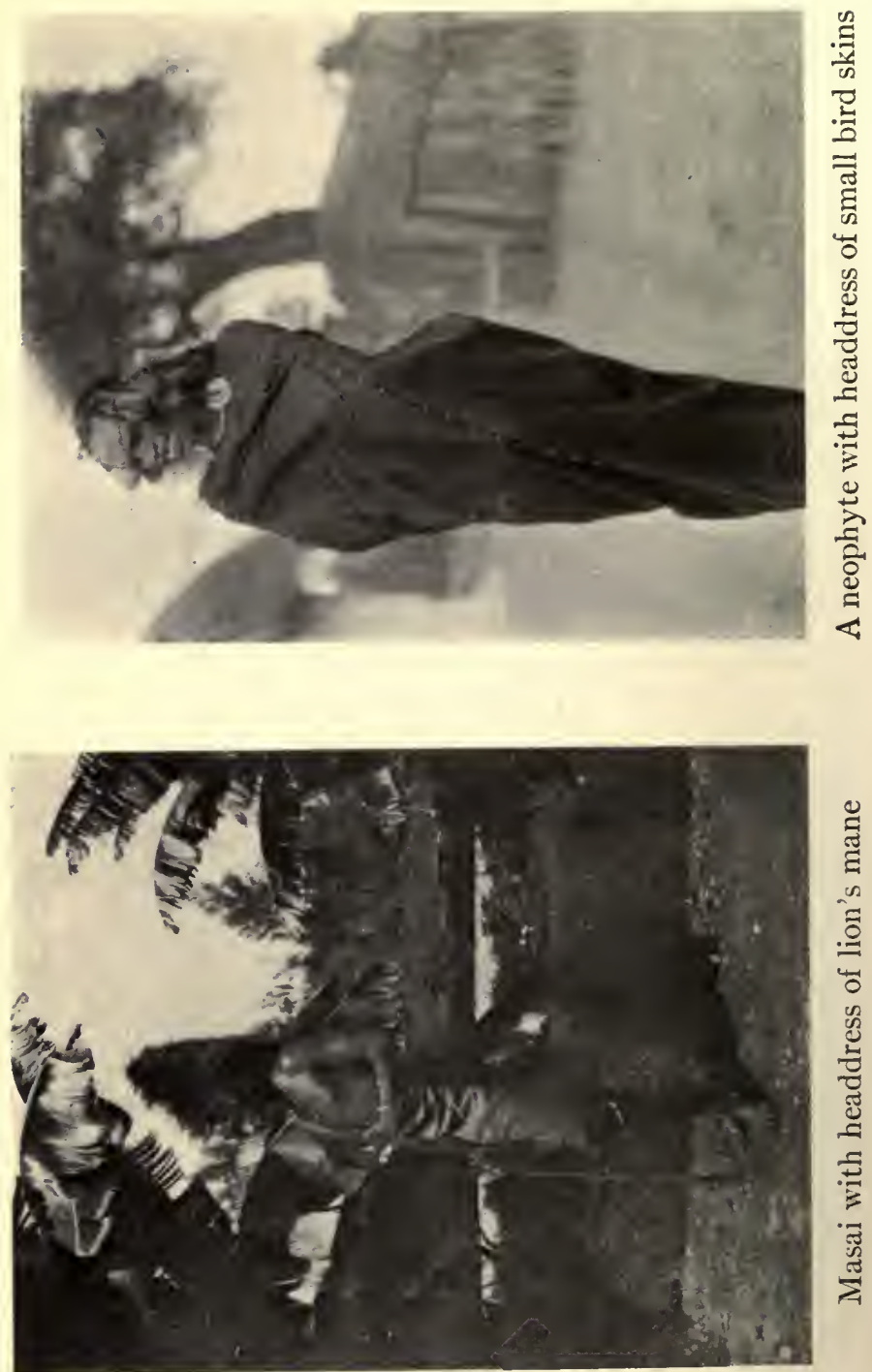


\section{NAIOKOTUKU}

"I do not know the white man," said he. "I live always in these mountains. But my brother Lenani told me ten years ago that some day the white man would come into my country. My brother told me that when the white man came travelling in my country I must treat him well, for the white man is a good friend but a bad enemy. I have remembered my brother Lenani's words, though they were spoken a long time ago. The white man has been very long in coming; but now he is here. Therefore I have brought you milk to-day, and to-morrow I will send you sheep; and later I will send young men who know the hills to take you where you wish to go."

We expressed gratification, and I presented him with a Marble fish knife. The very thin blade and the ingenious manner in which the two halves of the handle folded forward over it pleased him immensely.

"No one but myself shall ever use this knife," said he.

He had no pockets, but he tucked it away in his armpit, clamped the muscles down over it, and apparently forgot it. At least he gave it no further attention, used his hands as usual, but retained it as securely as in a pocket.

"To-morrow," he promised at parting, "very 


\section{AFRICAN CAMP FIRES}

early in the morning, I will send my own son and another man to guide you; and I will send a sheep for your meat."

We arose "very early," packed our few affairs, picked out four porters - and sat down to wait. Our plan was to cruise for five days with as light and mobile an outfit as possible, and then to return for fresh supplies. Billy would take charge of the main camp during our absence. As advisers we left her Abba Ali, Memba Sasa, and Mohamet.

At noon we were still waiting. The possibility of doing a full day's journey was gone, but we thought we might at least make a start. At one o'clock, just as we had about given up hope, the Masai strolled in. They were beautiful, tall, straight youths, finely formed, with proud features and a most graceful carriage. In colour they were as though made of copper bronze, with the same glitter of high lights from their fine-textured skins. Even in this chilly climate they were nearly naked. One carried a spear; the other a bow and arrow.

Joyously we uprose - and sat down again. We had provided an excellent supply of provisions for our guides; but on looking over the lot they discovered nothing, absolutely nothing, that met their ideas.

"What do they want?" we asked Leyeye in despair. 


\section{NAIOKOTUKU}

"They say they will eat nothing but sheep," he reported.

We remembered old Naiokotuku's promise of sending us sheep, sneered cynically at the faith of savages, and grimly set forth to see what we could buy in the surrounding country. But we wronged the old man. Less than a mile from camp we met men driving in as presents not one, but two, sheep. So we abandoned our shopping tour and returned to camp. By the time one of the sheep had been made into mutton it was too late to start. The Masai showed symptoms of desiring to go back to the village for the night. This did not please us. We called them up, and began extravagantly to admire their weapons, begging to examine them. Once we had them in our hands we craftily discoursed as follows:

"These are beautiful weapons, the most beautiful we have ever seen. Since you are going to spend the night in our camp, and since we greatly fear that some of our men might steal these beautiful weapons, we will ourselves guard them for you carefully from theft until morning."

So saying, we deposited them inside the tent. Then we knew we had our Masai safe. They would never dream of leaving while the most cherished of their possessions were in hostage. 


\section{XLII}

\section{SCOUTING IN THE ELEPHANT FOREST}

HERE we were finally off at dawn. It was a very 1 chilly, wet dawn, with the fog so thick that we could see not over ten feet ahead. We had four porters carrying about twenty-five pounds apiece of the bare necessities, Kongoni, and Leyeye. The Masai struck confidently enough through the mist. We crossed neck-deep grass flats - where we were thoroughly soaked - climbed hills through a forest, skirted apparently for miles an immense reed swamp. As usual when travelling strange country in a fog, we experienced that queer feeling of remaining in the same spot while fragments of nearby things are slowly paraded by. When at length the sun's power cleared the mists, we found ourselves in the middle of a forest country of high hills.

Into this forest we now plunged, threading our way here and there where the animal trails would take us, looking always for fresh elephant spoor. It would have been quite impossible to have moved 


\section{SCOUTING IN THE ELEPHANT FOREST}

about in any other fashion. The timber grew on side hills, and was very lofty and impressive; and the tropical undergrowth grew tall, rank and impenetrable. We could proceed only by means of the kind assistance of the elephant, the buffalo and the rhinoceros.

Elephant spoor we found, but none made later than three weeks before. The trails were broad, solid paths through the forest, as ancient and beaten as though they had been in continuous use for years. Unlike the rhino and buffalo trails, they gave us head room and to spare. The great creatures had by sheer might cut their way through the dense, tough growth, leaving twisted, splintered, wrecked jungle, behind them, but no impediment.

By means of these beautiful trails we sneaked quietly, penetrating farther and farther into the jungle. Our little procession of ten made no noise. If we should strike fresh elephant tracks, thus would we hunt them, with all our worldly goods at our backs, so that at night we could camp right on the trail.

The day passed almost without incident. Once a wild crash and a snort told of a rhinoceros, invisible, but very close. We huddled together, our rifles ready, uncertain whether or not the animal would burst from the leafy screen at our very faces. 


\section{AFRICAN CAMP FIRES}

The Masai stood side by side, the long spear poised, the bow bent, fine, tense figures in bronze.

Near sundown we found ourselves by a swift little stream in the bottom of a deep ravine. Here we left the men to make camp, and ourselves climbed a big mountain on the other side. It gave us a look abroad over a wilderness of hills, forested heavily, and a glimpse of the land-fall far away where no white man had ever been. This was as far south as we were destined to get, though at the time we did not know it. Our plan was to push on two days more. Near the top of the ridge we found the unmistakable tracks of the bongo. This is interesting to zoölogists in that it extends the southward range of this rare and shy beast.

Just at dark we regained our camp. It was built California fashion - for the first and last time in Africa: blankets spread on canvas under the open sky and a gipsy fire at our feet, over which I myself cooked our very simple meal. As we were smoking our pipes in sleepy content, Leyeye and the two Masai appeared for a shauri. Said the Masai:

"We have taken you over the country we know. There are elephants there sometimes, but there are no elephants there now. We can take you farther, and if you wish us to do so, we will do so; but we know no more of the country than you do. But 


\section{SCOUTING IN THE ELEPHANT FOREST}

now if we return to the manyatta to-morrow, we can march two hours to where are some Wanderobo; and the Wanderobo know this country and will take you through it. If it pleases you, one of us will go get the Wanderobo, and the other will stay with you to show good faith."

We rolled our eyes at each other in humorous despair. Here at the very beginning of the reconnaissance we had run against the stone wall of African indirectness and procrastination. And just as we thought we had at last settled everything!

"Why," we inquired, "were not the Wanderobo sent at first, instead of yourselves?"

"Because," they replied with truly engaging frankness, "our chief, Naiokotuku, thought that perhaps we might find elephant here in the country we know; and then we should get for ourselves all the presents you would give for finding elephant. But the elephant are not here now; so the Wanderobo will get part of the present."

That was certainly candid. After some further talk we decided there was no help for it; we must return to camp for a new start.

At this decision the Masai brightened. They volunteered to set off early with Leyeye, to push ahead of us rapidly, and to have the Wanderobo in 


\section{AFRICAN CAMP FIRES}

camp by the time we reached there. We concealed somewhat cynical smiles, and agreed.

The early start was made, but when we reached camp we found, not the Wanderobo, but Leyeye and the Masai huddled over a fire. This was exasperating, but we could not say much. After all, the whole matter was no right of ours, but a manifestation of friendship on the part of Naiokotuku. In the early afternoon the sky cleared, and the ambassadors departed, promising faithfully to be back before we slept. We spent the day writing and in gazing at the vivid view of the side hill, the forest, and the distant miniature prospect before us. Finally we discovered what made it in essence so strangely familiar. In vividness and clarity, even in the crudity of its tones, it was exactly like a coloured photograph!

Of course the savages did not return that evening, nor did we really expect them. Just as a matter of form we packed up the next morning, and sat down to wait. Shortly before noon Leyeye and the Masai returned, bringing with them two of the strange, shy, forest hunters.

But by this time we had talked things over thoroughly. The lure of the greater kudu was regaining the strength it had lost by a long series of disappointments. We had not time left for both 

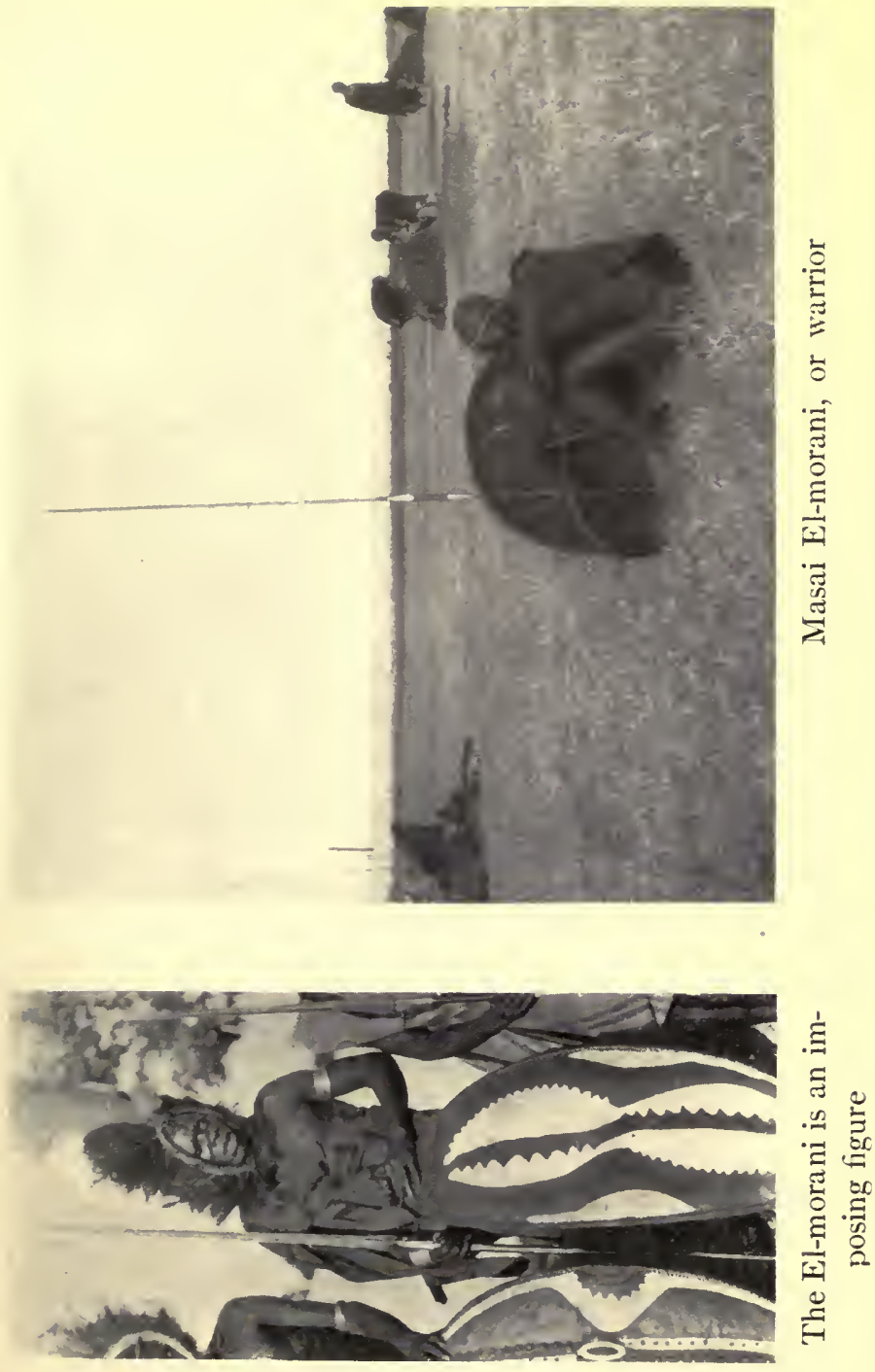


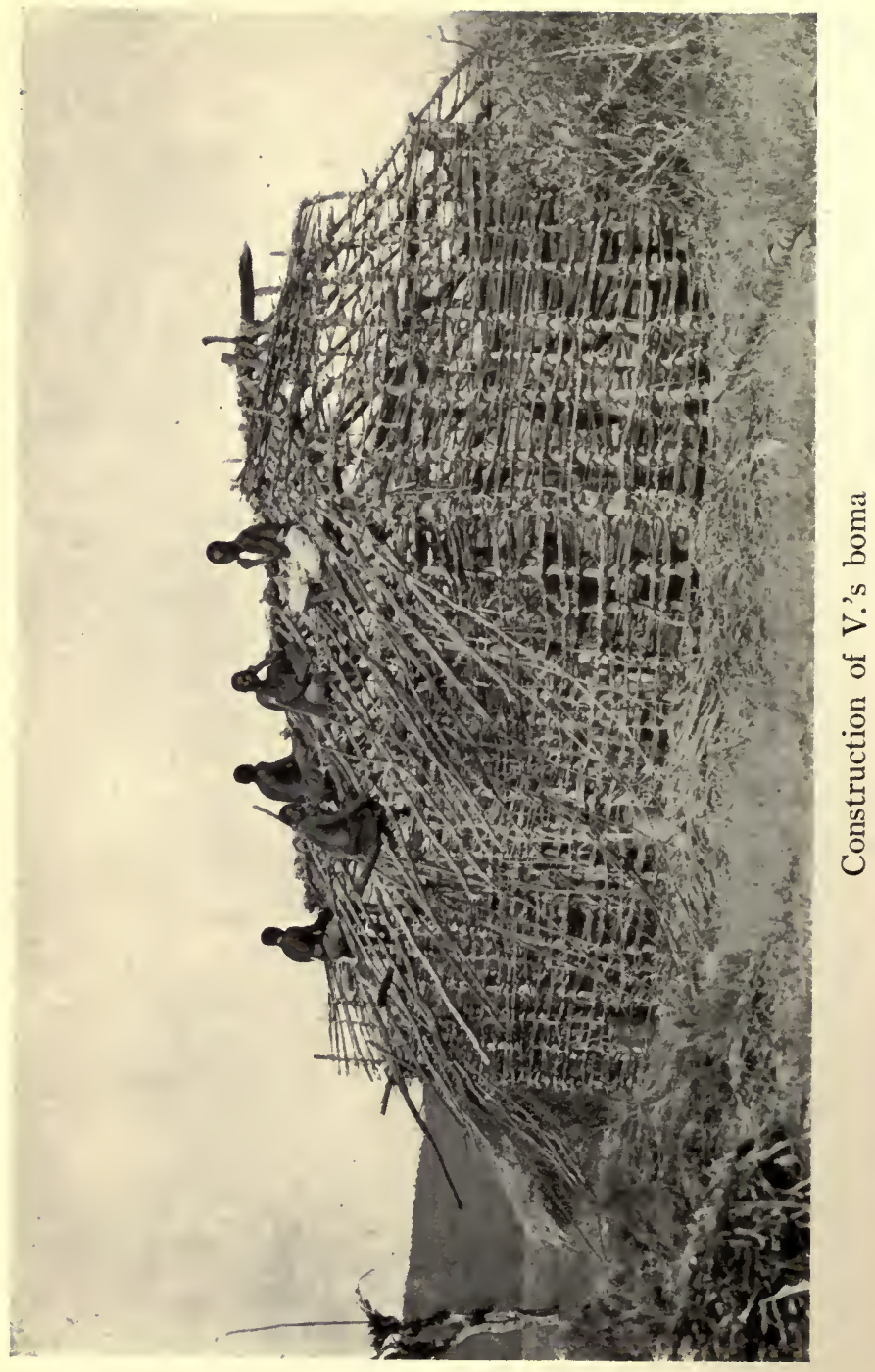




\section{SCOUTING IN THE ELEPHANT FOREST}

a thorough investigation of the forests and a raid in the dry hills of the west after kudu. Mavrouki said he knew of a place where that animal ranged. So we had come to a decision.

We called the Masai and Wanderobo before us. They squatted in a row, their spears planted before them. We sat in canvas chairs. Leyeye, standing, translated. The affair was naturally of the greatest deliberation. In the indirect African manner we began our shauri.

We asked one simple question at a time, dealing with one simple phase of the subject. This phase we treated from several different points of view, in order to be absolutely certain that it was understood. To these questions we received replies in this manner:

Yes, the Wanderobo told us, they knew the forest; they knew how to go about in the forest; they understood how to find their way in the forest. They knew the elephant; they had seen the elephant many times in the forest; they knew where the elephant ranged in the forest - and so on through every piece of information we desired. It is the usual and only sure way of questioning natives.

Thus we learned that the elephant range extended south through the forests for about seven days' travel; that at this time of year the beasts might be 


\section{AFRICAN CAMP FIRES}

anywhere on that range. This confirmed our decision. Then said we to Leyeye:

"Tell the Masai that the bwana m'kubwa is most pleased with them, and that he is pleased with the way they have worked for him, and that he is pleased with the presents they have brought him. Tell them that he has no goods here with him, but that he has sent men back to the boma of bwana Kingozi* for blankets and wire and cloth, and when those men return he will make a good present to these Masai and to Naiokotuku, their chief.

"Tell the Wanderobo that the bwana m'kubwa is pleased with them, and that he thanks them for coming so far to tell him of the elephant, and that he believes they have told him the truth. Tell them the bwana m'kubwa will not fight the elephant now, because he has not the time, but must go to attend to his affairs. But later, when two years have gone, he will make another safari, and will come back to this country, and will again ask these men to lead him out where he can fight the elephant. And in the meantime he will give them rupees with which to pay their hut tax to the Government."

After various compliments the sitting rose. Then we packed up for a few hours' march. In a short time we passed the chief's village. He came out to

*V.'s native name - the Master with the Red Beard. 


\section{SCOUTING IN THE ELEPHANT FOREST}

say good-bye. A copper bronze youth accompanied him, lithe as a leopard.

"My men have told me your words," said he. "I live always in these mountains, and my young men will bring me word when you return. I am glad the white men have come to see me. I shall have the Wanderobo ready to take you to fight the elephant when you return."

He then instructed the young man to accompany us for the purpose of bringing back the presents we had promised. We shook hands in farewell, and so parted from this friendly and powerful chief. 


\section{XLIII}

\section{THE TOPI CAMP}

$\Delta \mathrm{T}$ the next camp we stayed for nearly a week. 1 The country was charming. Mountains surrounded the long ellipse, near one edge of which we had pitched our tents. The ellipse was some ten miles long by four or five wide, and its surface rolled in easy billows to a narrow neck at the lower end. There we could just make out in the far distance a conical hill partly closing the neck. Atop the hill was a Masai manyatta, very tiny, with indistinct crawling red and brown blotches that meant cattle and sheep. Beyond the hill, and through the opening in the ellipse, we could see to another new country of hills and meadows and forest groves. In this clear air they were microscopically distinct. No blue of atmosphere nor shimmer of heat blurred their outlines. They were merely made small.

Our camp was made in the open above a tiny stream. We saw wonderful sunrises and sunsets; and always spread out before us was the sweep of our plains and the unbroken ramparts that hemmed 


\section{THE TOPI CAMP}

us in. From these mountains meandered small stream-ways marked by narrow strips of trees and brush; but the most of the valley was of high green grass. Occasional ant-hills ten feet tall rose conical from the earth; and the country was pleasingly broken and modelled, so that one continually surmounted knolls, low, round ridges, and the like. Of such conditions are surprises made.

The elevation here was some 7,000 feet; so that the nights were cold and the days not too warm. Our men did not fancy this change of weather. A good many of them came down with the fever always latent in their systems, and others suffered with bronchia: colds,

At one time we had down sick eleven men out of our slender total. However, I believe in spite of these surface symptoms, that the cold air did them good. It certainly improved our own appetites and staying power.

In the thirty or forty square miles of our valley were many herds of varied game. We here, for the first time, found the Neuman's hartebeeste. The type at Naróssara, and even in Lengetoto, was the common Coke's hartebeeste, so that between these closely allied species there interposes at this point only the barriers of a climb and a forest. These animals and the zebra were the most plentiful of the 


\section{AFRICAN CAMP FIRES}

game. The zebra were brilliantly white and black, with magnificent coats. Thompson's and Roberts' gazelles were here in considerable numbers, eland, Roosevelt's wildebeeste, giraffe, the smaller grass antelopes, and a fair number of topi. In the hills we saw buffalo signs, several cheetah, and heard many lions.

It had been our first plan that $C$. should return immediately to V.'s boma after supplies, but in view of the abundance of game we decided to wait over a day. We much desired to get four topi; and this seemed a good chance to carry some of them out. Also we wished to decide for certain whether or not the hartebeeste here was really of the Neuman variety.

We had great luck. Over the very first hill from camp we came upon a herd of about a dozen topi, feeding on a hill across the way. I knocked down the first one standing at just 250 paces. The herd then split and broke to right and left. By shooting very carefully and steadily I managed to kill three more before they were out of range. The last shot was at 325 paces. In all I fired seven shots, and hit six times. This was the best shooting I did in Africa - or anywhere else - and is a first-rate argument for the Springfield and the high velocity, sharppointed bullet. 


\section{THE TOPI CAMP}

Overjoyed at our luck in collecting these animals so promptly, so near camp, and at a time so very propitious for handling the trophies, we set to the job of skinning and cutting up. The able-bodied men all came out from camp to carry in the meat. They appeared grinning broadly, for they had had no meat since leaving the Naróssara. Cuninghame and I saw matters well under way, and then went on to where I had seen a cheetah the day before. Hardly were we out of sight when two lions sauntered over the hill and proceeded to appropriate the meat! The two men in charge promptly withdrew. A moment later a dozen porters on their way out from camp topped the hill and began to yell at the lions. The latter then slowly and reluctantly retreated.

We were very sorry we had not stayed. The valley seemed populated with lions, but in general they were, for some reason, strictly nocturnal. Daytimes they inhabited the fastnesses of the mountain ranges. We never succeeded in tracing them in that large and labyrinthine country; nor at any time could we induce them to come to kills. Either their natural prey was so abundant that they did not fancy readykilled food; for, what is more likely, the cold nights prevented the odour of the carcasses from carrying far. We heard lions every night; and every morning we conscientiously turned out before daybreak to 


\section{AFRICAN CAMP FIRES}

crawl up to our bait through the wet, cold grass, but with no results. That very night we were jerked from a sound sleep by a tremendous roar almost in camp. So close was it that it seemed to each of us but just outside the tent. We came up all standing. The lion, apparently, was content with that practical joke, for he moved off quietly. Next morning we found where the tracks had led down to water, not ten yards away.

We spent the rest of that day spying on the game herds. It is fascinating work, to lie belly down on a tall ant-hill, glasses steadied by elbows, picking out the individual animals and discussing them lowvoiced with a good companion. Cuninghame and I looked over several hundred hartebeeste, trying to decide their identity. We were neither of us familiar with the animal and had only recollections of the book distinctions. Finally I picked out one that seemed to present the most marked characteristics - and missed him clean at 280 yards. Then I took three shots at 180 yards to down a second choice. The poor shooting was forgotten, however, in our determination that this was indeed Neumanii.

A vain hunt for lions occupied all the next day. The third morning Cuninghame started for the boma, leaving Billy and me to look about us as we willed. Shortly after he had departed a delegation of Masai 


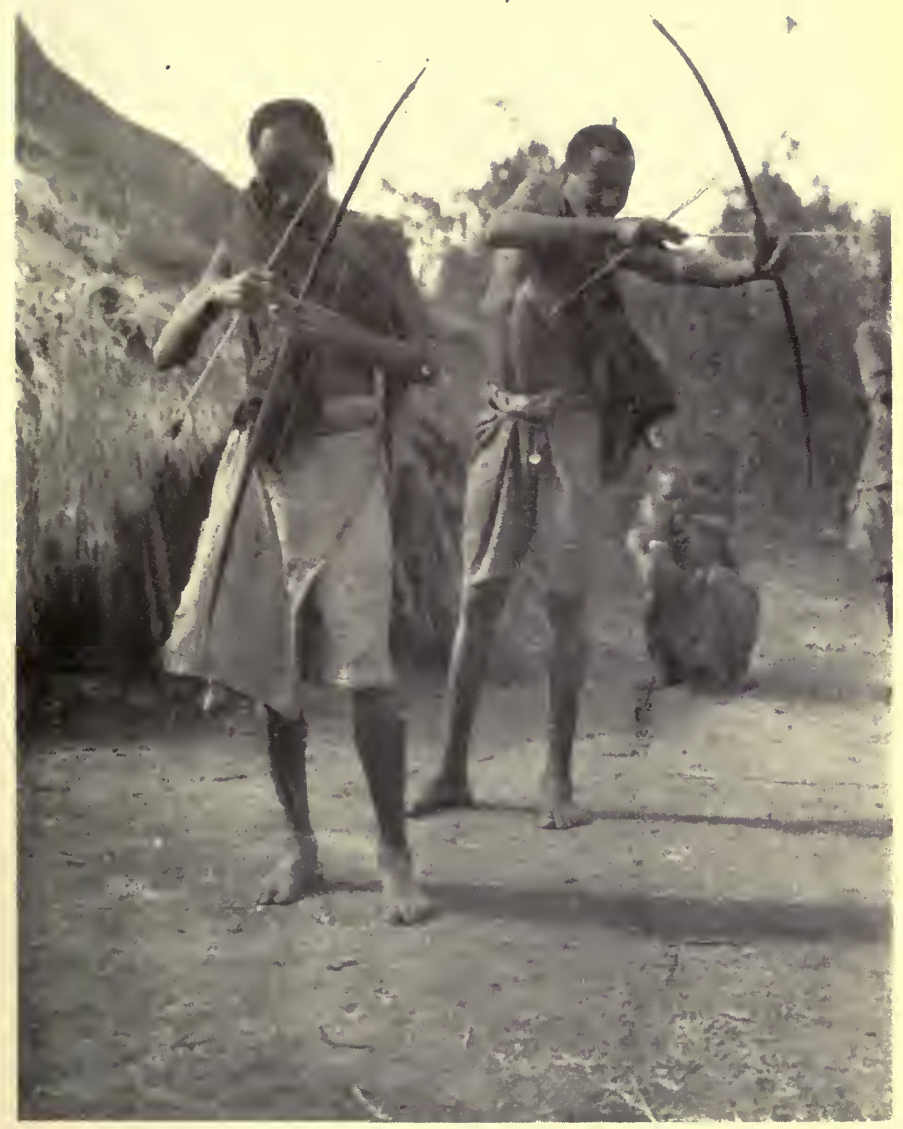

"I offered a half rupee as a prize for an archery competition" 


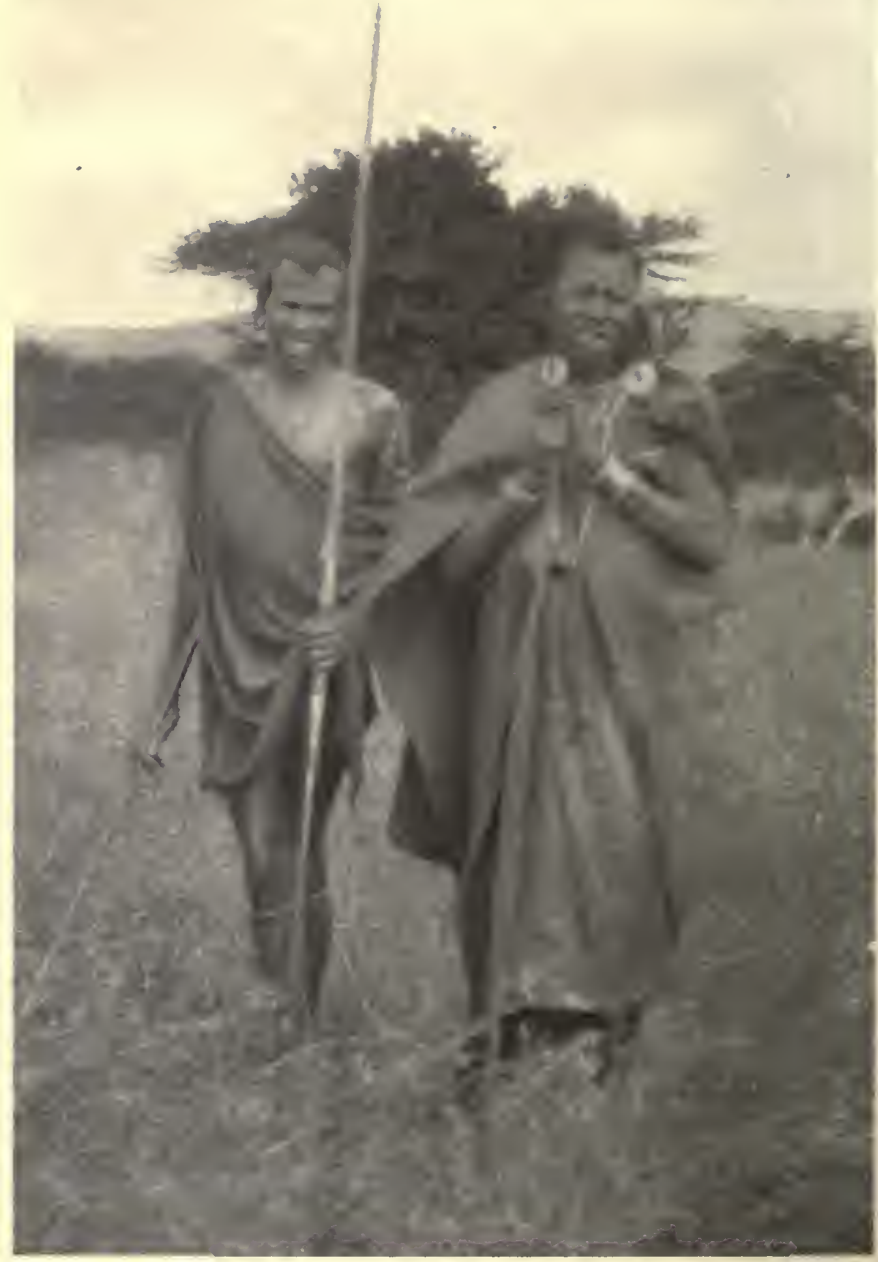

Naiokotuku and one of his sons 


\section{THE TOPI CAMP}

came in, dressed in their best, and bearing presents of milk. Leyeye was summoned as interpreter.

The Masai informed us that last night a lion had leaped the thorn walls of their boma, had pressed on through the fires, had seized a two-year-old steer, and had dragged the beast outside. Then the pursuit with spears and firebrands had become too hot for him, so that he had dropped his victim and retired. They desired (a) medicine for the steer, (b) magic to keep that lion away, (c) that I should assist them in hunting the lion down.

I questioned them closely, and soon discovered both that the lion must have been very bold, and also that he had received a pretty lively reception. Magic to keep him away seemed like a safe enough proposition; for the chances were he would keep himself away.

Therefore I filled a quart measure with clear water, passed my hand across its untroubled surface - and lo! it turned a clear bright pink!

Long-drawn exclamations of "Eigh! "Eigh!" greeted this magic, performed by means of permanganate crystals held between the fingers.

"With this bathe the wounds of your steer. Then sprinkle the remainder over your cattle. The lion will not return," said I. Then reflecting that I was to be some time in the country, and that the lion 


\section{AFRICAN CAMP FIRES}

might get over his scare, I added: "The power of this magic is three days."

They departed very much impressed. A little later Memba Sasa and I followed them. The manyatta was most picturesquely placed atop the conical hill at the foot of the valley. From its elevation we could see here and there in the distance the variegated blotches of red and white and black that represented the cattle herds. Innumerable flocks of sheep and goats, under charge of the small boys and youths, fed nearer at hand. The low smooth-plastered huts, with their abattis of thorn bush between, crowned the peak like a chaplet. Outside it sat a number of elders sunning themselves, and several smiling, good-natured young women, probably the spoiled darlings of these plutocrats. One of these damsels spoke Swahili, so we managed to exchange compliments. They told us exactly when and how the lion had gone. Three nimble old gentlemen accompanied us when we left. They were armed with spears; and they displayed the most extraordinary activity, skipping here and there across the ravines and through the brush, casting huge stones into likely cover, and generally making themselves ubiquitous. However, we did not come up with the lion.

In our clinic that evening appeared one of the 


\section{THE TOPI CAMP}

men claiming to suffer from rheumatism. I suspected him, and still suspect him, of malingering in advance in order to get out of the hard work we must soon undertake - but had no means of proving my suspicion. However, I decided to administer asperin. We possessed only the powdered form of the drug. I dumped about five grains on his tongue, and was about to proffer him the water with which to wash it down - when he inhaled sharply! I do not know the precise effect of asperin in the windpipe, but it is not pleasant. The boy thought himself bewitched. His eyes stuck out of his head; he gasped painfully; he sank to the ground; he made desperate efforts to bolt out into the brush. By main strength we restrained him, and forced him to swallow the water. Little by little he recovered. Next night I missed him from the clinic, and sent Abba Ali in search. The man assured Abba Ali most vehemently that the medicine was wonderful, that every trace of rheumatism had departed, that he never felt better in his life, and that (important point) he was perfectly able to carry a load on the morrow. 


\section{XLIV \\ THE UNKNOWN LAND}

CUNINGHAME returned the next day from V.'s, bringing more potio and some trade goods. We sent a good present back to Naiokotuku, and prepared for an early start into the new country.

We marched out the lower end of our elliptical valley toward the miniature landscape we had seen through the opening. But before we reached it we climbed sharp to the right around the end of the mountains, made our way through a low pass, and so found ourselves in a new country entirely. The smooth, undulating green-grass plains were now superseded by lava expanses grown with low bushes. It was almost exactly like the sage-brush deserts of Arizona and New Mexico; the same coarse sand and lava footing, the same deeply eroded barrancas, the same scattered round bushes dotted evenly over the scene. We saw here very little game. Across the way lay another range of low mountains clothed darkly with dull green, like the chaparral-covered coast ranges of California. In one place was a gun- 

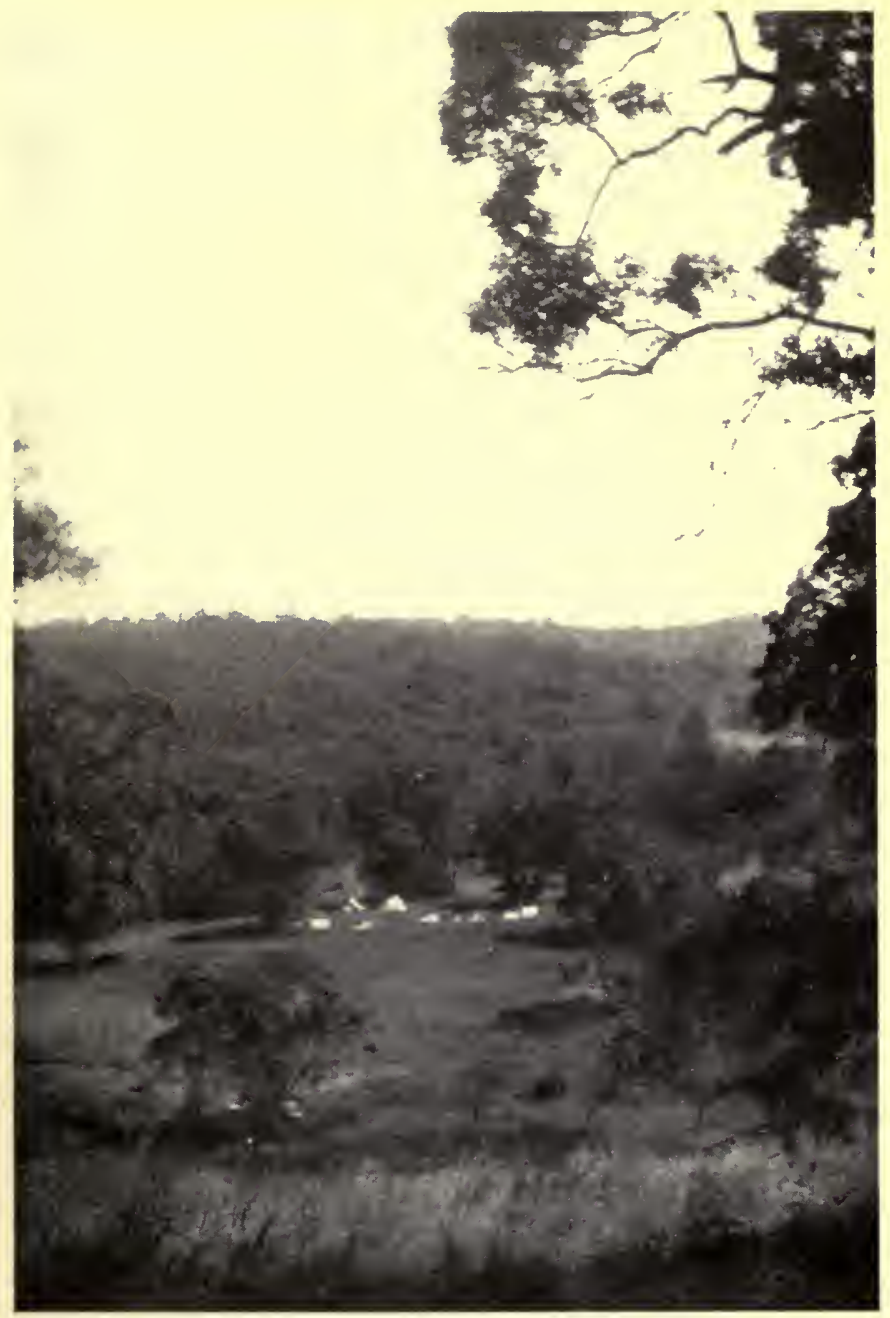

Our southernmost camp. From this point we turned back 


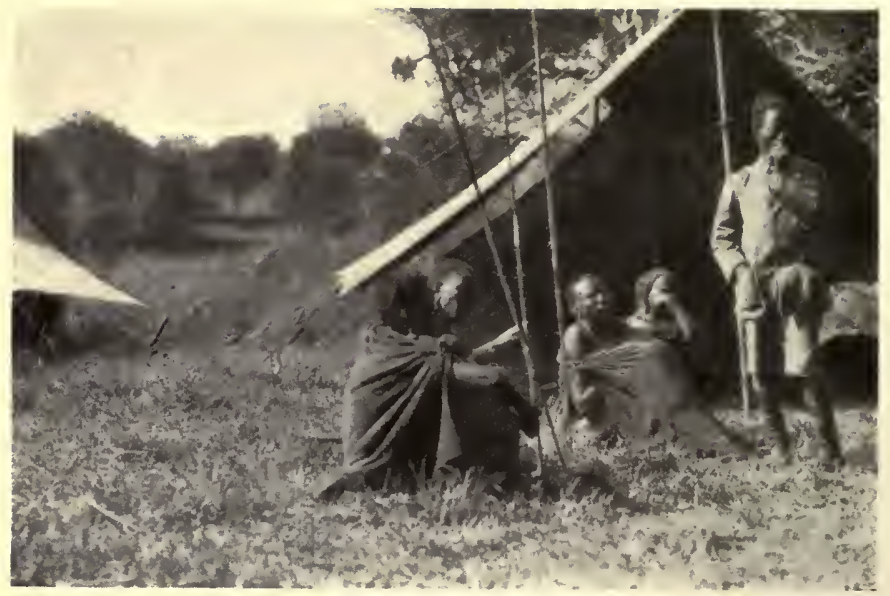

"We called the Masai and Wanderobo before us"

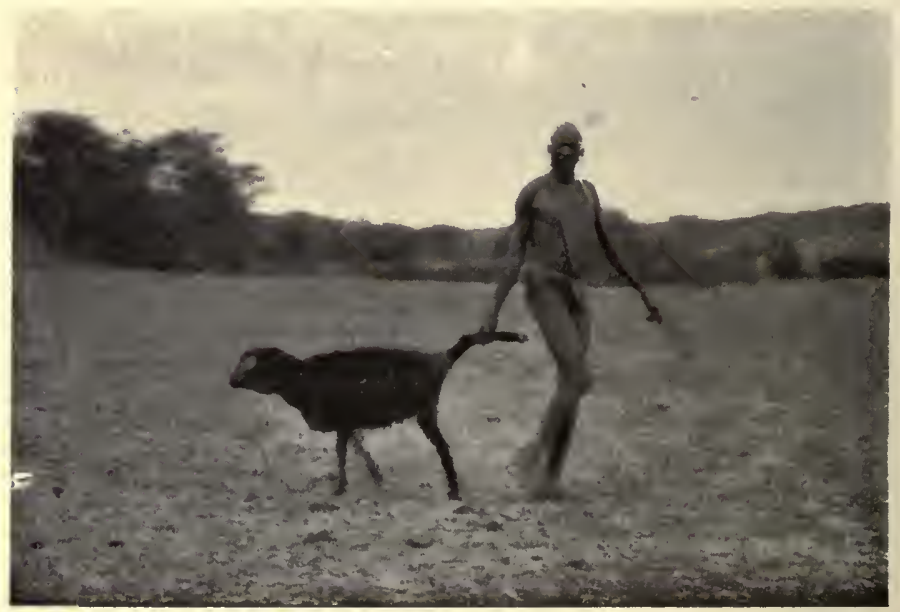

A present from Naiokotuku 


\section{THE UNKNOWN LAND}

sight pass through which we could see other distant blue mountains. We crossed the arid plain and toiled up through the notch pass.

The latter made very difficult footing indeed, for the entire surface of the ground was covered with smooth, slippery boulders and rocks of iron and quartz. What had so smocched them I do not know; for they seemed to be ill-placed for water erosion. The boys with their packs atop found this hard going; and we ourselves slipped and slid and bumped in spite of our caution.

Once through the pass we found ourselves overlooking a wide prospect of undulating thorn scrub from which rose occasional bushy hills, solitary buttes, and bold cliffs. It was a thick-looking country to make a way through.

Nevertheless somewhere here dwelt the kudu, so in we plunged. The rest of the day - and of days to follow - we spent in picking a way through the thorn scrub and over loose rocks and shifting stones. A stream bed contained an occasional water hole. Tall aloes were ablaze with red flowers. The country looked arid, the air felt dry, the atmosphere was so clear that a day's journey became - visually - but the matter of a few hours. Only rarely did we enjoy a few moments of open travel. Most of the time the thorns caught at us. In the mountain 


\section{AFRICAN CAMP FIRES}

passes were sometimes broad trails of game or of the Masai cattle. The country was harsh and dry and beautiful with the grays and dull greens of arid-land brush, or with the soft atmospheric tints of aridland distances. Game was fairly common, but rather difficult to find. There were many buffalo, a very few zebra, leopards, hyenas, plenty of impalla, some sing-sing, a few eland, abundant warthog, Thompson's gazelle, and duiker. We never lacked for meat when we dared shoot it, but we were after nobler game. The sheep given us by Naiokotuku followed along under charge of the syces.

When we should have run quite out of meat, we intended to eat them. We delayed too long, however. One evening the fool boy tied them to a thorn bush; one of them pulled back, the thorns bit, and both broke loose and departed into the darkness. Of course everybody pursued, but we could not recapture them. Ten minutes later the hyenas broke into the most unholy laughter. We could not blame them; the joke was certainly on us.

In passing, the cachinnations of the laughing hyena are rather a series of high-voiced, self-conscious titters than laughter. They sound like the stage idea of a lot of silly and rather embarrassed old maids who have been accused by some rude man of "taking notice." This call is rarely used; indeed, 


\section{THE UNKNOWN LAND}

I never heard it but the once. The usual note is a sort of moaning howl, impossible to describe but easy to recognize.

Thus we penetrated gradually deeper and deeper into this wild country; through low mountains, over bush-clad plains, into thorn jungles, down wide valleys, over hill-divided plateaus. Late in the afternoon we would make camp. Sometimes we had good water; more often not. In the evening the throb of distant drums and snatches of intermittent wailing song rose and fell with the little night breezes. 


\section{XLV}

\section{THE ROAN}

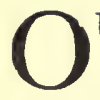

UR last camp, before turning back, we pitched about two o'clock of one afternoon. Up to this time we had marched steadily down wide valleys, around the end of mountain ranges, moving from one room to the other of this hill-divided plateau. At last we ended on a slope that descended gently to water. It was grown sparingly with thorn trees, among which we raised our tents. Over against us, and across several low swells of grass and scrubgrown hills, was a range of mountains. Here, Mavrouki claimed, dwelt roan antelope.

We settled down quite happily. The country round about was full of game; the weather was cool, the wide swoops of country, the upward fling of mountains and buttes were much like some parts of our great West. Almost every evening the thunder storms made gorgeous piled effects in the distance. At night the lions and hyenas roared or howled, and some of the tiny fever owls impudently answered them back. 


\section{THE ROAN}

Various adventures came our way, some of which have been elsewhere narrated. Here we killed the very big buffalo that nearly got Billy.* In addition we collected two more specimens of the Neuman's hartebeeste, and two Chanler's reed buck.

But Mavrouki's glowing predictions as to roan were hardly borne out by facts. According to him the mountains simply swarmed with them - he had seen thirty-five in one day, etc. Of course we had discounted this, but some old tracks had to a certain extent borne out his statement.

Lunch time one day, however, found us on top of the highest ridge. Here we hunted up a bit of shade, and spent two hours out of the noon sun. While we lay there the sky slowly overcast, so that when we aroused ourselves to go on, the dazzling light had softened. As time was getting short, we decided to separate. Memba Sasa and Mavrouki were to go in one direction, while Cuninghame, Kongoni and I took the other. Before we started I remarked that I was offering two rupees for the capture of a roan.

We had not gone ten minutes when Kongoni turned his head cautiously and grinned back at us.

"My rupees," said he.

*" The Land of Footprints." 


\section{AFRICAN CAMP FIRES}

A fine buck roan stood motionless beneath a tree in the valley below us. He was on the other side of the stream jungle, and nearly a mile away. While we watched him, he lay down.

Our task now was to gain the shelter of the streamjungle below without being seen, to slip along it until opposite the roan, and then to penetrate the river jungle near enough to get a shot. The first part of this contract seemed to us the most difficult, for we were forced to descend the face of the hill, like flies crawling down a blackboard, plain for him to see.

We slid cautiously from bush to bush; we moved by imperceptible inches across the too numerous open paces. About halfway down we were arrested by a violent snort ahead. Fifteen or twenty zebra nooning in the brush where no zebra were supposed to be, clattered down the hill like an avalanche. We froze where we were. The beasts ran fifty yards, then wheeled, and stared back up the hill, trying to make us out. For twenty minutes all parties to the transaction remained stock still, the zebra staring, we hoping fervently they would decide to go down the valley and not up it, the roan dozing under his distant tree.

By luck our hopes were fulfilled. The zebra turned down stream, walking sedately away in 


\section{THE ROAN}

single file. When we were certain they had all quite gone, we resumed our painful decsent.

At length we dropped below the screen of trees, and could stand upright and straighten the kinks out of our backs. But now a new complication arose. The wind, which had been the very basis of our calculations, commenced to chop and veer. Here it blew from one quarter, up there on the side hill from another, and through the bushes in quite another direction still. Then without warning they would all shift about. We watched the tops of the grasses through our binoculars, hoping to read some logic into the condition. It was now four o'clock - our stalk had thus far consumed two hours - and the roan must soon begin to feed. If we were going to do anything, we must do it soon.

Therefore we crept through a very spiky, noisy jungle to its other edge, sneaked along the edge until we could make out the tree, and raised ourselves for a look. Through the glass I could just make out the roan's face stripe. He was still there!

Quite encouraged I instantly dropped down and crawled to within range. When again I raised my head the roan had disappeared. One of those aggravating little side puffs of breeze had destroyed our two hours' work.

The outlook was not particularly encouraging. 


\section{AFRICAN CAMP FIRES}

We had no means of telling how far the animal would go, nor into what sort of country; and the hour was well advanced toward sunset. However, we took up the track and proceeded to follow it as well as we could. That was not easy, for the ground was hard and stony. Suddenly Cuninghame threw himself flat. Of course we followed his example. To us he whispered that he thought he had caught a glimpse of the animal through an opening and across the stream bed. We stalked carefully; and found ourselves in the middle of a small herd of topis, one of which, half concealed in the brush, had deceived Cuninghame. This consumed valuable time. When again we had picked up the spoor it was agreed that I was to still-hunt ahead as rapidly as I could, while Cuninghame and Kongoni would puzzle out the tracks as far as possible before dark.

Therefore I climbed the little rocky ridge on our left, and walked along near its crest, keeping a sharp lookout over the valley below; much as one would hunt August bucks in California. After two or three hundred yards I chanced on a short strip of soft earth in which the fresh tracks of the roan going up hill were clearly imprinted. I could not without making too much noise inform the others that $I$ had cut in ahead of them; so I followed the tracks as cautiously and quietly as I could. On the 


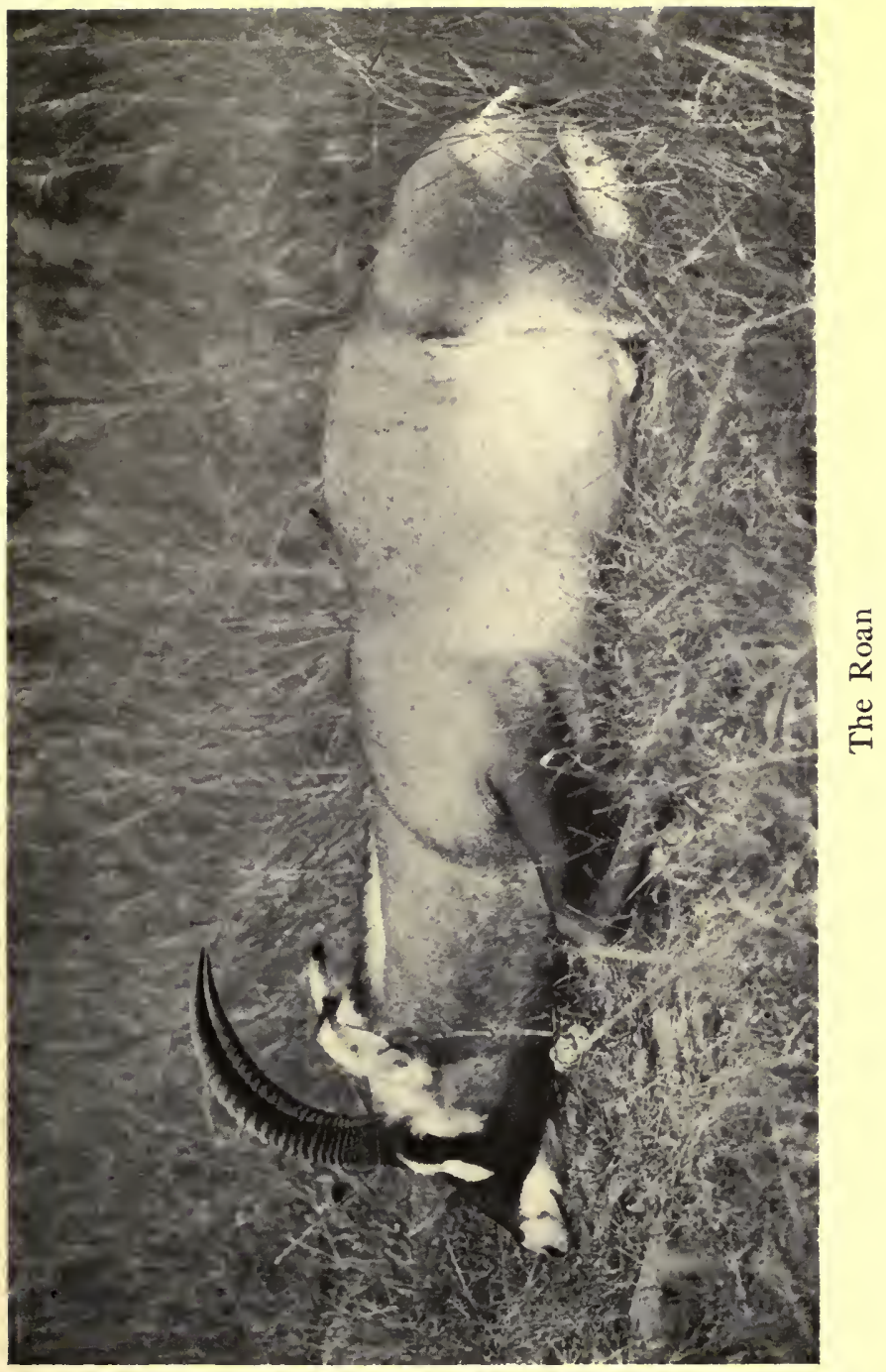




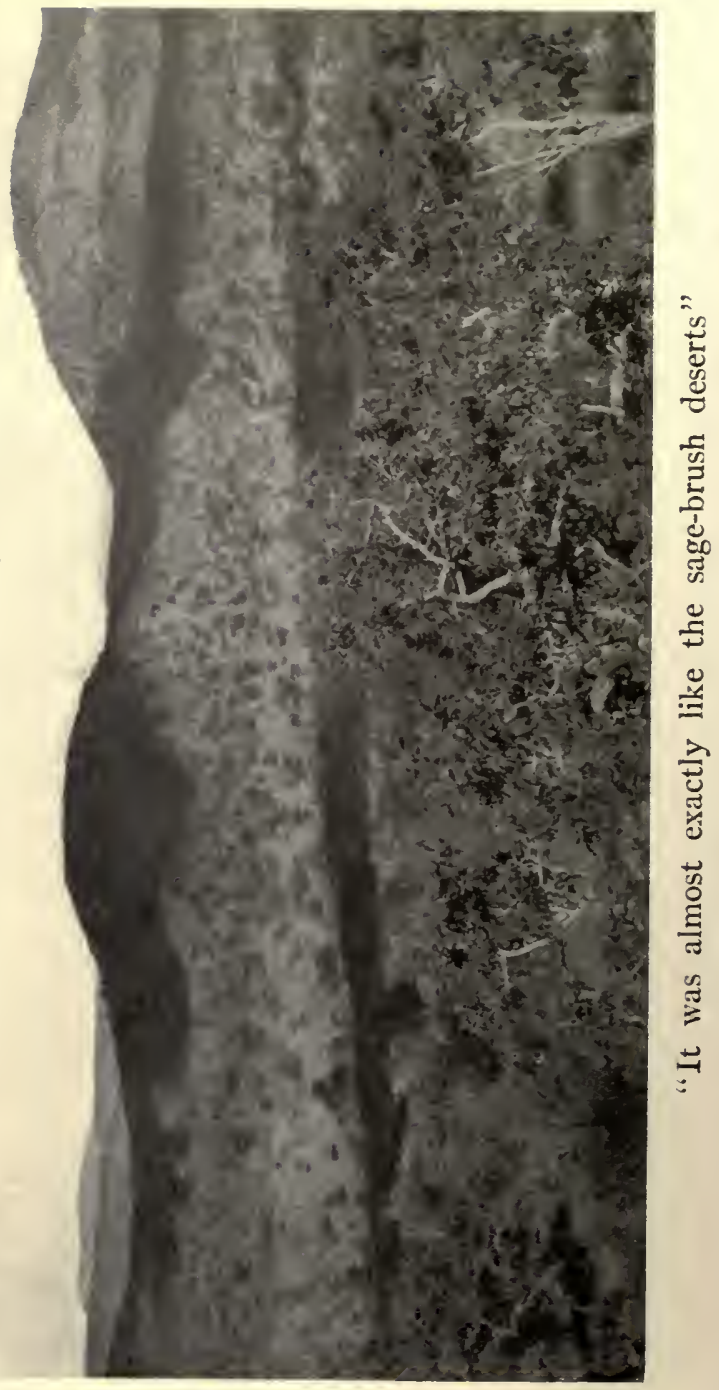




\section{THE ROAN}

very top of the hill the roan leaped from cover fifty yards away, and with a clatter of rocks dashed off down the ridge. The grass was very high, and I could see only his head and horns, but I dropped the front sight six inches and let drive at a guess. The guess happened to be a good one, for he turned a summersault seventy two yards away.

Cuninghame and Kongoni came up. The sun had just set. In fifteen minutes it would be pitch dark. We despatched Kongoni for help and lanterns; and turned to on the job of building a signal fire and skinning the trophy.

The reason for our strangely chopping wind now became apparent. From our elevation we could see piled thunder clouds looming up from the west. They were spreading upward and outward in the swift, rushing manner of tropic storms; and I saw I must hustle if I was to get my fire going at all. The first little blaze was easy; and after that I had to pile on quantities of any wood I could lay my hands to. The deluge blotted out every vestige of daylight and nearly drowned out my fire. I had started to help Cuninghame with the roan, but soon found that I had my own job cut out for me, and so went back to nursing my blaze. The water descended in sheets. We were immediately soaked through, and very cold. The surface of the ground was steep and covered 


\section{AFRICAN CAMP FIRES}

with loose round rocks; and in my continuous trips for firewood I stumbled and slipped and ran into thorns miserably.*

After a long interval of this the lanterns came bobbing through the darkness, and a few moments later the dim light revealed the shining, rain-soaked faces of our men.

We wasted no time in the distributions of burdens. Cuninghame with one of the lanterns brought up the rear, while I with the other went on ahead.

Now as Kongoni had but this minute completed the round trip to camp we concluded that he would be the best one to give us a lead. This was a mistake. He took us out of the hills well enough, and a good job that was, for we could not see the length of our arms into the thick, rainy blackness, and we had to go entirely by the slants of the country. But once in the more open, sloping country, with its innumerable bushy or wooded ravines, he began to stray. I felt this from the first; but Kongoni insisted strongly he was right, and in the rain and darkness we had no way of proving him wrong. In fact I had no reason for thinking him wrong, I only felt it. This sense of direction is apparently a fifth wheel or extra adjustment some people happen to possess. It has

\footnotetext{
* Six months after I had reached home one of these thorns worked its way out of the calf of my leg.
} 


\section{THE ROAN}

nothing to do with acquired knowledge, as is very well proved by the fact that in my own case it acts only as long as I do not think about it. As soon as I begin consciously to consider the matter I am likely to go wrong. Thus many, many times I have backtracked in the dark over ground I had traversed but once before, and have caught myself turning out for bushes or trees I could not see, but which my subconscious memory recalled. This would happen only when I would think of something beside the way home. As soon as I took charge, I groped as badly as the next man. It is a curious, and sometimes valuable extra; but by no means to be depended upon.

Now, however, as I was following Kongoni, this faculty had full play; and it assured me vehemently that we were wrong. I called Cuninghame up from the rear for consultation. Kongoni was very positive he was right, but as we had now been walking over an hour, and camp should not have been more than three miles from where we had killed the roan, we were inclined toward my instinct. So we took the compass direction, in order to assure consistency at least, and struck off at full right angles to the left.

So we tramped for a long time. Every few moments Kongoni would want another look at that compass. It happened that we were now going due 


\section{AFRICAN CAMP FIRES}

north; and his notion was that the needle pointed the way to camp. We profoundly hoped that his faith in white man's magic would not be shattered. At the end of an hour the rain let up, and it cleared sufficiently to disclose some of the mountain outlines. They convinced us that we were in the main right; though just where, to the north, camp now lay was beyond our power to determine. Kongoni's detour had been rather indeterminate in direction and distance.

The country now became very rough, in a small way. The feeble light of our leading lantern revealed only ghosts and phantoms and looming, warning suggestions of things which the shadows confused and shifted. Heavily laden men would have found it difficult travelling by prosaic daylight; but now, with the added impossibility of picking a route ahead, we found ourselves in all sorts of trouble. Many times we had to back out and try again. The ghostly flickering tree shapes against the fathomless black offered us apparently endless aisles that nevertheless closed before us like the doors of a trap when we attempted to enter them.

We kept doggedly to the same general northerly direction. When you are lost, nothing is more foolish than to make up your mind hastily and without due reflection; and nothing is more foolish 


\section{THE ROAN}

than to change your mind once you have made it up. That way vacillation, confusion, and disaster lie. Should you decide, after due consideration of all the elements of the problem, that you should go east; then east you go, and nothing must turn you. You may get to the Atlantic Ocean if nothing else. And if you begin to modify your original plan, then you begin to circle. Believe me; I know.

Kongoni was plainly skeptical, and said so until I shut him up with some rather peremptory sarcasm. The bearers, who had to stumble in the dark under heavy burdens, were good-natured and joking. This we appreciated. One can never tell whether or not he is popular with a native until he and the native are caught in a dangerous or disagreeable fix.

We walked two hours as in a treadmill. Then that invaluable, though erratic, sixth sense of mine awoke. I stopped short.

"I believe we've come far enough," I shouted back to Cuninghame and fired my rifle.

We received an almost immediate answer from a short distance to the left. Not over two hundred yards in that direction we met our camp men bearing torches, and so were escorted in triumph after a sixteen-hour day. 


\section{XLVI}

\section{THE GREATER KUDU}

TEXT morning, in a joking manner, I tried to 1 impress Kongoni with a sense of delinquency in not knowing better his directions, especially as he had twice traversed the route. He declined to be impressed.

"It is not the business of man to walk at night," he replied with dignity.

And when you stop to think of it, it certainly is not - in Africa.

At this camp we lingered several days. The great prize of our journeying still lacked, and, to tell the truth, we had about given up hope if not our efforts. Almost we had begun to believe our friends in Nariobi who had scoffed at the uselessness of our quest. Always we conscientiously looked over good kudu country, hundreds of miles of it, and always with the same lack of result, or even of encouragement. Other game we saw in plenty, of a dozen different varieties large and small; but our five weeks' search had thus far yielded us only the sight of the 


\section{THE GREATER KUDU}

same old, old sign, made many months before. If you had stood with us atop one of the mountains, and with us had looked abroad on the countless leagues of rolling, brush-clothed land, undulating away in all directions over a far horizon, you must with us have estimated as very slight the chances of happening on the exact pin point where the kudu at that moment happened to be feeding. For the beast is shy, it inhabits the densest, closest mountain cover, it possesses the keen eyesight and sense of smell of the bush-dwelling deer and antelope, and more than the average sense of hearing. There are very few of him. But the chief discouragement is that arising from his roaming tendencies. Other rare animals are apt to "use" about one locality, so that once the hunter finds tracks, new or old, his game is one of patient, skillful search. The greater kudu, however seems in this country at least to be a wanderer. $\mathrm{He}$ is here to-day, and gone to-morrow. Systematic search seems as foolish as in the case of the proverbial needle in the haystack. The only method is to shift constantly, and trust to luck. One cannot catch fish with the fly in the book, but he has at least a chance if he keeps it on the water.

Mavrouki was the only one among us who had the living faith that comes from having seen the animal in the flesh. That is a curious bit of hunter 


\section{AFRICAN CAMP FIRES}

psychology. When a man is out after a species new to him, it is only by the utmost stretch of the imagination that he is able to realize that such an animal can exist at all. He cannot prefigure it, somehow. He generally exaggerates to himself the difficulty of making it out, of approaching it, of getting his shot; until at last, if he happens to have hunted some time in vain, the beast becomes almost mythical and unbelievable. Once he has seen the animal, whether he gets a shot or not, all this vanishes. The strain on faith relaxes. He knows what to look for, and what to expect; and even if he sees no other specimen for a month, he nevertheless goes about the business with a certain confidence.

One afternoon we had been hunting carefully certain low mountains, and were headed for camp, walking rather carelessly along the bed of a narrow, open valley below the bush-covered side hills. The sun had disappeared behind the ranges, and the dusk of evening was just beginning to rise like a mist from the deeps of the cañons. We had ceased hunting it was time to hurry home - and happened not to be talking only because we were tired. By sheerest idle luck I chanced to look up to the densely covered face of the mountain. Across a single tiny opening in the tall brush five or six hundred yards away I caught a movement. Still idly I lifted my glasses 


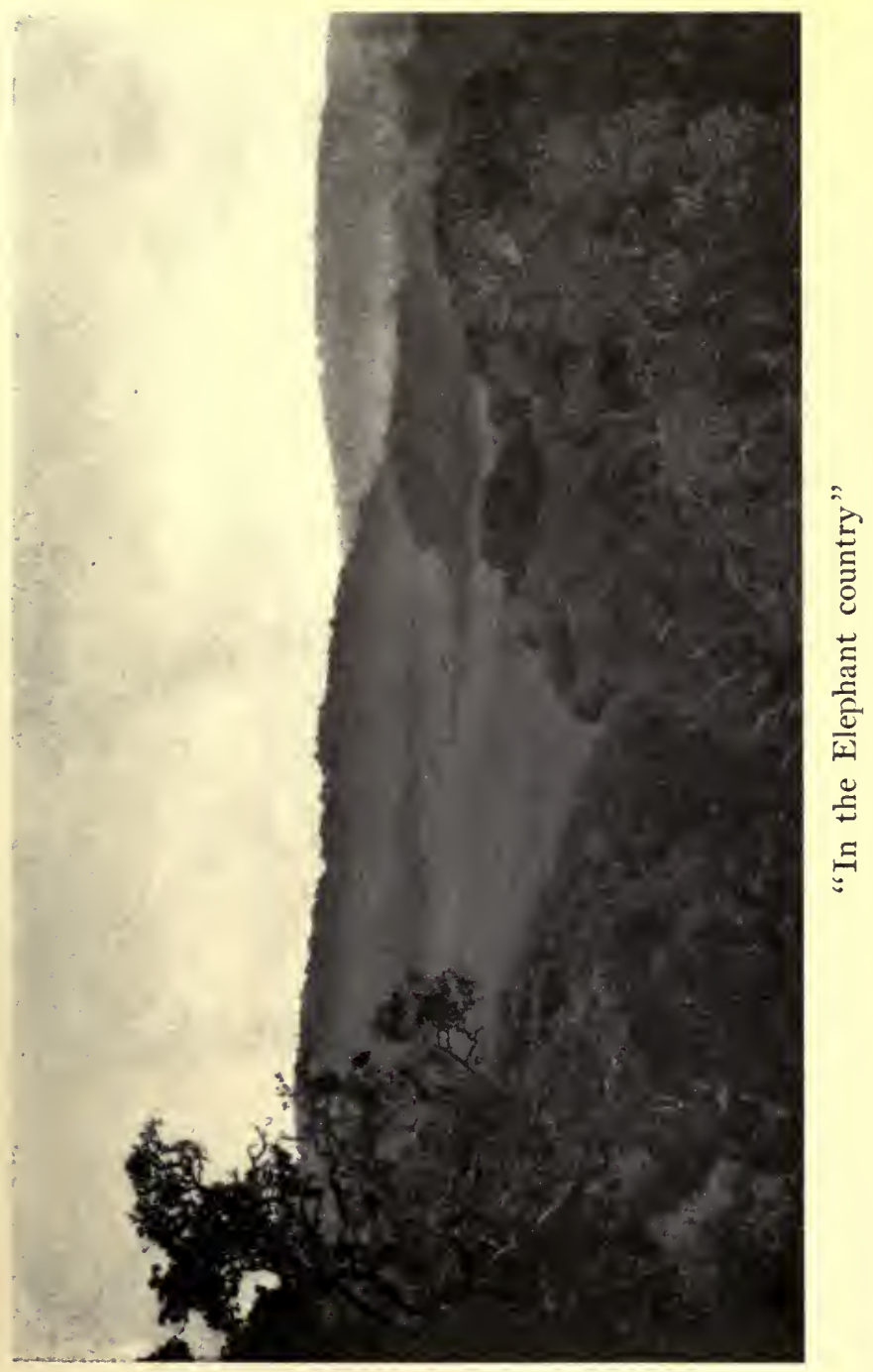




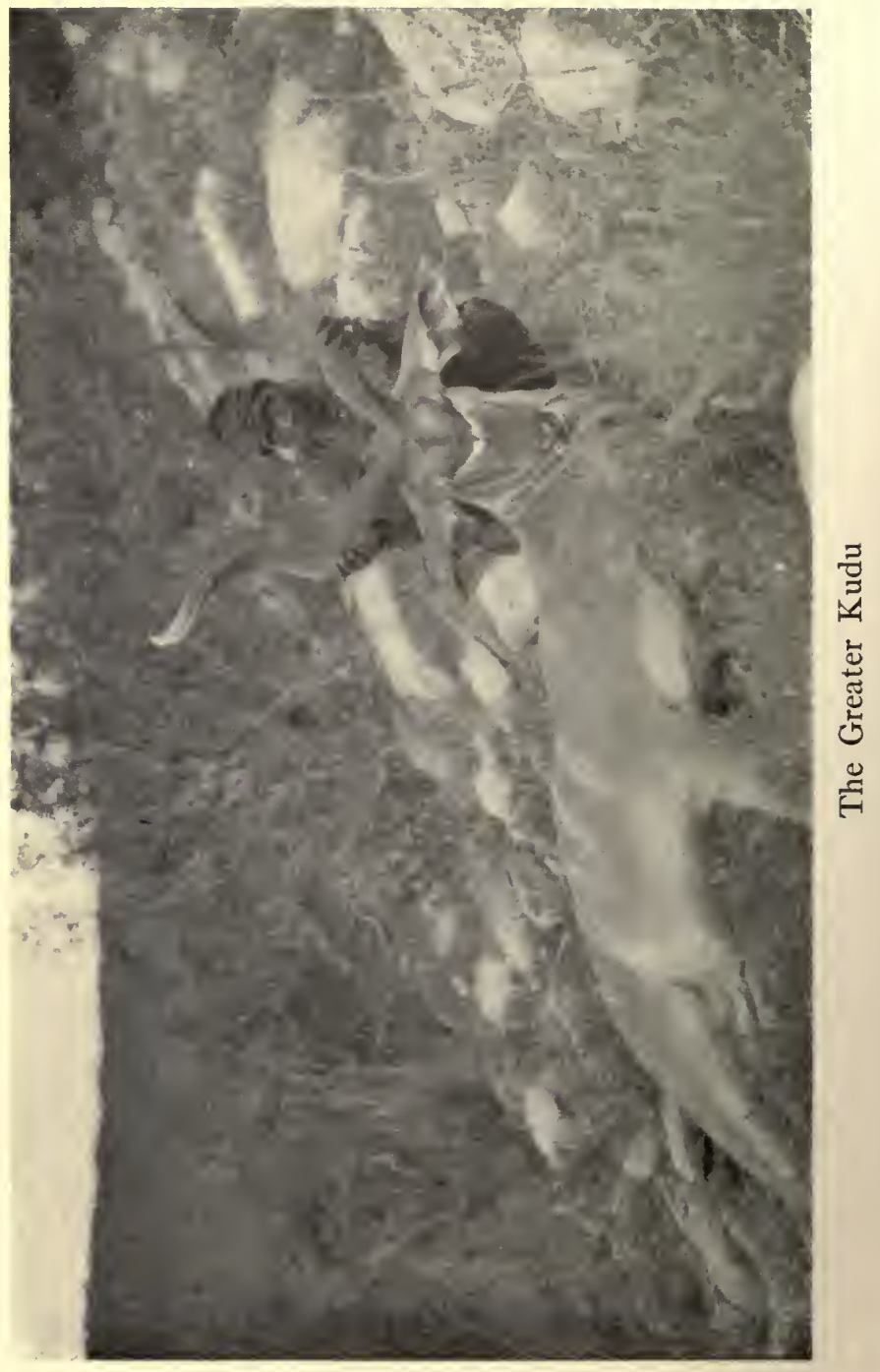




\section{THE GREATER KUDU}

for a look at what I thought would prove the usual impalla or sing-sing, and was just in time to catch the spirals of a magnificent set of horns. It was the greater kudu at last!

I gave a little cluck of caution; and instantly, without question, after the African fashion, the three men ahead of me sank to the ground. Cuninghame looked at me inquiringly. I motioned with my eyes. He raised his glasses for one look.

"That's the fellow," he said quietly.

The kudu, as though he had merely stepped into the opening to give us a sight of him, melted into the brush.

It was magnificent and exciting to have seen this wonderful beast after so long a quest, but by the same token it was not very encouraging for all that. If we had had all the daylight we needed, and unlimited time, it would have been quite a feat to stalk the wary beast in that thick, noisy cover. Now it was almost dark, and would be quite dark within the half hour. The kudu had moved out of sight. Whether he had gone on some distance, or whether he still lingered near the edge of the tiny opening was another matter to be determined, and to be determined quickly.

Leaving, Kongoni and Mavrouki, Cuninghame and I wriggled pantingly up the hill, as fast and at the 


\section{AFRICAN CAMP FIRES}

same time as cautiously as we could. At the edge of the opening we came to a halt, belly down, and began eagerly to scrutinize the brush across the way. If the kudu still lingered we had to find it out before we ventured out of cover to take up his trail. Inch by inch we scrutinized every possible concealment. Finally Cuninghame breathed sharp with satisfaction. He had caught sight of the tip of one horn. With some difficulty he indicated to me where. After staring long enough, we could dimly make out the kudu himself browsing, from the tender branch-ends.

All we could do was to lie low. If the kudu fed on out of sight into the cover, we could not possibly get a shot; if he should happen again to cross the opening, we would get a good shot. No one but a hunter can understand the panting, dry-mouthed excitement of those minutes; five weeks' hard work hung in the balance. The kudu did neither of these things; he ceased browsing, took three steps forward, and stood.

The game seemed blocked. The kudu had evidently settled down for a snooze; it was impossible, in the situation, to shorten the distance without being discovered; the daylight was almost gone; we could make out no trace of him except through our glasses. Look as hard as we could, we could see nothing with the naked eye. Unless something happened within 


\section{THE GREATER KUDU}

the next two minutes we would bring nothing into camp but the memory of a magnificent beast. And next day he would probably be inextricably lost in the wilderness of mountains.*

It was a time for desperate measures, and, to Cuninghame's evident anxiety, I took them. Through the glasses the mane of the kudu showed as a dim gray streak. Carefully I picked out two twigs on a bush fifteen feet from me and a tuft of grass ten yards on, all of which were in line with where the shoulder of the kudu ought to be. Then I lowered my glasses. The gray streak of the kudu's mane had disappeared in the blending twilight; but I could still see the tips of the twigs and the tuft of grass. Very carefully I aligned the sights with these; and, with a silent prayer to the Red Gods, loosed the bullet into the darkness.

At the crack of the rifle the kudu leaped into plain sight.

"Hit!" rasped Cuninghame in great excitement.

I did not wait to verify this, but fired four times more as fast as I could work the bolt. Three of the bullets told. At the last shot he crumpled and came rolling down the slope. We both raised a wild whoop of triumph, which was answered at once by the expectant gunbearers below.

The finest trophy in Africa was ours!

${ }^{*}$ Trailing for any distance was impossible on account of the stony soil. 


\section{XLVII}

\section{THE MAGIC PORTALS CLOSE}

TT seemed hopeless to try for a picture. Never1 theless I opened wide my lens, steadied the camera, and gave it a half second. The result was fairly good. So much for a high grade lens. We sent Kongoni in to camp for help, and ourselves proceeded to build up the usual fire for signal and for protection against wild beasts. Then we sat down to enjoy the evening, while Mavrouki skinned the kudu.

We looked abroad over a wide stretch of country. Successive low ridges crossed our front, each of a different shade of slate gray from its neighbours; and a gray half-luminous mist filled the valley between them. The edge of the world was thrown sharp against burnished copper. After a time the moon rose.

Memba Sasa arrived before the lanterns, out of breath, his face streaming with perspiration. Poor Memba Sasa! this was almost the only day he had not followed close at my heels, and on this day we had 


\section{THE MAGIC PORTALS CLOSE}

captured the Great Prize! No thought of that seemed to affect the heartiness of his joy. He rushed up to shake both my hands; he examined the kudu with an attention that was held only by great restraint; he let go that restraint to shake me again enthusiastically by the hands. After him, up the hill, bobbed slowly the lanterns. The smiling bearers shouldered the trophy and the meat; and we stumbled home through the half shadows and the opalescences of the moonlight.

Our task in this part of the country was now finished. We set out on the return journey. The weather changed. A beautiful, bright-copper sunset was followed by a drizzle. By morning this had turned into a heavy rain. We left the topi camp to which we had by now returned, cold and miserable. Cuninghame and I had contributed our waterproofs to protect the precious trophies; and we were speedily wet through. The grass was long. This was no warm and grateful tropical rain; but a driving, chilling storm straight out from the high mountains.

We marched up the long plain, we turned to the left around the base of the ranges, we mounted the narrow grass valley, we entered the forest - the dark, dripping, and unfriendly forest. Over the edge we dropped and clambered down through the hanging vines and the sombre trees. By and by we 


\section{AFRICAN CAMP FIRES}

emerged on the open plains below, the plains on the hither side of the Naróssara, the Africa we had known so long. The rain ceased. It was almost as though a magic portal had clicked after us. Behind it lay the wonderful secret upper country of the unknown. 


\section{XLVIII \\ THE LAST TREK}

GOME weeks later we camped high on the slopes $\mathcal{N}$ of Suswa, the great mountain of the Rift Valley, only one day's march from the railroad. After the capture of the kudu Africa still held for us various adventures - a buffalo, a go of fever, and the like - but the culmination had been reached. We had lingered until the latest moment, reluctant to go. Now in the gray dawn we were filing down the slopes of the mountains for the last trek. A low, flowing mist marked the distant Kedong; the flames of an African sunrise were revelling in the eastern skies. All our old friends seemed to be bidding us good-bye. Around the shoulder of the mountains a lion roared, rumble upon rumble. Two hyenas leaped from the grass, ran fifty yards, and turned to look at us.

"Good-bye, simba! good-bye, fice!" we cried to them sadly.

A little farther we saw zebra, and the hartebeeste, and the gazelles. One by one appeared and disap- 


\section{AFRICAN CAMP FIRES}

peared again the beasts with which we had grown so familiar during our long months in the jungle. So remarkable was the number of species that we both began to comment upon the fact, to greet the animals, to say them farewell, as though they were reporting orderly from the jungle to bid us godspeed. Half in earnest we waved our hands to them and shouted our greetings to them in the native - punda milia, kongoni, pa-a, fice, m'pofu, twiga, simba, $n$ 'grooui, and the rest. Before our eyes the misty ranges hardened and stiffened under the fierce sun. Our men marched steadily, cheerfully, beating their loads in rhythm with their safari sticks, crooning under their breaths and occasionally breaking into full-voiced chant. They were glad to be back from the long safari, back from across the Thirst, from the high, cold country, from the dangers and discomforts of the unknown. We rode a little wistfully, for these great plains and mysterious jungles, these populous, dangerous, many-voiced nights, these flaming, splendid dawnings and day-falls, these fierce, shimmering noons we were to know no more.

Two days we had in Nairobi before going to the coast. There we paid off and dismissed our men, giving them presents according to the length and faithfulness of their service. They took them and departed, eagerly, as was natural, to the families and 


\section{THE LAST TREK}

the pleasures from which they had been so long separated. Mohamet said good-bye, and went, and was sorry; Kongoni departed, after many, and sincere protestions; quiet little Mavrouki came back three times to shake hands again, and disappeared reluctantly - but disappeared; Leyeye went; Abba Ali followed the service of his master, Cuninghame; "Timothy" received his present -in which he was disappointed - and departed with salaams. Only Memba Sasa remained. I paid him for his long service, and I gave him many and rich presents, and bade farewell to him with genuine regret and affection.

Memba Sasa had wives and a farm near town, neither of which possessions he had seen for a very long while. Nevertheless he made no move to see them. When our final interview had terminated with the usual "bass!" (It is finished) he shook hands once more and withdrew, but only to take his position across the street. There he squatted on his heels, fixed his eyes upon me, and remained. I went downtown on business. Happening to glance through the office window I caught sight of Memba Sasa, again across the street, squatted on his heels, his gaze fixed unwaveringly on my face. So it was for two days. When I tried to approach him, he glided away, so that I got no further speech with him; 


\section{AFRICAN CAMP FIRES}

but always, quietly and unobtrusively, he returned to where he could see me plainly. He considered that our interview had terminated our official relations, but he wanted to see the last of the bwana with whom he had journeyed so far.

One makes many acquaintances as one knocks about the world; and once in a great many moons one finds a friend - a man the mere fact of whose existence one is glad to realize, whether one ever sees him again or not. These are not many, and they are of various degree. Among them I am glad to number this fierce savage. He was efficient, selfrespecting, brave, staunch, and loyal with a great loyalty. I do not think I can better end this book than by this tribute to a man whose opportunities were not many, but whose soul was great 


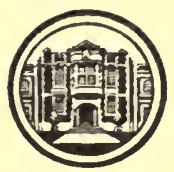

The Country Life Press Garden City, N. Y. 




\section{University of California}

SOUTHERN REGIONAL LIBRARY FACILITY

405 Hilgard Avenue, Los Angeles, CA 90024-1388

Return this material to the library

from which it was borrowed. 

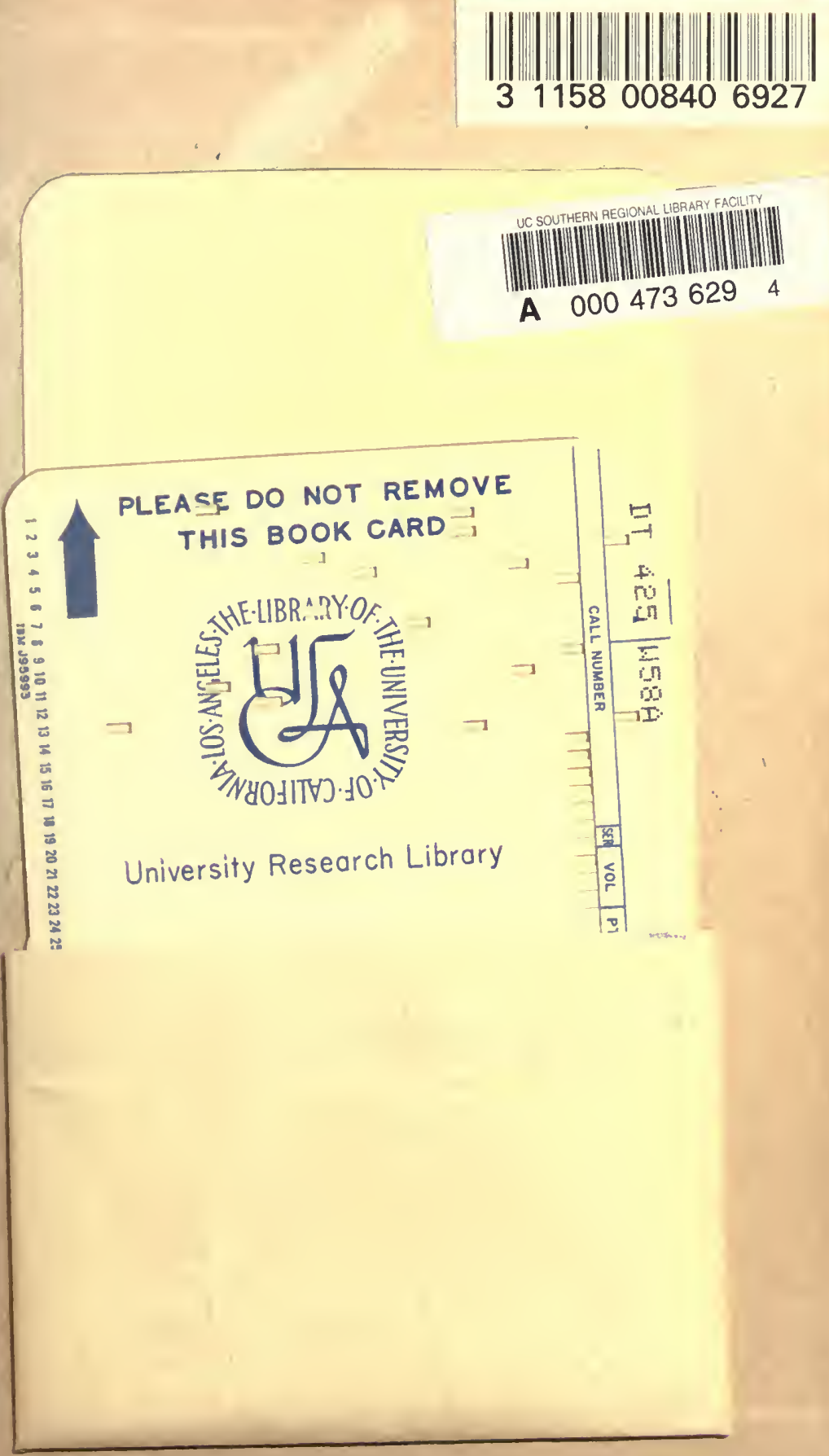
$\operatorname{sen} x$

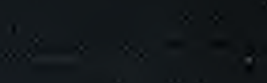

.

4

$8+\infty 8$

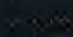

$\cos x=8$

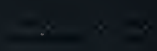

$-78$

$+\infty x+28$ 